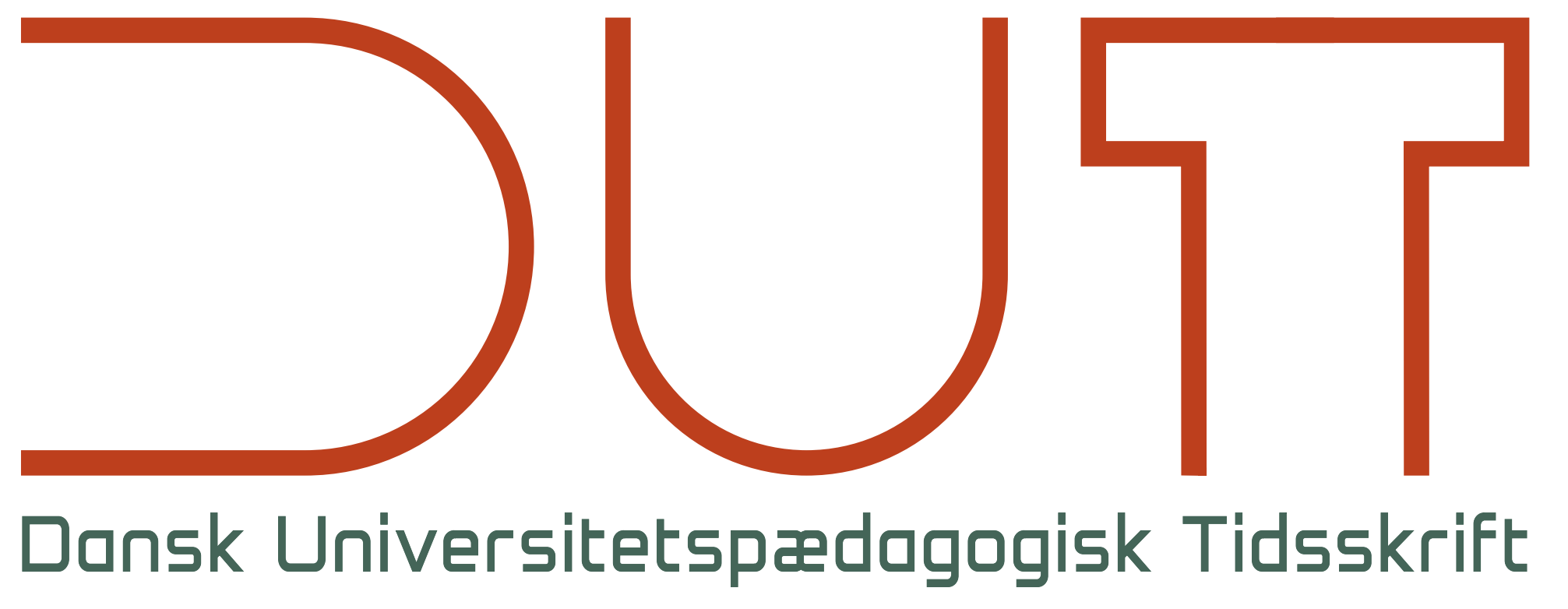

Kvalitet i

universitetsundervisningen

- forskningsbasering,

praksisrelevans og

strategisk indsats 


\section{Indhold}

At synliggøre, hvordan læring er blevet gjort mulig

Rie Troelsen

Tilstræbt og realiseret tværfaglighed i universitetsundervisning

Katrine Lindvig, Lars Ulriksen

Sker der noget med læringsudbyttet, når undervisningssproget skiftes?

14

Camilla Falk Rønne Nissen, Lars UIriksen

Universitetsuddannelsens relevans i samfundsvidenskabelige studerendes perspektiv

Laura Pérez Skardhamar, Charlotte Baarts

eller akademisk dannelse?

Nikolaj Stegeager

Fire trin mod udbytterige studenteroplæg - hvordan præsentationer i undervisningen højner fagligheden og bliver en positiv oplevelse

Linda Greve

Testbaseret optag til videregående uddannelser

Maria Cecilie Vonsild, Agner Holmberg Schibler, Agner Holmberg Schibler

Opgave- og skrivevejledning i klynger

Anmeldelse af Helle Merete Nordentoft

Dealing with emotions. A Pedagogical Challenge to Innovative Learning

Anmeldelse af Camilla Schmidt

Eksamensangst. Et problem vi skal løse i fællesskab 


\title{
At synliggøre, hvordan læring er blevet gjort mulig
}

\author{
Rie Troelsen, leder af SDU Universitetspæedagogik
}

"Kvalitet i universitetsundervisningen - forskningsbasering, praksisrelevans og strategisk indsats" var titlen på DUN-konferencen i maj 2015 - DUNs deltagermæssigt hidtil største konference. Fire oplægsholdere adresserede begrebet kvalitet i undervisning fra forskellige perspektiver, og gav hver især anledning til mange gode diskussioner blandt konferencedeltagerne om kvalitet. Herudover udgjorde en lang række oplæg, workshops og posters fra deltagerne selv en væsentlig del af konferencens input. Nogle bidrog med resultater fra forskningsundersøgelser på uddannelsessituationer, nogle med reflekterede beskrivelser af undervisningssituationer og andre med oplæg til diskussion af rammerne for både undervisning og uddannelse. Fælles for dem alle var, at de bidrog til at synliggøre universitetspædagogiske praksisser.

Nogle måneder senere - i november 2015 - blev der afholdt en anden konference med titlen "Fra årets underviser til strategisk indsats". Konferencen var arrangeret af Danmarks Evalueringsinstitut (EVA) i samarbejde med Dansk Universitetspæedagogisk Netværk (DUN) og handlede om anerkendelse af undervisning som en løftestang for øget kvalitet i undervisningen. Her præsenterede to hovedtalere hver deres bud på institutionelle tiltag, som skulle fremme anerkendelsen af gode undervisningskompetencer, ligesom udvalgte erfaringer med anerkendelsestiltag på danske universiteter blev diskuteret via to paneldebatter. Ved slutningen af konferencen var det tydeligt, at anerkendelse kan og skal gøres på mange måder - men gerne endnu mere!

Hvad har de to konferencer så med hinanden at gøre - udover sammenfaldet i arrangørorganisation og konferenceemne - kunne man spørge? Jo, ved anerkendelseskonferencen talte bl.a. den australske universitetspædagogiske forsker Keith Trigwell om at udvide anerkendelsen af undervisning til ikke kun at handle om værdsættelsen af selve handlingen, undervisning. Hvis undervisning skal anerkendes fx på lige fod med forskning, skal undervisning også - som forskning - indebære systematisk analyse af og refleksion over de studerendes læring inden for en teoretisk ramme samt dokumentation og offentliggørelse af resultaterne. Eller med Trigwells egne ord: "Making transparent how learning has been made possible" (Trigwell, 2012). Og det var netop, hvad de mange oplægsholdere på DUNs konference i maj gjorde - og hvad der gøres på DUN-konferencer generelt; synliggjorde hvordan læring var gjort mulig.

Så DUN-konferencerne er et rum for undervisere til at engagere sig i Scholarship of Teaching and Learning (SoTL), for det er hvad underviserens systematisk analyserende og dokumenterende refleksion over sin undervisningspraksis kaldes. SoTL er nemlig ikke kun noget som meget engagerede undervisere, der forsker intenst i deres undervisning og publicerer resultaterne i store, internationale tidsskrifter kan udøve. SoTL kan også, igen ifølge Trigwell, være en diskussion mellem to undervisere om den enes succesfulde afprøvning af en undervisningsmetode hentet fra litteraturen, hvilket leder til nedfældningen af et undervisningstip, som udsendes til samtlige kolleger på instituttet - eller præsenteres ved en DUN-konference. 
Derfor er DUN-konferencen et vigtigt medium, ikke alene for synliggørelsen af SoTL, men også for skabelsen af et praksisfællesskab om undervisning og uddannelse mellem universitetsansatte på tværs af institutioner og faggrænser. Så husk at melde dig til DUNkonferencen i maj 2016!

Et andet medium for synliggørelsen af SoTL er selvfølgelig nærværende tidsskrift, og nogle af artiklerne i dette nummer af Dansk Universitetspædagogisk Tidsskrift (DUT) er tilmed viderebearbejdninger af oplæg afholdt på DUN-konferencen. Tilsammen udgør DUNK og DUT således væsentlige kanaler for undervisere til at dokumentere og dele deres reflekterede erfaringer med undervisning - så brug dem endelig og vær med til at fremme anerkendelsen af undervisning og undervisningskompetencer!

Trigwell, K. (2012). Scholarship of teaching and learning. I: Hunt \& Chalmers (eds.): University teaching in focus: a learning-centred approach (s. 253-268). Acer Press

Links:

DUN-konferencen 2015: http://dun-net. dk/aktiviteter/2015/dun-konference-2015kvalitet-i-universitetsundervisningen-forskningsbasering-praksisrelevans-og-strategiskindsats/

EVA-konferencen: https://www.eva.dk/projekter/2015/konference-fra-arets-undervisertil-strategisk-indsats

Læs mere om SoTL i praksis her:

Jørgensen, A.H. \& Rienecker, L. (2015). Hvorfor skulle jeg dog skrive om undervisning? Om Scholarship of Teaching and Learning. I: Rienecker \& J ørgensen (red.). Universitetspædagogiske praksisser (s. 335-352). Samfundslitteratur.

Kan købes som e-kapitel på:

http://samfundslitteratur.dk/bog/universitetsp\%C3\%A6dagogiske-praksisser

Mårtensson, Roxå \& Olsson (2011). Developing a quality culture through the Scholarship of Teaching and Learning. Higher Education Research \& Development, 30 (1), 51-62.

Med udgangspunkt i en case fra Lunds Universitet fremhæeves det i denne artikel, at dokumentation af undervisningsmæssige kompetence, udvikling og perspektiv er afgørende for udvikling og fastholdelse af det personlige engagement i undervisningsudvikling. 


\title{
Tilstræbt og realiseret tværfaglighed i universitetsundervisning
}

\author{
Katrine Lindvig, ph.d.-studerende, Institut for Naturfagenes Didaktik, Københavns \\ Universitet
}

Lars Ulriksen, professor, Institut for Naturfagenes Didaktik, Københavns Universitet

Videnskabelig artikel (anonym peer-review)

\begin{abstract}
Formailet med denne artikel er at give undervisere, som er involveret i tvæerfaglige uddannelser og undervisning, et grundlag for at kunne reflektere over og diskutere følgende: Hvad sker der med tværfagligheden i undervisningen, og hvordan hænger det sammen med de didaktiske valg i planlæegning og udforelse? I artiklen sammenholder og præsenterer forfatterne forst de mest udbredte betegnelser for tværfaglighed. Ved hiælp af en case bestående af et tværfagligt kursus, udbudt over flere gange og med forskelligt design, peger forfatterne herefter på nogle af de udfordringer, der er forbundet med at praktisere tværfaglig undervisning. Artiklen konkluderer, at centrale didaktiske overvejelser om stofudvælgelse, arbejdsformer, eksamensformer samt deltagerforudsætninger og forventninger har afgørende betydning for realiseringen af den tilstræbte tværfaglighed.
\end{abstract}

Tværfaglig undervisning på danske universiteter er ingen nyhed. Gennem mere end 40 år har tværfaglighed været et centralt kendetegn for universiteterne i Roskilde og Aalborg, og både før og efter har der været tværfaglige uddannelser og kurser på de øvrige universiteter. I disse år synes der dog at blive udbudt flere uddannelser og kurser på tværs af klassiske fag. Uddannelsesguiden (Undervisningsministeriet, 2015) viser et bredt udbud af tværfaglige uddannelser, især på kandidatniveau ( $f x$ Klimaforandringer og Afrikastudier), men også på bachelorniveau (fx SPRØK og Folkesundhedsvidenskab). Mange undervisere indgår derfor i en eller anden form for tværfaglig ramme og skal forholde sig til, hvad tværfaglighed er.

Julie Klein noterer i sin efterhånden kanoniske bog Interdisciplinarity (1990:55) at man sædvanligvis finder tværfaglighed defineret ud fra eksempler (hvordan kan tværfaglighed se ud?), ud fra begrundelser (hvorfor tværfaglighed?), ud fra principperne for samspillet mellem de involverede fag, eller ud fra et terminologisk hierarki - ofte i forhold til forskellige grader af integration.

Alle fire tilgange er legitime og kan hver for sig bidrage til at blive klogere på, hvad tværfaglighed kan være og hvilke vanskeligheder, der kan ligge i tværfagligheden. En del af litteraturen er imidlertid tilbøjelig til at anlægge et normativt perspektiv, hvor begrundelsen for tværfaglighed gives som idealer, og terminologier præsenteres i værdihierarkier. Skal man forstå tværfagligheden i praksis, er det dog nødvendigt at løsrive terminologien fra værdierne og bruge den til at indkredse de tværfaglige praksisser. Begrundelserne for tværfaglighed skal ligeledes frigøres fra idealerne og i stedet bruges til både at forstå, hvorfor en uddannelse eller et kursus ser ud, som de gør, og hvorfor de nogle gange udvikler sig anderledes end planlagt.

Formålet med denne artikel er at give undervisere, som er involveret i tværfaglige uddannelser og undervisning, et grundlag for at kunne reflektere over og diskutere følgende: Hvad sker der med tværfagligheden i undervisningen, og hvordan hænger det sammen med de didaktiske valg i planlægning og udførelse? Artiklen består af tre dele. 
- 1 . del præsenterer og sammenholder kort nogle af de betegnelser, som bruges til at beskrive og diskutere tværfaglighed.

- 2. del diskuterer en case, nemlig et kursus udbudt ad tre omgange inden for den samme uddannelse, men med tre forskellige design og hvor forskellige niveauer af tværfaglighed er i spil inden for samme kursus.

- 3. og sidste del samler op på, hvad vi kan lære af eksemplerne, ikke mindst med hensyn til sammenhængen mellem den tilstræbte og den realiserede tværfaglighed.

\section{Definitioner og kategoriseringer af tværfaglighed}

Der findes ingen entydig definition af forskellige typer af tværfaglighed, men der er alligevel nogle fælles træk i sprogbrugen. Det skyldes blandt andet, at mange beskrivelser griber tilbage til en terminologi præsenteret af astrofysikeren Eric Jantsch på en OECD-konference i 1972. Hans definitioner benyttes enten direkte eller som grundlag for videreudvikling i de mest citerede internationale tekster om tværfaglighed (bl.a. Klein, 1990, 1996; Lattuca, 2002; Moran, 2010; Newell, 1994; Weingart \& Stehr, 2000).

Jantsch (1972) opererede med fem niveauer, og Klein (1990) argumenterer for, at der på tværs af de omfattende forsøg på at fastlægge en terminologi tegner sig en enighed om tre hovedtyper. I tabellen har vi sammenstillet Jantschs og Kleins inddelinger sammen med et bud på en dansk oversættelse af navnene på de forskellige niveauer (Ulriksen, 2008). Endelig har vi i kolonnen yderst til højre peget på kvalitative forskelle mellem de tre trin (uddybes nedenfor).

\begin{tabular}{|l|l|l|l|l|}
\hline Niveau & Jantsch & Ulriksen & Klein & Kort sagt \\
\hline 1 & Multidisciplinarity & Mangefaglighed & \multirow{2}{*}{ Multidisciplinarity } & $1+1=2$ \\
\cline { 1 - 2 } & Pluridisciplinarity & Flerfaglighed & & \\
\hline 3 & Crossdisciplinarity & Støttefaglighed & Interdisciplinarity & $1+1=3$ \\
\hline 4 & Interdisciplinarity & Mellemfaglighed & Transdisciplinarity & $1+1=1$ \\
\hline 5 & Transdisciplinarity & Overskridende faglighed & &
\end{tabular}

De første to af J antschs fem niveauer, 'multidisciplinarity' ('mangefaglighed') og 'pluridisciplinarity' ('flerfaglighed') er kendetegnet ved en begrænset grad af kontakt mellem de involverede fag. 'Mangefagligheden' er en sidestillet vifte af forskellige fag, "without making explicit possible relationships between them" (Jantsch, 1972:15), mens 'flerfagligheden' rummer "cooperation without coordination" (ibid.). De forskellige fag sættes i forhold til hinanden, så de bidrager med forskellige vinkler i forhold til det faglige indhold. Med en 'flerfaglig' tilgang er emnet fælles, men de deltagende fag behandler hvert deres aspekt uden nødvendigvis at have særligt meget interaktion. Det kan være flere fag, som belyser det samme tema, fx arbejdsløshed, ud fra et juridisk, et psykologisk, et økonomisk og et litteræert perspektiv. Hvert perspektiv bidrager til en mere nuanceret forståelse af arbejdsløshed, men den juridiske tilgang bliver ikke udfordret af en psykologisk tilgang eller den litterære af en økonomisk.

På J antschs tredje niveau, 'crossdisciplinarity' ('støttefaglighed') skal et eller flere støttefag tilpasse sig det dominerende fags forståelser, tilgange og behov. J antschs første tre niveauer svarer til den første af Kleins typer, nemlig 'multidisciplinarity', hvor der er en modstilling af forskellige fag, som er "grundlæggende additiv, ikke integrerende" (Klein, 2010:56, vor oversættelse).

Det fjerde niveau hos Jantsch, 'interdisciplinarity' ('mellemfaglighed'), vil ofte tage udgangspunkt i en problemstilling på en måde, så der skabes noget fælles mellem fagene. Det er dog inden for den 'mellemfaglige' tilgang stadig muligt at skelne de forskellige faggrænser 
og forstå hvem, der bidrager med hvad. Derimod ligger der i 'transdisciplinarity' ('overskridende faglighed') en opløsning af oprindelige faggrænser til fordel for et fælles felt og en udvikling af nye metoder eller tilgange.

Klein skelner på samme måde mellem 'mellemfaglighed' og 'overskridende faglighed'. Hun forbinder 'interdisciplinarity' med en grad af integration mellem de fag, som indgår, og en integration, som ikke er overladt til de studerende, men hvor graden af integration kan variere. I mange tilfælde er denne form for tværfaglighed knyttet til løsning af problemer (teoretiske eller praktiske). Med 'transdisciplinarity' bevæger man sig fra en integration til en syntetisering om bestemte begreber eller forståelsesrammer ( $f x$ kybernetik eller systemteori (Klein, 1990:65)). Det er også ved 'transdisciplinarity', der er den største afstand mellem ideal og virkelighed, skriver hun. Kleins type 2 svarer altså til Jantschs niveau fire, mens niveau fem svarer til Kleins type 3.

\section{De kvalitative forskelle}

Kleins tre typer udtrykker nogle kvalitative spring, som vi har sammenfattet i kolonnen "Kort sagt". I den første lægges de deltagende fag blot ved siden af hinanden. 'Mangefagligheden' fører ikke nødvendigvis til en samlet forståelse (man kunne sige at $1+1=1+1$ ). I både 'flerfagligheden' og 'støttefagligheden' betyder inddragelsen af flere fag, at man kan se på et felt fra flere sider, men fordi de ikke bliver integreret, opstår der ikke noget ekstra. Derfor er $1+1=2$.

I 'mellemfagligheden' bliver summen af samarbejdet større end summen af de bidragende fag uden at grænserne mellem fagene forsvinder. Integrationen af fagene frem for den simple læggen-sammen betyder, at der opstår noget ekstra ud over enkeltfagene. I 'mellemfagligheden' bliver $1+1=3$. Der sker også noget nyt i den 'overskridende faglighed', men da der her tendentielt sker en opløsning af faggrænserne, bliver resultatet derfor noget nyt, selvstændigt og fritstående: $1+1=1$.

De kvalitative spring knytter sig altså til, hvorvidt der opstår noget ekstra men også til, hvorvidt de involverede fag bliver anfægtet af at indgå i det tværfaglige samarbejde. På Kleins trin 1 står fagene uanfægtede tilbage, mens de på trin 2 er nødt til at tilpasse sig de faglige sammenhænge, de indgår i, og på trin 3 mere eller mindre opløses. En del af forskellene i graden af tværfaglighed på trin 2 vedrører derfor, i hvilken udstrækning de involverede fag underordner sig det fælles anliggende, som tværfagligheden orienterer sig imod. Eksempelvis vil problembaseret projektarbejde ofte beskrive et problem ( $\mathrm{fx}$ en case) ud fra de faglige elementer, man ønsker, de studerende skal arbejde med. Her er faget det styrende. I det problemorienterede projektarbejde begynder man i problemet og inddrager derefter elementer fra fagene, som er relevante for at belyse problemet jf. Simonsen og Ulriksen (1998: 182ff.).

I den næste del vil vi illustrere forskellene og nuancerne mellem de forskellige definitioner og samtidig vise, hvor lidt der skal til, for at typen af tværfaglighed ændres i en undervisningssammenhæng. Det gør vi ved hjælp af en case fra vores igangværende forskning i tværfaglig undervisning og uddannelse på Københavns Universitet (KU). Her undersøger vi bl.a. hvordan tværfaglig forskning bliver til tværfaglig uddannelse, lige fra hvordan ideerne opstår, over hvordan forskerne planlægger uddannelsesaktiviteter, og hvordan disse aktiviteter bliver gennemført og modtaget af de studerende.

\section{Metode}

Casen består af et tværfagligt kursus som udbydes som tilvalgskursus på kandidatuddannelsen i Folkesundhedsvidenskab på KU. Kurset udspringer af et større tværfagligt forskningsprojekt omhandlende fedme. Planlægningen af kurset begyndte i efteråret 2013, og kurset blev afviklet første gang i efteråret 2014. Herefter blev det udbudt som sommerskole i sommeren 2015 og vil blive gentaget i sommeren 2016. 
Ved hjælp af etnografisk inspirerede metoder (Marcus, 1995; Willis, 2000) har vi fulgt planlægningen og udviklingen af kurset helt fra begyndelsen. Vi har deltaget i uddannelsesgruppens planlægningsmøder, været c.c. på samtlige mailkorrespondancer relateret til kurset, interviewet kursets undervisere før og efter deres undervisningsgange, gennemført tre fokusgruppeinterviews med i alt 12 studerende fra kurserne, observeret undervisning samt fulgt den mundtlige og skriftlige evaluering af de to gennemførte kursusforløb. Gennem hele forløbet har vi været i dialog med den kursusansvarlige og de øvrige deltagere i planlægningsgruppen om de didaktiske overvejelser relateret til kurset. Denne betydelige mængde empiri har vi kunnet producere, fordi vi fra starten har fået adgang til samtlige niveauer af planlægning, gennemførelse og evaluering - og fordi kursusforberedelsen efter vores vurdering har været ekstraordinært grundig.

Tværfaglighed vil komme forskelligt til udtryk i forskellige kurser og uddannelser. Med denne case ønsker vi imidlertid at vise, at der også inden for et enkelt kursus kan forekomme en række forskellige typer tværfaglighed. Ved at bruge et grundigt gennemarbejdet kursus som case (Flyvbjerg, 2011) får vi mulighed for at undersøge udfordringerne ved at realisere den tilstræbte tværfaglighed med fokus på de didaktiske udfordringer, frem for på bureaukrati, økonomi og logistik.

I de følgende afsnit vil vi kort gennemgå kursets udvikling, hvilke overvejelser, der var forbundet med typen af tværfaglighed samt de udfordringer, som opstod i gennemførelsen af kurset. I gennemgangen benytter vi tre metaforer til at beskrive de former, kurset antager. Disse metaforer illustrerer måden fagene bringes i forbindelse med hinanden på, frem for $i$ hvilken grad fagene integreres (som i tabellen). Metaforerne kan altså dække tilrettelæggelsesformer, som i princippet kan findes på flere af de niveauer, som er beskrevet i tabellen.

\section{Kandidatkursus 2014: Governing obesity}

Da kurset første gang blev gennemført i efteråret 2014, bar det titlen "Governing Obesity". Kurset blev udbudt på tværs af fakulteter og universiteter, og adgangskravet var en bachelorgrad inden for et relevant område. Kursets formål var ifølge kursusbeskrivelsen:

"[T]o introduce students to perspectives from several disciplines on obesity with the dual purpose of training interdisciplinary thinking and understanding, and an understanding of the complex causes and aspects of interventions towards obesity".

Dette formål afspejlede en af de bærende motivationer fra det bagvedliggende tværfaglige forskningsprojekt, nemlig at fedme er et så komplekst problem, at det umuligt kan forstås og løses med en enkeltfaglig tilgang.

Den første undervisningsgang omhandlede tværfaglighed og videnskabsteori og havde til formål at introducere en begrebsramme for de følgende ni undervisningsgange og samtidig klæde de studerende på til det tværfaglige arbejde. Hver undervisningsgang havde en titel ( $f x$ "Responsibility and stigma"), og på hver undervisningsgang à to timer underviste to forskere med forskellig baggrund. Underviserne kom fra en række fag på tværs af humaniora, samfunds- og naturvidenskab. Tanken var, at der på hver undervisningsgang blev knyttet an til de øvrige fagligheder og reflekteret over implikationer ved de forskellige tilgange. Efter hver anden undervisningsgang var der studenterpræsentationer på baggrund af opgaver knyttet til de foregående to undervisningsgange. Præsentationerne og opgaverne indgik som en del af de studerendes portfolioeksamen og skulle sammen med den afsluttende skriftlige opgave bestås, for at de studerende kunne opnå de 10 ECTS point. Som en måde at koble de forskellige undervisningsgange og fag, deltog kursuslederen i samtlige undervisningsgange. 
På baggrund af denne planlægning var tværfagligheden i kurset tænkt som 'mellemfaglig'. Der var en forventning om, at underviserne koblede deres fagligheder i undervisningsgangene, og de studerende forventedes at trække på deres forskellige fagligheder og inddrage forskellige faglige tilgange i deres afleveringer og præsentationer.

\section{Perler på snor}

Selvom der var lagt op til 'mellemfaglighed' på flere niveauer (emne, undervisere, metoder og studentersammensætning) blev "Governing Obesity" i realiteten snarere en blanding af et 'mangefagligt' og 'flerfagligt' kursus. Det kan der være flere forskellige grunde til:

I evalueringen gav de studerende udtryk for, at det især var en manglende kobling mellem de forskellige forelæsninger, der gjorde det svært at skabe en faglig syntese omkring det fælles emne. Stofmængden på kurset betød, at det ikke også kunne rumme sammenkædende diskussioner mellem de repræsenterede fagligheder, og selvom kursuslederen var til stede som bindeled mellem undervisningsgangene, var indholdet for forskelligt til at kunne bindes sammen.

I vores interview udtrykte underviserne forskellige holdninger til kursets formål: En af underviserne mente, at kurset skulle præsentere de studerende for en række topforskere inden for fedmeforskning, en anden pointerede nødvendigheden af tværfaglighed og forskellige faglige blikke på fedme, og en tredje understregede, at kursets formål var at give de studerende en række introduktioner til måder at arbejde med fedme på. De tre opfattelser udelukker ikke hinanden, og ingen af dem er sådan set forkerte i forhold til det endelige resultat. De kan dog alligevel have været medvirkende til, at de enkelte undervisningsgange mere kom til at fremstå som en række perler på en snor, end som et samlet hele med overlap mellem de forskellige faglige tilgange. Hvis de enkelte undervisere ikke er opmærksomme på at skabe overgange til de øvrige fag og ikke kender fagene, som de skal knytte an til, så bliver det svært for kursuslederen og for de studerende at kæde undervisningsgangene sammen.

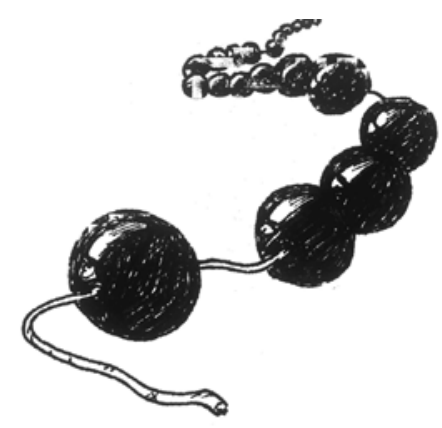

De studerende udtrykte, at der havde været en del forvirring om formålet med de forskellige opgaver og studenterpræsentationer. De var ikke klar over, om formålet var at lære en ny metode (fx posterpræsentation), eller om fokus var på indholdet. Det betød, at flere af de studerende holdt sig til det, de allerede kendte, og dermed ikke havde oplevet en integration af forskellige fag. Endelig blev studentersammensætningen heller ikke så mangfoldig som forventet (over $90 \%$ var fra Folkesundhedsvidenskab), hvilket også resulterede i en mindre grad af tværfaglighed de studerende imellem.

Ovenstående peger på, at selv små forstyrrelser kan have ret tydelige konsekvenser i et tværfagligt undervisningsmaskineri. Enkelte instrukser, som ikke videregives tydeligt nok, underviseres implicitte forståelser af kursusindhold og -sammenhæng samt en ændret studentersammensætning, kan ændre graden af tværfaglighed $\mathrm{n}$ til to niveauer ( $\mathrm{f}$. ovenstående skema). 


\section{Sommerskole 2015: Obesity in a crossdisciplinary perspective}

Hvor det første kursus blev udbudt som semesterkursus, blev dette udbudt som en to ugers intensiv sommerskole. Evalueringerne fra det første kursus resulterede først og fremmest i en ændring af kursusbeskrivelsen, således at ordet 'interdisciplinary' blev erstattet af 'crossdisciplinary' (ikke i J antschs betydning, men som en ikke nærmere præciseret ambition om at arbejde på tværs af fagene). Desuden reducerede man antallet af undervisere fra 17 til 12 og lod kursuslederen optræde flere gange igennem kurset med den hensigt at skabe sammenhæng. For at undgå stoftrængslen fra det første kursus, skar man ned på antallet af emner og fordoblede det antal timer, man brugte på hvert emne. Endelig ændrede man titlerne på undervisningsgangene, så flere af dem refererede direkte til de fag, de udsprang af ( $\mathrm{fx}$ "Law and discrimination", "Economy and obesity"). Der var stadig indlagt små opgaver, øvelser og gruppearbejde imellem de enkelte undervisningsgange, men da der ikke var samme mulighed for forberedelse som i semesterkurset, blev eksamensformen erstattet af en afsluttende essayopgave, som de studerende skulle aflevere en måned efter kursets afslutning.

Endelig skulle de studerende selv skabe integrationen mellem fagene i kurset. Det skulle ske i de studerendes individuelle og online kursusforberedelse, i gruppearbejde mellem studerende med forskellige fagligheder samt i eksamensopgaven, hvor de studerende blev bedt om at diskutere et emne/spørgsmål ud fra to forskellige faglige tilgange.

\section{Lynlåsen}

Kurset modtog yderst positive tilbagemeldinger fra de studerende. De syntes onlinedelen fungerede godt, og at det var nemt at orientere sig og få overblik over kursets forskellige dele. Kursuslederen havde gjort det klart, at de selv skulle koble de forskellige fag, og at det ikke var 'mellemfaglighed', men en mere sideordnet tværfaglighed, svarende til de tre niveauer, Klein kalder 'multidisciplinarity' (se tabellen), der var lagt op til. De studerende havde derfor ikke en forventning om en større integration af de enkelte fag. Dette forløb antog altså en anden form end det første kursus. Man kan sige, at der var tale om en lynlåsmodel, hvor de studerende skaber forbindelse mellem de forskellige fag, mens underviserne og undervisningen bliver på enkeltfagligt grundlag.

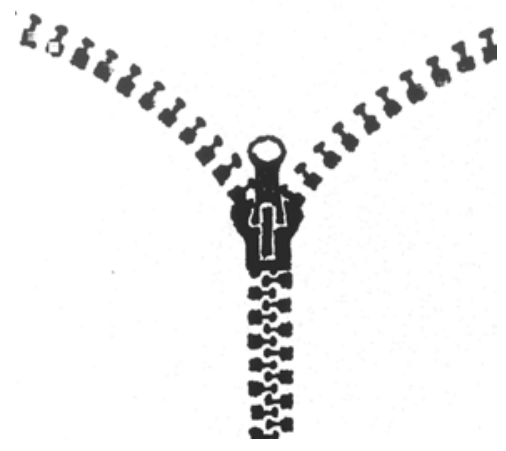

Den primære kritik af kurset vedrørte det faglige niveau. Fordi underviserne talte ud fra hver deres eksempler og indgange til fedmeproblematikken, var det meget forskelligt, hvordan de introducerede deres fag. Nogle undervisere indledte på et meget grundlæggende niveau, mens andre meget hurtigt bevægede sig op til et meget specialiseret og fagspecifikt niveau. Underviserne gav selv udtryk for, at de syntes det var svært at vurdere, hvor de skulle begynde, fordi gruppen af studerende var så blandet. Dette er en velkendt udfordring i tilrettelæggelsen af tværfaglig undervisning, idet der er så mange variabler i spil (Davis, 1995; Lattuca, Voigt \& Fath, 2004). De forskellige niveauer og tilgange i undervisningen betød også, at den afsluttende opgave ikke fungerede optimalt ift. at binde de forskellige 
dele sammen. Kravene blev undervejs ændret fra, at eksamensopgaven skulle rumme to perspektiver til kun ét perspektiv. At der i begge forløb har været udfordringer forbundet med eksamensdelen bekræfter det generelle billede af eksamination og evaluering af tværfaglig undervisning og uddannelse (Boix Mansilla \& Duraisingh, 2007; Haynes \& Leonard, 2010; Mansilla, 2005). Det er en udfordring at finde en metode, der kan vurdere den tværfaglige læring på tværs af faglige traditioner og kriterier og samtidig kan tale sammen med det øvrige og primært enkeltfaglige evalueringssystem.

\section{Sommerskole 2016: Obesity - a crossdiciplinary approach}

På baggrund af de to tidligere kursusforløb diskuterede planlægningsgruppen, hvordan man i sommerskolen 2016 kan styrke sammenhængen mellem de forskellige fag og samtidig sørge for, at undervisningsindholdet bevæger sig op over det introducerende niveau og bliver mere emnespecifikt. I de to forløb var undervisningsgangene centreret om hhv. tematikker og enkeltfaglige tilgange til fedme. Det satte meget fokus på de enkelte fag men mindre fokus på emnet og måden, de forskellige fag interagerer på. Det blev derfor foreslået at tilrettelægge en mere casebaseret undervisning med inspiration fra det bagvedliggende forskningsprojekt, så det ikke er fagene, der definerer undervisningsgangene, men en række spørgsmål, som samler fagene på tværs. Undervisningsgangene kan så struktureres omkring fem cases med to-tre undervisningsdage til hver, og med en gruppe af undervisere som vil kunne koordinere deres bidrag og tilbyde en mere fokuseret undervisning.

\section{Snekrystallen}

Hvis det lykkes at komme til at arbejde med nogle fælles cases og problemstillinger, så vil kurset kunne rumme tværfaglighed, som både er 'mangefaglig', 'flerfaglig' og måske også 'mellemfaglig'. Det er også muligt, at studerende med forskellig faglig baggrund kan skrive en opgave med fokus på en given case, hvor de benytter metoder fra et fag til at understøtte et andet og dermed skabe en form for 'støttefaglighed'.

Det vil have en betydning, at underviserne inden for de respektive cases mødes inden undervisningen og diskuterer sammenhænge, overgange og mulige overlap mellem deres forskellige fag. Endelig vil formuleringerne af de opgaver, som skal indgå i portfolioeksamen, være vigtige mht. at tydeliggøre, hvilken tværfaglighed man tilstræber hos de studerende. Med justeringer som disse vil der i givet fald være tale om tværfaglighed som antager form af en snekrystal, dvs. en række forskellige fag, som samles omkring et hele, og som griber ud og skaber tæette forbindelser imellem fagene.

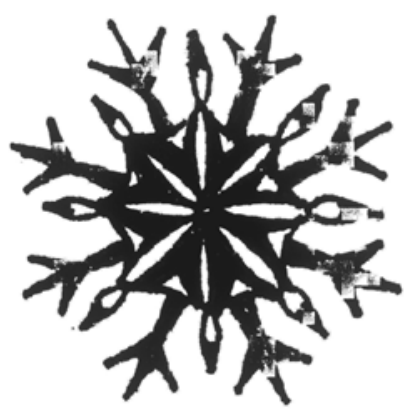

\section{Diskussion og konklusion}

Vores case peger dels på nogle af de former, tværfaglighed kan antage i undervisning og uddannelse, og dels på, at graden af tværfaglighed kan forandre sig, når blot nogle fă parametre ændres. De tre gennemløb viser, at der i den realiserede undervisning kan være flere forskellige typer tværfaglighed i spil (Klein, 1990:169) og være glidende overgange mellem typerne. De tre variationer af kurset viser samtidig betydningen af centrale didaktiske overvejelser om stofudvælgelse, arbejdsformer, eksamensformer samt om deltagerforudsætninger og forventninger. 
I første gennemløb hæmmede stoftrængsel tværfagligheden. Da stoftrængslen blev mindsket i andet forløb viste der sig problemer ved stofudvælgelsen, bl.a. fordi de studerendes forudsætninger var forskellige. Disse problemer blev muligvis forstærket af, at stofudvælgelsen i andet gennemløb var enkeltfaglig, fordi spredning i deltagerforudsætninger her får større betydning, end hvis indholdet udvælges i forhold til temaer. Erfaringerne fra tredje gennemløb i sommeren 2016 vil muligvis belyse dette.

Ydermere svækker tilrettelæggelse med udgangspunkt i et enkelt fag tværfagligheden ikke mindst hvis undervisningen varetages af mange specialister frem for færre undervisere, som kan forsøge at binde enkeltdelene sammen. Undervisning ud fra et fælles problem eller case (snekrystallen) vil kunne betyde, at det tværfaglige fremstår mere relevant, og at de studerende praktiserer tværfaglighed i kursets undervisningsaktiviteter.

Det peger hen på, hvilke forventninger der er til de studerendes rolle i skabelsen af tværfaglighed. I det andet gennemløb blev det eksplicit overladt til de studerende at skabe forbindelsen, og sammenknytningen skulle foregå uden for selve undervisningen. I det første gennemløb var forventningen, at tværfagligheden skulle skabes fælles i løbet af undervisningen, men uden at det lykkedes.

Endelig påvirkede eksamensformatet i begge realiserede tilfælde tværfagligheden. I første eksempel fordi læringsmålet ikke var klart for de studerende, og i det andet fordi kompleksiteten i kursustemaet fik kursuslederne til at mindske de tværfaglige ambitioner.

En bedre realisering af en tilstræbt tværfaglighed kan ske ved, at kursuslederen ekspliciterer sine forventninger til type og grad af integration mellem fagene, til måden man ønsker at dette skal lykkes på, samt til de forskellige aktørers rolle i denne integration. I den forbindelse er det vigtigere at gøre sig klart, hvilken type og grad der bedst tjener formålet med kurset, end at stræbe efter at opnå den storst mulige faglige integration.

Udviklingen af tværfaglig undervisning kan ikke alene foregå i beskrivelsen af læreplaner og kursusindhold. Det må også sætte sig spor i stofudvælgelsen, i den måde undervisningen tilrettelægges, og i den måde underviserne arbejder sammen på. Det kræver at planlæggere og undervisere afsætter ressourcer til en tæt koordinering og gensidig afklaring - både før og undervejs i undervisningen.

\footnotetext{
Katrine Lindvig er ph.d.-studerende ved Institut for Naturfagenes Didaktik på Københavns Universitet. Hun er uddannet cand.scient.soc. i Pæedagogik og Uddannelsesstudier samt Internationale Udviklingsstudier. I sit ph.d.-studie undersøger hun, hvordan forskellige typer af tværfaglig uddannelse og undervisning skabes i kølvandet på tværfaglig forskning. Forud for sit ph.d.-forløb har hun været tilknyttet forskningsprojekter omhandlende tværfaglig forskning og samarbejde, faglig identitet på nye universitetsuddannelser samt hybride kvalifikationer i erhvervsuddannelserne.
}

Lars Ulriksen er professor i Naturfagenes Uddannelsessociologi ved Institut for Naturfagenes Didaktik på Københavns Universitet. Hans primære forskningsinteresse er mødet mellem deltagerne og uddannelser, herunder uddannelsernes opbygning, de undervisningsformer som bruges, og hvad det forudsætter hos deltagerne - ikke mindst hos de studerende. Han har tidligere beskæftiget sig med projektarbejde og tværfaglighed og de udfordringer, uddannelsernes enkeltfaglige traditioner stiller tværfaglighed overfor. 


\section{Litteratur}

Boix Mansilla, V. \& Duraisingh, E. D. (2007). Targeted assessment of students' interdisciplinary work: An empirically grounded framework proposed. The Journal of Higher Education, 78(2), 215-237. doi: 10.1353/jhe.2007.0008

Davis, J. R. (1995). Interdisciplinary courses and team teaching: new arrangements for learning. Phoenix, Ariz: . American Council on Education and the Oryx Press.

Flyvbjerg, B. (2011). Case study. I: N. K. Denzin \& Y. S. Lincoln (red.), The Sage Handbook of Qualitative Research (4th edition) (s. 301-316). Los Angeles/London/New Delhi/Singapore/Washington DC: SAGE Publications.

Haynes, C. \& Leonard, J. B. (2010). From surprise parties to mapmaking: Undergraduate journeys toward interdisciplinary understanding. The Journal of Higher Education, 81(5), 645-666.

Jantsch, E. (1972). Inter- and transdisciplinary university: A systems approach to education and innovation. Higher Education, 1(1), 7-37. doi: 10.1007/BF01956879

Klein, J. T. (1990). Interdisciplinarity: history, theory, and practice. Detroit: Wayne State University Press.

Klein, J. T. (1996). Crossing Boundaries: Knowledge, Disciplinarities, and Interdisciplinarities. Charlottesville, Va: University Press of Virginia.

Klein, J. T. (2010). A taxonomy of interdisciplinarity. I: R. Frodeman, J. T. Klein \& C. Mitcham (red.), The Oxford Handbook of Interdisciplinarity (s. 15-30). Oxford: Oxford University Press.

Lattuca, L. R. (2002). Learning interdisciplinarity: Sociocultural perspectives on academic work. The Journal of Higher Education, 73(6), 711-739. doi: 10.1353/jhe.2002.0054

Lattuca, L. R., Voigt, L. J. \& Fath, K. Q. (2004). Does interdisciplinarity promote learning? Theoretical support and researchable questions. Review of Higher Education, 28(1), 23-48.

Mansilla, V. B. (2005). Assessing student work at disciplinary crossroads. Change: The Magazine of Higher Learning, 3ᄌ1), 14-21. doi: 10.3200/CHNG.37.1.14-21

Marcus, G. E. (1995). Ethnography in/of the world system: The emergence of multi-sited ethnography. Annual Review of Anthropology, 24, 95-117.

Moran, J. (2010). Interdisciplinarity (2. ed.). London: Routledge.

Newell, W. H. (1994). Designing interdisciplinary courses. New Directions for Teaching and Learning, 1994, 35-51. doi: 10.1002/tl.37219945804

Simonsen, B. \& Ulriksen, L. (1998). Universitetsstudier i krise. Fag, projekter og modeme studenter (Vol. 94/98). Frederiksberg: Roskilde Universitetsforlag.

Ulriksen, L. (2008). Det sociologiske perspektiv. I F. B. Olsen \& F. Held (red.), Introduktion til paedagogik. Opdragelse - Dannelse - Socialisering (2. udg.), s. 49199). Frederiksberg: Frydenlund.

Undervisningsministeriet. (2015). Uddannelsesguiden. Fundet 22. oktober, 2015, på www.ug.dk.

Weingart, P. \& Stehr, N. (2000). Practising Interdisciplinarity. Toronto: University of Toronto Press.

Willis, P. (2000). The Ethnographic Imagination. Cambridge: Polity. 


\title{
Sker der noget med læringsudbyttet, når undervisningssproget skiftes?
}

\author{
Camilla Falk Rønne Nissen, ph.d.-stipendiat, Institut for Nordiske Studier og \\ Sprogvidenskab, Københavns Universitet
}

Lars Ulriksen, professor, Institut for Naturfagenes Didaktik, Københavns Universitet

\section{Videnskabelig artikel (anonym peer-review)}

I takt med en øget internationalisering af de videregående uddannelser øges mængden af undervisning på engelsk på de danske universiteter. Men hvilke konsekvenser har det for kvaliteten af undervisningen? Falder læringsudbyttet, når der undervises på et sprog, der for de fleste universitetsstuderende og undervisere ikke er deres forstesprog? Denne artikel prover gennem et litteraturreview at finde svar i den eksisterende, forskningsbaserede litteratur. Forste del af reviewet identificerer interesseområder i forskningen, mens anden del gennemgår resultater fra enkelte studier med fokus på læring og deltagelse, særligt i en nordisk kontekst.

\section{Introduktion}

Siden Bologna-deklarationen blev underskrevet i 1999, har ønsket om at skabe "et europæisk område for videregående uddannelser" bl.a. ført til et fokus på studerendes muligheder for at tage uddannelser på tværs af nationalgrænser. I praksis har studentermobilitet betydet, at mængden af undervisning på engelsk på de danske universiteter er steget, og Danmark er i øjeblikket det land i Europa med den højeste andel kurser og programmer udbudt på engelsk (Lauridsen, 2015). Den udvikling forstærkes af, at universitetet som institution i stadig stigende grad forventes at profilere sig og være konkurrencedygtigt på et globalt marked, hvor undervisning er en vare, der kan sælges (se Philipson 2006; Mortensen \& Haberland 2009, 2012). ÆEndring af undervisningssproget til det "globale sprog" engelsk gør det muligt at ekspandere markedet. For at kunne tiltrække studerende og forskere udefra, er det nemlig nødvendigt at undervise på et andet sprog end dansk - i reglen engelsk.

Undervisningen på universiteter i ikke-anglofone områder vil i stadigt stigende grad foregå på et sprog, der for de fleste deltagere hverken er deres første eller bedste sprog, og dette rejser en række spørgsmål, bl.a. om konsekvenserne for kvaliteten af uddannelsesforløbet (se Vinke 1995; Klaassen 2001). Falder læringsudbyttet, når der undervises på et andetsprog? Bliver undervisnings- og læringsaktiviteter påvirket?

Denne artikel prøver dels at finde svar i den eksisterende litteratur, dels at vise et øjebliksbillede af status på forskning, der beskæftiger sig med undervisning på et andetsprog. Andetsprog kan defineres som et sprog tilegnet efter førstesproget i en kontekst, hvor det fungerer som kommunikationsmiddel fx med autoriteter på arbejde eller universitetet (Holmen, 2006). I et universitetspædagogisk perspektiv er læringsudbytte et interessant perspektiv, men det rummer samtidig forskellige aspekter (Illeris, 2006). Når læringsmål i stigende grad udtrykkes som kompetencer, understreger det en forståelse af viden som tæet forbundet med situerede praksisser, og at det ikke blot drejer sig om, hvad man har lært, men også hvordan det er integreret i den øvrige viden og den identitet, man har (fx Ulriksen, 2014). Læring på universitet er derfor både udvikling af faglige kompetencer og socialisering til at blive en del af et fagligt fællesskab. 


\section{Metode}

Dette studie er et litteraturreview af forskningsbaseret litteratur om undervisning på et andetsprog med udgangspunkt i ovenstående spørgsmål, hvor første del af reviewet handler om generelle trends i forskning omkring undervisning på et andetsprog og internationalisering af videregående uddannelser. Anden del fokuserer på de konsekvenser for læringsudbyttet, det kan have at blive undervist på et andetsprog.

Litteratursøgningen er foretaget på ERIC (Education Resources Information Centre, http://www.eric.ed.gov/), hvor søgningen har taget udgangspunkt i følgende: English Medium Instruction, International Education, Language of Learning and Teaching, Integrating Content and Language og Learning through foreign language. Søgningen blev afgrænset til videregående uddannelse og til en tidsramme fra 1995-2015. Tekster, som handlede om undervisning på engelskuddannelser, er sorteret fra. Det er således kun tekster, hvor sproget bruges som medium og ikke er et mål i sig selv, der er medtaget. Tekster om tegnsprog er ligeledes sorteret fra. Søgningen var afgrænset til peerreviewede tekster. Afgrænsningen var dels pragmatisk (ikke peer-reviewet litteratur er tidskrævende at finde), dels ud fra det rationale, at undervisere og planlæggere, som skal udvikle eller undervise på andetsprogsbaserede kurser, vil være henvist til den officielle, overvejende peer-reviewede litteratur. Dog er enkelte afhandlinger, rapporter og bøger så centrale i forskningen, at de alligevel indgår.

I første omgang læstes abstracts af alle tekster fra søgningen for at bekræfte deres relevans for nøgleordene: læring og deltagelse. Tekster uden relevans blev skåret fra, bl.a. om ph.d.-niveau og international publicering. Kategoriseringen af abstracts har til formål at skabe et overblik over temaer i forskningen. Kategorierne opstod ved læsning af abstracts og dannede samtidig rammen for videre læsning. De er altså både et resultat og en del af metoden. Samme tekst kan godt optræde i forskellige kategorier. Teksterne er opdelt i dansk litteratur, øvrig skandinavisk litteratur og international litteratur for at identificere eventuelle forskelle i interesseområder. Opdelingen er foretaget på baggrund af den kontekst, forskningen er udført i, altså har fx dansk litteratur danske universiteter som genstandsområde.

De identificerede kategorier:

- Holdninger:

Indeholder tekster om hhv. studerende, undervisere og andre akademiske medarbejderes holdninger til sprogpolitik, til det at undervise eller blive undervist på engelsk eller til sprog og sprogformer.

- Oplevelse:

Indeholder tekster om studerendes læringsoplevelse eller underviseres oplevelse af at undervise på engelsk, samt erfaringer med eller forventninger til undervisningen.

- Læringsudbytte:

Indeholder tekster om learning outcome, achievement outcome, student performance og academic performance. Altså læring, men også betragtet som præstationer, fx ved eksamener og prøver.

- Undervisning og deltagelse:

Indeholder tekster om studenteraktivitet, fx aktivitet i klasserummet eller at indgå i kommunikation med ligesindede. 
- Sproglige problemer:

Indeholder tekster om sproglige problemer og/eller sproglig support.

- Sprog og identitet:

Indeholder tekster om uoverensstemmelse mellem faglig og sproglig identitet eller anfægtet national identitet. Når man bruger sprog, signalerer man identitet, og identiteten kan blive påvirket, når man taler et sprog, man ikke mestrer til fulde. Derudover kan der være årsager til, at ét sprog har højere prestige end et andet, eller at den nationale identitet i sprogbrugen er stærk.

- Sprogvidenskab:

Indeholder tekster om sproglige fænomener i en international kontekst snarere end selve undervisningssituationen, hovedsageligt engelsk som lingua franca, altså som fællessprog, og kodeskift.

- Internationalisering:

Indeholder sprogpolitiske tekster, tekster om udenlandske studerende/studentermobilitet, samt erfaringer med eller anbefalinger til internationalisering af videregående uddannelse, herunder rekruttering af internationale studerende.

Kategorierne er dannet på baggrund af teksternes selverklærede genstandsområder. Eftersom læring som nævnt rummer flere dimensioner, og fordi kompetencer knytter sig til situationer, kan alle kategorierne have betydning for de studerendes læringsudbytte. Holdninger til sprogbrugen kan påvirke motivationen og den følelsesmæssige side af læreprocessen, sproglige problemer kan have betydning for mulighederne for at deltage i læringsaktiviteter og dermed for udbyttet, og internationaliseringen kan betyde en større spredning i de studerendes forudsætninger, såvel kulturelt som hvilke erfaringer, de har med at indgå i undervisningsaktiviteter. Disse sociale, kulturelle, følelsesmæssige og politiske aspekter kan alle påvirke de studerendes læring sådan, at det, de lærer, bliver noget andet end det, underviseren havde til hensigt, ligesom lærerens forståelse for det ændrede læringsrum kan betyde, at det, læreren gør, bliver til noget andet end det, hun havde til hensigt (Tamir, 1998). Vi har i denne artikel valgt at fokusere på kategorierne Læringsudbytte og Undervisning og deltagelse og har herved altså kun set på selve undervisningssituationen.

Efter kategoriseringen udvalgte vi artikler, der optrådte i de to udvalgte kategorier. De blev nærlæst, og en gennemgang af enkelte særligt relevante tekster er at finde i denne artikels resultatafsnits anden del. Undervejs i kategoriseringen opstod spørgsmål, der guidede tværgående læsning af artiklerne, bl.a.: Hvilken tradition kommer forfatterne fra? Hvilken metode har de brugt? Handler det om undervisning eller uddannelse? Hvem interesserer artiklen sig for - studerende, underviser etc.? Hvilke kendetegn/kriterier bruger de til at vurdere studerendes læring? Er der anbefalinger? På grund af den begrænsede plads kan vi ikke i denne artikel gå nærmere ind i alle spørgsmålene.

\section{Resultater}

Hvad handler teksterne om?

Først vil vi skabe et overblik over de temaer, litteraturen har koncentreret sig om i forbindelse med fagundervisning på et andetsprog ved at gennemgå resultater fra kategoriseringen. 
Dansk litteratur: 46 tekster (se appendix 1)

\begin{tabular}{|l|l|l|l|l|l|l|l|}
\hline Holdninger & $\begin{array}{l}\text { Op- } \\
\text { levelse }\end{array}$ & $\begin{array}{l}\text { Lærings- } \\
\text { udbytte }\end{array}$ & $\begin{array}{l}\text { Under- } \\
\text { visning og } \\
\text { deltagelse }\end{array}$ & $\begin{array}{l}\text { Sproglige } \\
\text { problemer }\end{array}$ & $\begin{array}{l}\text { Sprog } \\
\text { og } \\
\text { identitet }\end{array}$ & $\begin{array}{l}\text { Sprog- } \\
\text { videnskab }\end{array}$ & $\begin{array}{l}\text { Inter- } \\
\text { nationa- } \\
\text { lisering }\end{array}$ \\
\hline 17 & 14 & 1 & 3 & 14 & 3 & 5 & 25 \\
\hline
\end{tabular}

Øvrig skandinavisk litteratur: 35 tekster (se appendix 2)

\begin{tabular}{|l|l|l|l|l|l|l|l|}
\hline Holdninger & $\begin{array}{l}\text { Op- } \\
\text { levelse }\end{array}$ & $\begin{array}{l}\text { Lærings- } \\
\text { udbytte }\end{array}$ & $\begin{array}{l}\text { Under- } \\
\text { visning og } \\
\text { deltagelse }\end{array}$ & $\begin{array}{l}\text { Sproglige } \\
\text { problemer }\end{array}$ & $\begin{array}{l}\text { Sprog } \\
\text { og } \\
\text { identitet }\end{array}$ & $\begin{array}{l}\text { Sprog- } \\
\text { videnskab }\end{array}$ & $\begin{array}{l}\text { Inter- } \\
\text { nationa- } \\
\text { lisering }\end{array}$ \\
\hline 9 & 10 & 3 & 5 & 8 & 0 & 11 & 12 \\
\hline
\end{tabular}

Der viste sig ikke stor ulighed i interesseområderne i den danske litteratur og den øvrige skandinaviske, og denne opdeling viser sig derfor ikke relevant. I de skandinaviske lande, inkl. Danmark, har der særligt været diskussion om brugen af engelsk i uddannelsessektoren jf. kategorien Internationalisering (Phillipson \& Skutnabb-kangas, 1999; Höglin, 2002; Hyltenstam, 2004; Philipson, 2006; Preisler, 2008; Shaw, 2008; Mortensen \& $\mathrm{Ha}$ berland, 2009; Harder, 2009; Bolton \& Kuteeva, 2012; Hultgren, 2014; Kuuteva, 2014). Diskussionerne har især centreret sig om spørgsmål om domænetab og parallelsproglighed. Én definition af domænetab er, at et givent sprog taber et samfundsområde, fx højere uddannelse, til et andet sprog - i dette tilfælde at der ikke tales dansk, og at dansk derfor heller ikke udvikles som sprog for videnskab og akademia. Parallelsproglighed er det begreb, der ligger til grund for sprogpolitikken på de danske universiteter og betyder ideelt set, at to sprog (dansk og engelsk) bruges parallelt inden for $\mathrm{fx}$ det videnskabelige område. Begge diskussioner er særlige for den skandinaviske litteratur og står især stærkt i den danske.

En stor del af den skandinaviske forskning har fokus på holdninger hos undervisere og studerende til at undervise og lære på engelsk (Gunnarsson \& Öhman, 1997; Phillipson \& Skutnabb-Kangas, 1999; Hellekjaer \& Westergaard, 2002; Carroll-Boegh, 2005; Jensen et al., 2009; Tange, 2010; J ensen \& Thøgersen, 2011). Andre har forsøgt at beskrive det sproglige miljø på universitetskurser undervist på engelsk, og det kommer bl.a. til udtryk i studier af kodeskift og placerer sig i kategorien Sprogvidenskab, der markerer sig større i den øvrige skandinaviske litteratur end i den danske (Ljosland, 2008; Björkman, 2010; Söderlundh, 2010). Imidlertid har kun ganske få beskæftiget sig med læringsudbytte. Faktisk havner kun én artikel i Danmark og tre i resten af Skandinavien i denne kategori (Airey, 2009, 2010, Thøgersen \& Airey, 2011, Hellekjær, 2010). 
International litteratur: 131 tekster (se appendix 3)

\begin{tabular}{|l|l|l|l|l|l|l|l|l|}
\hline Holdninger & $\begin{array}{l}\text { Op- } \\
\text { levelse }\end{array}$ & $\begin{array}{l}\text { Lær- } \\
\text { ings- } \\
\text { udbytte }\end{array}$ & $\begin{array}{l}\text { Under- } \\
\text { visning } \\
\text { og del- } \\
\text { tagelse }\end{array}$ & $\begin{array}{l}\text { Sproglige } \\
\text { proble- } \\
\text { mer }\end{array}$ & $\begin{array}{l}\text { Sprog } \\
\text { og } \\
\text { identi- } \\
\text { tet }\end{array}$ & $\begin{array}{l}\text { Sprog- } \\
\text { videnskab }\end{array}$ & $\begin{array}{l}\text { Inter- } \\
\text { natio- } \\
\text { nalise- } \\
\text { ring }\end{array}$ & $\begin{array}{l}\text { Sprog- } \\
\text { kurser }\end{array}$ \\
\hline 38 & 23 & 15 & 13 & 43 & 18 & 7 & 55 & 5 \\
\hline
\end{tabular}

Den internationale litteratur indeholder både forskning fra europæisk og ikke-europæisk kontekst, men udslagsgivende i forhold til interesseområder ser især førstesproget, engelsk eller ikke-engelsk, ud til at være. Kategoriseringen af den internationale litteratur krævede en ekstra kategori, nemlig Sprogkurser, der dækker over effekten af sprogkurser $\mathrm{i}$ forhold til at være rustet til at modtage undervisning på engelsk i et fag, hvor sproget ikke er et eksplicit læringsmål. Dette kan måske hænge sammen med de to kategorier, der ser ud til at dominere, nemlig Sproglige problemer og Internationalisering. I internationaliseringskategorien drejer litteraturen sig primært om udenlandske studerende, og de samme tekster optræder både i denne kategori og i Sproglige problemer. Det lader altså til, at hvor diskussionen om domænetab dominerer den skandinaviske litteratur, er det i den internationale litteratur udenlandske studerende med sproglige problemer, der er centrum for debatten.

Andelen af studier af læringsudbyttet er relativt større i den internationale litteratur. Størstedelen er dog kvantitative sammenligninger af karaktergennemsnit og sprogtests. Det betyder, at det er en relativt snæver forståelse af læringsudbytte, som bliver undersøgt. Sprogtestene siger noget om de studerendes færdigheder men ikke om deres læreproces og læringsudbytte i bredere forstand. Udsagnskraften af karaktererne står og falder med, hvad prøverne måler, og man kan ikke uden videre forudsætte, at et eksamensresultat udtrykker en begrebslig forståelse eller beherskelsen af en kompetence ( $\mathrm{fx}$ Jakobsen et al., 1999), eller at studerende og undervisere har samme opfattelse af bedømmelsen (Fletcher et al., 2012).

\section{Hvad siger teksterne om konsekvenser for læringsudbyttet?}

\section{Forventede konsekvenser af at undervise på et andetsprog}

I det kun ganske få tekster falder i kategorien Læringsudbytte, vil vi først gennemgå de mulige, teoretisk begrundede konsekvenser, det kan have at lære gennem et andetsprog. Derefter vil vi gennemgå enkelte tekster med fokus på empirisk begrundede konsekvenser.

En generel bekymring er, at hvis kompetencen i det sprog, undervisningen foregår på, er dårligere end førstesproget, vil det føre til reduceret faglig kompetence som resultat af enten ufuldstændig forståelse, eller at undervisere tager højde for dette og forsimpler indholdet (Dalton-Puffer, 2011). Desuden kan det synes urimeligt, at studerende skal lære et nyt og svært emne gennem et andetsprog, da det giver dem en dobbelt opgave ift. at mestre både sprog og fagligt indhold (Rolnick, 2000). Denne tankegang kan underbygges af en antagelse af, at når studerende processerer to forskellige opgaver samtidigt, vil deres præstation på den første opgave blive forstyrret af den anden. Dette kaldes inden for teori om kognitiv belastning også for "dual-task". Iflg. denne teori (Sweller et al., 2011) vil undervisning gennem et andetsprog være ineffektiv og forstyrrende for læring, da det forøger den kognitive belastning. Det vil sige, at hvis et individ har begrænset hukommelseskapacitet, og en opgave overstiger den kognitive kapacitet, vil læringen blive forstyrret, og den studerende vil ikke udvikle ny viden. Omvendt argumenterer Cummins (1991) for, at en underliggende dygtighed afgør et individs præstation i 
kognitive og akademiske opgaver både på førstesproget og på andetsproget (se også Gerber et al., 2005).

I enhver undervisningssituation kan man tale om, at der bruges to sprog: et almindeligt talt hverdagssprog og et fagspecifikt videnskabeligt sprog. Forskellen på hverdagssprog og eksempelvis matematisk terminologi fører til, at også førstesprogstalende skal lære et nyt sprog, når de lærer et nyt fag. Östman (1998) foreslår, at fagligt sprog er abstrakt og repræsenterer specielle kommunikative traditioner og forudindtagelser. Halliday og Martin (1993) hævder, at sprog er mere end simpel repræsentation af faglig viden; det er også med til aktivt at facilitere denne viden, og det at lære et fag vil derfor afhænge af at lære fagets sprog. Således kan man argumentere for, at forholdet mellem en studerendes førstesprog og læring ikke er ligefremt.

\section{Empiriske undersøgelser af konsekvenser}

Vi vil nu gennemgå de fire skandinaviske tekster, der optrådte i kategorien Læringsudbytte (Airey, 2009; 2010; Thøgersen \& Airey, 2011; Hellekjær, 2010). For at give et mere nuanceret billede af disse resultater, vil vi supplere med resultater fra den internationale litteratur og fra tekster, der optrådte i kategorien Undervisning og deltagelse.

Aireys ph.d.-afhandling (2009) undersøger på baggrund af klasserumsobservation og interviews læringsmønstre hos studerende på et svensk fysikstudium, bl.a. med fokus på undervisningssprog. Læring er her karakteriseret ved at opnå evne til at bruge semiotiske resurser i overensstemmelse med den disciplinære diskurs. Det viste sig, interessant nok, at de studerende hævdede, at der var få forskelle på at blive undervist på hhv. svensk, førstesproget, og engelsk, andetsproget, og at sprog spillede en ubetydelig rolle for deres læring. Imidlertid kunne videooptagelser af undervisningen vise, at der var flere, vigtige forskelle. Forskellene involverede reduceret mængde spørgsmål, større fokus på notetagning på bekostning af at følge underviserens tankegang, og at de studerende ændrede læringsstrategi for at håndtere sprogskiftet, fx ved at stille spørgsmål efter forelæsningen. De studerende var imidlertid ikke bevidste om ændringerne, før de efterfølgende blev konfronteret med dem. Reduktion i frekvensen af spørgsmål er også observeret af Björkman (2010), og flere undersøgelser, ikke kun i Skandinavien, har vist, at undervisningen bliver relativt mere monologisk og mindre interaktiv, når sproget skiftes til engelsk. Hollandske studier viser ligeledes, at de studerende bliver mere passive i klasserummet (Klaassen, 2001; Vinke, 1995).

I tilknytning til undervisning er den enkelte studerende stillet over for to opgaver, nemlig at forstå og at udtrykke. Airey (2010) fokuserer ikke nødvendigvis på, hvor meget eller lidt de studerende har lært, men hvor godt de udtrykker det, og han lægger sig derved op ad et formidlingsorienteret læringsbegreb. Undersøgelsen sammenligner studerendes forklaring af begreber på to sprog på baggrund af transskriptioner fra interviews lavet med svenske studerende på naturvidenskabelige uddannelser. Resultaterne viser, at engelsk skabte problemer for enkelte studerende, og at de havde svært ved at forklare begreber pga. dårligt engelskniveau. Det er ikke muligt ud fra Aireys undersøgelse at udlede, om problemerne kun var et produkt af dårlige sprogkundskaber, eller om de studerende også havde problemer med at følge undervisningen. Andre studerende i undersøgelsen havde ingen problemer, og for nogen var engelsk det sprog, de forklarede sig bedst på. På baggrund af de resultater konkluderer Airey, at over et vist niveau af engelsk er de studerende lige gode til at forklare begreber på begge sprog uanset undervisningssprog. Dette skal ikke forstås sådan, at de lærer lige så godt, kun at de forklarer sig lige så godt. Dog taler de studerende generelt langsommere på engelsk, også selvom de forstår begrebet, og han anbefaler derfor, at man som underviser tager forbehold for, at langsom tale ikke nødvendigvis er et udtryk for dårlig forståelse. 
Hellekjærs norske studie (2010) behandler læring som forståelse af forelæsninger ved gennem et spørgeskema at undersøge, hvor meget studerende på flere fakulteter fik ud af forelæsninger både på deres førstesprog og på et andetsprog. Hellekjærs resultater viser, at de fleste studerende ikke ser ud til at have seriøse vanskeligheder med at modtage undervisning på et andetsprog. Det er særligt interessant at bemærke, at de problemer, han identificerer i forelæsninger på engelsk, er meget lig de problemer, der kan være med forelæsninger på et førstesprog, dog i en mindre grad. Det synes altså sandsynligt, at problemer med fagspecifik terminologi er de samme på førstesproget som på engelsk, og at læring af terminologien går hånd i hånd med læring af konceptet. Studiet viser yderligere, at de studerende, der ser sig selv arbejde i en international sammenhæng, er dygtigst på engelsk. Vigtigheden, de føler af engelsk for fremtidig karriere, $ø$ ger deres indsats $\mathrm{i}$ at mestre undervisning på et fremmedsprog. Dette minder om resultater fra Nissen (2015).

Der er to sider af en undervisningssituation. Den ene er at blive undervist og den anden at undervise. Begge kan blive påvirket, når undervisningssproget ændres. Et nordisk samarbejde af Thøgersen \& Airey (2011) behandler pædagogiske konsekvenser ved at skifte undervisningssprog, og de behandler derved også den effekt, det kan forventes at have på læringsudbyttet. Undersøgelsen er dels kvantitativ, dels kvalitativ i komparation af naturvidenskabelige underviseres tale både på førstesproget, dansk, og på andetsproget, engelsk. På den ene side analyseres talehastigheden og på den anden talens retoriske stil. Det viser sig, at samme præsentation tager længere tid på andetsproget end på førstesproget. For det første gives studerende mere tid til at overveje en given information. Faktisk gives de ca. 50\% længere tid til at forstå og behandle sætningen. For det andet bliver de studerende præsenteret for et ekstra fagcentralt synonym til at forklare begrebet, og der bygges på den måde stærkere forbindelser mellem den centrale terminologi. De studerende, der bliver undervist på dansk, præsenteres for mere verbalt materiale, idet underviserne bruger flere ord og flere måder til at forklare begrebet på. Modsat hvad man kunne forestille sig, er det i denne undersøgelse ikke undervisningen på engelsk, der har et mindre specifikt ordforråd, men undervisningen på førstesproget. Det skyldes, at de engelske forelæsninger har en mere formel stil tæet på tekstbogssprog, hvor de danske har mere uformelle sprogstrukturer (se også Thøgersen, 2013). Thøgersen \& Airey argumenterer for, at undenviseren måske er nødt til at ændre pædagogisk stil, fordi det engelsk, hun har adgang til, er tekstbogsengelsk. I det tilfælde vil underviseren i et pædagogisk perspektiv være mere fattig på engelsk. Dog mener de også, at det er tænkeligt, at de studerende finder det lettere at håndtere en formel beskrivelse gentaget flere gange end det samme indhold formuleret på forskellige måder i hverdagssprog.

Hvis vi kigger uden for Europa, kan et sydafrikansk studie af Paxton (2009) give indsigt i, hvordan studerende håndterer læringssituationen på et andetsprog i en undersøgelse, der ligesom Aireys (2010) beder studerende forklare begreber på to sprog og i øvrigt give eksempler på, hvordan man bruger dem. I afrikanske sprog er der ord inden for bl.a. akademiske domæner, der ikke er en etableret del af sproget, fordi der ikke er udviklet fagterminologi. Når studerende skal lære et givent fags sprog, flyttes de fra hverdagssprog til et specialiseret domæne, og det er et afgørende skridt i undervisnings- og læreprocesser. Studiet viser, at de studerende oversætter begreber til deres førstesprog for at forstå dem, men hvis der ikke findes et ord på sproget, finder de det betydningsmæssigt nærmest beslægtede. Da ordene ikke betyder helt det samme, făr de imidlertid en utilstrækkelig forståelse af begrebet, og i værste fald misforstår de. Nogle af de svenske studerende syntes at bruge samme strategi, idet de brugte det, der kaldes en false friend, dvs. et ord, der ligner ordet på deres førstesprog, men som har en anden betydning på det andet sprog. 
Hvis det at oversætte begrebet imidlertid ikke syntes tilstrækkeligt for de sydafrikanske studerendes forståelse, fandt de, at den eneste løsning var at huske ordet uden at forstå det og derved ty til overfladelæring (Biggs \& Tang, 2011). Paxtons studie konkluderer altså, at læring af økonomiske koncepter bliver begrænset af kun at bruge andetsproget, og at undervisere måske ikke er opmærksomme på, at skriftligt arbejde kan gemme på misforståelser, idet studerende ikke fuldt forstår den engelske tekst, men blot memorerer den. I følge Paxton kan en løsning være at lade de studerende bruge begge sprog i diskussioner med ligesindede, og at de derved måske kan opnå en dybere forståelse af begrebet, end hvis kun det ene sprog bruges.

I den internationale litteratur peger Gerber et al. (2005), Klaassen (2001), Neville-Barton \& Barton (2005) og Vinke (1995) på negative korrelationer mellem faglig præstation og ændring af undervisningssprog, og New Zealandske studier viser, at studerende undervist på et andetsprog præsterer $10 \%$ dårligere end studerende undervist på førstesprog (Barton \& Neville-Barton, 2003; Neville-Barton \& Barton, 2005). Lignende forhold findes til en vis grad hos Gerber et al. (2005) i et studie af afrikaans-talendes læring af matematik på engelsk, men hvor den matematiske evne dog viser sig vigtigere for præstationen end sproglige kompetencer. I Klaassens studie (2001) udlignede forskellene sig over tid, og ingen af ovenstående studier kan sige noget endegyldigt om, hvorvidt læringsudbyttet falder, når undervisningssproget skiftes.

\section{Diskussion og konklusion}

I første del af reviewet viste vi en forskel i temaer i skandinaviske og i internationale studier af undervisning på engelsk. Hvor de skandinaviske lande var optaget af domænetab, fokuserede den internationale litteratur på sprogvanskeligheder og internationalisering. Forskellene afspejler de nationale udgangspunkter: For de nordiske lande betyder internationaliseringen et skift fra nationalsprog til engelsk, og det giver anledning til overvejelser. For engelsktalende lande betyder internationalisering flere studerende med andre sproglige forudsætninger.

Den skandinaviske litteraturs vægt på holdninger og oplevelse af undervisning på engelsk kan måske skyldes en interesse for de aktører, som skal forvalte ændringen af undervisningssprog og måske også en interesse for de politiske sider af sagen. Mens den skandinaviske litteratur indeholder indirekte undersøgelse af læringsudbyttet gennem studier af de studerendes måde at deltage i undervisningen på (jf. senere), så er det imidlertid påfaldende få studier, som direkte undersøger det konkrete læringsudbytte. Det kan skyldes, at det er metodisk vanskeligt at gennemføre kontrollerede undersøgelser af sprogets betydning for læringsudbytte, som kan indfange de mere komplekse, kompetenceorienterede læringsmål, som ofte vil findes på videregående uddannelser. Det kan også hænge sammen med, at der i Skandinavien ikke er en stærk forskningstradition for at måle læringsudbytte, netop fordi der er en bekymring for forsimpling af læringsmålet for at gøre det målbart. Selv om det er en reel bekymring, giver det omvendt et problem i diskussionen af, hvilke konsekvenser fx skift i undervisningssproget har for de studerende.

Vægtningen af den skandinaviske litteratur skal også ses i lyset af relativt få studier og af, at en del af studierne er gennemført af de samme forfattere, som måske har bestemte interesseområder. Tallene kan således både afspejle et uudviklet forskningsfelt og en manglende interesse for læringsudbytte.

De få empiriske undersøgelser af læringsudbytte, selv hvis man inddrager den internationale litteratur, giver ikke noget klart svar på spørgsmålet om, hvilken konkret betydning undervisning på et andetsprog har for læringsudbyttet. Klaassens studie antyder, at læringsudbyttet falder, når man skifter undervisningssprog, men det er værd at bemærke, at det udligner sig over tid, efterhånden som de studerende vænner sig til sprogskiftet. 
Airey og kolleger siger ikke noget direkte om læringsudbytte, men ud fra de effekter på de studerendes deltagelse og undervisernes praksis, som undersøgelserne afdækker, kan man sige, at det er overvejende sandsynligt, at det sproglige medium har en indirekte betydning for de studerendes læringsudbytte. Det hænger sammen med, at de praksisser, Airey m.fl. finder, i anden universitetspædagogisk forskning er knyttet til mere overfladisk læring (fx Prosser and Trigwell, 1999).Omvendt betyder det også, at nogle af de forhold, som findes i den engelsksprogede undervisning, også findes i undervisning på førstesproget. De studerende gør, hvad de kan for at klare kurset uafhængigt af kvaliteten af undervisning. Undervisning på et andetsprog fremhæver altså til en vis grad problemer, der måske allerede er der.

Paxtons sydafrikanske studie understreger, at sprog hænger sammen med kultur, og at det derfor ikke blot er et spørgsmål om sprogfærdighed - en pointe som er parallel med Halliday og Martins sprogsyn. De studerendes forståelsesstrategier i oversættelsen mellem forskellige faglige sprog, men også mellem forskellige erfaringsverdener kan have betydning for, hvor korrekt de studerende forstår det faglige indhold. På den måde handler undervisning på andetsprog også om at være opmærksom på kulturelle forhold, som spiller ind på de studerendes forståelse.

Samlet set vil vi pege på to konklusioner og perspektiver fra dette review. Det første er, at diskussionen om brug af engelsk som undervisningssprog på videregående uddannelser kræver en langt mere nuanceret forståelse end engelsksproglige kompetencer. Sprog er knyttet til kultur og identitet og er forbundet med forståelse på flere måder end gennem semantikken. Sproget er også knyttet til de studerendes og undervisernes praksisser i læringsrummet og dermed til den måde, hvorpå disse praksisser understøtter eller hæmmer læring. Diskussionen kræver nuancer.

Det andet er, at der er brug for flere undersøgelser, som målrettet og nuanceret søger at afdække de studerendes læringsudbytte. Sådanne undersøgelser er komplekse, fordi så mange forhold påvirker læringsudbyttet. Det gælder ikke kun studier af effekten af undervisningssprog, men af undervisning i det hele taget. Der er derfor brug for studier, som med forskellige metoder undersøger læringsudbyttet i bred forstand. Sådanne studier vil ikke kunne formulere ét svar på, hvilken betydning undervisningssproget har; men det vil kunne kvalificere diskussionen, og i lyset af omfanget af engelsksproget undervisning på danske uddannelser vil det være meget relevant. Et relevant aspekt er, om en ændring i undervisningssproget kan have forskellig betydning i forskellige fagområder. En stor del af de nordiske studier har undersøgt naturvidenskabelige uddannelser, men det er muligt, at forskelle i læringsindhold og undervisningstraditioner kan betyde, at man ikke nødvendigvis uden videre kan overføre resultater fra ét fagområde til et andet. Tilsvarende kan der være forskelle i konsekvensen på tværs af kulturer - herunder undervisningskulturer - som svækker undersøgelsernes udsagnskraft. Flere, nuancerede og sammenlignende studier vil derfor være kærkomne.

Som underviser kan man holde sig for øje, at selvom studerende (og undervisere) skulle mene, at det er uden betydning at kunne tale et fremmedsprog, så gør det en forskel for nuancerne og følelsen af sikkerhed. Det vil kunne afhjælpes ved en opmærksomhed på at skabe et trygt læringsrum, at give de studerende muligheder for at tale i mindre grupper, åbne for at bruge modersmålet også og ved at forvente langsommere og mere tøvende tale - som ikke skal forveksles med faglig usikkerhed.

Tilsvarende bliver studerende mere tilbøjelige til at blive mere passive og anlægge overfladestrategier. Det taler for en (endnu mere) bevidst brug af studenterinddragelse, små øvelser og gruppediskussioner, refleksion, tænkeskrivning osv. - dvs. teknikker som tilskynder de studerende til at arbejde aktivt med indholdet og tilbyder tid og rum til at gøre det. 
Væsentligst er det dog, at underviseren er opmærksom på, at der er forskel på at undervise på modersmålet og på engelsk - også selv om det ikke kan afgøres præcist, hvilken betydning forskellen har.

Camilla Falk Rønne Nissen er ph.d.-studerende i Dansk ved Institut for Nordiske Studier og Sprogvidenskab. Hendes ph.d.-projekt handler om de sproglige og pæedagogiske konsekvenser, som internationalisering af universitetet medfører. I 2015 blev Camillas empirisk baserede speciale udgivet af Center for Internationalisering og Parallelsproglighed. Her findes et etnografisk studie af det sproglige miljø på to engelsksprogede kurser på Københavns Universitet.

Lars Ulriksen er professor i Naturfagenes Uddannelsessociologi ved Institut for Naturfagenes Didaktik på Københavns Universitet. Hans primæere forskningsinteresse er mødet mellem deltagerne og uddannelser, herunder uddannelsernes opbygning, de undervisningsformer som bruges, og hvad det forudsætter hos deltagerne - ikke mindst hos de studerende. Han har undervist på adjunktpædagogikum siden 1999 og udgav i 2014 bogen God undervisning på de videregående uddannelser (Fryden/und).

\section{Litteratur}

Airey, J. (2009). Science, Language and Literacy: Case Studies of Learning in Swedish University Physics. (PhD thesis). Uppsala: Acta Universitatis Upsaliensis. Retrieved from http://www.diva-portal.org/smash/get/diva2:173193/FULTEXT01.pdf.

Airey, J. (2010). The ability of students to explain science concepts in two languages. Hermes - Journal of Language and Communication Studies ,45, 35-49.

Barton, B. \& Neville-Barton, P. (2003). Language issues in undergraduate mathematics: Report of two studies. New Zealand Journal of Mathematics, 32, 19-28.

Biggs, J. B. \& Tang, C. (2011). Teaching for Quality Learning at University. What Students do (3. Edition). Maidenhead: Society for Research into Higher Education \& Open University Press, McGraw-Hill Education.

Björkman, B. (2010). Spoken Lingua Franca English at a Swedish Technical University: An Investigation of Form and Communicative Effectiveness. Unpublished PhD thesis. Stockholm: Stockholm University.

Bolton, K. \& Kuteeva, M. (2012). English as an academic language at a Swedish university: Parallel language use and the "threat" of English. Journal of Multilingual and Multicultural Development, 33(5), 429-447.

Carroll-Boegh, A. (2005). Internationalisation and teaching through English: A Danish perspective. Educate, 5(2), 19-30.

Cummins, J. (1991). Interdependence of first and second language proficiency in bilingual children. I: E. Bialystok (red.): Language processing in bilingual children, 70-89. Cambridge, UK: Cambridge University Press.

Dalton-Puffer, C. (2011). Content and language integrated learning: From practice to principles? Annual Reviews of Applied Linguistics, 31, 182-204.

Fletcher, R. B., Meyer, L. H., Anderson, H., J ohnston, P. \& Rees, M. (2012). Faculty and students conceptions of assessment in higher education. Higher Education, 64(1), 119-133. doi: 10.1007/s10734-011-9484-1.

Gerber, A., J., Engelbrecht, Harding, A. \& Rogan, J. (2005). The influence of second language teaching on undergraduate mathematics performance. Mathematics Education Research Journal,17, 3-21.

Gunnarsson, B.-L. \& Öhman, K. (1997). Det internationaliserade universitetet. En studie av bruket av engelska och andra främmande språk vid Uppsala Universitet. TeFa 16. Uppsala: Uppsala universitet, Department of Scandinavian Languages.

Halliday, M. A. K. \& Martin, J. R. (1993). Writing Science: Literacy and Discursive Power. London: Falmer. 
Harder, P. (red.) (2009). Angles on the English-Speaking World: English in Denmark; Language Policy, Internationalization and University Teaching. København: Museum Tusculanum.

Hellekjær, G. O. (2010). Language matters: Assessing lecture comprehension in Norwegian English-medium higher education. I: C. Dalton-Puffer, T. Nikula \& U.J .B. Smit (red.): Language Use and Language Learning in CLIL Classrooms, 233258. Amsterdam: J ohn Benjamins.

Hellekjær, G. O. \& Westergaard, M. R. (2002). An exploratory survey of content learning through English at Scandinavian universities. I: A. M. Simensen (red.): Teaching and learning foreign languages issues and ideas, 47-61. Oslo: Unipub.

Höglin, R. (2002). Engelska språket som hot och tillgång i Norden. Köpenhamn: Nordiska ministerrådet.

Holmen, Anne (2006): Finding a voice in a second language. I: Ø. Dahl, I. J ensen \& P. Nynäs (red.): Bridges of Understanding. Perspectives on Intercultural Communication. Oslo: Unipub forlag.

Hultgren, A. K. (2014). Whose parallellingualism? Overt and covert ideologies in Danish university language policies. Multilingua. Journal of cross-cultural and interlanguage communication, 33(1-2), 61-87.

Hyltenstam, K. (2004). Engelskan, skolans språkundervisning och svensk språkpolitik. I: O. Josephson \& B. Lindgren (red.): Engelskan i Sverige. Språkval i utbildning, arbete och kulturliv, 36-110. Stockholm: Svenska Språknämnden.

Illeris, K. (2006). Læring (2. reviderede udg.). Frederiksberg: Roskilde Universitetsforlag.

Jakobsen, A., Rump, С. Ø., Clemmensen, T. \& May, M. (1999). Kvalitetsudviklingsprojektet "Faglig Sammenhæeng" Hovedrapport (Vol. 1). Lyngby: Center for Didaktik og Metodeudvikling, Danmarks Tekniske Universitet.

J ensen, C. \& Thøgersen, J. (2011). Danish University lecturers' attitudes towards English as the medium of instruction. /bérica, 22, 13-34.

J ensen, C., Stæhr, L. S., Thøgersen, J. \& Nielsen, J. Ø. (2009). Underviseres holdninger til engelsk som undervisningssprog: En spørgeskemaundersøgelse på Københavns Universitet. Center for Internationalisering og Parallelsproglighed. København: Museum Tusculanum . http://cip.ku.dk/forskning/publikationer/.

Klaassen, R. (2001). The International University Curriculum: Challenges in English medium Engineering Education. Unpublished Doctoral Thesis, Delft University of Technology.

Kuteeva, M. (2014). The parallel language use of Swedish and English: The question of "nativeness" in university policies and practices. Journal of Multilingual and Multicultural Development, 35(4), 332-344.

Lauridsen, K. (2015). International programmes or English medium instruction. Præsentation på Dansk Universitetspædagogisk Netværks Konference 2015

Ljosland, R. (2008). Lingua franca, prestisjespråk og forestilt fellesskap: Om engelsk som akademisk språk i Norge. Et kasusstudium i bred kontekst. Unpublished PhD thesis. Norwegian University of Science and Technology.

Mortensen, J. \& Haberland, H. (2009). Sprogvalg på danske universiteter i historisk perspektiv. Sprogforum, 46, 8-13.

Mortensen, J. \& Haberland, H. (2012). English - the new latin of academia? Danish universities as a case. International Journal of the Sociology of Language, 216, 175-197.

Neville-Barton, P. \& Barton, B. (2005). The Relationship between English Language and Mathematics Learning for Non-native Speakers. Wellington: Teaching and Learning Research.

Nissen, C. F. R. (2015). En parallelsproglig virkelighed - et etnografisk studie af sprogbrugsmønstre på to kurser udbudt på engelsk på SCIENCE og SUND, Københavns Universitet. Københavnerstudier i tosprogethed. Studier i Parallelsproglighed, bind C7. København: Københavns Universitet, Humanistisk Fakultet. 
Paxton, M. I. J . (2009). "It's easy to learn when you using your home language but with English you need to start learning language before you get to the concept": Bilingual concept development in an English medium university in South Africa. Journal of Multilingual and Multicultural Development, 3044), 345-359.

Phillipson, R. (2006). English, a cuckoo in the European higher education nest of languages? European Journal of English Studies, 101), 13-32.

Phillipson, R. \& Skutnabb-Kangas, T. (1999). Englishisation: One dimension of globalisation. I: D. Graddol \& U. H. Meinhof (red.): English in a Changing World. AlLA Review, 13, 19-36. Guilford: AlLA.

Prosser, M. \& Trigwell, K. (1999). Understanding Learning and Teaching. The Experience in Higher Education. Buckingham: Open University Press.

Preisler, B. (2008). Teaching in a foreign language: Linguistic performance and academic authority in the international university. I: H. Haberland, J. Mortensen, A. Fabricius, B. Preisler, K. Risager \& S. Kjærbeck (red.): Higher Education in the Global Village. Department of Culture and I dentity, Roskilde University

Rolnick, M. (2000). Current issues and perspectives on second language learning of science. Studies in Science Education, 35, 9-121.

Shaw, P. (2008). Engelska som lingua franca och som internationellt vetenskapsspråk. I: E. Jansson (red.): Vetenskapsengelska - med svensk kvalitet?, 21-34. Stockholm: Språkrådet.

Söderlundh, H. (2010). Internationella universitet - lokala språkval. Om bruket av talad svenska i engelskspråkiga kursmiljöer. Uppsala: Institutionen för Nordiska Språk, Uppsala Universitet.

Sweller, J, Ayres, P. \& Kalyuga, S. (2011). Cognitive Load Theory. New York, NY: Springer.

Tamir, P. (1998). Assessment and evaluation in science education: Opportunities to learn and outcomes. I: B. J. Fraser \& K. G. Tobin (red.): International Handbook of Science Education, 761-789. Dordrecht/Boston/London: Kluwer Academic Publishers.

Tange, H. (2010). Caught in the Tower of Babel: University lecturers' experiences with internationalization. Journal of Language and International Communication, 10, 137-49.

Thøgersen, J. \& Airey, J. (2011). Teaching undergraduate science in Danish and in English: A comparison of speaking rate and rhetorical style. English for Specific Purposes 30, 209-221.

Thøgersen, J. (2013). Stylistic and pedagogical consequences of university teaching in English in Europe. I: H. Haberland, D. Lønsmann \& B. Preisler (red.): Language Alternation, Language Choice, and Language Encounter in International Tertiary Education. Berlin: Springer.

Ulriksen, Lars (2014). God undervisning på de videregående uddannelser. Frederiksberg: Frydenlund.

Vinke, A. A. (1995). English as the Medium of Instruction in Dutch Engineering Education. Unpublished Doctoral Thesis, Delft University of Technology.

Östman, L. (1998). How companion meanings are expressed by science education discourse. I: D. Roberts \& L. Östman (red.): Problems of Meaning in Science Education, 54-70. New York: Teachers College Press. 
Appendix 1: Dansk litteratur

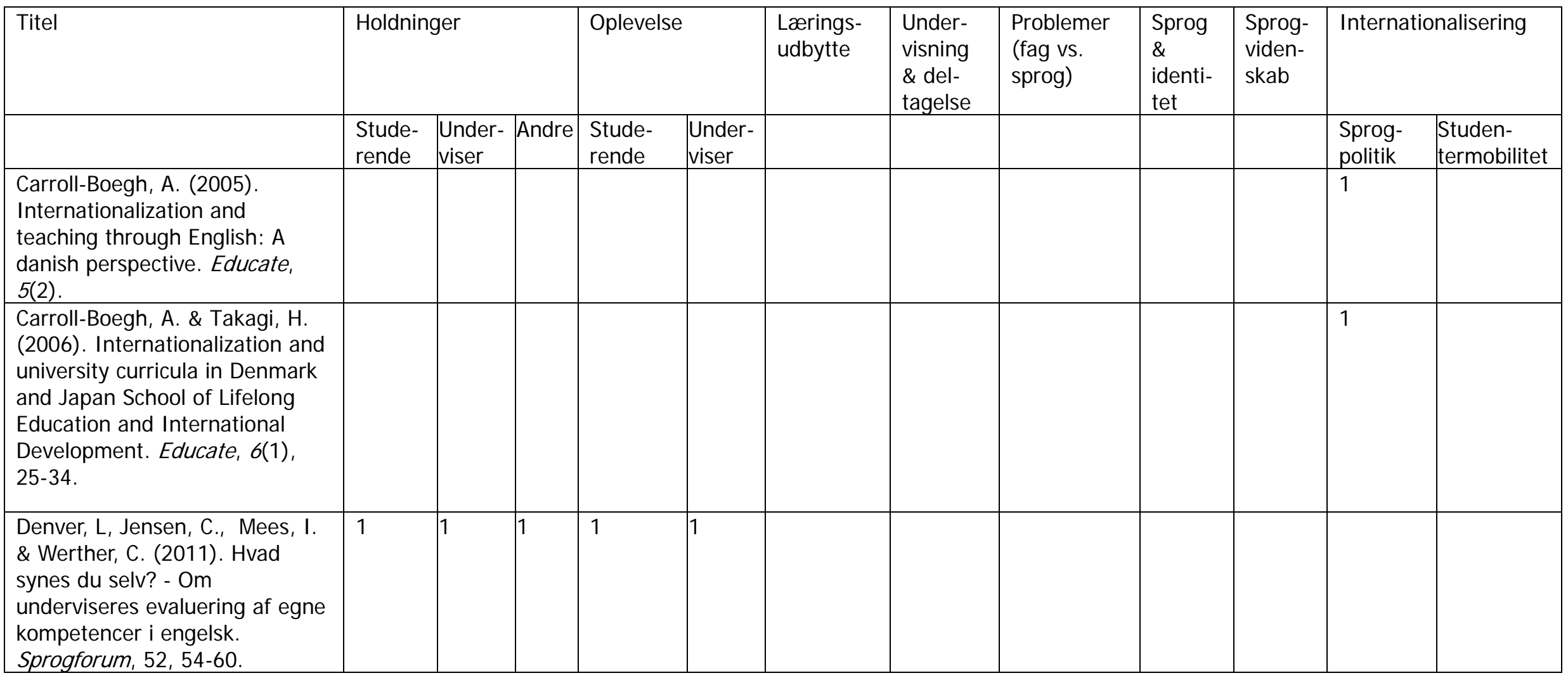




\begin{tabular}{|c|c|c|c|c|c|c|c|c|c|c|c|c|}
\hline \multirow[t]{2}{*}{ Titel } & \multicolumn{3}{|c|}{ Holdninger } & \multicolumn{2}{|c|}{ Oplevelse } & \multirow{2}{*}{$\begin{array}{l}\text { Lærings- } \\
\text { udbytte }\end{array}$} & \multirow{2}{*}{$\begin{array}{l}\text { Under- } \\
\text { visning \& } \\
\text { deltagelse }\end{array}$} & \multirow{2}{*}{$\begin{array}{l}\text { Problem- } \\
\text { er (fag vs. } \\
\text { sprog) }\end{array}$} & \multirow{2}{*}{$\begin{array}{l}\text { Sprog \& } \\
\text { identi- } \\
\text { tet }\end{array}$} & \multirow{2}{*}{$\begin{array}{l}\text { Sprog- } \\
\text { viden- } \\
\text { skab }\end{array}$} & \multicolumn{2}{|c|}{ Internationalisering } \\
\hline & $\begin{array}{l}\text { Stude- } \\
\text { rende }\end{array}$ & $\begin{array}{l}\text { Under- } \\
\text { viser }\end{array}$ & Andre & $\begin{array}{l}\text { Stude- } \\
\text { rende }\end{array}$ & $\begin{array}{l}\text { Under } \\
\text {-viser }\end{array}$ & & & & & & $\begin{array}{l}\text { Sprog- } \\
\text { politik }\end{array}$ & \begin{tabular}{|l|} 
Studen- \\
termobilitet
\end{tabular} \\
\hline
\end{tabular}




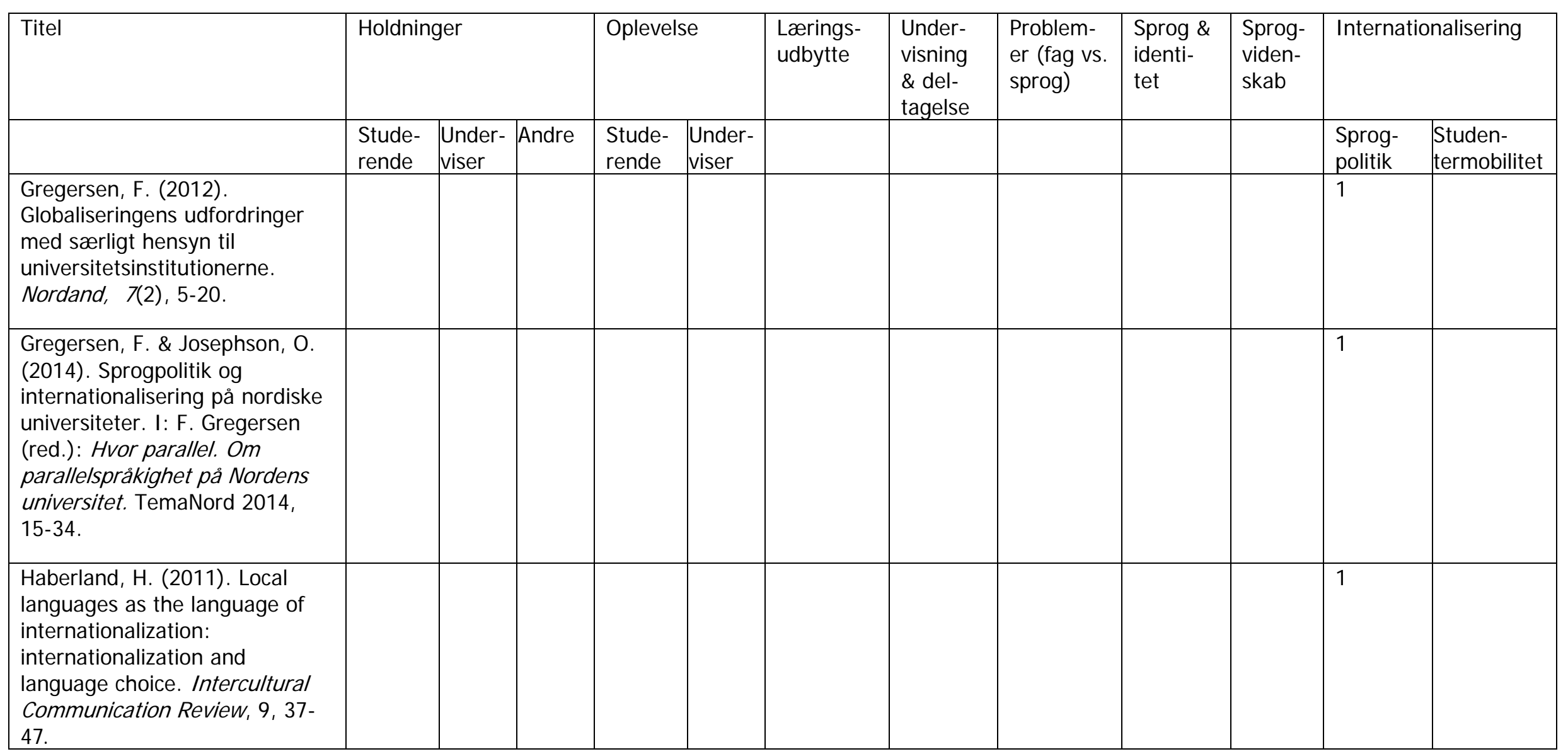




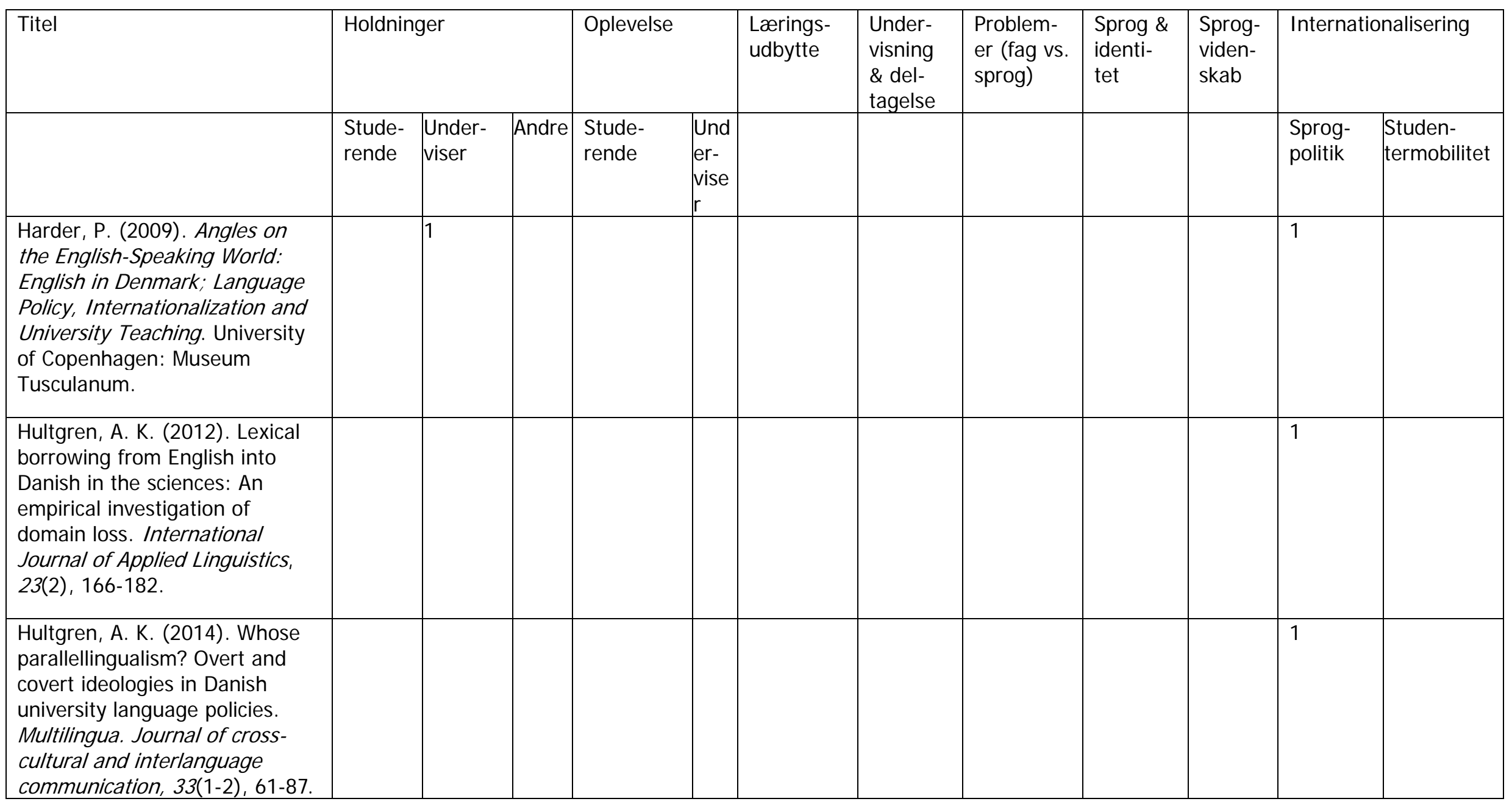




\begin{tabular}{|c|c|c|c|c|c|c|c|c|c|c|c|c|}
\hline \multirow[t]{2}{*}{ Titel } & \multicolumn{3}{|c|}{ Holdninger } & \multicolumn{2}{|c|}{ Oplevelse } & \multirow{2}{*}{$\begin{array}{l}\text { Lærings- } \\
\text { udbytte }\end{array}$} & \multirow{2}{*}{$\begin{array}{l}\text { Under- } \\
\text { visning } \\
\& \text { del- } \\
\text { tagelse } \\
\end{array}$} & \multirow{2}{*}{$\begin{array}{l}\text { Problem- } \\
\text { er (fag vs. } \\
\text { sprog) }\end{array}$} & \multirow{2}{*}{$\begin{array}{l}\text { Sprog \& } \\
\text { identi- } \\
\text { tet }\end{array}$} & \multirow{2}{*}{$\begin{array}{l}\text { Sprog- } \\
\text { viden- } \\
\text { skab }\end{array}$} & \multicolumn{2}{|c|}{ Internationalisering } \\
\hline & $\begin{array}{l}\text { Stude- } \\
\text { rende }\end{array}$ & $\begin{array}{l}\text { Under- } \\
\text { viser }\end{array}$ & Andre & $\begin{array}{l}\text { Stude- } \\
\text { rende }\end{array}$ & $\begin{array}{l}\text { Under } \\
\text {-viser }\end{array}$ & & & & & & $\begin{array}{l}\text { Sprog- } \\
\text { politik }\end{array}$ & $\begin{array}{l}\text { Studen- } \\
\text { termobi-litet }\end{array}$ \\
\hline $\begin{array}{l}\text { Hultgren, A. K., Gregersen, F. \& } \\
\text { Thøgersen, J. (red.) (2014). } \\
\text { English in Nordic Universities: } \\
\text { Ideologies and Practices. } \\
\text { Amsterdam: J ohn Benjamins } \\
\text { Publishing Company. }\end{array}$ & & & & & & & & & & 1 & 1 & \\
\hline $\begin{array}{l}\text { J akobsen, A. S. (2010). "Ellers } \\
\text { er det bare lige ud af } \\
\text { landevejen" - en } \\
\text { interviewundersøgelse af ti } \\
\text { underviseres holdninger til og } \\
\text { erfaringer med engelsksproget } \\
\text { undervisning ved Det } \\
\text { Biovidenskabelige Fakultet, KU. } \\
\text { (Studier i Parallelsproglighed, } \\
\text { bind C2, Københavnerstudier i } \\
\text { Tosprogethed). København: } \\
\text { Københavns Universitet, } \\
\text { Humanistisk fakultet. }\end{array}$ & & 1 & & & 1 & & & & & & & \\
\hline
\end{tabular}




\begin{tabular}{|c|c|c|c|c|c|c|c|c|c|c|c|c|}
\hline \multirow[t]{2}{*}{ Titel } & \multicolumn{3}{|c|}{ Holdninger } & \multicolumn{2}{|c|}{ Oplevelse } & \multirow{2}{*}{$\begin{array}{l}\text { Lærings- } \\
\text { udbytte }\end{array}$} & \multirow{2}{*}{$\begin{array}{l}\text { Under- } \\
\text { visning } \\
\& \text { del- } \\
\text { tagelse }\end{array}$} & \multirow{2}{*}{$\begin{array}{l}\text { Problem- } \\
\text { er (fag vs. } \\
\text { sprog) }\end{array}$} & \multirow{2}{*}{$\begin{array}{l}\text { Sprog \& } \\
\text { identi- } \\
\text { tet }\end{array}$} & \multirow{2}{*}{$\begin{array}{l}\text { Sprog- } \\
\text { viden- } \\
\text { skab }\end{array}$} & \multicolumn{2}{|c|}{ Internationalisering } \\
\hline & $\begin{array}{l}\text { Stude- } \\
\text { rende }\end{array}$ & $\begin{array}{l}\text { Under- } \\
\text { viser }\end{array}$ & Andre & $\begin{array}{l}\text { Stude- } \\
\text { rende }\end{array}$ & $\begin{array}{l}\text { Under- } \\
\text { viser }\end{array}$ & & & & & & $\begin{array}{l}\text { Sprog- } \\
\text { politik }\end{array}$ & \begin{tabular}{|l|} 
Studen- \\
termobilitet
\end{tabular} \\
\hline $\begin{array}{l}\text { Jensen, C. \& Thøgersen, J. } \\
\text { (2011). Danish university } \\
\text { lecturers' attitudes towards } \\
\text { English as the medium of } \\
\text { instruction. / bérica, 22, 13-34. }\end{array}$ & & 1 & & & & & & & & & & \\
\hline $\begin{array}{l}\text { J ensen, C., Denver, L. et al. } \\
\text { (2013). Students' attitudes to } \\
\text { lecturers' English in English- } \\
\text { medium higher education in } \\
\text { Denmark, NJ ES (Online), 13(1), } \\
\text { 87-112. }\end{array}$ & 1 & & & & & & & & & & & \\
\hline
\end{tabular}




\begin{tabular}{|c|c|c|c|c|c|c|c|c|c|c|c|c|}
\hline \multirow[t]{2}{*}{ Titel } & \multicolumn{3}{|c|}{ Holdninger } & \multicolumn{2}{|c|}{ Oplevelse } & \multirow{2}{*}{$\begin{array}{l}\text { Lærings- } \\
\text { udbytte }\end{array}$} & \multirow{2}{*}{$\begin{array}{l}\text { Under- } \\
\text { visning } \\
\& \text { del- } \\
\text { tagelse }\end{array}$} & \multirow{2}{*}{$\begin{array}{l}\text { Problem- } \\
\text { er (fag vs. } \\
\text { sprog) }\end{array}$} & \multirow{2}{*}{$\begin{array}{l}\text { Sprog \& } \\
\text { identi- } \\
\text { tet }\end{array}$} & \multirow{2}{*}{$\begin{array}{l}\text { Sprog- } \\
\text { viden- } \\
\text { skab }\end{array}$} & \multicolumn{2}{|c|}{ Internationalisering } \\
\hline & $\begin{array}{l}\text { Stude- } \\
\text { rende }\end{array}$ & $\begin{array}{l}\text { Under- } \\
\text { viser }\end{array}$ & Andre & $\begin{array}{l}\text { Stude- } \\
\text { rende }\end{array}$ & $\begin{array}{l}\text { Under- } \\
\text { viser }\end{array}$ & & & & & & $\begin{array}{l}\text { Sprog- } \\
\text { politik }\end{array}$ & \begin{tabular}{|l} 
Studen- \\
termobilitet
\end{tabular} \\
\hline $\begin{array}{l}\text { Jensen, C., Stæhr, L. S. \& } \\
\text { Thøgersen, J. (2009). Har ældre } \\
\text { universitetsundervisere flere } \\
\text { problemer med undervisning på } \\
\text { engelsk?. Sprogforum, } 46 .\end{array}$ & & & & & 1 & & & & & & & \\
\hline & & & & & & & & & & & & \\
\hline
\end{tabular}




\begin{tabular}{|c|c|c|c|c|c|c|c|c|c|c|c|c|}
\hline \multirow[t]{2}{*}{ Titel } & \multicolumn{3}{|c|}{ Holdninger } & \multicolumn{2}{|c|}{ Oplevelse } & \multirow{2}{*}{$\begin{array}{l}\text { Lærings- } \\
\text { udbytte }\end{array}$} & \multirow{2}{*}{$\begin{array}{l}\text { Under- } \\
\text { visning } \\
\& \text { del- } \\
\text { tagelse }\end{array}$} & \multirow{2}{*}{$\begin{array}{l}\text { Problem- } \\
\text { er (fag vs. } \\
\text { sprog) }\end{array}$} & \multirow{2}{*}{$\begin{array}{l}\text { Sprog \& } \\
\text { identi- } \\
\text { tet }\end{array}$} & \multirow{2}{*}{$\begin{array}{l}\text { Sprog- } \\
\text { viden- } \\
\text { skab }\end{array}$} & \multicolumn{2}{|c|}{ Interna-tionalisering } \\
\hline & $\begin{array}{l}\text { Stude- } \\
\text { rende }\end{array}$ & $\begin{array}{l}\text { Under- } \\
\text { viser }\end{array}$ & Andre & $\begin{array}{l}\text { Stude- } \\
\text { rende }\end{array}$ & $\begin{array}{l}\text { Under } \\
\text {-viser }\end{array}$ & & & & & & $\begin{array}{l}\text { Sprog- } \\
\text { politik }\end{array}$ & $\begin{array}{l}\text { Studen- } \\
\text { termobilitet }\end{array}$ \\
\hline $\begin{array}{l}\text { Kling, J. M. \& Stæhr, L. S. } \\
\text { (2011). Assessment and } \\
\text { assistance: Developing } \\
\text { university lecturers' language } \\
\text { skills through certification } \\
\text { feedback. I: R. Cancino, K. } \\
\text { Jæger \& L. Dam (red.): Policies, } \\
\text { Principles, Practices: New } \\
\text { Directions in Foreign Language } \\
\text { Education in the Era of } \\
\text { Educational Globalization, 213- } \\
\text { 245. Newcastle upon Tyne, UK: } \\
\text { Cambridge Scholars Press. }\end{array}$ & & & & & & & & 1 & & 1 & & \\
\hline
\end{tabular}




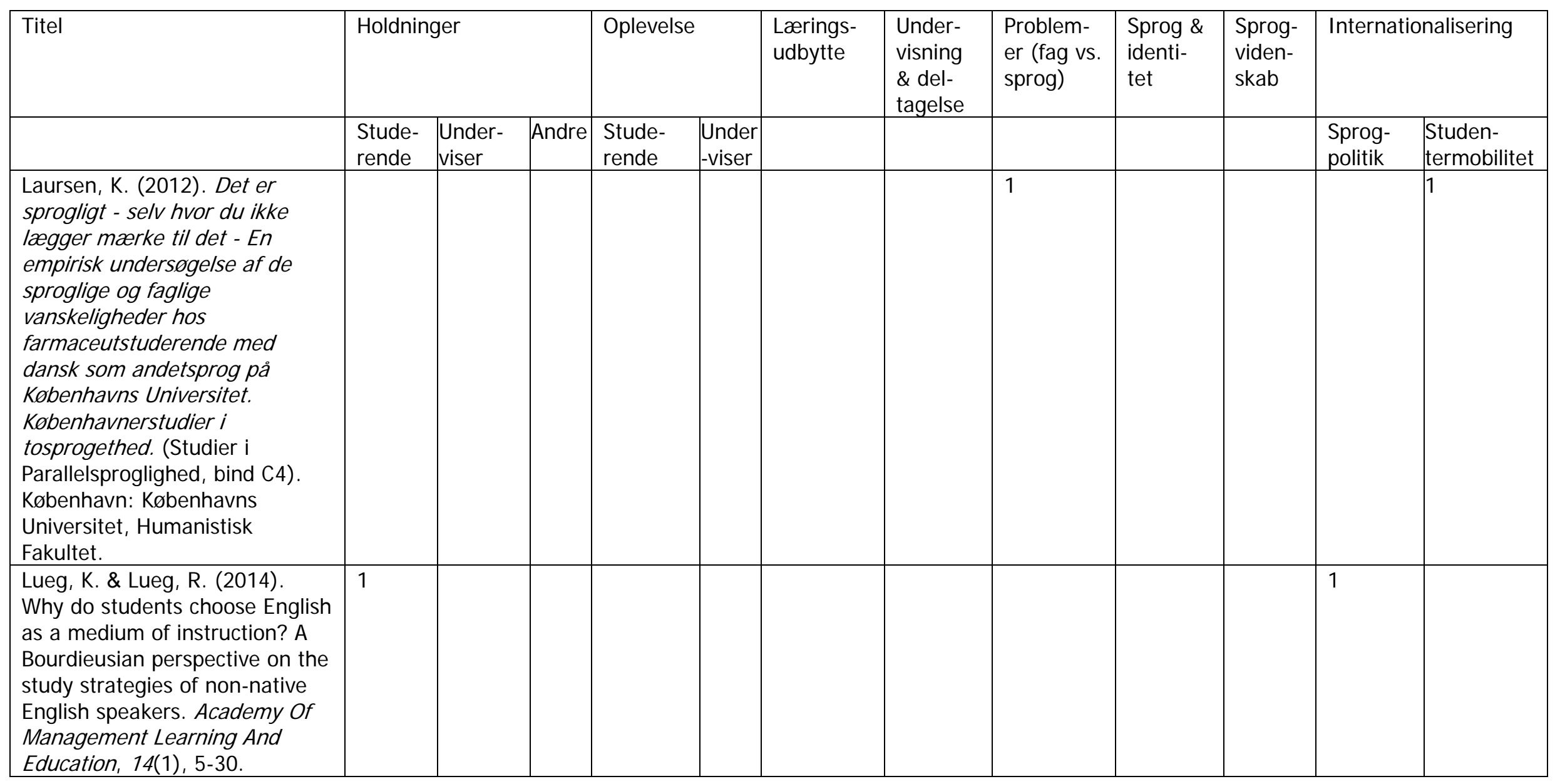




\begin{tabular}{|c|c|c|c|c|c|c|c|c|c|c|c|c|}
\hline \multirow[t]{2}{*}{ Titel } & \multicolumn{3}{|c|}{ Holdninger } & \multicolumn{2}{|c|}{ Oplevelse } & \multirow{2}{*}{$\begin{array}{l}\text { Lærings- } \\
\text { udbytte }\end{array}$} & \multirow{2}{*}{$\begin{array}{l}\text { Under- } \\
\text { visning } \\
\& \text { del- } \\
\text { tagelse }\end{array}$} & \multirow{2}{*}{$\begin{array}{l}\text { Problem- } \\
\text { er (fag } \\
\text { vs. sprog) }\end{array}$} & \multirow{2}{*}{$\begin{array}{l}\text { Sprog \& } \\
\text { identi- } \\
\text { tet }\end{array}$} & \multirow{2}{*}{$\begin{array}{l}\text { Sprog- } \\
\text { viden- } \\
\text { skab }\end{array}$} & \multicolumn{2}{|c|}{ Internationalisering } \\
\hline & $\begin{array}{l}\text { Stude- } \\
\text { rende }\end{array}$ & $\begin{array}{l}\text { Under- } \\
\text { viser }\end{array}$ & Andre & $\begin{array}{l}\text { Stude- } \\
\text { rende }\end{array}$ & $\begin{array}{l}\begin{array}{l}\text { Under } \\
\text {-viser }\end{array} \\
\end{array}$ & & & & & & $\begin{array}{l}\text { Sprog- } \\
\text { politik }\end{array}$ & $\begin{array}{l}\text { Studen- } \\
\text { termobi-litet }\end{array}$ \\
\hline $\begin{array}{l}\text { Lueg, K. \& Lueg, R. (2015). } \\
\text { English as a medium of } \\
\text { instruction at Sanish } \\
\text { universities: Status, } \\
\text { perspectives, and implications } \\
\text { for higher education executives. } \\
\text { Communication \& Language At } \\
\text { Work, 1(4), 53-73. }\end{array}$ & & & & & 1 & & & & & & 1 & \\
\hline $\begin{array}{l}\text { Madsen, M. (2008). Der vil altid } \\
\text { være brug for dansk. En } \\
\text { undersøgelse af } 11 \\
\text { naturvidenskabelige forskeres } \\
\text { grunde til at vælge henholdsvis } \\
\text { dansk og engelsk i deres } \\
\text { arbejde. (Købehavnerstudier i } \\
\text { tosprogethed, bind 48). } \\
\text { København: Københavns } \\
\text { Universitet, Det Humanistiske } \\
\text { Fakultet. }\end{array}$ & & 1 & 1 & & & & & & & & 1 & \\
\hline
\end{tabular}




\begin{tabular}{|c|c|c|c|c|c|c|c|c|c|c|c|c|}
\hline \multirow[t]{2}{*}{ Titel } & \multicolumn{3}{|c|}{ Holdninger } & \multicolumn{2}{|c|}{ Oplevelse } & \multirow{2}{*}{$\begin{array}{l}\text { Lærings- } \\
\text { udbytte }\end{array}$} & \multirow{2}{*}{$\begin{array}{l}\text { Under- } \\
\text { visning\& } \\
\text { del- } \\
\text { tagelse }\end{array}$} & \multirow{2}{*}{$\begin{array}{l}\text { Problem- } \\
\text { er (fag vs. } \\
\text { sprog) }\end{array}$} & \multirow{2}{*}{$\begin{array}{l}\text { Sprog\& } \\
\text { identi- } \\
\text { tet }\end{array}$} & \multirow{2}{*}{$\begin{array}{l}\text { Sprog- } \\
\text { viden- } \\
\text { skab }\end{array}$} & \multicolumn{2}{|c|}{ Internationalisering } \\
\hline & $\begin{array}{l}\text { Stude- } \\
\text { rende }\end{array}$ & $\begin{array}{l}\text { Under- } \\
\text { viser }\end{array}$ & Andre & $\begin{array}{l}\text { Stude- } \\
\text { rende }\end{array}$ & $\begin{array}{l}\text { Under- } \\
\text { viser }\end{array}$ & & & & & & $\begin{array}{l}\text { Sprog- } \\
\text { politik }\end{array}$ & $\begin{array}{l}\text { Studen- } \\
\text { termobilitet }\end{array}$ \\
\hline $\begin{array}{l}\text { Mortensen, J. \& Haberland, } \mathrm{H} \text {. } \\
\text { (2012). English - the new latin } \\
\text { of academia? Danish } \\
\text { universities as a case. } \\
\text { International Journal of the } \\
\text { Sociology of Language, 216, } \\
\text { 175-197. }\end{array}$ & & & & & & & & & & & 1 & \\
\hline $\begin{array}{l}\text { Mortensen, J. (2008). Circus } \\
\text { English? Investigating English } \\
\text { as an academic lingua franca at } \\
\text { BA study group meetings at } \\
\text { Roskilde University. I: H. } \\
\text { Haberland, J. Mortensen, A. } \\
\text { Fabricius,, B. Preisler, K. Risager } \\
\text { \& S. Kjærbeck (red.): Higher } \\
\text { Education in the Global Village: } \\
\text { Cultural and Linguistic Practices } \\
\text { in the International University. } \\
\text { Roskilde: Department of Culture } \\
\text { and Identity, Roskilde } \\
\text { Universitet, 85-96. }\end{array}$ & & & & & & & & & & 1 & & \\
\hline
\end{tabular}




\begin{tabular}{|c|c|c|c|c|c|c|c|c|c|c|c|c|}
\hline \multirow[t]{2}{*}{ Titel } & \multicolumn{3}{|c|}{ Holdninger } & \multicolumn{2}{|c|}{ Oplevelse } & \multirow{2}{*}{$\begin{array}{l}\text { Lærings- } \\
\text { udbytte }\end{array}$} & \multirow{2}{*}{$\begin{array}{l}\text { Under- } \\
\text { visning } \\
\& \text { del- } \\
\text { tagelse }\end{array}$} & \multirow{2}{*}{$\begin{array}{l}\text { Problem- } \\
\text { er (fag vs. } \\
\text { sprog) }\end{array}$} & \multirow{2}{*}{$\begin{array}{l}\text { Sprog \& } \\
\text { identi- } \\
\text { tet }\end{array}$} & \multirow{2}{*}{$\begin{array}{l}\text { Sprog- } \\
\text { viden- } \\
\text { skab }\end{array}$} & \multicolumn{2}{|c|}{ Internationalisering } \\
\hline & $\begin{array}{l}\text { Stude- } \\
\text { rende }\end{array}$ & $\begin{array}{l}\text { Under- } \\
\text { viser }\end{array}$ & Andre & $\begin{array}{l}\text { Stude- } \\
\text { rende }\end{array}$ & $\begin{array}{l}\text { Under } \\
\text {-viser }\end{array}$ & & & & & & $\begin{array}{l}\text { Sprog- } \\
\text { politik }\end{array}$ & \begin{tabular}{|l} 
Studen- \\
termobilitet
\end{tabular} \\
\hline $\begin{array}{l}\text { Nevile, M. \& Wagner, J. (2008). } \\
\text { Managing languages and } \\
\text { participation in a multilingual } \\
\text { group examination. I: H. } \\
\text { Haberland, J. Mortensen, A. } \\
\text { Fabricius, B. Preisler, K. Risager } \\
\text { \& S. Kjærbeck (red.): Higher } \\
\text { Education in the Global Village: } \\
\text { Cultural and Linguistic Practices } \\
\text { in the International University. } \\
\text { Roskilde: Department of Culture } \\
\text { and I dentity, Roskilde } \\
\text { Universitet, 149-175. }\end{array}$ & & & & & & & & 1 & & & & \\
\hline
\end{tabular}




\begin{tabular}{|c|c|c|c|c|c|c|c|c|c|c|c|c|}
\hline \multirow[t]{2}{*}{ Titel } & \multicolumn{3}{|c|}{ Holdninger } & \multicolumn{2}{|c|}{ Oplevelse } & \multirow{2}{*}{$\begin{array}{l}\text { Lærings- } \\
\text { udbytte }\end{array}$} & \multirow{2}{*}{$\begin{array}{l}\text { Under- } \\
\text { visning } \\
\& \text { del- } \\
\text { tagelse } \\
\end{array}$} & \multirow{2}{*}{$\begin{array}{l}\text { Problem- } \\
\text { er (fag vs. } \\
\text { sprog) }\end{array}$} & \multirow{2}{*}{$\begin{array}{l}\text { Sprog \& } \\
\text { identi- } \\
\text { tet }\end{array}$} & \multirow{2}{*}{$\begin{array}{l}\text { Sprog- } \\
\text { viden- } \\
\text { skab }\end{array}$} & \multicolumn{2}{|c|}{ Internationalisering } \\
\hline & $\begin{array}{l}\text { Stude- } \\
\text { rende }\end{array}$ & $\begin{array}{l}\text { Under- } \\
\text { viser }\end{array}$ & Andre & $\begin{array}{l}\text { Stude- } \\
\text { rende }\end{array}$ & $\begin{array}{l}\text { Under- } \\
\text { viser }\end{array}$ & & & & & & $\begin{array}{l}\text { Sprog- } \\
\text { politik }\end{array}$ & $\begin{array}{l}\text { Studen- } \\
\text { termobilitet }\end{array}$ \\
\hline $\begin{array}{l}\text { Odgaard, S. M. (2014). "Det er } \\
\text { ikke et sprog, man bare kan } \\
\text { samle op på gaden". En } \\
\text { undersøgelse af behovet for } \\
\text { kurser i akademisk dansk for } \\
\text { studerende med dansk som } \\
\text { andetsprog på Institut for } \\
\text { Tværkulturelle og Regionale } \\
\text { Studier på Københavns } \\
\text { Universitet. } \\
\text { (Københavnerstudier i } \\
\text { Tosprogethed: Studier i } \\
\text { Parallelsproglighed, bind C6). } \\
\text { København: Københavns } \\
\text { Universitet, Humanistisk } \\
\text { Fakultet. }\end{array}$ & & & & & & & & 1 & & & & \\
\hline
\end{tabular}




\begin{tabular}{|c|c|c|c|c|c|c|c|c|c|c|c|c|}
\hline \multirow[t]{2}{*}{ Titel } & \multicolumn{3}{|c|}{ Holdninger } & \multicolumn{2}{|c|}{ Oplevelse } & \multirow{2}{*}{$\begin{array}{l}\text { Lærings- } \\
\text { udbytte }\end{array}$} & \multirow{2}{*}{$\begin{array}{l}\text { Under- } \\
\text { visning } \\
\& \text { del- } \\
\text { tagelse }\end{array}$} & \multirow{2}{*}{$\begin{array}{l}\text { Problem- } \\
\text { er (fag vs. } \\
\text { sprog) }\end{array}$} & \multirow{2}{*}{$\begin{array}{l}\text { Sprog \& } \\
\text { identi- } \\
\text { tet }\end{array}$} & \multirow{2}{*}{$\begin{array}{l}\text { Sprog- } \\
\text { viden- } \\
\text { skab }\end{array}$} & \multicolumn{2}{|c|}{ Interna-tionalisering } \\
\hline & $\begin{array}{l}\text { Stude- } \\
\text { rende }\end{array}$ & $\begin{array}{l}\text { Under- } \\
\text { viser }\end{array}$ & Andre & \begin{tabular}{l|} 
Stude- \\
rende
\end{tabular} & $\begin{array}{l}\text { Under- } \\
\text { viser }\end{array}$ & & & & & & $\begin{array}{l}\text { Sprog- } \\
\text { politik }\end{array}$ & $\begin{array}{l}\text { Studen- } \\
\text { termobi-litet }\end{array}$ \\
\hline $\begin{array}{l}\text { Phillipson, R. \& T. Skutnabb- } \\
\text { Kangas (1999). "Englishisation: } \\
\text { One dimension of globalisation" } \\
\text { I: D. Graddol \& U. H. Meinhof } \\
\text { (red..): English in a Changing } \\
\text { World. Al LA Review 13, 19-36. } \\
\text { Guilford: Al LA. }\end{array}$ & & & & & & & & & & & 1 & \\
\hline $\begin{array}{l}\text { Preisler, B. (2005). } \\
\text { Deconstructing "the domain of } \\
\text { science" as a sociolinguistic } \\
\text { entity in EFL societies: the } \\
\text { relationship between English } \\
\text { and Danish in higher education } \\
\text { and research. I: B. Preisler, A. } \\
\text { Fabricius, H. Haberland, S. } \\
\text { Kjærbeck \& K. Risager (red.): } \\
\text { The Consequences of Mobility: } \\
\text { Linguistic and Sociocultural } \\
\text { Contact Zones, 238-248. } \\
\text { Roskilde: RUC, Institut for } \\
\text { Sprog og Kultur. }\end{array}$ & & & & & & & & & & & 1 & \\
\hline $\begin{array}{l}\text { Preisler, B. (2008): Teaching in } \\
\text { a foreign language: linguistic } \\
\text { performance and academic } \\
\text { authority in the international } \\
\text { university. I: H. Haberland, J. } \\
\text { Mortensen, A. Fabricius, B. } \\
\text { Preisler, K. Risager \& S. } \\
\text { Kjærbeck (red.): Higher } \\
\text { Education in the Global Village. } \\
\text { Roskilde: Department of Culture } \\
\text { and Identity, Roskilde University }\end{array}$ & & & & & & & & 1 & 1 & & & \\
\hline
\end{tabular}




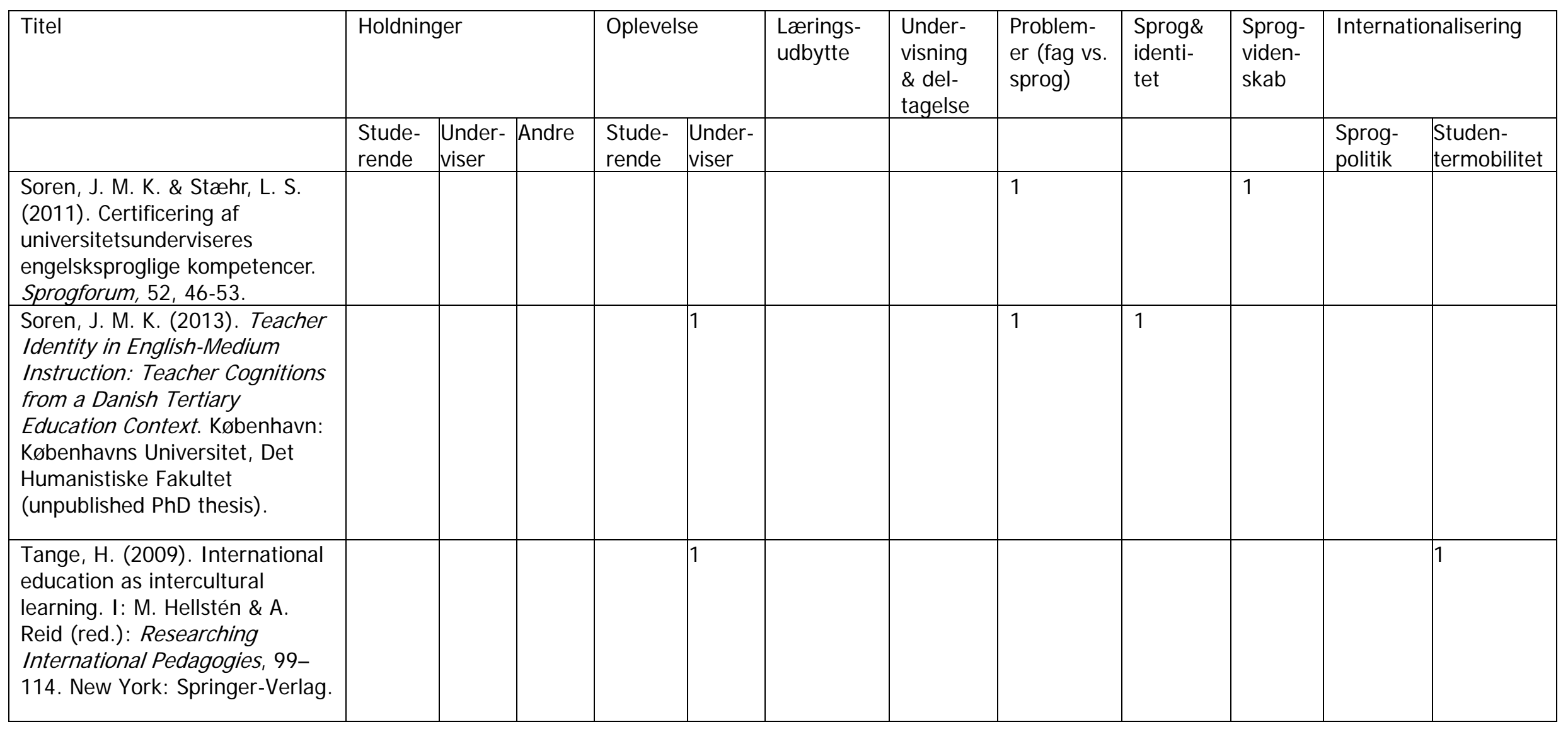




\begin{tabular}{|c|c|c|c|c|c|c|c|c|c|c|c|c|}
\hline \multirow[t]{2}{*}{ Titel } & \multicolumn{3}{|c|}{ Holdninger } & \multicolumn{2}{|c|}{ Oplevelse } & \multirow{2}{*}{$\begin{array}{l}\text { Lærings- } \\
\text { udbytte }\end{array}$} & \multirow{2}{*}{$\begin{array}{l}\text { Under- } \\
\text { visning } \\
\& \text { del- } \\
\text { tagelse }\end{array}$} & \multirow{2}{*}{$\begin{array}{l}\text { Problem- } \\
\text { er (fag vs. } \\
\text { sprog) }\end{array}$} & \multirow{2}{*}{$\begin{array}{l}\text { Sprog \& } \\
\text { identi- } \\
\text { tet }\end{array}$} & \multirow{2}{*}{$\begin{array}{l}\text { Sprog- } \\
\text { viden- } \\
\text { skab }\end{array}$} & \multicolumn{2}{|c|}{ Internationalisering } \\
\hline & $\begin{array}{l}\text { Stude- } \\
\text { rende }\end{array}$ & $\begin{array}{l}\text { Under- } \\
\text { viser }\end{array}$ & Andre & $\begin{array}{l}\text { Stude- } \\
\text { rende }\end{array}$ & $\begin{array}{l}\text { Under } \\
\text {-viser }\end{array}$ & & & & & & $\begin{array}{l}\text { Sprog- } \\
\text { politik }\end{array}$ & $\begin{array}{l}\text { Studen- } \\
\text { termobilitet }\end{array}$ \\
\hline $\begin{array}{l}\text { Tange, H. (2010). Underviser- } \\
\text { erfaringer med internationali- } \\
\text { sering. Aarhus: Aarhus School } \\
\text { of Business, University of } \\
\text { Aarhus, Department of } \\
\text { Language and Business } \\
\text { Communication. }\end{array}$ & & & & & 1 & & & & & & & \\
\hline $\begin{array}{l}\text { Tange, H. (2010). Caught in the } \\
\text { Tower of Babel: University } \\
\text { lecturers' experiences with } \\
\text { internationalization. Journal of } \\
\text { Language and International } \\
\text { Communication, 10, 137-49. }\end{array}$ & & & & & 1 & & 1 & 1 & & & & 1 \\
\hline $\begin{array}{l}\text { Thøgersen, J. (2013). Stylistic } \\
\text { and pedagogical consequences } \\
\text { of university teaching in English } \\
\text { in Europe. I: H. Haberland, D. } \\
\text { Lønsmann \& B. Preisler (red.), } \\
\text { Language Alternation, Language } \\
\text { Choice and Language Encounter } \\
\text { in International Tertiary } \\
\text { Education. Berlin: Springer. }\end{array}$ & & & & & & & 1 & & & & & \\
\hline
\end{tabular}




\begin{tabular}{|c|c|c|c|c|c|c|c|c|c|c|c|c|}
\hline Titel & Holdnir & ger & & Oplevel & & Lærings- & & & & & Interna & onalisering \\
\hline & $\begin{array}{l}\text { Stude- } \\
\text { rende }\end{array}$ & $\begin{array}{l}\text { Under- } \\
\text { viser }\end{array}$ & Andre & $\begin{array}{l}\text { Stude- } \\
\text { rende }\end{array}$ & $\begin{array}{l}\text { Under- } \\
\text { viser }\end{array}$ & & & & & & $\begin{array}{l}\text { Sprog- } \\
\text { politik }\end{array}$ & $\begin{array}{l}\text { Studen- } \\
\text { termobilitet }\end{array}$ \\
\hline $\begin{array}{l}\text { Thøgersen, J. \& Airey, J. } \\
\text { (2011). Teaching } \\
\text { undergraduate science in } \\
\text { Danish and in English: A } \\
\text { comparison of speaking rate } \\
\text { and rhetorical style. English for } \\
\text { Specific Purposes, 30, 209-221. }\end{array}$ & & & & & & 1 & & & & & & \\
\hline $\begin{array}{l}\text { Thøgersen, J., J osephsson, O., } \\
\text { Londen, M. \& Salö, L. (2014). } \\
\text { Engelsk som } \\
\text { undervisningssprog på nordiske } \\
\text { universiteter - hvordan gør } \\
\text { man? I F. Gregersen (red.): } \\
\text { Hvor parallelt?: Om } \\
\text { parallelspråkighet på Nordens } \\
\text { universitet. TemaNord 2014. } \\
\text { København: Nordisk } \\
\text { Ministerråd, 55-123. }\end{array}$ & & & & & & & 1 & & & & 1 & \\
\hline $\begin{array}{l}\text { Vinther, J. \& Slethaug, G. } \\
\text { (2015). The impact of } \\
\text { international students on the } \\
\text { university work environment: A } \\
\text { comparative study of a } \\
\text { Canadian and a Danish } \\
\text { university. Language and } \\
\text { Intercultural Communication, } \\
\text { 15(1), 92-108. }\end{array}$ & & & & & & & & 1 & & & & 1 \\
\hline
\end{tabular}




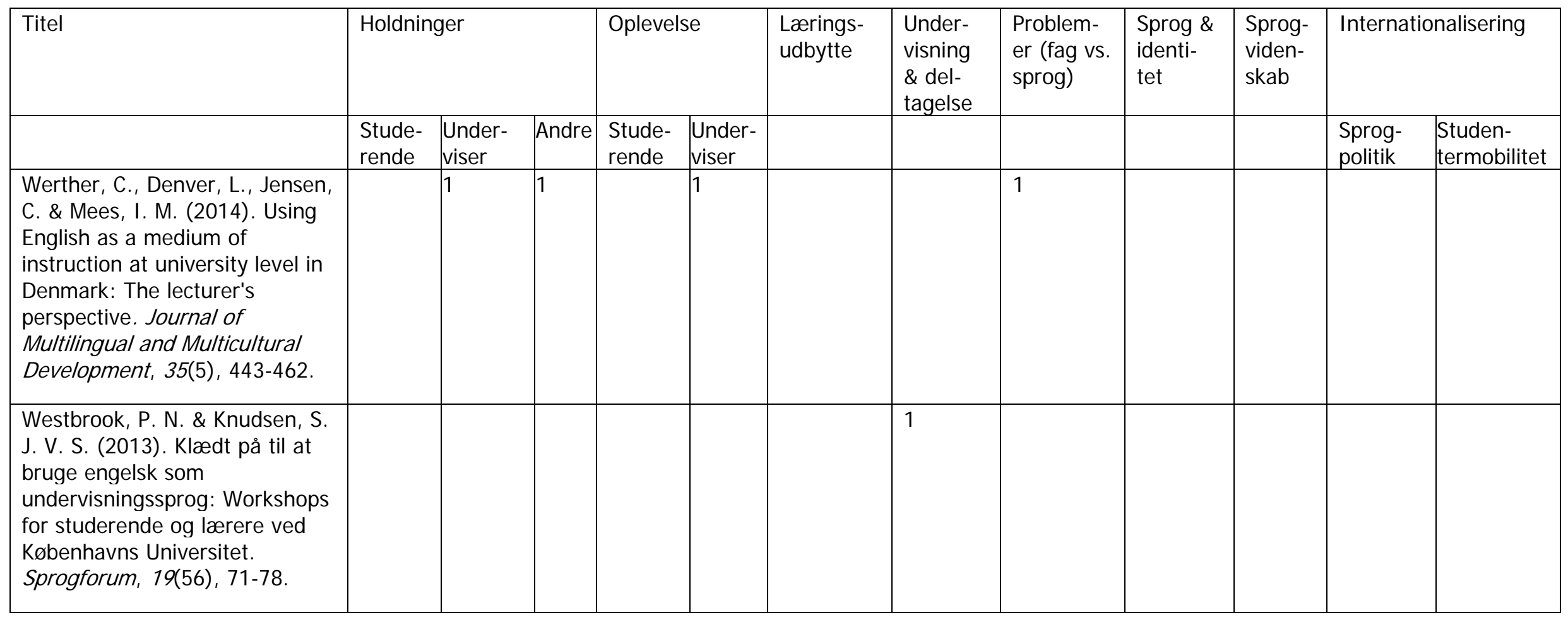




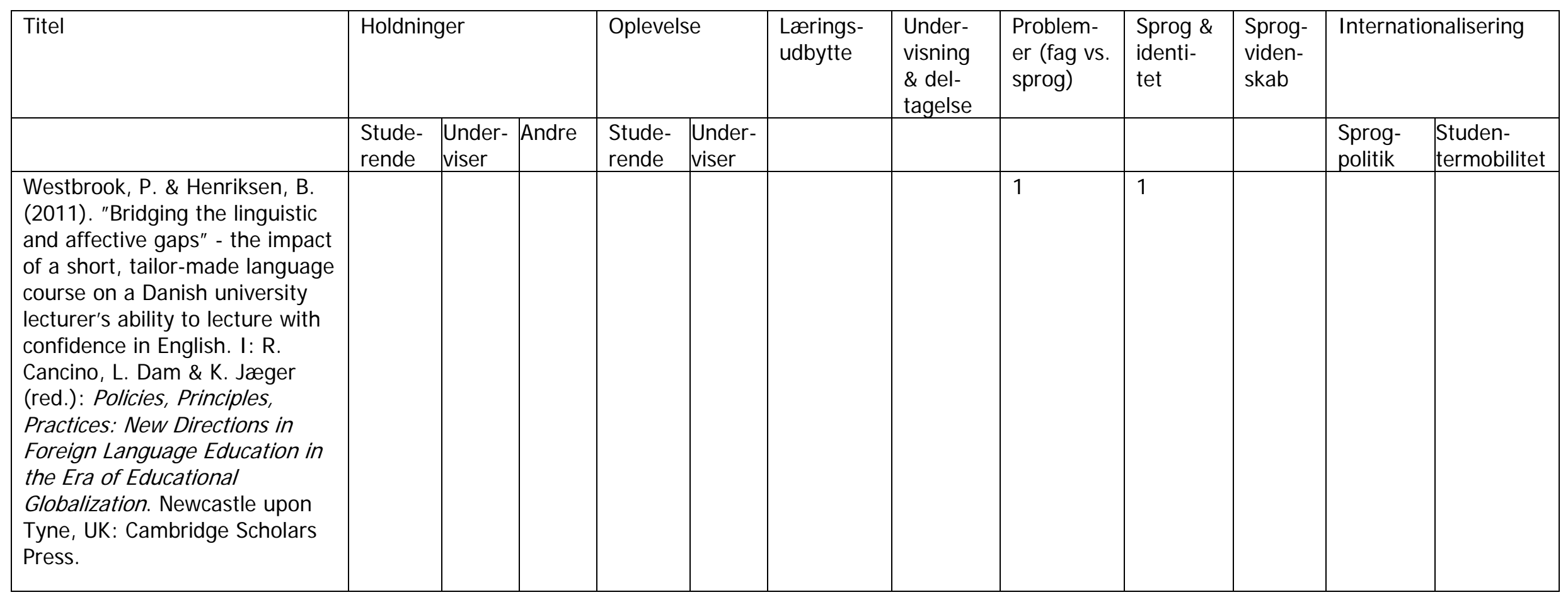


Appendix 2: Øvrig skandinavisk litteratur

\begin{tabular}{|c|c|c|c|c|c|c|c|c|c|c|c|c|}
\hline Titel & Holdnin & ger & & Oplevel & & Lærings- & Under- & Problem- & Sprog $\alpha$ & & Interna & tionalisering \\
\hline & $\begin{array}{l}\text { Stude- } \\
\text { rende }\end{array}$ & $\begin{array}{l}\text { Under- } \\
\text { viser }\end{array}$ & Andre & $\begin{array}{l}\text { Stude- } \\
\text { rende }\end{array}$ & $\begin{array}{l}\text { Under- } \\
\text { viser }\end{array}$ & & & & & & $\begin{array}{l}\text { Sprog- } \\
\text { politik }\end{array}$ & $\begin{array}{l}\text { Studen- } \\
\text { termobilitet }\end{array}$ \\
\hline $\begin{array}{l}\text { Airey, J. (2004). Can you teach } \\
\text { it in English? Aspects of the } \\
\text { language choice debate in } \\
\text { Swedish higher education. I: R. } \\
\text { Wilkinson (red.): Integrating } \\
\text { Content and Language: Meeting } \\
\text { the Challenge of a Multilingual } \\
\text { Higher Education, 97-108. } \\
\text { Maastricht, Netherlands: } \\
\text { Maastricht University Press. }\end{array}$ & & & & 1 & & & & & & & 1 & \\
\hline $\begin{array}{l}\text { Airey, J. (2009). Science, } \\
\text { Language and Literacy: Case } \\
\text { Studies of Learning in Swedish } \\
\text { University Physics. Uppsala, } \\
\text { Sweden: Acta Universitatis } \\
\text { Upsaliensis. (Unpublished PhD } \\
\text { thesis). }\end{array}$ & & & & & & 1 & & & & & & \\
\hline $\begin{array}{l}\text { Airey, J. (2010). "The ability of } \\
\text { students to explain science } \\
\text { concepts in two languages." } \\
\text { Hermes - Journal of Language } \\
\text { and Commmunication Studies, } \\
45,35-49 .\end{array}$ & & & & & & 1 & & 1 & & & & \\
\hline
\end{tabular}




\begin{tabular}{|c|c|c|c|c|c|c|c|c|c|c|c|c|}
\hline Titel & Holdnir & & & Oplevel & & Lærings- & Under- & & & Sprog- & Interna & tionalisering \\
\hline & $\begin{array}{l}\text { Stude- } \\
\text { rende }\end{array}$ & $\begin{array}{l}\text { Under- } \\
\text { viser }\end{array}$ & Andre & $\begin{array}{l}\text { Stude- } \\
\text { rende }\end{array}$ & $\begin{array}{l}\text { Under- } \\
\text { viser }\end{array}$ & & & & & & $\begin{array}{l}\text { Sprog- } \\
\text { politik }\end{array}$ & $\begin{array}{l}\text { Studentermo } \\
\text { bi-litet }\end{array}$ \\
\hline $\begin{array}{l}\text { Airey, J. (2011). The } \\
\text { relationship between teaching } \\
\text { language and student learning } \\
\text { in Swedish university physics. I: } \\
\text { B. Priesler, I. Klitgård \& A. H. } \\
\text { Fabricius (red.): Language and } \\
\text { Learning in the International } \\
\text { University: From English } \\
\text { Uniformity to Diversity and } \\
\text { Hybridity, 3-18. Bristol, UK: } \\
\text { Multilingual Matters. }\end{array}$ & & & & 1 & & & 1 & & & & & \\
\hline $\begin{array}{l}\text { Airey, J. (2011). Talking about } \\
\text { teaching in English: Swedish } \\
\text { university lecturers? } \\
\text { Experiences of changing } \\
\text { teaching language. Ibérica: } \\
\text { Revista de la Asociación } \\
\text { Europea de Lenguas para Fines } \\
\text { Específicos (AELFE), 22, 35-54. }\end{array}$ & & & & & 1 & & 1 & & & & & \\
\hline
\end{tabular}




\begin{tabular}{|c|c|c|c|c|c|c|c|c|c|c|c|c|}
\hline \multirow[t]{2}{*}{ Titel } & \multicolumn{3}{|c|}{ Holdninger } & \multicolumn{2}{|c|}{ Oplevelse } & \multirow{2}{*}{$\begin{array}{l}\text { Lærings- } \\
\text { udbytte }\end{array}$} & \multirow{2}{*}{$\begin{array}{l}\text { Under- } \\
\text { visning } \\
\& \text { del- } \\
\text { tagelse }\end{array}$} & \multirow{2}{*}{$\begin{array}{l}\text { Problemer } \\
\text { (fag vs. } \\
\text { sprog) }\end{array}$} & \multirow{2}{*}{$\begin{array}{l}\text { Sprog \& } \\
\text { identi- } \\
\text { tet }\end{array}$} & \multirow{2}{*}{$\begin{array}{l}\text { Sprog- } \\
\text { viden- } \\
\text { skab }\end{array}$} & \multicolumn{2}{|c|}{ Internationalisering } \\
\hline & $\begin{array}{l}\text { Stude- } \\
\text { rende }\end{array}$ & $\begin{array}{l}\text { Under- } \\
\text { viser }\end{array}$ & Andre & $\begin{array}{l}\text { Stude- } \\
\text { rende } \\
\end{array}$ & $\begin{array}{l}\text { Under- } \\
\text { viser }\end{array}$ & & & & & & $\begin{array}{l}\text { Sprog- } \\
\text { politik }\end{array}$ & $\begin{array}{l}\text { Studen- } \\
\text { termobilitet }\end{array}$ \\
\hline $\begin{array}{l}\text { Airey, J. (2012). "I Don't Teach } \\
\text { Language": The Linguistic } \\
\text { Attitudes of Physics Lecturers in } \\
\text { Sweden. AILA Review, 25, 64- } \\
79 .\end{array}$ & & & & & 1 & & & & & & & \\
\hline $\begin{array}{l}\text { Airey, J. \& Linder, C. (2007). } \\
\text { Disciplinary learning in a second } \\
\text { language: A case study from } \\
\text { university physics. I: R. } \\
\text { Wilkinson \& V. Zegers (red.): } \\
\text { Researching Content and } \\
\text { Language Integration in Higher } \\
\text { Education. Maastricht: } \\
\text { Maastricht University Language } \\
\text { Centre, 161-171. }\end{array}$ & & & & 1 & & & & & & & & \\
\hline
\end{tabular}




\begin{tabular}{|c|c|c|c|c|c|c|c|c|c|c|c|c|}
\hline \multirow[t]{2}{*}{ Titel } & \multicolumn{3}{|c|}{ Holdninger } & \multicolumn{2}{|c|}{ Oplevelse } & \multirow{2}{*}{$\begin{array}{l}\text { Lærings- } \\
\text { udbytte }\end{array}$} & \multirow{2}{*}{$\begin{array}{l}\text { Under- } \\
\text { visning } \\
\& \text { del- } \\
\text { tagelse }\end{array}$} & \multirow{2}{*}{$\begin{array}{l}\text { Problemer } \\
\text { (fag vs. } \\
\text { sprog) }\end{array}$} & \multirow{2}{*}{$\begin{array}{l}\text { Sprog \& } \\
\text { identi- } \\
\text { tet }\end{array}$} & \multirow{2}{*}{$\begin{array}{l}\text { Sprog- } \\
\text { viden- } \\
\text { skab }\end{array}$} & \multicolumn{2}{|c|}{ Internationalisering } \\
\hline & $\begin{array}{l}\text { Stude- } \\
\text { rende }\end{array}$ & $\begin{array}{l}\text { Under- } \\
\text { viser }\end{array}$ & Andre & $\begin{array}{l}\text { Stude- } \\
\text { rende }\end{array}$ & $\begin{array}{l}\text { Under- } \\
\text { viser }\end{array}$ & & & & & & $\begin{array}{l}\text { Sprog- } \\
\text { politik }\end{array}$ & \begin{tabular}{|l} 
Studen- \\
termobilitet
\end{tabular} \\
\hline $\begin{array}{l}\text { Airey, J. \& Linder, C. (2008). } \\
\text { Bilingual scientific literacy? The } \\
\text { use of English in Swedish } \\
\text { university science courses. } \\
\text { Nordic Journal of English } \\
\text { Studies, オЗ), 145-161. }\end{array}$ & & & & & & & 1 & & & & & \\
\hline $\begin{array}{l}\text { Björkman , B. (2008)."So where } \\
\text { we are": Spoken lingua franca } \\
\text { English at a Swedish technical } \\
\text { university. English Today, 24(2), } \\
\text { 11-17. }\end{array}$ & & & & & & & & & & 1 & & \\
\hline $\begin{array}{l}\text { Björkman, B. (2010). Spoken } \\
\text { lingua franca English at a } \\
\text { Swedish technical university: An } \\
\text { investigation of form and } \\
\text { communicative effectiveness. } \\
\text { Stockholm: Stockholm } \\
\text { University. (Unpublished PhD } \\
\text { thesis) }\end{array}$ & & & & & & & & 1 & & 1 & & \\
\hline $\begin{array}{l}\text { Björkman, B. (2010). So you } \\
\text { think you can ELF: English as a } \\
\text { lingua franca as the medium of } \\
\text { instruction. Hermes: Journal of } \\
\text { Language and Communication } \\
\text { Studies, 45, 77-96. }\end{array}$ & & & & & & & 1 & & & 1 & & \\
\hline
\end{tabular}




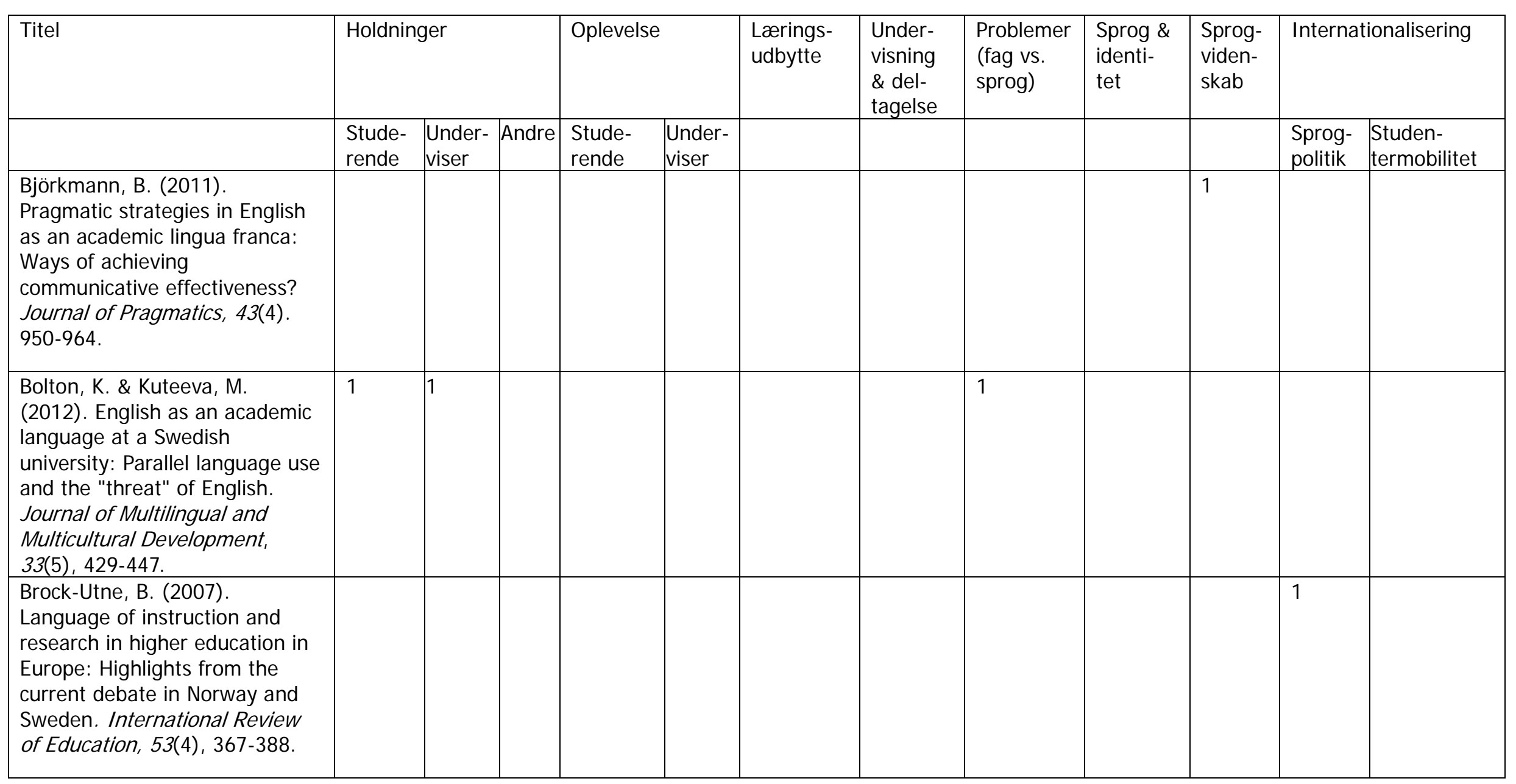




\begin{tabular}{|c|c|c|c|c|c|c|c|c|c|c|c|c|}
\hline Titel & Holdnin & & & Oplevel & & $\begin{array}{l}\text { Lærings- } \\
\text { udbytte }\end{array}$ & $\begin{array}{l}\text { Under- } \\
\text { visning }\end{array}$ & $\begin{array}{l}\text { Problemer } \\
\text { (fag vs. }\end{array}$ & $\begin{array}{l}\text { Sprog \& } \\
\text { identi- }\end{array}$ & $\begin{array}{l}\text { Sprog- } \\
\text { viden- }\end{array}$ & $\begin{array}{l}\text { Interna } \\
\text { tionalis }\end{array}$ & aring \\
\hline & $\begin{array}{l}\text { Stude- } \\
\text { rende }\end{array}$ & $\begin{array}{l}\text { Under- } \\
\text { viser }\end{array}$ & Andre & $\begin{array}{l}\text { Stude- } \\
\text { rende }\end{array}$ & $\begin{array}{l}\text { Under- } \\
\text { viser }\end{array}$ & & & & & & $\begin{array}{l}\text { Sprog- } \\
\text { politik }\end{array}$ & \begin{tabular}{|l|} 
Studen- \\
termobilitet
\end{tabular} \\
\hline $\begin{array}{l}\text { Gunnarsson, B.-L. \& Öhman, K. } \\
\text { (1997). Det internationaliserade } \\
\text { universitetet. En studie av } \\
\text { bruket av engelska och andra } \\
\text { främmande språk vid Uppsala } \\
\text { universitet. TeFa 16. Uppsala: } \\
\text { Uppsala Universitet, } \\
\text { Department of Scandinavian } \\
\text { Languages. }\end{array}$ & & & & & & & & & & & 1 & \\
\hline $\begin{array}{l}\text { Hellekjær, G. O. (2004). } \\
\text { Unprepared for English-medium } \\
\text { instruction: a critical look at } \\
\text { beginner students. I: R. } \\
\text { Wilkinson (red.): Integrating } \\
\text { Content and Language: Meeting } \\
\text { the Challenge of a Multilingual } \\
\text { Higher Education. Maastricht. } \\
\text { Universitaire pers Maastricht. }\end{array}$ & & & & & & & & 1 & & & & \\
\hline $\begin{array}{l}\text { Hellekjær, G. O. (2005): The } \\
\text { Acid Test: Does Upper } \\
\text { Secondary EFL Instruction } \\
\text { Effectively Prepare Norwegian } \\
\text { Students for the Reading of } \\
\text { English Textbooks at Colleges } \\
\text { and Universities? The University } \\
\text { of Oslo, The faculty of Arts, The } \\
\text { Department of Teacher } \\
\text { Education and School } \\
\text { Development. (Ph.d.- } \\
\text { afhandling). }\end{array}$ & & & & & & & & 1 & & & & \\
\hline
\end{tabular}


Academic English reading proficiency at the university level: A Norwegian case study. Reading in a Foreign Language, 21(2), 198-222.

\begin{tabular}{|c|c|c|c|c|c|c|c|c|c|c|c|c|}
\hline \multirow[t]{2}{*}{ Titel } & \multicolumn{3}{|c|}{ Holdninger } & \multicolumn{2}{|c|}{ Oplevelse } & \multirow{2}{*}{$\begin{array}{l}\text { Læ- } \\
\text { rings- } \\
\text { udbyt- } \\
\text { te }\end{array}$} & \multirow{2}{*}{$\begin{array}{l}\text { Under- } \\
\text { visning\& } \\
\text { del- } \\
\text { tagelse }\end{array}$} & \multirow{2}{*}{$\begin{array}{l}\text { Problemer } \\
\text { (fag vs. } \\
\text { sprog) }\end{array}$} & \multirow{2}{*}{$\begin{array}{l}\text { Sprog \& } \\
\text { identi- } \\
\text { tet }\end{array}$} & \multirow{2}{*}{$\begin{array}{l}\text { Sprog- } \\
\text { viden- } \\
\text { skab }\end{array}$} & \multicolumn{2}{|c|}{ Internationalisering } \\
\hline & $\begin{array}{l}\text { Stude- } \\
\text { rende }\end{array}$ & $\begin{array}{l}\text { Under- } \\
\text { viser }\end{array}$ & Andre & $\begin{array}{l}\text { Stude- } \\
\text { rende }\end{array}$ & $\begin{array}{l}\text { Under- } \\
\text { viser }\end{array}$ & & & & & & $\begin{array}{l}\text { Sprog- } \\
\text { politik }\end{array}$ & $\begin{array}{l}\text { Studen- } \\
\text { termobilitet }\end{array}$ \\
\hline $\begin{array}{l}\text { Hellekjær, G.O. (2010). } \\
\text { Language matters: Assessing } \\
\text { lecture comprehension in } \\
\text { Norwegian English-medium } \\
\text { higher education. I: C. Dalton- } \\
\text { Puffer, T. Nikula \& U. J. B. Smit } \\
\text { (red.): Language Use and } \\
\text { Language Learning in CLIL } \\
\text { Classrooms, 233-258. } \\
\text { Amsterdam: J ohn Benjamins. }\end{array}$ & & & & & & 1 & & 1 & & & & \\
\hline $\begin{array}{l}\text { Hellekjær, G. O. \& Westergaard, } \\
\text { M. R. (2002). An exploratory } \\
\text { survey of content learning } \\
\text { through English at Scandinavian } \\
\text { universities. I: A. M. Simensen } \\
\text { (red.): Teaching and Learning } \\
\text { Foreign Languages Issues and } \\
\text { Ideas, 47-61. Oslo: Unipub. }\end{array}$ & & & & & & & & 1 & & & & \\
\hline $\begin{array}{l}\text { Hincks, R. (2010): Speaking } \\
\text { rate and information content in } \\
\text { English lingua franca oral } \\
\text { presentations. English for } \\
\text { Specific Purposes, } 29(1), 4-18 \text {. }\end{array}$ & & & & & & & & 1 & & 1 & & \\
\hline
\end{tabular}




\begin{tabular}{|c|c|c|c|c|c|c|c|c|c|c|c|c|}
\hline \multirow[t]{2}{*}{ Titel } & \multicolumn{3}{|c|}{ Holdninger } & \multicolumn{2}{|c|}{ Oplevelse } & \multirow{2}{*}{$\begin{array}{l}\text { Lærings- } \\
\text { udbytte }\end{array}$} & \multirow{2}{*}{$\begin{array}{l}\text { Under- } \\
\text { visning } \\
\& \text { del- } \\
\text { tagelse }\end{array}$} & \multirow{2}{*}{$\begin{array}{l}\text { Problemer } \\
\text { (fag vs. } \\
\text { sprog) }\end{array}$} & \multirow{2}{*}{$\begin{array}{l}\text { Sprog \& } \\
\text { identi- } \\
\text { tet }\end{array}$} & \multirow{2}{*}{$\begin{array}{l}\text { Sprog- } \\
\text { viden- } \\
\text { skab }\end{array}$} & \multicolumn{2}{|c|}{ Internationalisering } \\
\hline & $\begin{array}{l}\text { Stude- } \\
\text { rende }\end{array}$ & $\begin{array}{l}\text { Under- } \\
\text { viser }\end{array}$ & Andre & $\begin{array}{l}\text { Stude- } \\
\text { rende }\end{array}$ & $\begin{array}{l}\text { Under- } \\
\text { viser }\end{array}$ & & & & & & $\begin{array}{l}\text { Sprog- } \\
\text { politik }\end{array}$ & \begin{tabular}{|l|} 
Studen- \\
termobilitet
\end{tabular} \\
\hline $\begin{array}{l}\text { Höglin, R. (2002). Engelska } \\
\text { språket som hot och tillgång i } \\
\text { Norden. Köpenhamn: Nordiska } \\
\text { Ministerrådet. }\end{array}$ & & & & & & & & & & & 1 & \\
\hline $\begin{array}{l}\text { Hyltenstam, K. (2004). } \\
\text { Engelskan, skolans } \\
\text { språkundervisning och svensk } \\
\text { språkpolitik. I: O. J osephson \& } \\
\text { B. Lindgren (red.): Engelskan i } \\
\text { Sverige. Språkval i utbildning, } \\
\text { arbete och kulturliv, 36-110. } \\
\text { Stockholm: Svenska } \\
\text { Språknämnden. }\end{array}$ & & & & & & & & & & & 1 & \\
\hline $\begin{array}{l}\text { Kuteeva, M. \& Airey, J. (2012). } \\
\text { Disciplinary differences in } \\
\text { knowledge structures and their } \\
\text { impact on the use of English in } \\
\text { Swedish higher education. } \\
\text { Higher Education, } 6 \pi 5), 533 \text { - } \\
549 .\end{array}$ & & & & & & & & & & & 1 & \\
\hline
\end{tabular}




\begin{tabular}{|c|c|c|c|c|c|c|c|c|c|c|c|c|}
\hline \multirow[t]{2}{*}{ Titel } & \multicolumn{3}{|c|}{ Holdninger } & \multicolumn{2}{|c|}{ Oplevelse } & \multirow{2}{*}{$\begin{array}{l}\text { Lærings- } \\
\text { udbytte }\end{array}$} & \multirow{2}{*}{$\begin{array}{l}\text { Under- } \\
\text { visning } \\
\& \text { del- } \\
\text { tagelse }\end{array}$} & \multirow{2}{*}{$\begin{array}{l}\text { Problemer } \\
\text { (fag vs. } \\
\text { sprog) }\end{array}$} & \multirow{2}{*}{$\begin{array}{l}\text { Sprog \& } \\
\text { identi- } \\
\text { tet }\end{array}$} & \multirow{2}{*}{$\begin{array}{l}\text { Sprog- } \\
\text { viden- } \\
\text { skab }\end{array}$} & \multicolumn{2}{|c|}{ Internationalisering } \\
\hline & $\begin{array}{l}\text { Stude- } \\
\text { rende }\end{array}$ & $\begin{array}{l}\text { Under- } \\
\text { viser }\end{array}$ & Andre & $\begin{array}{l}\text { Stude- } \\
\text { rende }\end{array}$ & $\begin{array}{l}\text { Under- } \\
\text { viser }\end{array}$ & & & & & & $\begin{array}{l}\text { Sprog- } \\
\text { politik }\end{array}$ & \begin{tabular}{|l|} 
Studen- \\
termobilitet
\end{tabular} \\
\hline $\begin{array}{l}\text { Kuteeva, M. (2014). The parallel } \\
\text { language use of Swedish and } \\
\text { English: The question of } \\
\text { "nativeness" in university } \\
\text { policies and practices. Journal } \\
\text { of Multilingual and Multicultural } \\
\text { Development, 35(4), 332-344. }\end{array}$ & 1 & & & & & & & & & & 1 & \\
\hline $\begin{array}{l}\text { Kuteeva, M. \& Airey, J. (2014). } \\
\text { Disciplinary differences in the } \\
\text { use of English in higher } \\
\text { education: Reflections on recent } \\
\text { Language policy developments. } \\
\text { Higher Education: The } \\
\text { International Journal of Higher } \\
\text { Education and Educational } \\
\text { Planning, 6オ5), 533-549. }\end{array}$ & & & & & & & & & & & 1 & \\
\hline
\end{tabular}




\begin{tabular}{|c|c|c|c|c|c|c|c|c|c|c|c|c|}
\hline \multirow[t]{2}{*}{ Titel } & \multicolumn{3}{|c|}{ Holdninger } & \multicolumn{2}{|c|}{ Oplevelse } & \multirow{2}{*}{$\begin{array}{l}\text { Lærings } \\
\text {-udbytte }\end{array}$} & \multirow{2}{*}{$\begin{array}{l}\text { Under- } \\
\text { visning } \\
\& \text { del- } \\
\text { tagelse }\end{array}$} & \multirow{2}{*}{$\begin{array}{l}\text { Problemer } \\
\text { (fag vs. } \\
\text { sprog) }\end{array}$} & \multirow{2}{*}{$\begin{array}{l}\text { Sprog \& } \\
\text { identi- } \\
\text { tet }\end{array}$} & \multirow{2}{*}{$\begin{array}{l}\text { Sprog- } \\
\text { viden- } \\
\text { skab }\end{array}$} & \multicolumn{2}{|c|}{ Internationalisering } \\
\hline & $\begin{array}{l}\text { Stude- } \\
\text { rende }\end{array}$ & $\begin{array}{l}\text { Under- } \\
\text { viser }\end{array}$ & Andre & $\begin{array}{l}\text { Stude- } \\
\text { rende }\end{array}$ & $\begin{array}{l}\text { Under- } \\
\text { viser }\end{array}$ & & & & & & $\begin{array}{l}\text { Sprog- } \\
\text { politik }\end{array}$ & $\begin{array}{l}\text { Studen- } \\
\text { termobilitet }\end{array}$ \\
\hline $\begin{array}{l}\text { Ljosland, R. (2008). Lingua } \\
\text { franca, prestisjespråk og } \\
\text { forestilt fellesskap: Om engelsk } \\
\text { som akademisk språk i Norge: } \\
\text { Et kasusstudium i bred } \\
\text { kontekst. Oslo: Norwegian } \\
\text { University of Science and } \\
\text { Technology. (PhD thesis). }\end{array}$ & 1 & 1 & 1 & 1 & 1 & & & & & 1 & 1 & \\
\hline $\begin{array}{l}\text { Ljosland, R. (2010). Teaching } \\
\text { through English: Monolingual } \\
\text { policy meets multilingual } \\
\text { practice. Hermes, 45, 99-113. }\end{array}$ & & & & & & & & & & 1 & 1 & \\
\hline
\end{tabular}




\begin{tabular}{|c|c|c|c|c|c|c|c|c|c|c|c|c|}
\hline \multirow[t]{2}{*}{ Titel } & \multicolumn{3}{|c|}{ Holdninger } & \multicolumn{2}{|c|}{ Oplevelse } & \multirow{2}{*}{$\begin{array}{l}\text { Lærings- } \\
\text { udbytte }\end{array}$} & \multirow{2}{*}{$\begin{array}{l}\text { Under- } \\
\text { visning } \\
\& \text { del- } \\
\text { tagelse }\end{array}$} & \multirow{2}{*}{$\begin{array}{l}\text { Problemer } \\
\text { (fag vs. } \\
\text { sprog) }\end{array}$} & \multirow{2}{*}{$\begin{array}{l}\text { Sprog \& } \\
\text { identi- } \\
\text { tet }\end{array}$} & \multirow{2}{*}{$\begin{array}{l}\text { Sprog- } \\
\text { viden- } \\
\text { skab }\end{array}$} & \multicolumn{2}{|c|}{ Internationalisering } \\
\hline & $\begin{array}{l}\text { Stude- } \\
\text { rende }\end{array}$ & $\begin{array}{l}\text { Under- } \\
\text { viser }\end{array}$ & Andre & $\begin{array}{l}\text { Stude- } \\
\text { rende }\end{array}$ & $\begin{array}{l}\text { Under- } \\
\text { viser }\end{array}$ & & & & & & $\begin{array}{l}\text { Sprog- } \\
\text { politik }\end{array}$ & \begin{tabular}{|l} 
Studen- \\
termobilitet
\end{tabular} \\
\hline $\begin{array}{l}\text { Ljosland, R. (2014). Language } \\
\text { planning confronted by } \\
\text { everyday communication in the } \\
\text { international university: The } \\
\text { Norwegian case. Journal of } \\
\text { Multilingual and Multicultural } \\
\text { Development, 35(4), 392-405. }\end{array}$ & & & & & & & & & & 1 & 1 & \\
\hline $\begin{array}{l}\text { Nilsson, B. (2003). } \\
\text { Internationalization at home } \\
\text { from a Swedish perspective: } \\
\text { The case of Malmö. Journal of } \\
\text { Studies in International } \\
\text { education, } \pi 1), 27-40 \text {. }\end{array}$ & & & & & & & & & & & 1 & \\
\hline
\end{tabular}




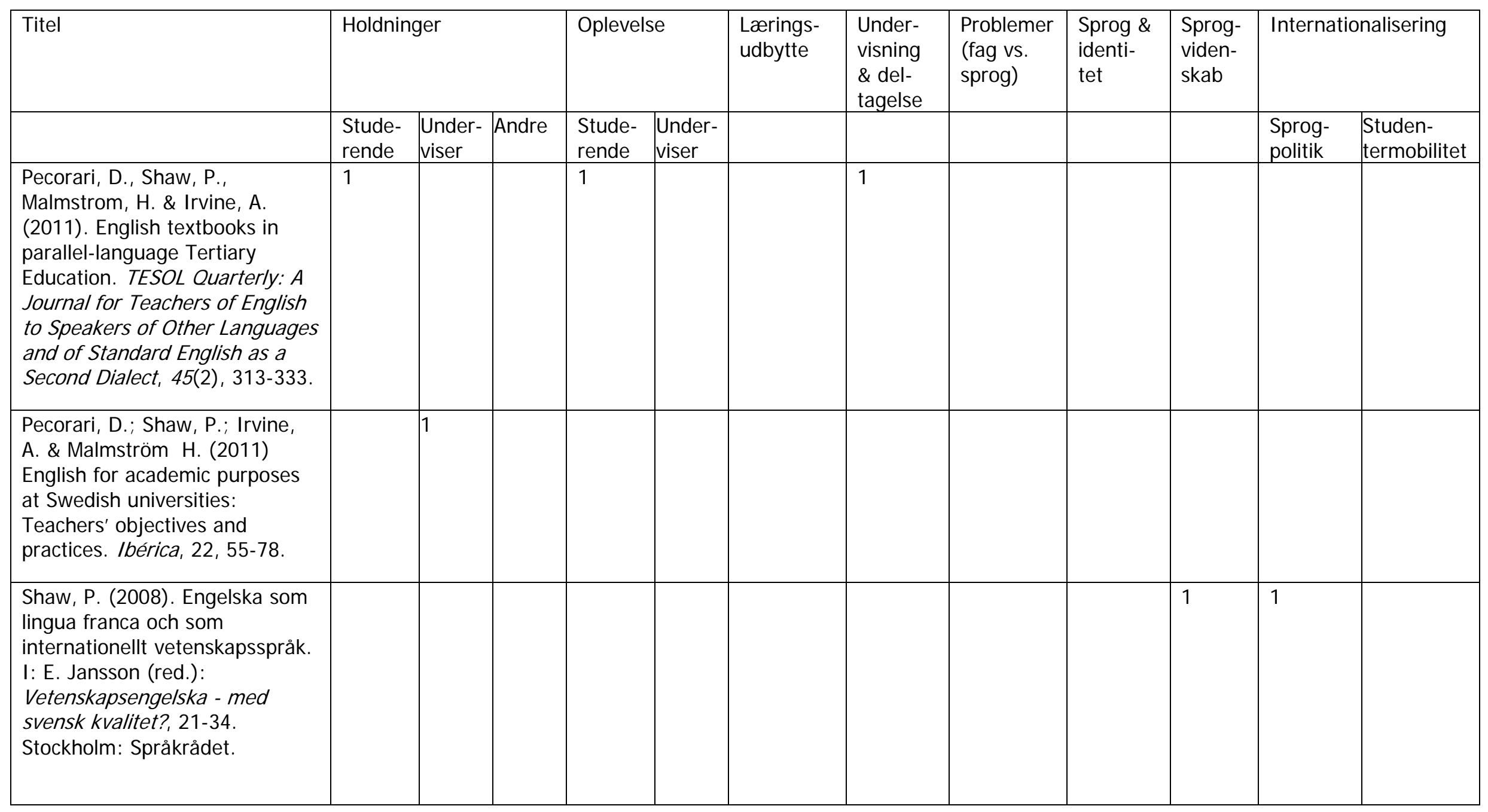




\begin{tabular}{|c|c|c|c|c|c|c|c|c|c|c|c|c|}
\hline \multirow[t]{2}{*}{ Titel } & \multicolumn{3}{|c|}{ Holdninger } & \multicolumn{2}{|c|}{ Oplevelse } & \multirow{2}{*}{$\begin{array}{l}\text { Lærings } \\
\text {-udbytte }\end{array}$} & \multirow{2}{*}{$\begin{array}{l}\text { Under- } \\
\text { visning } \\
\& \text { del- } \\
\text { tagelse }\end{array}$} & \multirow{2}{*}{$\begin{array}{l}\text { Problemer } \\
\text { (fag vs. } \\
\text { sprog) }\end{array}$} & \multirow{2}{*}{$\begin{array}{l}\text { Sprog \& } \\
\text { identi- } \\
\text { tet }\end{array}$} & \multirow{2}{*}{$\begin{array}{l}\text { Sprog- } \\
\text { viden- } \\
\text { skab }\end{array}$} & \multicolumn{2}{|c|}{ Internationalisering } \\
\hline & $\begin{array}{l}\text { Stude- } \\
\text { rende }\end{array}$ & $\begin{array}{l}\text { Under- } \\
\text { viser }\end{array}$ & Andre & $\begin{array}{l}\text { Stude- } \\
\text { rende }\end{array}$ & $\begin{array}{l}\text { Under- } \\
\text { viser }\end{array}$ & & & & & & $\begin{array}{l}\text { Sprog- } \\
\text { politik }\end{array}$ & $\begin{array}{l}\text { Studenter- } \\
\text { mobilitet }\end{array}$ \\
\hline $\begin{array}{l}\text { Söderlundh, H. (2010). } \\
\text { Internationella universitet - } \\
\text { lokala spräkval. Om bruket av } \\
\text { talad svenska i engelsksprakiga } \\
\text { kursmiljöer. Uppsala: Uppsala } \\
\text { Universitet. }\end{array}$ & 1 & 1 & & & & & & & & 1 & & \\
\hline $\begin{array}{l}\text { Söderlundh, H. (2012). Global } \\
\text { policies and local norms: } \\
\text { Sociolinguistic awareness and } \\
\text { language choice at an } \\
\text { international university. } \\
\text { International Journal of the } \\
\text { Sociology of Language, 216, 87- } \\
\text { 109. }\end{array}$ & & & & & & & & & & & 1 & \\
\hline
\end{tabular}




\begin{tabular}{|c|c|c|c|c|c|c|c|c|c|c|c|c|}
\hline \multirow[t]{2}{*}{ Titel } & \multicolumn{3}{|c|}{ Holdninger } & \multicolumn{2}{|c|}{ Oplevelse } & \multirow{2}{*}{$\begin{array}{l}\text { Lærings } \\
\text {-udbytte }\end{array}$} & \multirow{2}{*}{$\begin{array}{l}\text { Under- } \\
\text { visning } \\
\& \text { del- } \\
\text { tagelse } \\
\end{array}$} & \multirow{2}{*}{$\begin{array}{l}\text { Problemer } \\
\text { (fag vs. } \\
\text { sprog) }\end{array}$} & \multirow{2}{*}{$\begin{array}{l}\text { Sprog \& } \\
\text { identi- } \\
\text { tet }\end{array}$} & \multirow{2}{*}{$\begin{array}{l}\text { Sprog- } \\
\text { viden- } \\
\text { skab }\end{array}$} & \multicolumn{2}{|c|}{ Internationalisering } \\
\hline & $\begin{array}{l}\text { Stude- } \\
\text { rende }\end{array}$ & $\begin{array}{l}\text { Under- } \\
\text { viser }\end{array}$ & Andre & $\begin{array}{l}\text { Stude- } \\
\text { rende }\end{array}$ & $\begin{array}{l}\text { Under- } \\
\text { viser }\end{array}$ & & & & & & $\begin{array}{l}\text { Sprog- } \\
\text { politik }\end{array}$ & $\begin{array}{l}\text { Studen- } \\
\text { termobilitet }\end{array}$ \\
\hline $\begin{array}{l}\text { Söderlundh, H. (2008). } \\
\text { Language practices in Swedish } \\
\text { higher education: Results from } \\
\text { a pilot study. I: H. Haberland, J. } \\
\text { Mortensen, A. Fabricius, B. } \\
\text { Preisler, K. Risager \& S. } \\
\text { Kjærbeck (red.): Higher } \\
\text { Education in the Global Village, } \\
\text { 97-102. Roskilde: Roskilde } \\
\text { University, Department of } \\
\text { Culture and Identity. }\end{array}$ & & & & & & & & & & 1 & & \\
\hline $\begin{array}{l}\text { Östman, L. (1998). How } \\
\text { companion meanings are } \\
\text { expressed by science education } \\
\text { discourse. I: D. Roberts \& L. } \\
\text { Östman (red.): Problems of } \\
\text { Meaning in Science Education, } \\
\text { 54-70. New York: Teachers } \\
\text { College Press. }\end{array}$ & & & & & & & & & & & & \\
\hline
\end{tabular}




\section{Appendix 3: I nternational litteratur}

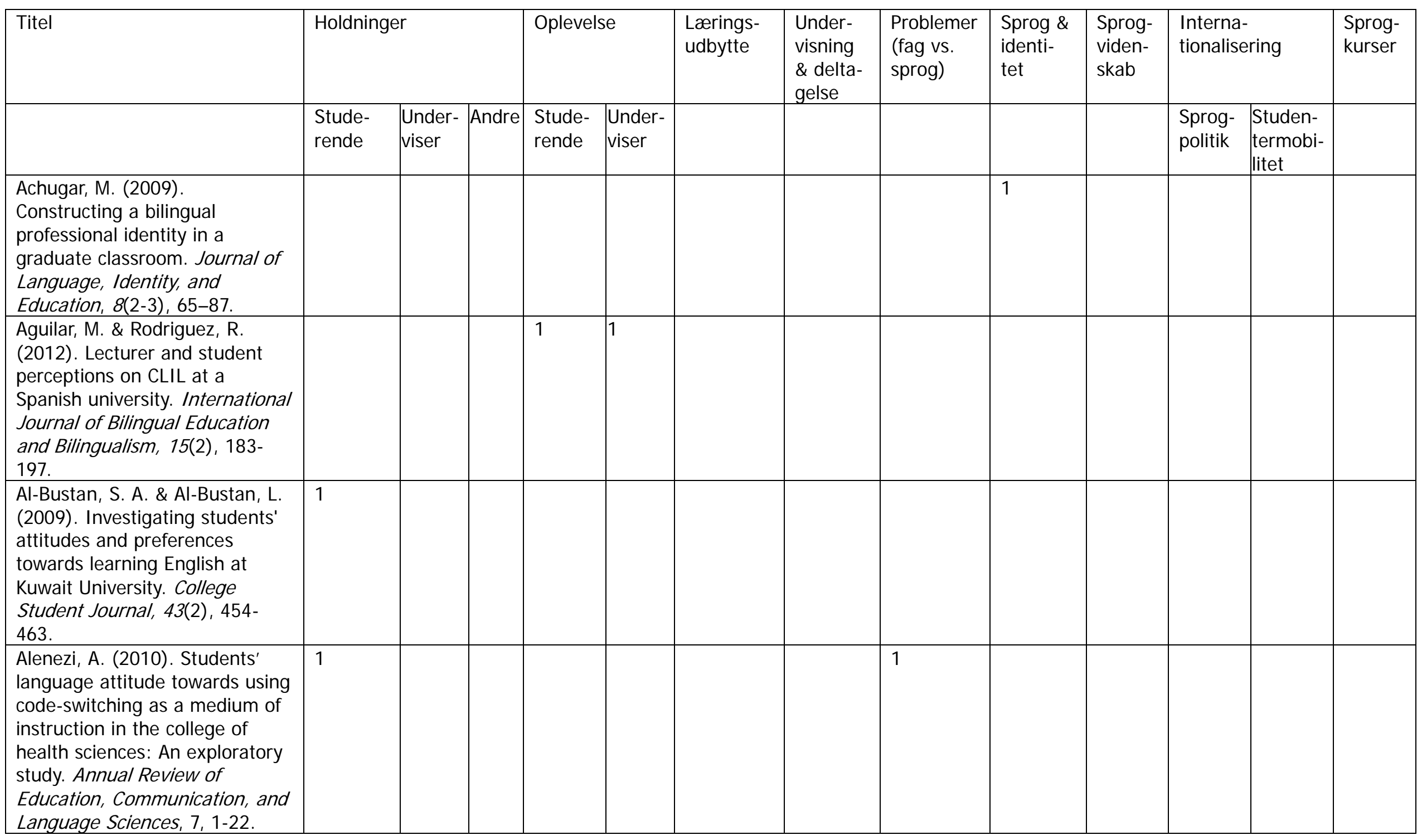




\begin{tabular}{|c|c|c|c|c|c|c|c|c|c|c|c|c|c|}
\hline \multirow[t]{2}{*}{ Titel } & \multicolumn{3}{|c|}{ Holdninger } & \multicolumn{2}{|c|}{ Oplevelse } & \multirow[t]{2}{*}{$\begin{array}{l}\text { Lærings- } \\
\text { udbytte }\end{array}$} & \multirow{2}{*}{$\begin{array}{l}\text { Under- } \\
\text { visning } \\
\& \text { delta- } \\
\text { gelse }\end{array}$} & \multirow{2}{*}{$\begin{array}{l}\text { Problem- } \\
\text { er (fag vs. } \\
\text { sprog) }\end{array}$} & \multirow{2}{*}{$\begin{array}{l}\text { Sprog\& } \\
\text { identi- } \\
\text { tet }\end{array}$} & \multirow{2}{*}{$\begin{array}{l}\text { Sprog- } \\
\text { viden- } \\
\text { skab }\end{array}$} & \multicolumn{2}{|c|}{$\begin{array}{l}\text { Interna- } \\
\text { tionalisering }\end{array}$} & \multirow[t]{2}{*}{$\begin{array}{l}\text { Sprog- } \\
\text { kurser }\end{array}$} \\
\hline & $\begin{array}{l}\text { Stude- } \\
\text { rende }\end{array}$ & $\begin{array}{l}\text { Under- } \\
\text { viser }\end{array}$ & Andre & $\begin{array}{l}\text { Stude- } \\
\text { rende }\end{array}$ & $\begin{array}{l}\text { Under- } \\
\text { viser }\end{array}$ & & & & & & $\begin{array}{l}\text { Sprog- } \\
\text { politik }\end{array}$ & $\begin{array}{l}\text { Studen- } \\
\text { termobi- } \\
\text { litet }\end{array}$ & \\
\hline $\begin{array}{l}\text { Altbach, P. G. \& Knight, J. } \\
\text { (2007). The internationalization } \\
\text { of higher education: Motivations } \\
\text { and realities. Journal of Studies } \\
\text { in International Education, } \\
\text { 11(3-4), 290-305. }\end{array}$ & & & & & & & & & & & 1 & & \\
\hline $\begin{array}{l}\text { Andersson, I. \& Rusanganwa, J. } \\
\text { (2011). Language and space in } \\
\text { a multilingual undergraduate } \\
\text { physics classroom in Rwanda. } \\
\text { International Journal of Bilingual } \\
\text { Education and Bilingualism, } \\
\text { 14(6).751-764. }\end{array}$ & & & & & & & & 1 & 1 & 1 & & & \\
\hline $\begin{array}{l}\text { Andrade, M. S. (2007). } \\
\text { Addressing the linguistic needs } \\
\text { of nonnative English speakers in } \\
\text { the first year. Journal of The } \\
\text { First-Year Experience \& } \\
\text { Students in Transition, 192), } \\
\text { 69-86. }\end{array}$ & & & & & & & & 1 & & & & & 1 \\
\hline
\end{tabular}




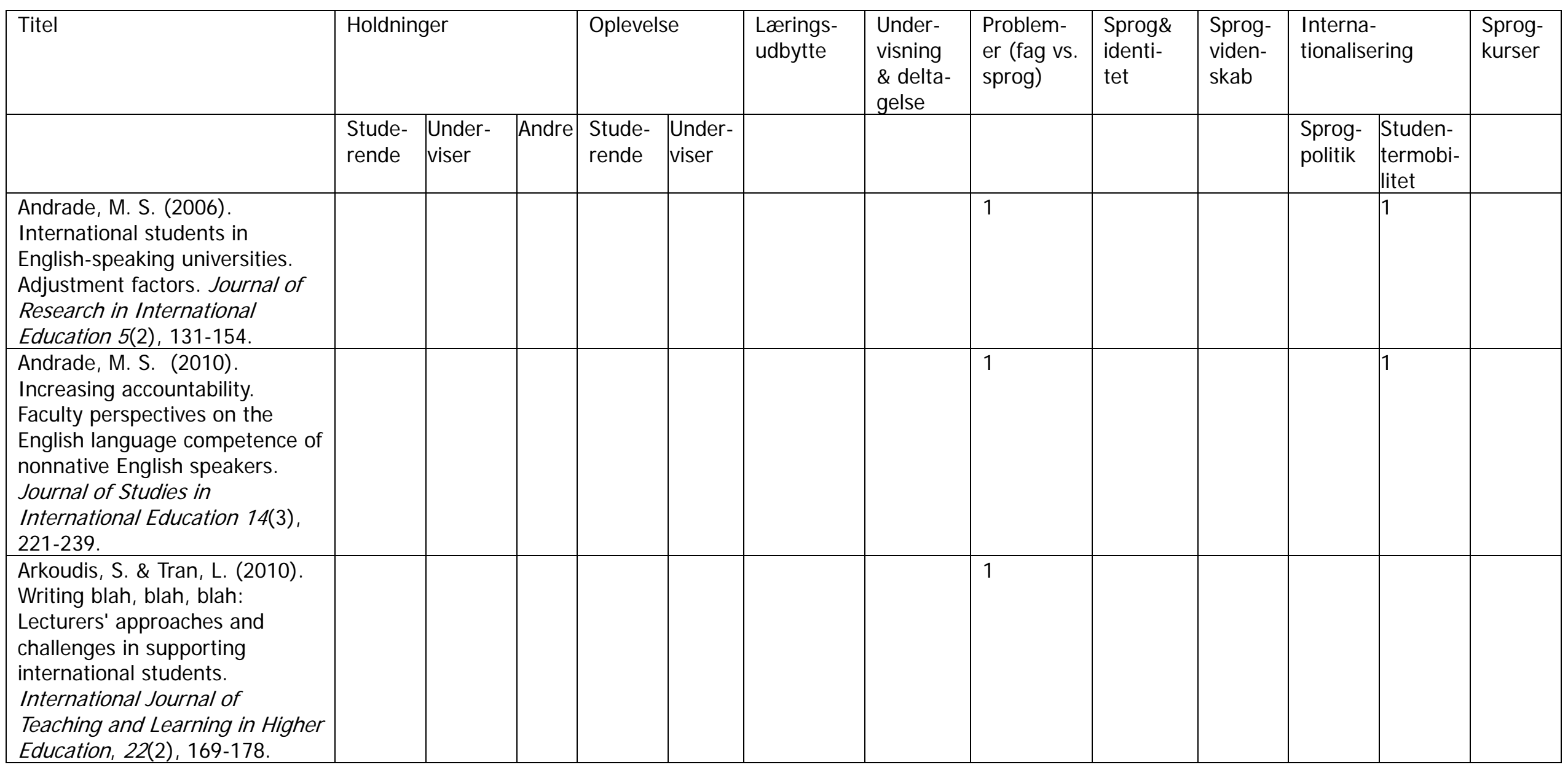




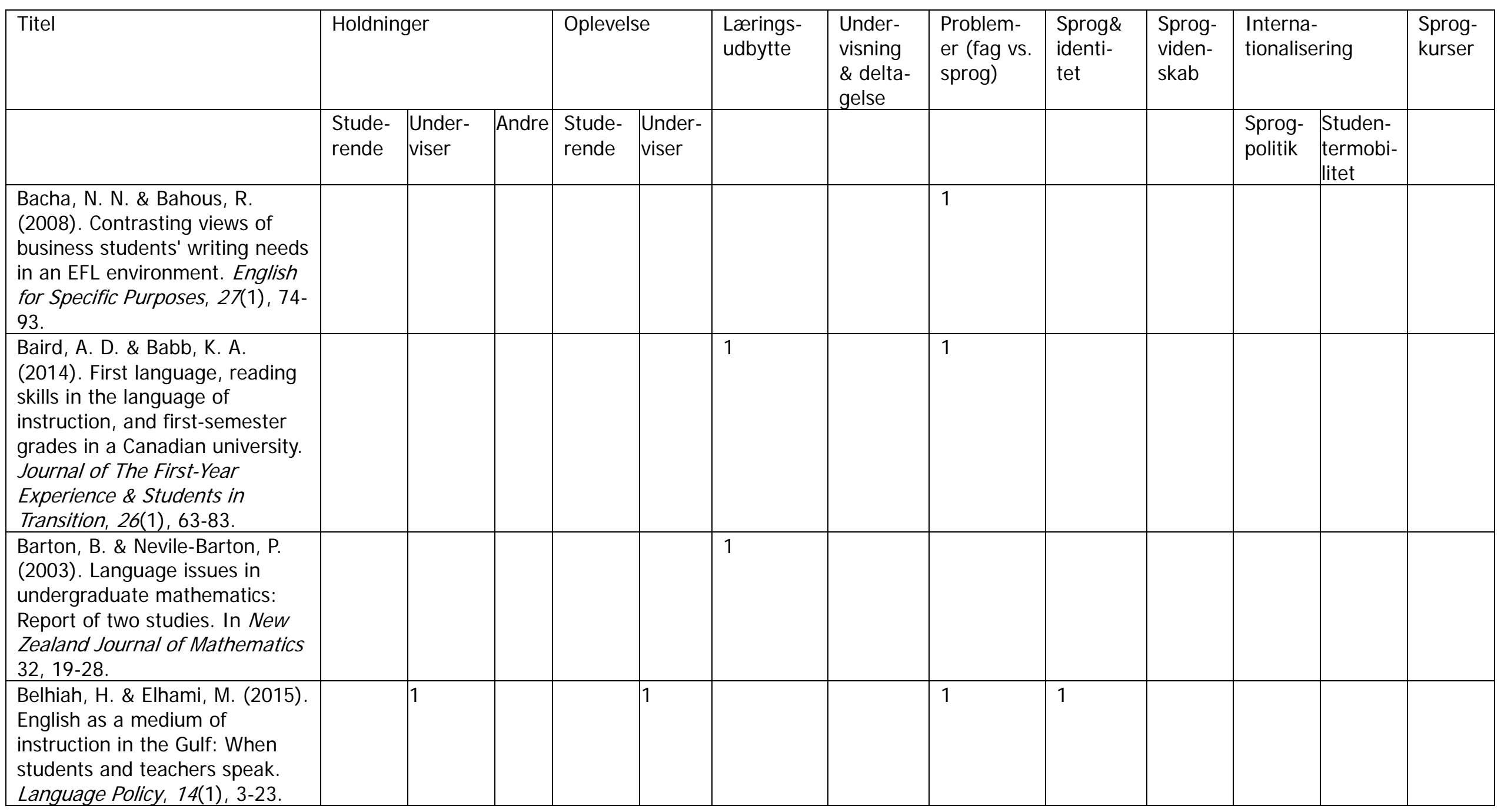




\begin{tabular}{|c|c|c|c|c|c|c|c|c|c|c|c|c|c|}
\hline Titel & Holdnin & ger & & Opleve & & $\begin{array}{l}\text { Lærings- } \\
\text { udbytte }\end{array}$ & $\begin{array}{l}\text { Under- } \\
\text { visning }\end{array}$ & $\begin{array}{l}\text { Problem- } \\
\text { er (fag vs. }\end{array}$ & $\begin{array}{l}\text { Sprog\& } \\
\text { identi- }\end{array}$ & $\begin{array}{l}\text { Sprog- } \\
\text { viden- }\end{array}$ & $\begin{array}{l}\text { Interna } \\
\text { tionalis }\end{array}$ & ering & $\begin{array}{l}\text { Sprog- } \\
\text { kurser }\end{array}$ \\
\hline & $\begin{array}{l}\text { Stude- } \\
\text { rende }\end{array}$ & $\begin{array}{l}\text { Under- } \\
\text { viser }\end{array}$ & Andre & $\begin{array}{l}\text { Stude- } \\
\text { rende }\end{array}$ & $\begin{array}{l}\text { Under- } \\
\text { viser }\end{array}$ & & & & & & $\begin{array}{l}\text { Sprog- } \\
\text { politik }\end{array}$ & $\begin{array}{l}\text { Studen- } \\
\text { termobi- } \\
\text { litet }\end{array}$ & \\
\hline $\begin{array}{l}\text { Bennett, R. J., Volet, S. E. \& } \\
\text { Fozdar, F. E. (2013). "I 'd say it's } \\
\text { kind of unique in a way": The } \\
\text { development of an intercultural } \\
\text { student relationship. Journal of } \\
\text { Studies in International } \\
\text { Education, } 1 \pi 5 \text { ), 533-553. }\end{array}$ & & & & & & & & & & & & 1 & \\
\hline $\begin{array}{l}\text { Benzie, H. J. (2010). Graduating } \\
\text { as a "native speaker": } \\
\text { International students and } \\
\text { English language proficiency in } \\
\text { higher education. Higher } \\
\text { Education Research and } \\
\text { Development, 2944), 447-459. }\end{array}$ & & 1 & & & & & & 1 & & & & 1 & \\
\hline $\begin{array}{l}\text { Bifuh-Ambe, E. (2011). } \\
\text { Postsecondary learning: } \\
\text { Recognizing the needs of } \\
\text { English language learners in } \\
\text { mainstream university } \\
\text { classrooms. Multicultural } \\
\text { Education, 19(3), 13-19. }\end{array}$ & & & & & & & & 1 & & & & & \\
\hline
\end{tabular}




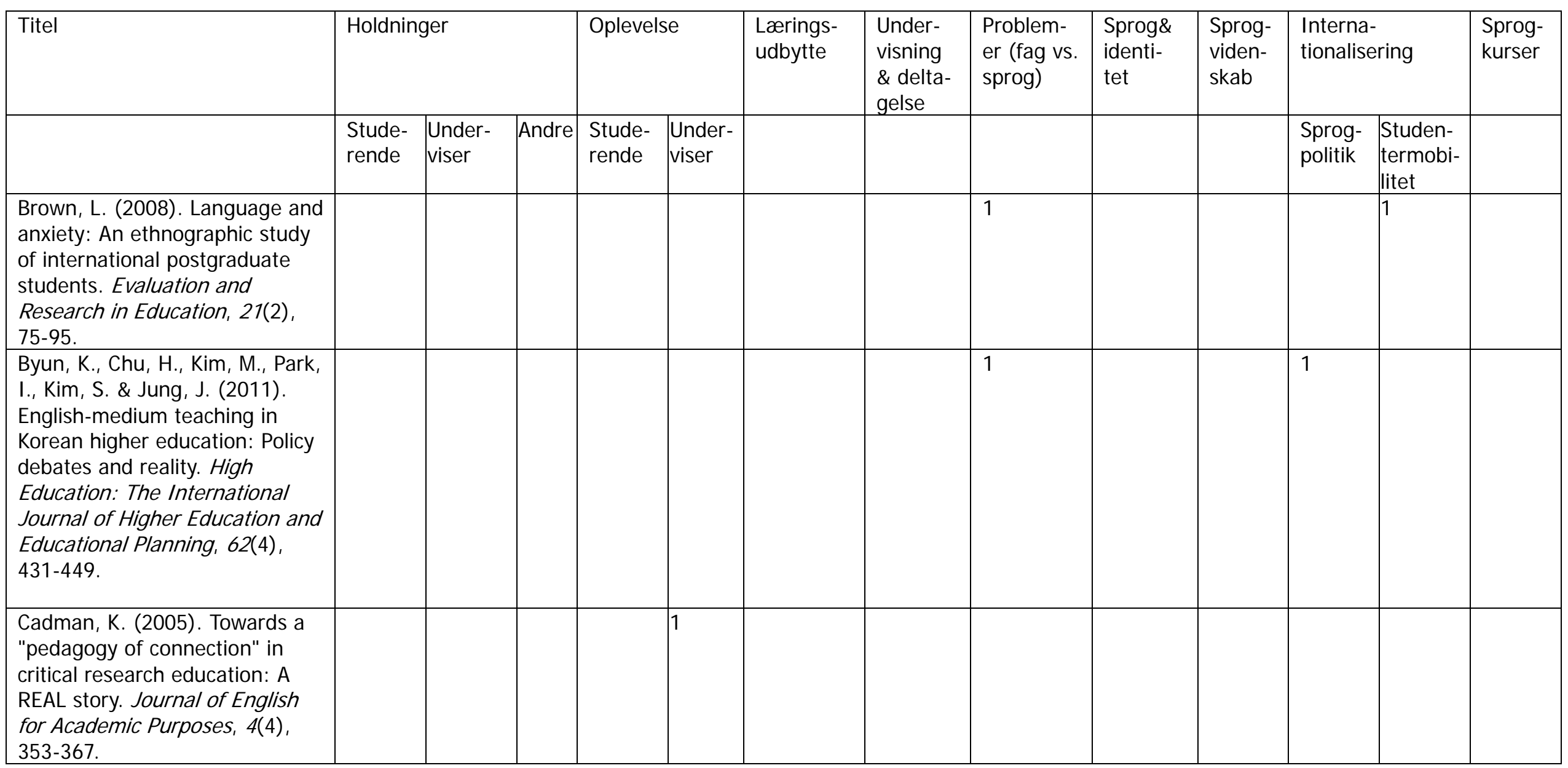




\begin{tabular}{|c|c|c|c|c|c|c|c|c|c|c|c|c|c|}
\hline \multirow[t]{2}{*}{ Titel } & \multicolumn{3}{|c|}{ Holdninger } & \multicolumn{2}{|c|}{ Oplevelse } & \multirow[t]{2}{*}{$\begin{array}{l}\text { Lærings- } \\
\text { udbytte }\end{array}$} & \multirow{2}{*}{$\begin{array}{l}\text { Under- } \\
\text { visning } \\
\& \text { delta- } \\
\text { gelse }\end{array}$} & \multirow{2}{*}{$\begin{array}{l}\text { Problem- } \\
\text { er (fag vs. } \\
\text { sprog) }\end{array}$} & \multirow{2}{*}{$\begin{array}{l}\text { Sprog\& } \\
\text { identi- } \\
\text { tet }\end{array}$} & \multirow{2}{*}{$\begin{array}{l}\text { Sprog- } \\
\text { viden- } \\
\text { skab }\end{array}$} & \multicolumn{2}{|c|}{$\begin{array}{l}\text { Interna- } \\
\text { tionalisering }\end{array}$} & \multirow[t]{2}{*}{$\begin{array}{l}\text { Sprog- } \\
\text { kurser }\end{array}$} \\
\hline & $\begin{array}{l}\text { Stude- } \\
\text { rende }\end{array}$ & $\begin{array}{l}\text { Under- } \\
\text { viser }\end{array}$ & Andre & $\begin{array}{l}\text { Stud } \\
\text { e- } \\
\text { rend } \\
\text { e }\end{array}$ & $\begin{array}{l}\text { Under- } \\
\text { viser }\end{array}$ & & & & & & $\begin{array}{l}\text { Sprog- } \\
\text { politik }\end{array}$ & $\begin{array}{l}\text { Studen- } \\
\text { termobi- } \\
\text { litet }\end{array}$ & \\
\hline $\begin{array}{l}\text { Canagarajah, A. S. (2010). } \\
\text { Challenges in English literacy for } \\
\text { African-American and Lankan } \\
\text { Tamil learners: Towards a } \\
\text { pedagogical paradigm for } \\
\text { bidialectal and bilingual minority } \\
\text { students. Language and } \\
\text { Education, 11(1), 15-37. }\end{array}$ & & & & & & & & & 1 & & & & \\
\hline $\begin{array}{l}\text { Camiciottoli, B. C. (2010). } \\
\text { Meeting the challenges of } \\
\text { European student mobility: } \\
\text { Preparing Italian Erasmus } \\
\text { students for business lectures in } \\
\text { English. English for Specific } \\
\text { Purposes, 294), 268-280. }\end{array}$ & & & & 1 & & & & 1 & & & & 1 & \\
\hline $\begin{array}{l}\text { Cavazos, A. G. (2015). } \\
\text { Multilingual faculty across } \\
\text { academic disciplines: Language } \\
\text { difference in scholarship. } \\
\text { Language and Education, 294), } \\
\text { 317-331. }\end{array}$ & & & & & & & & & & 1 & & & \\
\hline
\end{tabular}




\begin{tabular}{|c|c|c|c|c|c|c|c|c|c|c|c|c|c|}
\hline \multirow[t]{2}{*}{ Titel } & \multicolumn{3}{|c|}{ Holdninger } & \multicolumn{2}{|c|}{ Oplevelse } & \multirow[t]{2}{*}{$\begin{array}{l}\text { Lærings- } \\
\text { udbytte }\end{array}$} & \multirow{2}{*}{$\begin{array}{l}\text { Under- } \\
\text { visning } \\
\text { \& delta- } \\
\text { gelse }\end{array}$} & \multirow{2}{*}{$\begin{array}{l}\text { Problem- } \\
\text { er (fag vs. } \\
\text { sprog) }\end{array}$} & \multirow{2}{*}{$\begin{array}{l}\text { Sprog\& } \\
\text { identi- } \\
\text { tet }\end{array}$} & \multirow{2}{*}{$\begin{array}{l}\text { Sprog- } \\
\text { viden- } \\
\text { skab }\end{array}$} & \multicolumn{2}{|c|}{$\begin{array}{l}\text { Interna- } \\
\text { tionalisering }\end{array}$} & \multirow[t]{2}{*}{$\begin{array}{l}\text { Sprog- } \\
\text { kurser }\end{array}$} \\
\hline & $\begin{array}{l}\text { Stude- } \\
\text { rende }\end{array}$ & $\begin{array}{l}\text { Under- } \\
\text { viser }\end{array}$ & Andre & $\begin{array}{l}\text { Stude- } \\
\text { rende }\end{array}$ & $\begin{array}{l}\text { Under- } \\
\text { viser }\end{array}$ & & & & & & $\begin{array}{l}\text { Sprog- } \\
\text { politik }\end{array}$ & $\begin{array}{l}\text { Studen- } \\
\text { termobi- } \\
\text { litet }\end{array}$ & \\
\hline $\begin{array}{l}\text { Chakrani, B. \& Huang, J. L. } \\
\text { (2014). The work of ideology: } \\
\text { Examining class, language use, } \\
\text { and attitudes among Moroccan } \\
\text { university students. } \\
\text { International Journal of Bilingual } \\
\text { Education and Bilingualism, } \\
1 \pi 1), 1-14 .\end{array}$ & 1 & & & & & & & & 1 & & & & \\
\hline $\begin{array}{l}\text { Chamberlin-Quinlisk, C. (2010). } \\
\text { Language learner/native } \\
\text { speaker interactions: Exploring } \\
\text { adaptability in intercultural } \\
\text { encounters. Intercultural } \\
\text { Education, 21(4), 365-377. }\end{array}$ & & & & & & & & 1 & & & & 1 & \\
\hline $\begin{array}{l}\text { Cheng, L. \& Fox, J. (2008). } \\
\text { Towards a better understanding } \\
\text { of academic acculturation: } \\
\text { Second language students in } \\
\text { Canadian universities. Canadian } \\
\text { Modern Language Review, } \\
\text { 65(2), 307-333. }\end{array}$ & & & & & & & & & & & & 1 & \\
\hline
\end{tabular}




\begin{tabular}{|c|c|c|c|c|c|c|c|c|c|c|c|c|c|}
\hline \multirow[t]{2}{*}{ Titel } & \multicolumn{3}{|c|}{ Holdninger } & \multicolumn{2}{|c|}{ Oplevelse } & \multirow[t]{2}{*}{$\begin{array}{l}\text { Lærings- } \\
\text { udbytte }\end{array}$} & \multirow{2}{*}{$\begin{array}{l}\text { Under- } \\
\text { visning } \\
\& \text { delta- } \\
\text { gelse }\end{array}$} & \multirow{2}{*}{$\begin{array}{l}\text { Problem- } \\
\text { er (fag vs. } \\
\text { sprog) }\end{array}$} & \multirow{2}{*}{$\begin{array}{l}\text { Sprog\& } \\
\text { identi- } \\
\text { tet }\end{array}$} & \multirow{2}{*}{$\begin{array}{l}\text { Sprog- } \\
\text { viden- } \\
\text { skab }\end{array}$} & \multicolumn{2}{|c|}{$\begin{array}{l}\text { Interna- } \\
\text { tionalisering }\end{array}$} & \multirow[t]{2}{*}{$\begin{array}{l}\text { Sprog- } \\
\text { kurser }\end{array}$} \\
\hline & $\begin{array}{l}\text { Stude- } \\
\text { rende }\end{array}$ & $\begin{array}{l}\text { Under- } \\
\text { viser }\end{array}$ & Andre & $\begin{array}{l}\text { Stude- } \\
\text { rende }\end{array}$ & $\begin{array}{l}\text { Under- } \\
\text { viser }\end{array}$ & & & & & & $\begin{array}{l}\text { Sprog- } \\
\text { politik }\end{array}$ & $\begin{array}{l}\text { Studen- } \\
\text { termobi- } \\
\text { litet }\end{array}$ & \\
\hline $\begin{array}{l}\text { Clarence, S., Albertus, L. \& } \\
\text { Mwambene, L. (2014). Building } \\
\text { an evolving method and } \\
\text { materials for teaching legal } \\
\text { writing in large classes. Higher } \\
\text { Education: The International } \\
\text { Journal of Higher Education and } \\
\text { Educational Planning, 676), } \\
\text { 839-851. }\end{array}$ & & & & & & & & 1 & & & & & \\
\hline $\begin{array}{l}\text { Coleman, J. A. (2006). English- } \\
\text { medium teaching in European } \\
\text { Higher education. Language } \\
\text { Teaching, 39(1), 1-14. }\end{array}$ & & & & & & & & & & & 1 & & \\
\hline $\begin{array}{l}\text { Coley, M. (1999). The English } \\
\text { language entry requirements of } \\
\text { Australian universities for } \\
\text { students of non-English } \\
\text { speaking background. Higher } \\
\text { Education Research \& } \\
\text { Development, 18(1), 7-17. }\end{array}$ & & & & & & & & 1 & & & & 1 & \\
\hline
\end{tabular}




\begin{tabular}{|c|c|c|c|c|c|c|c|c|c|c|c|c|c|}
\hline Titel & Holdning & & & Opleve & & $\begin{array}{l}\text { Lærings- } \\
\text { udbytte }\end{array}$ & $\begin{array}{l}\text { Under- } \\
\text { visning }\end{array}$ & $\begin{array}{l}\text { Problem- } \\
\text { er (fag vs. }\end{array}$ & $\begin{array}{l}\text { Sprog\& } \\
\text { identi- }\end{array}$ & $\begin{array}{l}\text { Sprog- } \\
\text { viden- }\end{array}$ & $\begin{array}{l}\text { Interna } \\
\text { tionalis }\end{array}$ & ering & $\begin{array}{l}\text { Sprog- } \\
\text { kurser }\end{array}$ \\
\hline & $\begin{array}{l}\text { Stude- } \\
\text { rende }\end{array}$ & $\begin{array}{l}\text { Under- } \\
\text { viser }\end{array}$ & Andre & $\begin{array}{l}\text { Stude- } \\
\text { rende }\end{array}$ & $\begin{array}{l}\text { Under- } \\
\text { viser }\end{array}$ & & & & & & $\begin{array}{l}\text { Sprog- } \\
\text { politik }\end{array}$ & $\begin{array}{l}\text { Studen- } \\
\text { termobi- } \\
\text { litet }\end{array}$ & \\
\hline $\begin{array}{l}\text { Dafouz, E., Camacho, M. \& } \\
\text { Urquia, E. (2014). "Surely they } \\
\text { can't do as well": A comparison } \\
\text { of business students' academic } \\
\text { performance in English-medium } \\
\text { and Spanish-as-first-language- } \\
\text { medium programmes. Language } \\
\text { and Education, 28(3), 223-236. }\end{array}$ & & & & & & 1 & & & & & & & \\
\hline $\begin{array}{l}\text { Davis, B. D. (2006). Student } \\
\text { perceptions of the acceptance } \\
\text { of communication diverseness. } \\
\text { Journal of Education for } \\
\text { Business, } 82(2), 67-73 \text {. }\end{array}$ & 1 & & & & & & & & & & & & \\
\hline $\begin{array}{l}\text { de Jong, E. (2013). Preparing } \\
\text { mainstream teachers for } \\
\text { multilingual classrooms. Journal } \\
\text { of the Association of Mexican } \\
\text { American Educators, } 72 \text { (2), 40- } \\
49 .\end{array}$ & & & & & & & 1 & & & & & & \\
\hline
\end{tabular}




\begin{tabular}{|c|c|c|c|c|c|c|c|c|c|c|c|c|c|}
\hline Titel & Holdnir & ger & & Oplevels & & $\begin{array}{l}\text { Lærings- } \\
\text { udbytte }\end{array}$ & $\begin{array}{l}\text { Under- } \\
\text { visning }\end{array}$ & $\begin{array}{l}\text { Problem- } \\
\text { er (fag vs. }\end{array}$ & $\begin{array}{l}\text { Sprog\& } \\
\text { identi- }\end{array}$ & $\begin{array}{l}\text { Sprog- } \\
\text { viden- }\end{array}$ & $\begin{array}{l}\text { Interna } \\
\text { tionalis }\end{array}$ & ering & $\begin{array}{l}\text { Sprog- } \\
\text { kurser }\end{array}$ \\
\hline & $\begin{array}{l}\text { Stude- } \\
\text { rende }\end{array}$ & $\begin{array}{l}\text { Under- } \\
\text { viser }\end{array}$ & Andre & $\begin{array}{l}\text { Stude- } \\
\text { rende }\end{array}$ & $\begin{array}{l}\text { Under- } \\
\text { viser }\end{array}$ & & & & & & $\begin{array}{l}\text { Sprog- } \\
\text { politik }\end{array}$ & $\begin{array}{l}\text { Studen- } \\
\text { termobi- } \\
\text { litet }\end{array}$ & \\
\hline $\begin{array}{l}\text { Doiz, A., Lasagabaster, D. \& } \\
\text { Sierra, J. M. (2011). } \\
\text { Internationalization, } \\
\text { multilingualism and English- } \\
\text { medium instruction. World } \\
\text { Englishes, 3a3), 345-359. }\end{array}$ & & 1 & & & & & 1 & & & & & & \\
\hline $\begin{array}{l}\text { Doiz, A., Lasagabaster, D. \& } \\
\text { Sierra, J. M. (2013). } \\
\text { Globalization, } \\
\text { internationalization, } \\
\text { multilingualism and linguistic } \\
\text { strains in higher education. } \\
\text { Studies in Higher Education, } \\
38(9), 1407-1421 .\end{array}$ & 1 & 1 & 1 & & & & & & & & & & \\
\hline $\begin{array}{l}\text { Doiz, A., Lasagabaster, D. \& } \\
\text { Sierra, J. M. (2014). What does } \\
\text { "international university" mean } \\
\text { at a European bilingual } \\
\text { university? The role of } \\
\text { languages and culture. } \\
\text { Language Awareness, 23(1-2), } \\
\text { 172-186. }\end{array}$ & & & & & & & & & & & 1 & & \\
\hline
\end{tabular}




\begin{tabular}{|c|c|c|c|c|c|c|c|c|c|c|c|c|c|}
\hline Titel & Holdning & & & Opleve & & $\begin{array}{l}\text { Lærings- } \\
\text { udbytte }\end{array}$ & $\begin{array}{l}\text { Under- } \\
\text { visning }\end{array}$ & $\begin{array}{l}\text { Problem- } \\
\text { er (fag vs. }\end{array}$ & $\begin{array}{l}\text { Sprog\& } \\
\text { identi- }\end{array}$ & $\begin{array}{l}\text { Sprog- } \\
\text { viden- }\end{array}$ & $\begin{array}{l}\text { Interna } \\
\text { tionalis }\end{array}$ & ering & $\begin{array}{l}\text { Sprog- } \\
\text { kurser }\end{array}$ \\
\hline & $\begin{array}{l}\text { Stude- } \\
\text { rende }\end{array}$ & $\begin{array}{l}\text { Under- } \\
\text { viser }\end{array}$ & Andre & $\begin{array}{l}\text { Stude- } \\
\text { rende }\end{array}$ & $\begin{array}{l}\text { Under- } \\
\text { viser }\end{array}$ & & & & & & $\begin{array}{l}\text { Sprog- } \\
\text { politik }\end{array}$ & $\begin{array}{l}\text { Studen- } \\
\text { termobi- } \\
\text { litet }\end{array}$ & \\
\hline $\begin{array}{l}\text { Earls, C. W. (2014). Striking the } \\
\text { balance: The role of English and } \\
\text { German in a multilingual } \\
\text { English-medium degree } \\
\text { programme in German higher } \\
\text { education. Current Issues in } \\
\text { Language Planning, 15(2),153- } \\
173 .\end{array}$ & & & & 1 & & & & & & & & & \\
\hline $\begin{array}{l}\text { Evans, S. \& Morrison, B. (2011). } \\
\text { The student experience of } \\
\text { English-medium higher } \\
\text { education in Hong Kong. } \\
\text { Language and Education, 25(2), } \\
\text { 147-162. }\end{array}$ & & & & & & & & 1 & & & 1 & & \\
\hline $\begin{array}{l}\text { Evans, S. \& Morrison, B. (2011). } \\
\text { Meeting the challenges of } \\
\text { English-medium higher } \\
\text { education: The first-year } \\
\text { experience in Hong Kong. } \\
\text { English for Specific Purposes, } \\
\text { 3a3), 198-208. }\end{array}$ & & & & & & & & & & & & & \\
\hline
\end{tabular}




\begin{tabular}{|c|c|c|c|c|c|c|c|c|c|c|c|c|c|}
\hline \multirow[t]{2}{*}{ Titel } & \multicolumn{3}{|c|}{ Holdninger } & \multicolumn{2}{|c|}{ Oplevelse } & \multirow[t]{2}{*}{$\begin{array}{l}\text { Lærings- } \\
\text { udbytte }\end{array}$} & \multirow{2}{*}{$\begin{array}{l}\text { Under- } \\
\text { visning\& } \\
\text { delta- } \\
\text { gelse }\end{array}$} & \multirow{2}{*}{$\begin{array}{l}\text { Problem- } \\
\text { er (fag vs. } \\
\text { sprog) }\end{array}$} & \multirow{2}{*}{$\begin{array}{l}\text { Sprog\& } \\
\text { identi- } \\
\text { tet }\end{array}$} & \multirow{2}{*}{$\begin{array}{l}\text { Sprog- } \\
\text { viden- } \\
\text { skab }\end{array}$} & \multicolumn{2}{|c|}{$\begin{array}{l}\text { Interna- } \\
\text { tionalisering }\end{array}$} & \multirow[t]{2}{*}{$\begin{array}{l}\text { Sprog- } \\
\text { kurser }\end{array}$} \\
\hline & $\begin{array}{l}\text { Stude- } \\
\text { rende }\end{array}$ & $\begin{array}{l}\text { Under- } \\
\text { viser }\end{array}$ & Andre & $\begin{array}{l}\text { Stude- } \\
\text { rende }\end{array}$ & $\begin{array}{l}\text { Under- } \\
\text { viser }\end{array}$ & & & & & & $\begin{array}{l}\text { Sprog- } \\
\text { politik }\end{array}$ & $\begin{array}{l}\text { Studen- } \\
\text { termobi- } \\
\text { litet }\end{array}$ & \\
\hline $\begin{array}{l}\text { Findlow, S. (2006). Higher } \\
\text { education and linguistic dualism } \\
\text { in the Arab Gulf. British Journal } \\
\text { of Sociology of Education, } \\
2 \pi(1), 19-36 \text {. }\end{array}$ & & & & & & & & & 1 & & & & \\
\hline $\begin{array}{l}\text { Floris, D. F. (2014). Learning } \\
\text { subject matter through English } \\
\text { as the medium of instruction: } \\
\text { students' and teachers' } \\
\text { perspectives. Asian Englishes, } \\
\text { 16(1), 47-59. }\end{array}$ & 1 & 1 & & & & & & & & & & & \\
\hline $\begin{array}{l}\text { Flowerdew, J. \& Miller, L. } \\
\text { (1996). Lectures in a second } \\
\text { language: Notes towards a } \\
\text { cultural grammar. English for } \\
\text { Specific Purposes, } 15(2), 121- \\
140 .\end{array}$ & 1 & 1 & & & & & & & & & & & \\
\hline
\end{tabular}




\begin{tabular}{|c|c|c|c|c|c|c|c|c|c|c|c|c|c|}
\hline \multirow[t]{2}{*}{ Titel } & \multicolumn{3}{|c|}{ Holdninger } & \multicolumn{2}{|c|}{ Oplevelse } & \multirow[t]{2}{*}{$\begin{array}{l}\text { Lærings- } \\
\text { udbytte }\end{array}$} & \multirow{2}{*}{$\begin{array}{l}\text { Under- } \\
\text { visning } \\
\& \text { delta- } \\
\text { gelse }\end{array}$} & \multirow{2}{*}{$\begin{array}{l}\text { Problem- } \\
\text { er (fag vs. } \\
\text { sprog) }\end{array}$} & \multirow{2}{*}{$\begin{array}{l}\text { Sprog\& } \\
\text { identi- } \\
\text { tet }\end{array}$} & \multirow{2}{*}{$\begin{array}{l}\text { Sprog- } \\
\text { viden- } \\
\text { skab }\end{array}$} & \multicolumn{2}{|c|}{$\begin{array}{l}\text { Interna- } \\
\text { tionalisering }\end{array}$} & \multirow[t]{2}{*}{$\begin{array}{l}\text { Sprog- } \\
\text { kurser }\end{array}$} \\
\hline & $\begin{array}{l}\text { Stude- } \\
\text { rende }\end{array}$ & $\begin{array}{l}\text { Under- } \\
\text { viser }\end{array}$ & Andre & $\begin{array}{l}\text { Stude- } \\
\text { rende }\end{array}$ & $\begin{array}{l}\text { Under- } \\
\text { viser }\end{array}$ & & & & & & $\begin{array}{l}\text { Sprog- } \\
\text { politik }\end{array}$ & $\begin{array}{l}\text { Studen- } \\
\text { termobi- } \\
\text { litet }\end{array}$ & \\
\hline $\begin{array}{l}\text { Garner, M. \& Borg, E. (2005). } \\
\text { An ecological perspective on } \\
\text { content-based instruction. } \\
\text { Journal of English for Academic } \\
\text { Purposes, } 4(2), 119-134 .\end{array}$ & & & & & & & & & & & & & 1 \\
\hline $\begin{array}{l}\text { Gerber, A., Engelbrecht, J., } \\
\text { Harding, A. \& Rogan, J. (2005). } \\
\text { The influence of second } \\
\text { language teaching on } \\
\text { undergraduate mathematics } \\
\text { performance. Mathematics } \\
\text { Education Research Journal } \\
1 \pi(3), 3-21 .\end{array}$ & & & & & & 1 & & & & & & & \\
\hline $\begin{array}{l}\text { Ghorbani, M. R. \& Alavi, S. Z. } \\
\text { (2014). Feasibility of adopting } \\
\text { English-medium instruction at } \\
\text { I ranian universities. Current } \\
\text { Issues in Education, 171). }\end{array}$ & 1 & 1 & & & & & & & & & & & \\
\hline
\end{tabular}




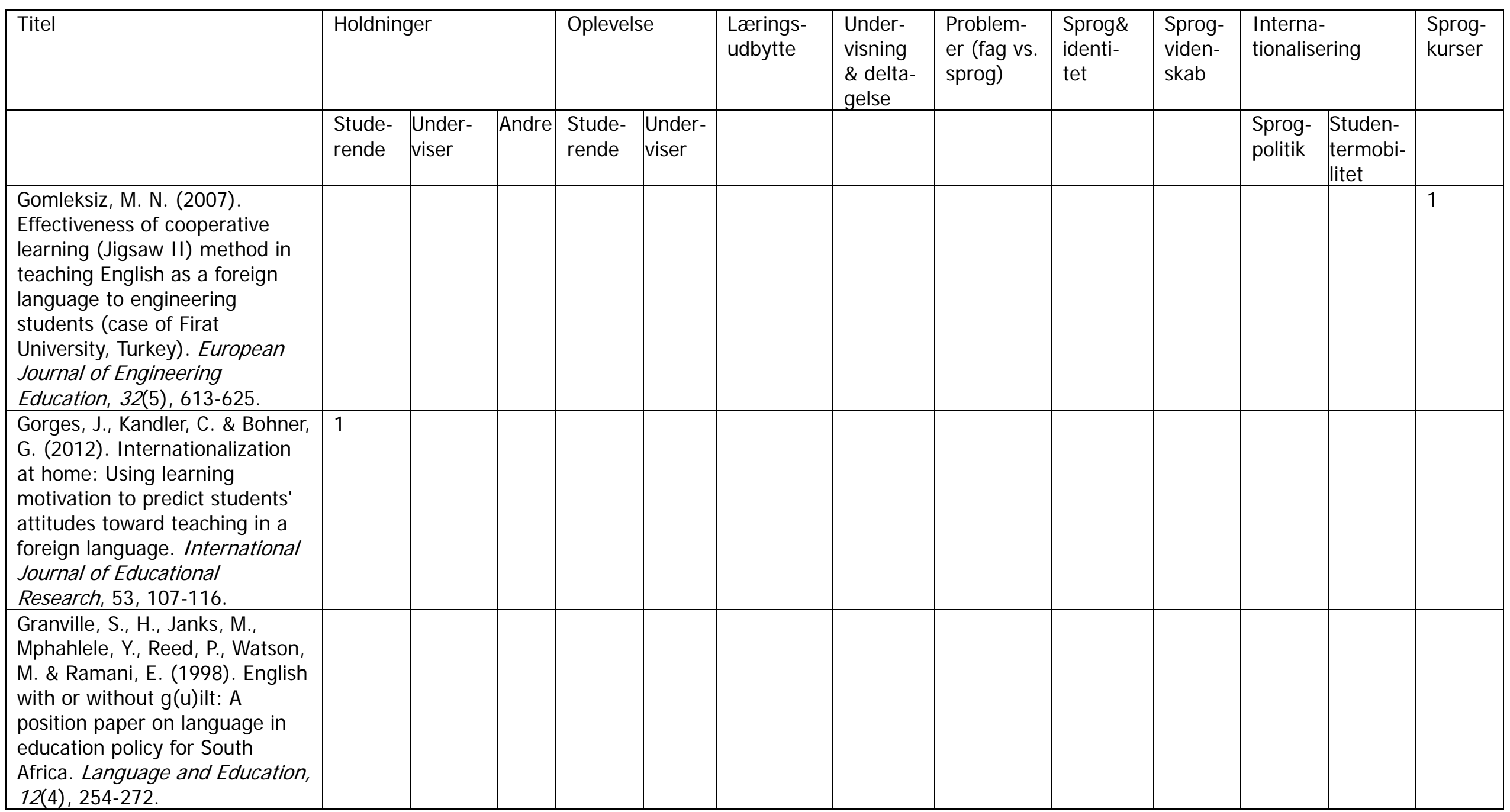




\begin{tabular}{|c|c|c|c|c|c|c|c|c|c|c|c|c|c|}
\hline \multirow[t]{2}{*}{ Titel } & \multicolumn{3}{|c|}{ Holdninger } & \multicolumn{2}{|c|}{ Oplevelse } & \multirow[t]{2}{*}{$\begin{array}{l}\text { Lærings- } \\
\text { udbytte }\end{array}$} & \multirow{2}{*}{$\begin{array}{l}\text { Under- } \\
\text { visning } \\
\& \text { delta- } \\
\text { gelse }\end{array}$} & \multirow{2}{*}{$\begin{array}{l}\text { Problem- } \\
\text { er (fag vs. } \\
\text { sprog) }\end{array}$} & \multirow{2}{*}{$\begin{array}{l}\text { Sprog\& } \\
\text { identi- } \\
\text { tet }\end{array}$} & \multirow{2}{*}{$\begin{array}{l}\text { Sprog- } \\
\text { viden- } \\
\text { skab }\end{array}$} & \multicolumn{2}{|c|}{$\begin{array}{l}\text { Interna- } \\
\text { tionalisering }\end{array}$} & \multirow[t]{2}{*}{$\begin{array}{l}\text { Sprog- } \\
\text { kurser }\end{array}$} \\
\hline & $\begin{array}{l}\text { Stude- } \\
\text { rende }\end{array}$ & $\begin{array}{l}\text { Under- } \\
\text { viser }\end{array}$ & Andre & $\begin{array}{l}\text { Stude- } \\
\text { rende }\end{array}$ & $\begin{array}{l}\text { Under- } \\
\text { viser }\end{array}$ & & & & & & $\begin{array}{l}\text { Sprog- } \\
\text { politik }\end{array}$ & $\begin{array}{l}\text { Studen- } \\
\text { termobi- } \\
\text { litet }\end{array}$ & \\
\hline $\begin{array}{l}\text { Gu, M. M. \& Tong, H. K. (2012). } \\
\text { Space, scale and languages: } \\
\text { identity construction of cross- } \\
\text { boundary students in a } \\
\text { multilingual university in Hong } \\
\text { Kong. Language and Education } \\
\text { 266), 501-515. }\end{array}$ & & & & & & & & & 1 & & & & \\
\hline $\begin{array}{l}\text { Hamid, M. O., J ahan, I. \& Islam, } \\
\text { M. M. (2013). Medium of } \\
\text { instruction policies and } \\
\text { language practices, ideologies } \\
\text { and institutional divides: Voices } \\
\text { of teachers and students in a } \\
\text { private university in Bangladesh. } \\
\text { Current Issues in Language } \\
\text { Planning, 14(1), 144-163. }\end{array}$ & 1 & 1 & & & & & & & & & 1 & & \\
\hline
\end{tabular}




\begin{tabular}{|c|c|c|c|c|c|c|c|c|c|c|c|c|c|}
\hline Titel & Holdning & iger & & Oplevels & & $\begin{array}{l}\text { Lærings- } \\
\text { udbytte }\end{array}$ & $\begin{array}{l}\text { Under- } \\
\text { visning }\end{array}$ & $\begin{array}{l}\text { Problem- } \\
\text { er (fag vs. }\end{array}$ & $\begin{array}{l}\text { Sprog\& } \\
\text { identi- }\end{array}$ & $\begin{array}{l}\text { Sprog- } \\
\text { viden- }\end{array}$ & $\begin{array}{l}\text { Interna } \\
\text { tionalis }\end{array}$ & ering & $\begin{array}{l}\text { Sprog- } \\
\text { kurser }\end{array}$ \\
\hline & $\begin{array}{l}\text { Stude- } \\
\text { rende }\end{array}$ & $\begin{array}{l}\text { Under- } \\
\text { viser }\end{array}$ & Andre & $\begin{array}{l}\text { Stude- } \\
\text { rende }\end{array}$ & $\begin{array}{l}\text { Under- } \\
\text { viser }\end{array}$ & & & & & & $\begin{array}{l}\text { Sprog- } \\
\text { politik }\end{array}$ & $\begin{array}{l}\text { Studen- } \\
\text { termobi- } \\
\text { litet }\end{array}$ & \\
\hline $\begin{array}{l}\text { Hardwick, S. W. \& Davis, R. L. } \\
\text { (2009). Content-based language } \\
\text { instruction: A new window of } \\
\text { opportunity in geography } \\
\text { education. Journal of } \\
\text { Geography, 108(4-5), 163-173. }\end{array}$ & & & & & & & & & & & & & 1 \\
\hline $\begin{array}{l}\text { Hellstén, M. \& Prescott, A. } \\
\text { (2004). Learning at university: } \\
\text { The international student } \\
\text { experience. International } \\
\text { Education Journal, 5(3), 344- } \\
\text { 351. }\end{array}$ & & & & & & & & & & & & 1 & \\
\hline $\begin{array}{l}\text { Harrison, S. \& Morgan, R. } \\
\text { (2012). Using simplified English } \\
\text { to identify potential problems } \\
\text { for non-native speakers in the } \\
\text { language of engineering } \\
\text { examination papers. Language } \\
\text { Learning Journal, 4a(1), 113- } \\
123 .\end{array}$ & & & & & & & & 1 & & & & & \\
\hline
\end{tabular}




\begin{tabular}{|c|c|c|c|c|c|c|c|c|c|c|c|c|c|}
\hline \multirow[t]{2}{*}{ Titel } & \multicolumn{3}{|c|}{ Holdninger } & \multicolumn{2}{|c|}{ Oplevelse } & \multirow{2}{*}{$\begin{array}{l}\text { Læ- } \\
\text { rings- } \\
\text { udbyt- } \\
\text { te }\end{array}$} & \multirow{2}{*}{$\begin{array}{l}\text { Under- } \\
\text { visning } \\
\& \text { delta- } \\
\text { gelse }\end{array}$} & \multirow{2}{*}{$\begin{array}{l}\text { Problem- } \\
\text { er (fag vs. } \\
\text { sprog) }\end{array}$} & \multirow{2}{*}{$\begin{array}{l}\text { Sprog\& } \\
\text { identi- } \\
\text { tet }\end{array}$} & \multirow{2}{*}{$\begin{array}{l}\text { Sprog- } \\
\text { viden- } \\
\text { skab }\end{array}$} & \multicolumn{2}{|c|}{$\begin{array}{l}\text { Interna- } \\
\text { tionalisering }\end{array}$} & \multirow[t]{2}{*}{$\begin{array}{l}\text { Sprog- } \\
\text { kurser }\end{array}$} \\
\hline & $\begin{array}{l}\text { Stude- } \\
\text { rende }\end{array}$ & $\begin{array}{l}\text { Under- } \\
\text { viser }\end{array}$ & Andre & $\begin{array}{l}\text { Stude- } \\
\text { rende }\end{array}$ & $\begin{array}{l}\text { Under- } \\
\text { viser }\end{array}$ & & & & & & $\begin{array}{l}\text { Sprog- } \\
\text { politik }\end{array}$ & $\begin{array}{l}\text { Studen- } \\
\text { termobi- } \\
\text { litet }\end{array}$ & \\
\hline $\begin{array}{l}\text { Hellstén, M. \& Prescott, A. } \\
\text { (2004). Learning at university: } \\
\text { The international student } \\
\text { experience. International } \\
\text { Education Journal, 5(3), 344- } \\
351 .\end{array}$ & & & & & & & & & & & & & \\
\hline $\begin{array}{l}\text { Henderson, J. (2009). "It's all } \\
\text { about give and take," or is it? } \\
\text { Where, when and how do } \\
\text { native and non-native uses of } \\
\text { English shape U.K. university } \\
\text { students' representations of } \\
\text { each other and their learning } \\
\text { experience. Journal of Studies } \\
\text { in International Education, } \\
\text { 13(3), 398-409. }\end{array}$ & & & & 1 & & & & & 1 & & & 1 & \\
\hline
\end{tabular}




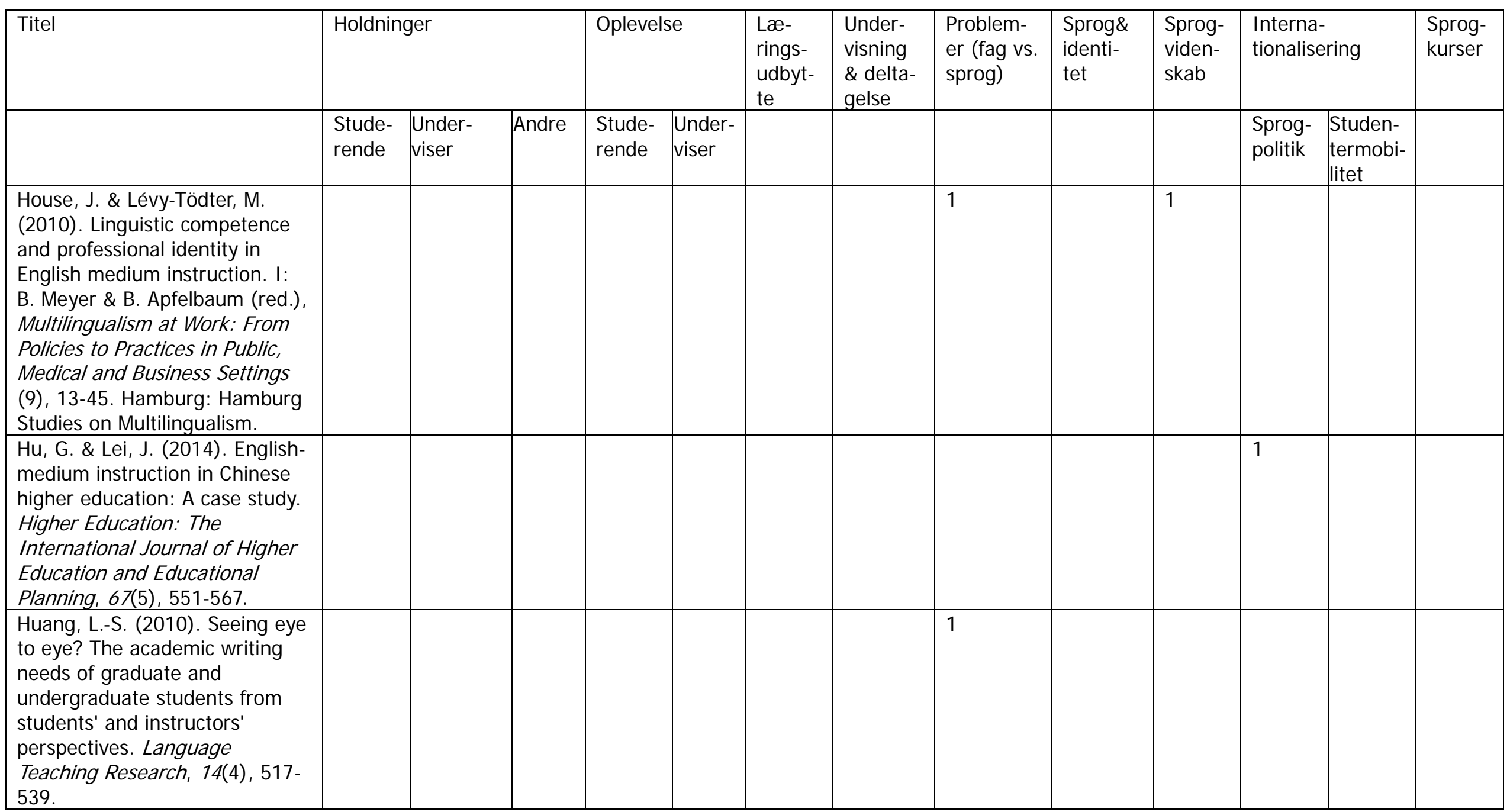




\begin{tabular}{|c|c|c|c|c|c|c|c|c|c|c|c|c|c|}
\hline \multirow[t]{2}{*}{ Titel } & \multicolumn{3}{|c|}{ Holdninger } & \multicolumn{2}{|c|}{ Oplevelse } & \multirow{2}{*}{$\begin{array}{l}\text { Læ- } \\
\text { rings- } \\
\text { udbyt- } \\
\text { te }\end{array}$} & \multirow{2}{*}{$\begin{array}{l}\text { Under- } \\
\text { visning } \\
\& \text { delta- } \\
\text { gelse }\end{array}$} & \multirow{2}{*}{$\begin{array}{l}\text { Problem- } \\
\text { er (fag vs. } \\
\text { sprog) }\end{array}$} & \multirow{2}{*}{$\begin{array}{l}\text { Sprog\& } \\
\text { identi- } \\
\text { tet }\end{array}$} & \multirow{2}{*}{$\begin{array}{l}\text { Sprog- } \\
\text { viden- } \\
\text { skab }\end{array}$} & \multicolumn{2}{|c|}{$\begin{array}{l}\text { Interna- } \\
\text { tionalisering }\end{array}$} & \multirow[t]{2}{*}{$\begin{array}{l}\text { Sprog- } \\
\text { kurser }\end{array}$} \\
\hline & $\begin{array}{l}\text { Stude- } \\
\text { rende }\end{array}$ & $\begin{array}{l}\text { Under- } \\
\text { viser }\end{array}$ & Andre & $\begin{array}{l}\text { Stude- } \\
\text { rende }\end{array}$ & $\begin{array}{l}\text { Under- } \\
\text { viser }\end{array}$ & & & & & & $\begin{array}{l}\text { Sprog- } \\
\text { politik }\end{array}$ & $\begin{array}{l}\text { Studen- } \\
\text { termobi- } \\
\text { litet }\end{array}$ & \\
\hline $\begin{array}{l}\text { Hurst, E. (2015). "The thing } \\
\text { that kill us": Student } \\
\text { perspectives on language } \\
\text { support in a South African } \\
\text { university. Teaching in Higher } \\
\text { Education, 2a1), 78-91. }\end{array}$ & & & & & & & & 1 & & & & & \\
\hline $\begin{array}{l}\text { Hynninen, N. (2012): ICL at the } \\
\text { micro level: } L 2 \text { speakers taking } \\
\text { on the role of language experts. } \\
\text { AILA Review, } 25,13-29 \text {. }\end{array}$ & & & & & & & & & 1 & 1 & & & \\
\hline $\begin{array}{l}\text { I ppolito, K. (2007). Promoting } \\
\text { intercultural learning in a } \\
\text { multicultural university: Ideals } \\
\text { and realities. Teaching in Higher } \\
\text { Education, 12(5-6), 749-763 }\end{array}$ & & & & & & & & & & & & 1 & \\
\hline
\end{tabular}




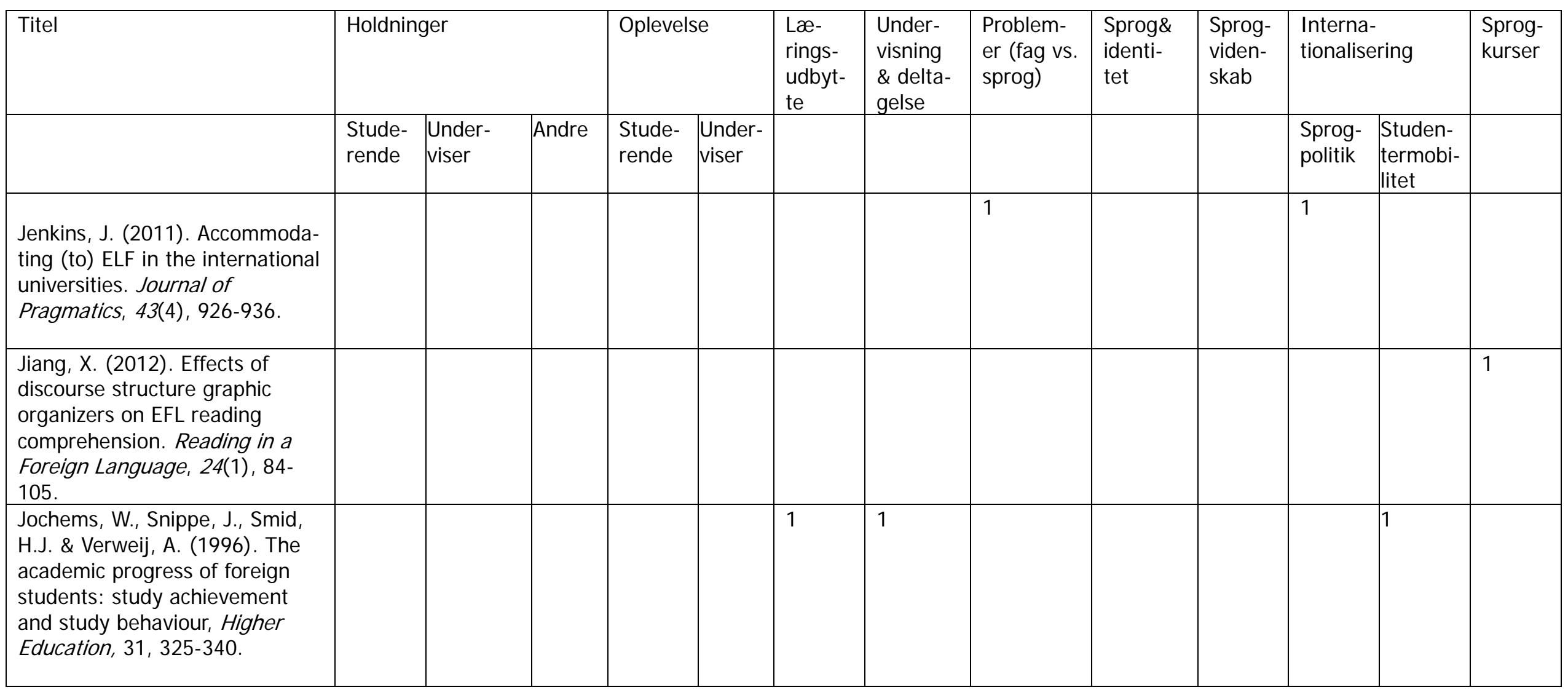




\begin{tabular}{|c|c|c|c|c|c|c|c|c|c|c|c|c|c|}
\hline Titel & Holdnin & iger & & Opleve & & $\begin{array}{l}\text { Læ- } \\
\text { rings- }\end{array}$ & $\begin{array}{l}\text { Under- } \\
\text { visning }\end{array}$ & $\begin{array}{l}\text { Problem- } \\
\text { er (fag vs. }\end{array}$ & $\begin{array}{l}\text { Sprog\& } \\
\text { identi- }\end{array}$ & $\begin{array}{l}\text { Sprog- } \\
\text { viden- }\end{array}$ & $\begin{array}{l}\text { Interna } \\
\text { tionalis }\end{array}$ & ering & $\begin{array}{l}\text { Sprog- } \\
\text { kurser }\end{array}$ \\
\hline & $\begin{array}{l}\text { Stude- } \\
\text { rende }\end{array}$ & $\begin{array}{l}\text { Under- } \\
\text { viser }\end{array}$ & Andre & $\begin{array}{l}\text { Stude- } \\
\text { rende }\end{array}$ & $\begin{array}{l}\text { Under- } \\
\text { viser }\end{array}$ & & & & & & $\begin{array}{l}\text { Sprog- } \\
\text { politik }\end{array}$ & $\begin{array}{l}\text { Studen- } \\
\text { termobi- } \\
\text { litet }\end{array}$ & \\
\hline $\begin{array}{l}\text { J on, J.-E., Lee, J. J. \& Byun, K. } \\
\text { (2014). The emergence of a } \\
\text { regional hub: Comparing } \\
\text { international student choices } \\
\text { and experiences in South Korea. } \\
\text { Higher Education: The } \\
\text { International Journal of Higher } \\
\text { Education and Educational } \\
\text { Planning, 675), 691-710. }\end{array}$ & & & & & & & & & & & & 1 & \\
\hline $\begin{array}{l}\text { Kaloscai, K. (2009). Erasmus } \\
\text { exchange students: A behind- } \\
\text { the-scenes view into an ELF } \\
\text { community of practice. Apples - } \\
\text { Journal of Applied Language } \\
\text { Studies, 3(1), 25-49. }\end{array}$ & & & & & & & & & & & & 1 & \\
\hline $\begin{array}{l}\text { Kane, T. (2014). Whose lingua } \\
\text { franca? The politics of language } \\
\text { in transnational medical } \\
\text { education. Journal of General } \\
\text { Education, } 63(2-3), 94-112 \text {. }\end{array}$ & & & & & & & 1 & & 1 & & 1 & & \\
\hline
\end{tabular}




\begin{tabular}{|c|c|c|c|c|c|c|c|c|c|c|c|c|c|}
\hline \multirow[t]{2}{*}{ Titel } & \multicolumn{3}{|c|}{ Holdninger } & \multicolumn{2}{|c|}{ Oplevelse } & \multirow{2}{*}{$\begin{array}{l}\text { Læ- } \\
\text { rings- } \\
\text { udbyt- } \\
\text { te }\end{array}$} & \multirow{2}{*}{$\begin{array}{l}\text { Under- } \\
\text { visning } \\
\& \text { delta- } \\
\text { gelse }\end{array}$} & \multirow{2}{*}{$\begin{array}{l}\text { Problem- } \\
\text { er (fag vs. } \\
\text { sprog) }\end{array}$} & \multirow{2}{*}{$\begin{array}{l}\text { Sprog\& } \\
\text { identi- } \\
\text { tet }\end{array}$} & \multirow{2}{*}{$\begin{array}{l}\text { Sprog- } \\
\text { viden- } \\
\text { skab }\end{array}$} & \multicolumn{2}{|c|}{$\begin{array}{l}\text { Interna- } \\
\text { tionalisering }\end{array}$} & \multirow[t]{2}{*}{$\begin{array}{l}\text { Sprog- } \\
\text { kurser }\end{array}$} \\
\hline & $\begin{array}{l}\text { Stude- } \\
\text { rende }\end{array}$ & $\begin{array}{l}\text { Under- } \\
\text { viser }\end{array}$ & Andre & $\begin{array}{l}\text { Stude- } \\
\text { rende }\end{array}$ & $\begin{array}{l}\text { Under- } \\
\text { viser }\end{array}$ & & & & & & $\begin{array}{l}\text { Sprog- } \\
\text { politik }\end{array}$ & $\begin{array}{l}\text { Studen- } \\
\text { termobi- } \\
\text { litet }\end{array}$ & \\
\hline $\begin{array}{l}\text { Karathanos, K. A. \& Mena, D. D. } \\
\text { (2014). Exploring the } \\
\text { experiences of linguistically } \\
\text { diverse college of education } \\
\text { student writers. Journal of } \\
\text { University Teaching and } \\
\text { Learning Practice, 11(3). }\end{array}$ & & & & & & & & 1 & & & & & \\
\hline $\begin{array}{l}\text { Kember, D., Sandra, N. G., } \\
\text { Harrison, T. S. E., Wong, E. T. } \\
\text { T. \& Pomfret, M. (1996). An } \\
\text { examination of the } \\
\text { interrelationships between } \\
\text { workload, study time, learning } \\
\text { approaches and academic } \\
\text { outcomes. Studies in Higher } \\
\text { Education, 21(3), 347-358. }\end{array}$ & & & & & & 1 & & 1 & & & & & \\
\hline $\begin{array}{l}\text { Kiliçkaya, F. (2006). Instructors' } \\
\text { attitudes toward English- } \\
\text { medium instruction in Turkey. } \\
\text { Humanising Language Teaching, } \\
\text { \&6). }\end{array}$ & & 1 & & & & & & & & & & & \\
\hline
\end{tabular}




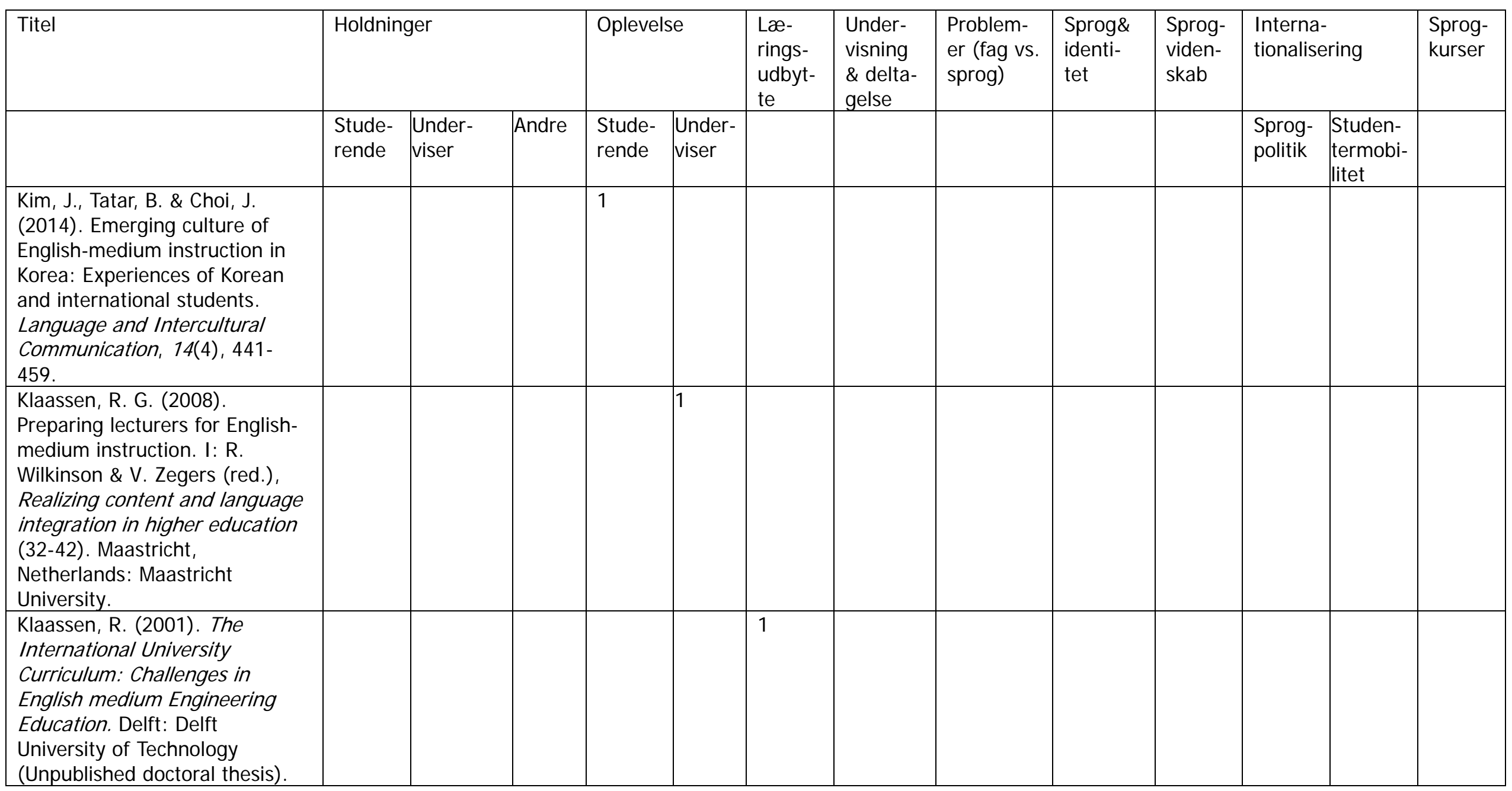




\begin{tabular}{|c|c|c|c|c|c|c|c|c|c|c|c|c|c|}
\hline \multirow[t]{2}{*}{ Titel } & \multicolumn{3}{|c|}{ Holdninger } & \multicolumn{2}{|c|}{ Oplevelse } & \multirow{2}{*}{$\begin{array}{l}\text { Læ- } \\
\text { rings- } \\
\text { udbyt- } \\
\text { te }\end{array}$} & \multirow{2}{*}{$\begin{array}{l}\text { Under- } \\
\text { visning } \\
\text { \& delta- } \\
\text { gelse }\end{array}$} & \multirow{2}{*}{$\begin{array}{l}\text { Problem- } \\
\text { er (fag vs. } \\
\text { sprog) }\end{array}$} & \multirow{2}{*}{$\begin{array}{l}\text { Sprog\& } \\
\text { identi- } \\
\text { tet }\end{array}$} & \multirow{2}{*}{$\begin{array}{l}\text { Sprog- } \\
\text { viden- } \\
\text { skab }\end{array}$} & \multicolumn{2}{|c|}{$\begin{array}{l}\text { Interna- } \\
\text { tionalisering }\end{array}$} & \multirow[t]{2}{*}{$\begin{array}{l}\text { Sprog- } \\
\text { kurser }\end{array}$} \\
\hline & $\begin{array}{l}\text { Stude- } \\
\text { rende }\end{array}$ & $\begin{array}{l}\text { Under- } \\
\text { viser }\end{array}$ & Andre & $\begin{array}{l}\text { Stude- } \\
\text { rende }\end{array}$ & $\begin{array}{l}\text { Under- } \\
\text { viser }\end{array}$ & & & & & & $\begin{array}{l}\text { Sprog- } \\
\text { politik }\end{array}$ & $\begin{array}{l}\text { Studen- } \\
\text { termobi- } \\
\text { litet }\end{array}$ & \\
\hline $\begin{array}{l}\text { Kormos, J., Csizér, K \& I waniec, } \\
\text { J. (2014). A mixed-method } \\
\text { study of language-learning } \\
\text { motivation and intercultural } \\
\text { contact of international } \\
\text { students. Journal of Multilingual } \\
\text { and Multicultural Development, } \\
\text { 35(2), 151-166. }\end{array}$ & & & & & & & & & & & & 1 & \\
\hline $\begin{array}{l}\text { Kuroda, C. (2014). The new } \\
\text { sphere of international student } \\
\text { education in Chinese higher } \\
\text { education: A focus on English- } \\
\text { medium degree programs. } \\
\text { Journal of Studies in } \\
\text { International Education, 18(5), } \\
\text { 445-462. }\end{array}$ & & & & & & & & & & & 1 & 1 & \\
\hline $\begin{array}{l}\text { Kyeyune, R. (2003). Challenges } \\
\text { of using English as a medium of } \\
\text { instruction in multilingual } \\
\text { contexts: A View from Ugandan } \\
\text { classrooms. Language, Culture } \\
\text { and Curriculum, 16(2), 173-184. }\end{array}$ & & & & & & & 1 & 1 & & & & & \\
\hline
\end{tabular}




\begin{tabular}{|c|c|c|c|c|c|c|c|c|c|c|c|c|c|}
\hline Titel & Holdnir & & & Oplevel & & $\begin{array}{l}\text { Læ- } \\
\text { rings- }\end{array}$ & $\begin{array}{l}\text { Under- } \\
\text { visning }\end{array}$ & $\begin{array}{l}\text { Problem- } \\
\text { er (fag vs. }\end{array}$ & $\begin{array}{l}\text { Sprog\& } \\
\text { identi- }\end{array}$ & $\begin{array}{l}\text { Sprog- } \\
\text { viden- }\end{array}$ & $\begin{array}{l}\text { Interna } \\
\text { tionalis }\end{array}$ & ering & $\begin{array}{l}\text { Sprog- } \\
\text { kurser }\end{array}$ \\
\hline & $\begin{array}{l}\text { Stude- } \\
\text { rende }\end{array}$ & $\begin{array}{l}\text { Under- } \\
\text { viser }\end{array}$ & Andre & $\begin{array}{l}\text { Stude- } \\
\text { rende }\end{array}$ & $\begin{array}{l}\text { Under- } \\
\text { viser }\end{array}$ & & & & & & $\begin{array}{l}\text { Sprog- } \\
\text { politik }\end{array}$ & $\begin{array}{l}\text { Studen- } \\
\text { termobi- } \\
\text { litet }\end{array}$ & \\
\hline $\begin{array}{l}\text { Lasagabaster, D., Cots, J. M. \& } \\
\text { Mancho-Barés, G. (2013). } \\
\text { Teaching staff's views about the } \\
\text { internationalisation of higher } \\
\text { education: The case of two } \\
\text { bilingual communities in Spain. } \\
\text { Multilingua: Journal of Cross- } \\
\text { Cultural and Interlanguage } \\
\text { Communication, 32(6), 751- } \\
778 \text {. }\end{array}$ & & 1 & & & & & & & & & & 1 & \\
\hline $\begin{array}{l}\text { Le Phan, H. (2013). Issues } \\
\text { surrounding English, the } \\
\text { internationalization of higher } \\
\text { education and national cultural } \\
\text { identity in Asia: A focus on } \\
\text { J apan. Critical Studies in } \\
\text { Education, 54(2), 160-175. }\end{array}$ & & & & & & & & & & & 1 & & \\
\hline $\begin{array}{l}\text { Lee, B., Farruggia, S. P. \& } \\
\text { Brown, G. T. L. (2013). } \\
\text { Academic difficulties } \\
\text { encountered by East Asian } \\
\text { international university students } \\
\text { in New Zealand. Higher } \\
\text { Education Research and } \\
\text { Development, 32(6), 915-931. }\end{array}$ & & & & & & & & 1 & & & & 1 & \\
\hline
\end{tabular}




\begin{tabular}{|c|c|c|c|c|c|c|c|c|c|c|c|c|c|}
\hline \multirow[t]{2}{*}{ Titel } & \multicolumn{3}{|c|}{ Holdninger } & \multicolumn{2}{|c|}{ Oplevelse } & \multirow{2}{*}{$\begin{array}{l}\text { Læ- } \\
\text { rings- } \\
\text { udbyt- } \\
\text { te }\end{array}$} & \multirow{2}{*}{$\begin{array}{l}\text { Under- } \\
\text { visning } \\
\& \text { delta- } \\
\text { gelse }\end{array}$} & \multirow{2}{*}{$\begin{array}{l}\text { Problem- } \\
\text { er (fag vs. } \\
\text { sprog) }\end{array}$} & \multirow{2}{*}{$\begin{array}{l}\text { Sprog\& } \\
\text { identi- } \\
\text { tet }\end{array}$} & \multirow{2}{*}{$\begin{array}{l}\text { Sprog- } \\
\text { viden- } \\
\text { skab }\end{array}$} & \multicolumn{2}{|c|}{$\begin{array}{l}\text { Interna- } \\
\text { tionalisering }\end{array}$} & \multirow[t]{2}{*}{$\begin{array}{l}\text { Sprog- } \\
\text { kurser }\end{array}$} \\
\hline & $\begin{array}{l}\text { Stude- } \\
\text { rende }\end{array}$ & $\begin{array}{l}\text { Under- } \\
\text { viser }\end{array}$ & Andre & $\begin{array}{l}\text { Stude- } \\
\text { rende }\end{array}$ & $\begin{array}{l}\text { Under- } \\
\text { viser }\end{array}$ & & & & & & $\begin{array}{l}\text { Sprog- } \\
\text { politik }\end{array}$ & \begin{tabular}{|l|} 
Studen- \\
termobi- \\
litet
\end{tabular} & \\
\hline $\begin{array}{l}\text { Lee, H. (2014). Measuring } \\
\text { cognitive load with } \\
\text { electroencephalography and } \\
\text { self-report: Focus on the effect } \\
\text { of English-medium learning for } \\
\text { Korean students. Educational } \\
\text { Psychology, 34(7), 838-848. }\end{array}$ & & & & & & 1 & & & & & & & \\
\hline $\begin{array}{l}\text { Lin, L. H. F. \& Morrison, B. } \\
\text { (2010). The impact of the } \\
\text { medium of instruction in Hong } \\
\text { Kong secondary schools on } \\
\text { tertiary students' vocabulary. } \\
\text { Journal of English for Academic } \\
\text { Purposes, } 94 \text { (4), 255-266. }\end{array}$ & & & & & & & & 1 & & & 1 & & \\
\hline $\begin{array}{l}\text { Liu, M. \& J ackson, J. (2008). An } \\
\text { exploration of Chinese EFL } \\
\text { learners' unwillingness to } \\
\text { communicate and foreign } \\
\text { language anxiety. Modern } \\
\text { Language Journal, 92(1), 71-86. }\end{array}$ & & & & & & & 1 & 1 & & & & & \\
\hline
\end{tabular}




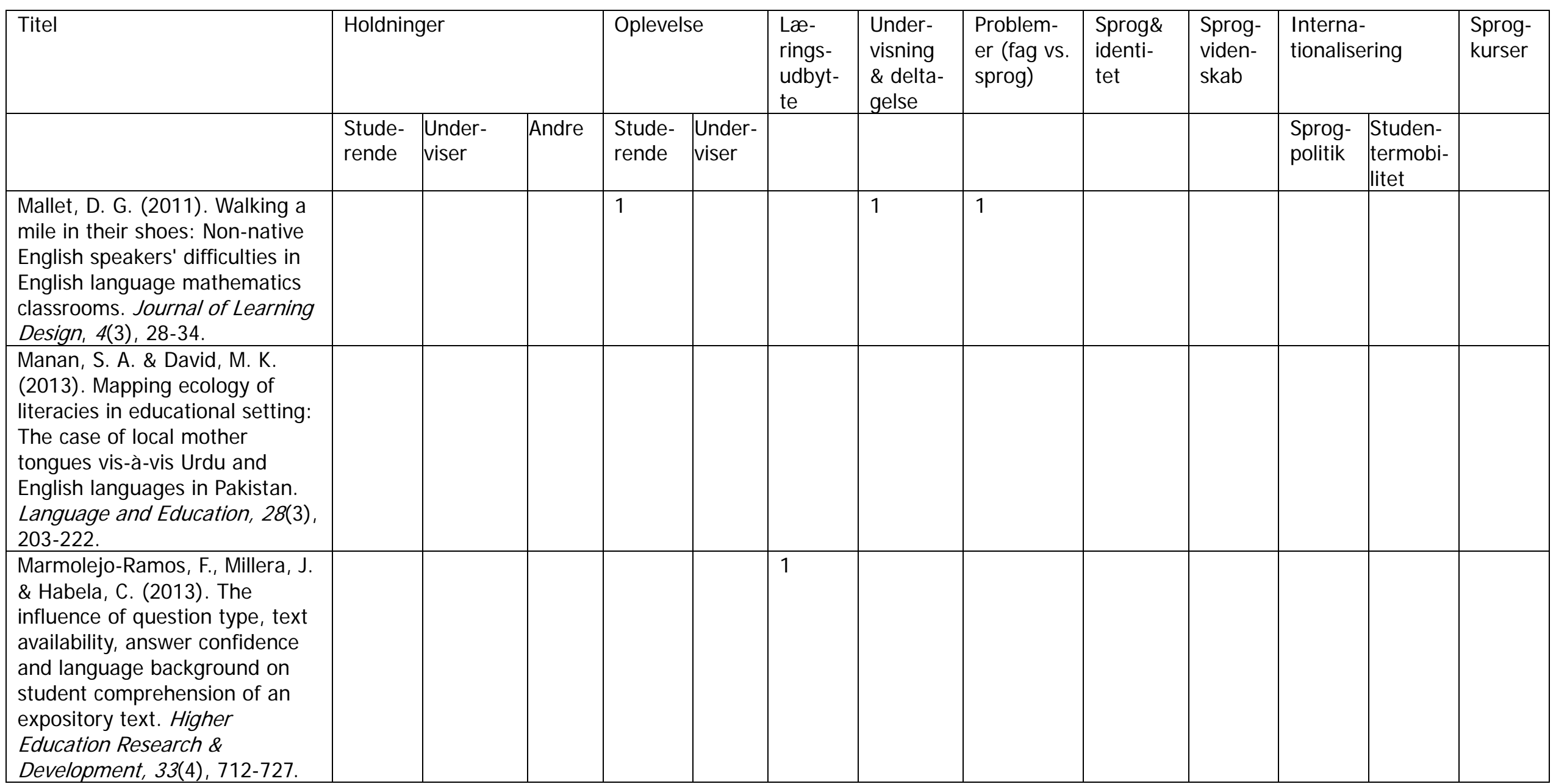




\begin{tabular}{|c|c|c|c|c|c|c|c|c|c|c|c|c|c|}
\hline Titel & Holdnin & ger & & Oplevel & & $\begin{array}{l}\text { Læ- } \\
\text { rings- }\end{array}$ & $\begin{array}{l}\text { Under- } \\
\text { visning }\end{array}$ & $\begin{array}{l}\text { Problem- } \\
\text { er (fag vs. }\end{array}$ & $\begin{array}{l}\text { Sprog\& } \\
\text { identi- }\end{array}$ & $\begin{array}{l}\text { Sprog- } \\
\text { viden- }\end{array}$ & $\begin{array}{l}\text { Interna } \\
\text { tionalis }\end{array}$ & ering & $\begin{array}{l}\text { Sprog- } \\
\text { kurser }\end{array}$ \\
\hline & $\begin{array}{l}\text { Stude- } \\
\text { rende }\end{array}$ & $\begin{array}{l}\text { Under- } \\
\text { viser }\end{array}$ & Andre & $\begin{array}{l}\text { Stude- } \\
\text { rende }\end{array}$ & $\begin{array}{l}\text { Under- } \\
\text { viser }\end{array}$ & & & & & & $\begin{array}{l}\text { Sprog- } \\
\text { politik }\end{array}$ & $\begin{array}{l}\text { Studen- } \\
\text { termobi- } \\
\text { litet }\end{array}$ & \\
\hline $\begin{array}{l}\text { Marriott, H. (2013). } \\
\text { Multilingualism among } \\
\text { university staff: A case study of } \\
\text { language management at an } \\
\text { Australian university. } \\
\text { International Journal of } \\
\text { Multilingualism, 1a4), 454-468. }\end{array}$ & & & & & & & & & & 1 & & & \\
\hline $\begin{array}{l}\text { Martin, P. (2010). "They have } \\
\text { lost their identity but not gained } \\
\text { a British one": Non-traditional } \\
\text { multilingual students in higher } \\
\text { education in the United } \\
\text { Kingdom. Language and } \\
\text { Education, 24(1), 9-20. }\end{array}$ & & & & & & & & & 1 & & & & \\
\hline $\begin{array}{l}\text { Mathews, J. (2007). Predicting } \\
\text { international students' academic } \\
\text { success... may not always be } \\
\text { enough: Assessing Turkey's } \\
\text { foreign study scholarship } \\
\text { program. Higher Education, } \\
53(5), 645-673 \text {. }\end{array}$ & & & & & & & & 1 & & & & 1 & \\
\hline
\end{tabular}




\begin{tabular}{|c|c|c|c|c|c|c|c|c|c|c|c|c|c|}
\hline \multirow[t]{2}{*}{ Titel } & \multicolumn{3}{|c|}{ Holdninger } & \multicolumn{2}{|c|}{ Oplevelse } & \multirow{2}{*}{$\begin{array}{l}\text { Læ- } \\
\text { rings- } \\
\text { udbyt- } \\
\text { te }\end{array}$} & \multirow{2}{*}{$\begin{array}{l}\text { Under- } \\
\text { visning } \\
\& \text { delta- } \\
\text { gelse }\end{array}$} & \multirow{2}{*}{$\begin{array}{l}\text { Problem- } \\
\text { er (fag vs. } \\
\text { sprog) }\end{array}$} & \multirow{2}{*}{$\begin{array}{l}\text { Sprog\& } \\
\text { identi- } \\
\text { tet }\end{array}$} & \multirow{2}{*}{$\begin{array}{l}\text { Sprog- } \\
\text { viden- } \\
\text { skab }\end{array}$} & \multicolumn{2}{|c|}{$\begin{array}{l}\text { Interna- } \\
\text { tionalisering }\end{array}$} & \multirow[t]{2}{*}{$\begin{array}{l}\text { Sprog- } \\
\text { kurser }\end{array}$} \\
\hline & $\begin{array}{l}\text { Stude- } \\
\text { rende }\end{array}$ & $\begin{array}{l}\text { Under- } \\
\text { viser }\end{array}$ & Andre & $\begin{array}{l}\text { Stude- } \\
\text { rende }\end{array}$ & $\begin{array}{l}\text { Under- } \\
\text { viser }\end{array}$ & & & & & & $\begin{array}{l}\text { Sprog- } \\
\text { politik }\end{array}$ & $\begin{array}{l}\text { Studen- } \\
\text { termobi- } \\
\text { litet }\end{array}$ & \\
\hline $\begin{array}{l}\text { Matsuoka, R., Matsumoto, K., } \\
\text { Poole, G. \& Matsuoka, M. } \\
\text { (2014). J apanese university } \\
\text { students' willingness to } \\
\text { communicate in English: The } \\
\text { serendipitous effect of oral } \\
\text { presentations. Journal of Pan- } \\
\text { Pacific Association of Applied } \\
\text { Linguistics, 18(1), 193-218. }\end{array}$ & & & & & & & 1 & & & & & & \\
\hline $\begin{array}{l}\text { Mauranen, A., Hynninen, N. \& } \\
\text { Ranta, E. (2010): English as an } \\
\text { academic lingua franca: The } \\
\text { ELFA project. English for } \\
\text { Specific Purposes, 29(3), 183- } \\
190 .\end{array}$ & & & & 1 & 1 & & & & & 1 & & & \\
\hline $\begin{array}{l}\text { Mazak, C. M. \& Herbas- } \\
\text { Donoso, C. (2014). } \\
\text { Translanguaging practices and } \\
\text { language ideologies in Puerto } \\
\text { Rican university science } \\
\text { education. Critical Inquiry in } \\
\text { Language Studies, 11(1), 27-49. }\end{array}$ & & 1 & & & & & & & & 1 & & & \\
\hline
\end{tabular}




\begin{tabular}{|c|c|c|c|c|c|c|c|c|c|c|c|c|c|}
\hline \multirow[t]{2}{*}{ Titel } & \multicolumn{3}{|c|}{ Holdninger } & \multicolumn{2}{|c|}{ Oplevelse } & \multirow{2}{*}{$\begin{array}{l}\text { Læ- } \\
\text { rings- } \\
\text { udbyt- } \\
\text { te }\end{array}$} & \multirow{2}{*}{$\begin{array}{l}\text { Under- } \\
\text { visning } \\
\& \text { delta- } \\
\text { gelse }\end{array}$} & \multirow{2}{*}{$\begin{array}{l}\text { Problem- } \\
\text { er (fag vs. } \\
\text { sprog) }\end{array}$} & \multirow{2}{*}{$\begin{array}{l}\text { Sprog\& } \\
\text { identi- } \\
\text { tet }\end{array}$} & \multirow{2}{*}{$\begin{array}{l}\text { Sprog- } \\
\text { viden- } \\
\text { skab }\end{array}$} & \multicolumn{2}{|c|}{$\begin{array}{l}\text { Interna- } \\
\text { tionalisering }\end{array}$} & \multirow[t]{2}{*}{$\begin{array}{l}\text { Sprog- } \\
\text { kurser }\end{array}$} \\
\hline & $\begin{array}{l}\text { Stude- } \\
\text { rende }\end{array}$ & $\begin{array}{l}\text { Under- } \\
\text { viser }\end{array}$ & Andre & $\begin{array}{l}\text { Stude- } \\
\text { rende }\end{array}$ & $\begin{array}{l}\text { Under- } \\
\text { viser }\end{array}$ & & & & & & $\begin{array}{l}\text { Sprog- } \\
\text { politik }\end{array}$ & $\begin{array}{l}\text { Studen- } \\
\text { termobi- } \\
\text { litet }\end{array}$ & \\
\hline $\begin{array}{l}\text { Miller, L. (2007). Issues in } \\
\text { lecturing in a second language: } \\
\text { Lecturer's behaviour and } \\
\text { students' perceptions, Studies in } \\
\text { Higher Education, 32(6), 747- } \\
760 .\end{array}$ & & & & & & & & 1 & & & & & \\
\hline $\begin{array}{l}\text { Morell, T. (2007). What } \\
\text { enhances EFL students' } \\
\text { participation in lecture } \\
\text { discourse? Student, lecturer and } \\
\text { discourse perspectives. Journal } \\
\text { of English for Academic } \\
\text { Purposes, } 63 \text { (3), 222-237.. }\end{array}$ & & & & & & & 1 & & & & & & \\
\hline $\begin{array}{l}\text { Murray, N. (2012). Ten "good } \\
\text { practice principles" ...Ten key } \\
\text { questions: Considerations in } \\
\text { addressing the English language } \\
\text { needs of higher education } \\
\text { students. Higher Education } \\
\text { Research and Development, } \\
\text { 31(2). 233-246. }\end{array}$ & & & & & & & & & & & & 1 & \\
\hline
\end{tabular}




\begin{tabular}{|c|c|c|c|c|c|c|c|c|c|c|c|c|c|}
\hline Titel & Holdnin & ger & & Oplevels & & $\begin{array}{l}\text { Læ- } \\
\text { rings- }\end{array}$ & $\begin{array}{l}\text { Under- } \\
\text { visning }\end{array}$ & $\begin{array}{l}\text { Problem- } \\
\text { er (fag vs. }\end{array}$ & $\begin{array}{l}\text { Sprog\& } \\
\text { identi- }\end{array}$ & $\begin{array}{l}\text { Sprog- } \\
\text { viden- }\end{array}$ & $\begin{array}{l}\text { Interna- } \\
\text { tionalise }\end{array}$ & ering & $\begin{array}{l}\text { Sprog- } \\
\text { kurser }\end{array}$ \\
\hline & $\begin{array}{l}\text { Stude- } \\
\text { rende }\end{array}$ & $\begin{array}{l}\text { Under- } \\
\text { viser }\end{array}$ & Andre & $\begin{array}{l}\text { Stude- } \\
\text { rende }\end{array}$ & $\begin{array}{l}\text { Under- } \\
\text { viser }\end{array}$ & & & & & & $\begin{array}{l}\text { Sprog- } \\
\text { politik }\end{array}$ & $\begin{array}{l}\text { Studen- } \\
\text { termobi- } \\
\text { litet }\end{array}$ & \\
\hline $\begin{array}{l}\text { Murray, N. (2013). Widening } \\
\text { participation and English } \\
\text { language proficiency: A } \\
\text { convergence with implications } \\
\text { for assessment practices in } \\
\text { higher education. Studies in } \\
\text { Higher Education, 38(2), 299- } \\
\text { 311. }\end{array}$ & & & & & & & & 1 & & & & & \\
\hline $\begin{array}{l}\text { Nevile-Barton, P. \& Barton, B. } \\
\text { (2005). The relationship } \\
\text { between English language and } \\
\text { mathematics learning for non- } \\
\text { native speakers. Wellington: } \\
\text { Teaching and Learning Research } \\
\text { Initiative. }\end{array}$ & & & & & & 1 & & & & & & & \\
\hline $\begin{array}{l}\text { Ngcobo, S. (2014). The struggle } \\
\text { to maintain identity in higher } \\
\text { education among Zulu-speaking } \\
\text { students. International Journal } \\
\text { of Bilingual Education and } \\
\text { Bilingualism, 176), 695-713. }\end{array}$ & & & & & & & & 1 & 1 & & & & \\
\hline $\begin{array}{l}\text { Oliver, R., Vanderford, S. \& } \\
\text { Grote, E. (2012). Evidence of } \\
\text { English language proficiency } \\
\text { and academic achievement of } \\
\text { non-English-speaking } \\
\text { background students. Higher } \\
\text { Education Research and } \\
\text { Development, 31(4), 541-555. }\end{array}$ & & & & & & & & 1 & & & & 1 & \\
\hline
\end{tabular}




\begin{tabular}{|c|c|c|c|c|c|c|c|c|c|c|c|c|c|}
\hline Titel & Holdnin & gger & & Opleve & & $\begin{array}{l}\text { Læ- } \\
\text { rings- }\end{array}$ & $\begin{array}{l}\text { Under- } \\
\text { visning }\end{array}$ & $\begin{array}{l}\text { Problem- } \\
\text { er (fag vs. }\end{array}$ & $\begin{array}{l}\text { Sprog\& } \\
\text { identi- }\end{array}$ & $\begin{array}{l}\text { Sprog- } \\
\text { viden- }\end{array}$ & $\begin{array}{l}\text { Interna } \\
\text { tionalis }\end{array}$ & ering & $\begin{array}{l}\text { Sprog- } \\
\text { kurser }\end{array}$ \\
\hline & $\begin{array}{l}\text { Stude- } \\
\text { rende }\end{array}$ & $\begin{array}{l}\text { Under- } \\
\text { viser }\end{array}$ & Andre & $\begin{array}{l}\text { Stude- } \\
\text { rende }\end{array}$ & $\begin{array}{l}\text { Under- } \\
\text { viser }\end{array}$ & & & & & & $\begin{array}{l}\text { Sprog- } \\
\text { politik }\end{array}$ & $\begin{array}{l}\text { Studen- } \\
\text { termobi- } \\
\text { litet }\end{array}$ & \\
\hline $\begin{array}{l}\text { Onsman, A. (2013). } \\
\text { International students at } \\
\text { Chinese joint venture } \\
\text { universities: Factors influencing } \\
\text { decisions to enrol. Australian } \\
\text { Universities' Review, } 55(2), 15- \\
23 \text {. }\end{array}$ & & & & & & & & & & & & 1 & \\
\hline $\begin{array}{l}\text { Parkinson, J. \& Crouch, A. } \\
\text { (2011). Education, language, } \\
\text { and identity amongst students } \\
\text { at a South African university. } \\
\text { Journal of Language, /dentity, } \\
\text { and Education, } 10(2), 83-98 .\end{array}$ & 1 & & & & & & & 1 & & & & & \\
\hline $\begin{array}{l}\text { Paxton, M. I. J. (2009). "It's } \\
\text { easy to learn when you using } \\
\text { your home language but with } \\
\text { English you need to start } \\
\text { learning language before you } \\
\text { get to the concept": Bilingual } \\
\text { concept development in an } \\
\text { English-medium university in } \\
\text { South Africa. Journal of } \\
\text { Multilingual and Multicultural } \\
\text { Development, 304), 345-359. }\end{array}$ & & & & & & 1 & & & & & & & \\
\hline
\end{tabular}




\begin{tabular}{|c|c|c|c|c|c|c|c|c|c|c|c|c|c|}
\hline Titel & Holdnin & ger & & Oplevel & & $\begin{array}{l}\text { Læ- } \\
\text { rings- }\end{array}$ & $\begin{array}{l}\text { Under- } \\
\text { visning }\end{array}$ & $\begin{array}{l}\text { Problem- } \\
\text { er (fag vs. }\end{array}$ & $\begin{array}{l}\text { Sprog\& } \\
\text { identi- }\end{array}$ & $\begin{array}{l}\text { Sprog- } \\
\text { viden- }\end{array}$ & $\begin{array}{l}\text { Interna } \\
\text { tionalis }\end{array}$ & ering & $\begin{array}{l}\text { Sprog- } \\
\text { kurser }\end{array}$ \\
\hline & $\begin{array}{l}\text { Stude- } \\
\text { rende }\end{array}$ & $\begin{array}{l}\text { Under- } \\
\text { viser }\end{array}$ & Andre & $\begin{array}{l}\text { Stude- } \\
\text { rende }\end{array}$ & $\begin{array}{l}\text { Under- } \\
\text { viser }\end{array}$ & & & & & & $\begin{array}{l}\text { Sprog- } \\
\text { politik }\end{array}$ & $\begin{array}{l}\text { Studen- } \\
\text { termobi- } \\
\text { litet }\end{array}$ & \\
\hline $\begin{array}{l}\text { Preece, S. (2010). Multilingual } \\
\text { identities in higher education: } \\
\text { Negotiating the "mother } \\
\text { tongue", "posh" and "slang". } \\
\text { Language and Education, 24(1), } \\
\text { 21-39. }\end{array}$ & & & & & & & & & 1 & & & & \\
\hline $\begin{array}{l}\text { Pretorius, E. J. (2006). The } \\
\text { comprehension of logical } \\
\text { relations in expository texts by } \\
\text { students who study through the } \\
\text { medium of ESL. System: An } \\
\text { International Journal of } \\
\text { Educational Technology and } \\
\text { Applied Linguistics, 34(3), 432- } \\
450 .\end{array}$ & & & & & & 1 & & 1 & & & & & \\
\hline $\begin{array}{l}\text { Ramburuth, P. (2001). } \\
\text { Language diversity and the first- } \\
\text { year experience: Implications } \\
\text { for academic achievement and } \\
\text { language skills acquisition. } \\
\text { Journal of the First-Year } \\
\text { Experience \& Students in } \\
\text { Transition, 13(2),75-94.. }\end{array}$ & & & & & & 1 & & 1 & & & & & \\
\hline
\end{tabular}




\begin{tabular}{|c|c|c|c|c|c|c|c|c|c|c|c|c|c|}
\hline Titel & Holdnir & & & Oplevel & & $\begin{array}{l}\text { Læ- } \\
\text { rings- }\end{array}$ & $\begin{array}{l}\text { Under- } \\
\text { visning }\end{array}$ & $\begin{array}{l}\text { Problem- } \\
\text { er (fag vs. }\end{array}$ & $\begin{array}{l}\text { Sprog\& } \\
\text { identi- }\end{array}$ & $\begin{array}{l}\text { Sprog- } \\
\text { viden- }\end{array}$ & $\begin{array}{l}\text { Interna } \\
\text { tionalis }\end{array}$ & ering & $\begin{array}{l}\text { Sprog- } \\
\text { kurser }\end{array}$ \\
\hline & $\begin{array}{l}\text { Stude- } \\
\text { rende }\end{array}$ & $\begin{array}{l}\text { Under- } \\
\text { viser }\end{array}$ & Andre & $\begin{array}{l}\text { Stude- } \\
\text { rende }\end{array}$ & $\begin{array}{l}\text { Under- } \\
\text { viser }\end{array}$ & & & & & & $\begin{array}{l}\text { Sprog- } \\
\text { politik }\end{array}$ & $\begin{array}{l}\text { Studen- } \\
\text { termobi- } \\
\text { litet }\end{array}$ & \\
\hline $\begin{array}{l}\text { Ramsay, S., Barker, M. \& J ones, } \\
\text { E. (1999): Academic adjustment } \\
\text { and learning processes: A } \\
\text { comparison of international and } \\
\text { local students in first-year } \\
\text { university. Higher Education } \\
\text { Research \& Development 1\&(1), } \\
\text { 129-144. }\end{array}$ & & & & 1 & & & & & & & & & \\
\hline $\begin{array}{l}\text { Rees, J. \& Klapper, J. (2007). } \\
\text { Analysing and evaluating the } \\
\text { linguistic benefit of residence } \\
\text { abroad for UK foreign language } \\
\text { students. Assesment \& } \\
\text { Evaluation in Higher Education } \\
\text { 32(3), 331-353. }\end{array}$ & & & & & & & & & & & & 1 & \\
\hline $\begin{array}{l}\text { Rienties, B., Luchoomun, D. \& } \\
\text { Tempelaar, D. (2014). Academic } \\
\text { and social integration of master } \\
\text { students: A cross-institutional } \\
\text { comparison between Dutch and } \\
\text { international students. } \\
\text { Innovations in Education and } \\
\text { Teaching International, 51(2), } \\
\text { 130-141. }\end{array}$ & & & & & & 1 & & & & & & 1 & \\
\hline
\end{tabular}




\begin{tabular}{|c|c|c|c|c|c|c|c|c|c|c|c|c|c|}
\hline \multirow[t]{2}{*}{ Titel } & \multicolumn{3}{|c|}{ Holdninger } & \multicolumn{2}{|c|}{ Oplevelse } & \multirow{2}{*}{$\begin{array}{l}\text { Læ- } \\
\text { rings- } \\
\text { udbyt- } \\
\text { te }\end{array}$} & \multirow{2}{*}{$\begin{array}{l}\text { Under- } \\
\text { visning } \\
\& \text { delta- } \\
\text { gelse }\end{array}$} & \multirow{2}{*}{$\begin{array}{l}\text { Problem- } \\
\text { er (fag vs. } \\
\text { sprog) }\end{array}$} & \multirow{2}{*}{$\begin{array}{l}\text { Sprog\& } \\
\text { identi- } \\
\text { tet }\end{array}$} & \multirow{2}{*}{$\begin{array}{l}\text { Sprog- } \\
\text { viden- } \\
\text { skab }\end{array}$} & \multicolumn{2}{|c|}{$\begin{array}{l}\text { Interna- } \\
\text { tionalisering }\end{array}$} & \multirow[t]{2}{*}{$\begin{array}{l}\text { Sprog- } \\
\text { kurser }\end{array}$} \\
\hline & $\begin{array}{l}\text { Stude- } \\
\text { rende }\end{array}$ & $\begin{array}{l}\text { Under- } \\
\text { viser }\end{array}$ & Andre & $\begin{array}{l}\text { Stude- } \\
\text { rende }\end{array}$ & $\begin{array}{l}\text { Under- } \\
\text { viser }\end{array}$ & & & & & & $\begin{array}{l}\text { Sprog- } \\
\text { politik }\end{array}$ & $\begin{array}{l}\text { Studen- } \\
\text { termobi- } \\
\text { litet }\end{array}$ & \\
\hline $\begin{array}{l}\text { Saarinen, T. (2012). } \\
\text { Internationalization of Finnish } \\
\text { higher education - is language } \\
\text { an issue? International Journal } \\
\text { of the Sociology of Language, } \\
216,157-173 .\end{array}$ & & & & & & & & & & & 1 & & \\
\hline $\begin{array}{l}\text { Sakurai, Y. (2009). Academic } \\
\text { experiences in a cross-national } \\
\text { tertiary program: Language } \\
\text { immersion amid the sciences. } \\
\text { International Journal of } \\
\text { Teaching and Learning in Higher } \\
\text { Education, 21(2), 239-248. }\end{array}$ & & & & 1 & & & & 1 & & & & 1 & \\
\hline
\end{tabular}




\begin{tabular}{|c|c|c|c|c|c|c|c|c|c|c|c|c|c|}
\hline Titel & Holdnin & iger & & Oplevel & & $\begin{array}{l}\text { Læ- } \\
\text { rings- }\end{array}$ & $\begin{array}{l}\text { Under- } \\
\text { visning }\end{array}$ & $\begin{array}{l}\text { Problem- } \\
\text { er (fag vs. }\end{array}$ & $\begin{array}{l}\text { Sprog\& } \\
\text { identi- }\end{array}$ & $\begin{array}{l}\text { Sprog- } \\
\text { viden- }\end{array}$ & $\begin{array}{l}\text { Interna } \\
\text { tionalis }\end{array}$ & ering & $\begin{array}{l}\text { Sprog- } \\
\text { kurser }\end{array}$ \\
\hline & $\begin{array}{l}\text { Stude- } \\
\text { rende }\end{array}$ & $\begin{array}{l}\text { Under- } \\
\text { viser }\end{array}$ & Andre & $\begin{array}{l}\text { Stude- } \\
\text { rende }\end{array}$ & $\begin{array}{l}\text { Under- } \\
\text { viser }\end{array}$ & & & & & & $\begin{array}{l}\text { Sprog- } \\
\text { politik }\end{array}$ & $\begin{array}{l}\text { Studen- } \\
\text { termobi- } \\
\text { litet }\end{array}$ & \\
\hline $\begin{array}{l}\text { Sasayama, S. (2013). Japanese } \\
\text { college students' attitudes } \\
\text { towards J apan English and } \\
\text { American English. Journal of } \\
\text { Multilingual and Multicultural } \\
\text { Development, 34(3), 264-278. }\end{array}$ & 1 & & & & & & & & & & & & \\
\hline $\begin{array}{l}\text { Schoerning, E. (2014). The } \\
\text { effect of plain-English } \\
\text { vocabulary on student } \\
\text { achievement and classroom } \\
\text { culture in college science } \\
\text { instruction. International } \\
\text { Journal of Science and } \\
\text { Mathematics Education, 12(2), } \\
\text { 307-327. }\end{array}$ & & & & & & 1 & & & & & & & 1 \\
\hline $\begin{array}{l}\text { Skyrme, G. (2007). Entering the } \\
\text { university: the differentiated } \\
\text { experience of two Chinese } \\
\text { international students in a New } \\
\text { Zealand university. Studies in } \\
\text { Higher Education, 32(3), 357- } \\
\text { 372. }\end{array}$ & & & & 1 & & & & & & & & 1 & \\
\hline
\end{tabular}




\begin{tabular}{|c|c|c|c|c|c|c|c|c|c|c|c|c|c|}
\hline \multirow[t]{2}{*}{ Titel } & \multicolumn{3}{|c|}{ Holdninger } & \multicolumn{2}{|c|}{ Oplevelse } & \multirow{2}{*}{$\begin{array}{l}\text { Læ- } \\
\text { rings- } \\
\text { udbyt- } \\
\text { te }\end{array}$} & \multirow{2}{*}{$\begin{array}{l}\text { Under- } \\
\text { visning } \\
\text { \& delta- } \\
\text { gelse }\end{array}$} & \multirow{2}{*}{$\begin{array}{l}\text { Problem- } \\
\text { er (fag vs. } \\
\text { sprog) }\end{array}$} & \multirow{2}{*}{$\begin{array}{l}\text { Sprog\& } \\
\text { identi- } \\
\text { tet }\end{array}$} & \multirow{2}{*}{$\begin{array}{l}\text { Sprog- } \\
\text { viden- } \\
\text { skab }\end{array}$} & \multicolumn{2}{|c|}{$\begin{array}{l}\text { Interna- } \\
\text { tionalisering }\end{array}$} & \multirow[t]{2}{*}{$\begin{array}{l}\text { Sprog- } \\
\text { kurser }\end{array}$} \\
\hline & $\begin{array}{l}\text { Stude- } \\
\text { rende }\end{array}$ & $\begin{array}{l}\text { Under- } \\
\text { viser }\end{array}$ & Andre & $\begin{array}{l}\text { Stude- } \\
\text { rende }\end{array}$ & $\begin{array}{l}\text { Under- } \\
\text { viser }\end{array}$ & & & & & & $\begin{array}{l}\text { Sprog- } \\
\text { politik }\end{array}$ & $\begin{array}{l}\text { Studen- } \\
\text { termobi- } \\
\text { litet }\end{array}$ & \\
\hline $\begin{array}{l}\text { Soontiens, W. (2004). When in } \\
\text { Rome: The realities of skill } \\
\text { development in an "anglo" } \\
\text { educational environment. } \\
\text { Journal of Research in } \\
\text { International Education, 3(3), } \\
\text { 301-317. }\end{array}$ & & & & & & & & & & & & 1 & \\
\hline $\begin{array}{l}\text { Starfield, S. (2001). "I'm a } \\
\text { second-Language English } \\
\text { speaker": Negotiating writer } \\
\text { identity and authority in } \\
\text { sociology one. Journal of } \\
\text { Language, Identity and } \\
\text { Education 1(2), 121-140. }\end{array}$ & & & & & & & & & 1 & & & & \\
\hline $\begin{array}{l}\text { Sterzuk, A. (2015). "The } \\
\text { standard remains the same": } \\
\text { Language standardization, race } \\
\text { and othering in higher } \\
\text { education. Journal of } \\
\text { Multilingual and Multicultural } \\
\text { Development, 361), 53-66. }\end{array}$ & & 1 & & & & & & & & & 1 & & \\
\hline
\end{tabular}




\begin{tabular}{|c|c|c|c|c|c|c|c|c|c|c|c|c|c|}
\hline \multirow[t]{2}{*}{ Titel } & \multicolumn{3}{|c|}{ Holdninger } & \multicolumn{2}{|c|}{ Oplevelse } & \multirow{2}{*}{$\begin{array}{l}\text { Læ- } \\
\text { rings- } \\
\text { udbyt- } \\
\text { te }\end{array}$} & \multirow{2}{*}{$\begin{array}{l}\text { Under- } \\
\text { visning } \\
\& \text { delta- } \\
\text { gelse }\end{array}$} & \multirow{2}{*}{$\begin{array}{l}\text { Problem- } \\
\text { er (fag vs. } \\
\text { sprog) }\end{array}$} & \multirow{2}{*}{$\begin{array}{l}\text { Sprog\& } \\
\text { identi- } \\
\text { tet }\end{array}$} & \multirow{2}{*}{$\begin{array}{l}\text { Sprog- } \\
\text { viden- } \\
\text { skab }\end{array}$} & \multicolumn{2}{|c|}{$\begin{array}{l}\text { Interna- } \\
\text { tionalisering }\end{array}$} & \multirow[t]{2}{*}{$\begin{array}{l}\text { Sprog- } \\
\text { kurser }\end{array}$} \\
\hline & $\begin{array}{l}\text { Stude- } \\
\text { rende }\end{array}$ & $\begin{array}{l}\text { Under- } \\
\text { viser }\end{array}$ & Andre & $\begin{array}{l}\text { Stude-- } \\
\text { rende }\end{array}$ & $\begin{array}{l}\text { Under- } \\
\text { viser }\end{array}$ & & & & & & $\begin{array}{l}\text { Sprog- } \\
\text { politik }\end{array}$ & $\begin{array}{l}\text { Studen- } \\
\text { termobi- } \\
\text { litet }\end{array}$ & \\
\hline $\begin{array}{l}\text { Stoynoff, S. (1997). Factors } \\
\text { associated with international } \\
\text { students' academic } \\
\text { achievement. Journal of } \\
\text { Instructional Psychology, 24(1), } \\
\text { 56-68. }\end{array}$ & & & & & & 1 & & & & & & 1 & \\
\hline $\begin{array}{l}\text { Summers, M. \& Voleta, S. } \\
\text { (2008). Students' attitudes } \\
\text { towards culturally mixed groups } \\
\text { on international campuses: } \\
\text { impact of participation in } \\
\text { diverse and non-diverse groups. } \\
\text { Studies in Higher Education, } \\
\text { 33(4), 357-370. }\end{array}$ & 1 & & & 1 & & & & & & & & 1 & \\
\hline $\begin{array}{l}\text { Tarnopolsky, O. B. \& Goodman, } \\
\text { B. A. (2014). The ecology of } \\
\text { language in classrooms at a } \\
\text { university in eastern Ukraine. } \\
\text { Language and Education, 28(4), } \\
\text { 383-396. }\end{array}$ & 1 & 1 & & & & & & & & & & & \\
\hline
\end{tabular}




\begin{tabular}{|c|c|c|c|c|c|c|c|c|c|c|c|c|c|}
\hline \multirow[t]{2}{*}{ Titel } & \multicolumn{3}{|c|}{ Holdninger } & \multicolumn{2}{|c|}{ Oplevelse } & \multirow{2}{*}{$\begin{array}{l}\text { Læ- } \\
\text { rings- } \\
\text { udbyt- } \\
\text { te }\end{array}$} & \multirow{2}{*}{$\begin{array}{l}\text { Under- } \\
\text { visning } \\
\& \text { delta- } \\
\text { gelse }\end{array}$} & \multirow{2}{*}{$\begin{array}{l}\text { Problem- } \\
\text { er (fag vs. } \\
\text { sprog) }\end{array}$} & \multirow{2}{*}{$\begin{array}{l}\text { Sprog\& } \\
\text { identi- } \\
\text { tet }\end{array}$} & \multirow{2}{*}{$\begin{array}{l}\text { Sprog- } \\
\text { viden- } \\
\text { skab }\end{array}$} & \multicolumn{2}{|c|}{$\begin{array}{l}\text { Interna- } \\
\text { tionalisering }\end{array}$} & \multirow[t]{2}{*}{$\begin{array}{l}\text { Sprog- } \\
\text { kurser }\end{array}$} \\
\hline & $\begin{array}{l}\text { Stude- } \\
\text { rende }\end{array}$ & $\begin{array}{l}\text { Under- } \\
\text { viser }\end{array}$ & Andre & $\begin{array}{l}\text { Stude- } \\
\text { rende }\end{array}$ & $\begin{array}{l}\text { Under- } \\
\text { viser }\end{array}$ & & & & & & $\begin{array}{l}\text { Sprog- } \\
\text { politik }\end{array}$ & $\begin{array}{l}\text { Studen- } \\
\text { termobi- } \\
\text { litet }\end{array}$ & \\
\hline $\begin{array}{l}\text { Tatzl, D. (2011). English- } \\
\text { medium masters' programmes } \\
\text { at an Austrian university of } \\
\text { applied sciences: Attitudes, } \\
\text { experiences and challenges. } \\
\text { Journal of English for Academic } \\
\text { Purposes, 104), } 252-270 .\end{array}$ & 1 & 1 & 1 & 1 & 1 & & & & & & & & \\
\hline $\begin{array}{l}\text { Toh, G. (2013). Where realities } \\
\text { confront ideals: The personal, } \\
\text { professional, philosophical and } \\
\text { political in the teaching of } \\
\text { academic English in a Japanese } \\
\text { setting. Policy Futures in } \\
\text { Education, 11(5), 589-605. }\end{array}$ & & & 1 & & & & & & & & 1 & & \\
\hline $\begin{array}{l}\text { Tong, F. \& Shi, Q. (2012). } \\
\text { Chinese-English bilingual } \\
\text { education in China: A case } \\
\text { study of college science majors. } \\
\text { International Journal of } \\
\text { Bilingual Education and } \\
\text { Bilingualism, 15(2), 165-182. }\end{array}$ & 1 & & & & & & & & & & & & \\
\hline
\end{tabular}




\begin{tabular}{|c|c|c|c|c|c|c|c|c|c|c|c|c|c|}
\hline \multirow[t]{2}{*}{ Titel } & \multicolumn{3}{|c|}{ Holdninger } & \multicolumn{2}{|c|}{ Oplevelse } & \multirow{2}{*}{$\begin{array}{l}\text { Læ- } \\
\text { rings- } \\
\text { udbyt- } \\
\text { te }\end{array}$} & \multirow{2}{*}{$\begin{array}{l}\text { Under- } \\
\text { visning } \\
\& \text { delta- } \\
\text { gelse }\end{array}$} & \multirow{2}{*}{$\begin{array}{l}\text { Problem- } \\
\text { er (fag vs. } \\
\text { sprog) }\end{array}$} & \multirow{2}{*}{$\begin{array}{l}\text { Sprog\& } \\
\text { identi- } \\
\text { tet }\end{array}$} & \multirow{2}{*}{$\begin{array}{l}\text { Sprog- } \\
\text { viden- } \\
\text { skab }\end{array}$} & \multicolumn{2}{|c|}{$\begin{array}{l}\text { Interna- } \\
\text { tionalisering }\end{array}$} & \multirow[t]{2}{*}{$\begin{array}{l}\text { Sprog- } \\
\text { kurser }\end{array}$} \\
\hline & $\begin{array}{l}\text { Stude- } \\
\text { rende }\end{array}$ & $\begin{array}{l}\text { Under- } \\
\text { viser }\end{array}$ & Andre & $\begin{array}{l}\text { Stude- } \\
\text { rende }\end{array}$ & $\begin{array}{l}\text { Under- } \\
\text { viser }\end{array}$ & & & & & & $\begin{array}{l}\text { Sprog- } \\
\text { politik }\end{array}$ & \begin{tabular}{|l} 
Studen- \\
termobi- \\
litet
\end{tabular} & \\
\hline $\begin{array}{l}\text { Torres-Olave, B. M. (2012). } \\
\text { Imaginative geographies: } \\
\text { I dentity, difference, and English } \\
\text { as the language of instruction in } \\
\text { a Mexican university program. } \\
\text { Higher Education: The } \\
\text { International Journal of Higher } \\
\text { Education and Educational } \\
\text { Planning, 63(3), 317-335. }\end{array}$ & & & & & & & & & 1 & & & & \\
\hline $\begin{array}{l}\text { Trent, J. (2012). The } \\
\text { internationalization of tertiary } \\
\text { education in Asia: Language, } \\
\text { identity, and conflict. Journal of } \\
\text { Research in International } \\
\text { Education, 11(1), 50-69. }\end{array}$ & & & & & & & & & 1 & & & & \\
\hline $\begin{array}{l}\text { Unterberger, B. (2012). English- } \\
\text { medium programmes at } \\
\text { Austrian business faculties: A } \\
\text { status quo survey on national } \\
\text { trends and a case study on } \\
\text { programme design and delivery. } \\
\text { A/LA Review, } 25,80-100 \text {. }\end{array}$ & & & & & & & & & & & 1 & & \\
\hline
\end{tabular}




\begin{tabular}{|c|c|c|c|c|c|c|c|c|c|c|c|c|c|}
\hline Titel & Holdnir & & & Opleve & & $\begin{array}{l}\text { Læ- } \\
\text { rings- }\end{array}$ & $\begin{array}{l}\text { Under- } \\
\text { visning }\end{array}$ & $\begin{array}{l}\text { Problem- } \\
\text { er (fag vs. }\end{array}$ & $\begin{array}{l}\text { Sprog\& } \\
\text { identi- }\end{array}$ & $\begin{array}{l}\text { Sprog- } \\
\text { viden- }\end{array}$ & $\begin{array}{l}\text { Interna } \\
\text { tionalis }\end{array}$ & ering & $\begin{array}{l}\text { Sprog- } \\
\text { kurser }\end{array}$ \\
\hline & $\begin{array}{l}\text { Stude- } \\
\text { rende }\end{array}$ & $\begin{array}{l}\text { Under- } \\
\text { viser }\end{array}$ & Andre & $\begin{array}{l}\text { Stude- } \\
\text { rende }\end{array}$ & $\begin{array}{l}\text { Under- } \\
\text { viser }\end{array}$ & & & & & & $\begin{array}{l}\text { Sprog- } \\
\text { politik }\end{array}$ & $\begin{array}{l}\text { Studen- } \\
\text { termobi- } \\
\text { litet }\end{array}$ & \\
\hline $\begin{array}{l}\text { Vinther, J. \& Slethaug, G. } \\
\text { (2015). The impact of } \\
\text { international students on the } \\
\text { university work environment: A } \\
\text { Comparative study of a } \\
\text { Canadian and a Danish } \\
\text { university. Language and } \\
\text { Intercultural Communication, } \\
\text { 15(1), 92-108. }\end{array}$ & & & & & 1 & & & & & & & 1 & \\
\hline $\begin{array}{l}\text { Watkins, D., Biggs, J. \& Regmi, } \\
\text { M. (1991). Does confidence in } \\
\text { the medium of instruction } \\
\text { influence a student's approach } \\
\text { to learning? Instructional } \\
\text { Science, 2a4), 331-339. }\end{array}$ & & & & & & & 1 & & & & & & \\
\hline $\begin{array}{l}\text { Wilkins, S. \& Urbanovic, J. } \\
\text { (2014). English as the lingua } \\
\text { franca in transnational higher } \\
\text { education: Motives and } \\
\text { prospects of institutions that } \\
\text { teach in languages other than } \\
\text { English. Journal of Studies in } \\
\text { International Education, 18(5), } \\
\text { 405-425. }\end{array}$ & & & & & & & & & & 1 & & & \\
\hline
\end{tabular}




\begin{tabular}{|c|c|c|c|c|c|c|c|c|c|c|c|c|c|}
\hline Titel & Holdning & & & Oplevel & & $\begin{array}{l}\text { Læ- } \\
\text { rings- }\end{array}$ & $\begin{array}{l}\text { Under- } \\
\text { visning }\end{array}$ & $\begin{array}{l}\text { Problem- } \\
\text { er (fag vs. }\end{array}$ & $\begin{array}{l}\text { Sprog\& } \\
\text { identi- }\end{array}$ & $\begin{array}{l}\text { Sprog- } \\
\text { viden- }\end{array}$ & $\begin{array}{l}\text { Interna } \\
\text { tionalis }\end{array}$ & ering & $\begin{array}{l}\text { Sprog- } \\
\text { kurser }\end{array}$ \\
\hline & $\begin{array}{l}\text { Stude- } \\
\text { rende }\end{array}$ & $\begin{array}{l}\text { Under- } \\
\text { viser }\end{array}$ & Andre & $\begin{array}{l}\text { Stude- } \\
\text { rende }\end{array}$ & $\begin{array}{l}\text { Under- } \\
\text { viser }\end{array}$ & & & & & & $\begin{array}{l}\text { Sprog- } \\
\text { politik }\end{array}$ & $\begin{array}{l}\text { Studen- } \\
\text { termobi- } \\
\text { litet }\end{array}$ & \\
\hline $\begin{array}{l}\text { Yang, W. \& Gosling, M. (2014). } \\
\text { What makes a Taiwan CLIL } \\
\text { programme highly } \\
\text { recommended or not } \\
\text { recommended? International } \\
\text { Journal of Bilingual Education } \\
\text { and Bilingualism, 1Л4), 394- } \\
409 .\end{array}$ & 1 & & & 1 & & & 1 & & & & 1 & & \\
\hline $\begin{array}{l}\text { Yanyin, Z. \& Yinan, M. (2010). } \\
\text { Another look at the language } \\
\text { difficulties of international } \\
\text { students. Journal of Studies in } \\
\text { International Education, 14(4), } \\
\text { 371-388. }\end{array}$ & & & & & & & & 1 & & & & 1 & \\
\hline $\begin{array}{l}\text { Yates, L. \& Wahid, R. (2013). } \\
\text { Challenges to brand Australia: } \\
\text { International students and the } \\
\text { problem with speaking. Higher } \\
\text { Education Research and } \\
\text { Development, 32(6), 1037- } \\
\text { 1050. }\end{array}$ & & & & & & & & 1 & & & & 1 & \\
\hline
\end{tabular}




\begin{tabular}{|c|c|c|c|c|c|c|c|c|c|c|c|c|c|}
\hline Titel & Holdnin & & & Oplevel & & $\begin{array}{l}\text { Læ- } \\
\text { rings- }\end{array}$ & $\begin{array}{l}\text { Under- } \\
\text { visning }\end{array}$ & $\begin{array}{l}\text { Problem- } \\
\text { er (fag vs. }\end{array}$ & $\begin{array}{l}\text { Sprog\& } \\
\text { identi- }\end{array}$ & $\begin{array}{l}\text { Sprog- } \\
\text { viden- }\end{array}$ & $\begin{array}{l}\text { Interna } \\
\text { tionalis }\end{array}$ & ering & $\begin{array}{l}\text { Sprog- } \\
\text { kurser }\end{array}$ \\
\hline & $\begin{array}{l}\text { Stude- } \\
\text { rende }\end{array}$ & $\begin{array}{l}\text { Under- } \\
\text { viser }\end{array}$ & Andre & $\begin{array}{l}\text { Stude- } \\
\text { rende }\end{array}$ & $\begin{array}{l}\text { Under- } \\
\text { viser }\end{array}$ & & & & & & $\begin{array}{l}\text { Sprog- } \\
\text { politik }\end{array}$ & $\begin{array}{l}\text { Studen- } \\
\text { termobi- } \\
\text { litet }\end{array}$ & \\
\hline $\begin{array}{l}\text { Yeh, C.-C. (2014). Taiwanese } \\
\text { students' experiences and } \\
\text { attitudes towards English- } \\
\text { medium courses in tertiary } \\
\text { education. RELC J ournal: } A \\
\text { Journal of Language Teaching } \\
\text { and Research, } 45(3), 305-319 .\end{array}$ & 1 & & & 1 & & & & & & & & & \\
\hline $\begin{array}{l}\text { Yushau, B. (2009). Mathematics } \\
\text { and language: Issues among } \\
\text { bilingual Arabs in English } \\
\text { medium universities. } \\
\text { International Journal of } \\
\text { Mathematical Education in } \\
\text { Science and Technology, 4a7), } \\
\text { 915-926. }\end{array}$ & & & & & & & 1 & & & & & & \\
\hline $\begin{array}{l}\text { Zacharias, N. T. (2013). } \\
\text { Navigating through the English- } \\
\text { medium-of-instruction policy: } \\
\text { Voices from the field. Current } \\
\text { Issues in Language Planning, } \\
\text { 14(1), 93-108. }\end{array}$ & 1 & 1 & & & & & & & & & 1 & & \\
\hline
\end{tabular}




\begin{tabular}{|c|c|c|c|c|c|c|c|c|c|c|c|c|c|}
\hline \multirow[t]{2}{*}{ Titel } & \multicolumn{3}{|c|}{ Holdninger } & \multicolumn{2}{|c|}{ Oplevelse } & \multirow{2}{*}{$\begin{array}{l}\text { Læ- } \\
\text { rings- } \\
\text { udbyt- } \\
\text { te }\end{array}$} & \multirow{2}{*}{$\begin{array}{l}\text { Under- } \\
\text { visning } \\
\& \text { delta- } \\
\text { gelse }\end{array}$} & \multirow{2}{*}{$\begin{array}{l}\text { Problem- } \\
\text { er (fag vs. } \\
\text { sprog) }\end{array}$} & \multirow{2}{*}{$\begin{array}{l}\text { Sprog\& } \\
\text { identi- } \\
\text { tet }\end{array}$} & \multirow{2}{*}{$\begin{array}{l}\text { Sprog- } \\
\text { viden- } \\
\text { skab }\end{array}$} & \multicolumn{2}{|c|}{$\begin{array}{l}\text { Interna- } \\
\text { tionalisering }\end{array}$} & \multirow[t]{2}{*}{$\begin{array}{l}\text { Sprog- } \\
\text { kurser }\end{array}$} \\
\hline & $\begin{array}{l}\text { Stude- } \\
\text { rende }\end{array}$ & $\begin{array}{l}\text { Under- } \\
\text { viser }\end{array}$ & Andre & $\begin{array}{l}\text { Stude- } \\
\text { rende }\end{array}$ & $\begin{array}{l}\text { Under- } \\
\text { viser }\end{array}$ & & & & & & $\begin{array}{l}\text { Sprog- } \\
\text { politik }\end{array}$ & $\begin{array}{l}\text { Studen- } \\
\text { termobi- } \\
\text { litet }\end{array}$ & \\
\hline $\begin{array}{l}\text { Zhao,C.-M. , Kuh, G. \& Carini, R. } \\
\text { M. (2005). A comparison of } \\
\text { international student } \\
\text { engagement and American } \\
\text { student engagement in effective } \\
\text { educational practices. Journal of } \\
\text { Higher Education, 76(2), 209- } \\
\text { 231. }\end{array}$ & & & & 1 & & & 1 & & & & & 1 & \\
\hline $\begin{array}{l}\text { Zhao, M. \& Wildemeersch, D. } \\
\text { (2008). Hosting foreign } \\
\text { students in European } \\
\text { universities: International and } \\
\text { intercultural perspectives. } \\
\text { European Education, 4a1), 51- } \\
62 \text {. }\end{array}$ & & & & & & & & & & & & 1 & \\
\hline
\end{tabular}




\title{
Universitetsuddannelsens relevans i samfundsvidenskabelige studerendes perspektiv
}

\author{
Laura Pérez Skardhamar, ph.d., pæedagogisk specialkonsulent og projektleder i \\ Pæedagogisk Center Samfundsvidenskab, Københavns Universitet
}

\author{
Charlotte Baarts, ph.d., lektor og studieleder ved Sociologisk Institut, Køben- \\ havns Universitet
}

\section{Videnskabelig artikel (anonym peer-review)}

\begin{abstract}
Det seneste årti har oplevet et stærkt fokus fra politikernes side på den praktiske relevans af universitetsuddannelser, og dette fokus har ofte været baseret på en snæver forståelse af 'praktisk relevans' som jobspecifikke kompetencer. Men et svar på spørgsmålet om, hvad der udgør jobspecifikke kompetencer, forudsætter en evne til at se ind i fremtiden og se, hvad det fremtidige arbejdsmarked vil kræve af studerende. Imidlertid tyder nyere uddannelsesforskning på, at de relevante, jobspecifikke kompetencer rettet mod behovene på arbejdsmarkedet bor fokusere på 'eksistentiel uddannelse' snarere end jobspecifikke og snævert skræddersyede færdigheder. På baggrund af kvalitative interviews med sociologiog antropologistuderende undersøger vi de studerendes opfattelser af forholdet mellem deres universitetsstudier og det fremtidige arbejdsmarked. Især ser vi på hvilke elementer af deres uddannelse, de studerende opfatter som relevante, herunder hvilken form for læring, de tror, vil være nyttig med hensyn til mulige jobfunktioner, de vil komme til at udfylde på et fremtidigt arbejdsmarked.
\end{abstract}

\section{Indledning}

Universitetsloven stiller krav til universitetsuddannelserne om at bedrive forskningsbaseret uddannelse, et krav som det, siden Karl Wilhelm Humboldt (1767-1835) udkastede sine visioner for videregående uddannelse, har været de danske universiteters kongstanke at realisere. Inden for uddannelsesforskning er der enighed om, at forskningsbaseret uddannelse er en central komponent i de studerendes læring (Robertson \& Blackler, 2006; Brew, 2010; Healey \& Jenkins, 2009; Levy et al., 2013), idet det anses for vitalt for alle studerende at udvikle evnen til at foretage vurderinger på basis af robust viden, undersøge problematikker, træffe rationelle beslutninger og forstå grundlaget for disse (Brew, 2010: 141). I forlængelse heraf har vi i det seneste årti været vidne til et stigende politisk fokus på, at ikke kun professionshøjskoler og professionsorienterede fag men også universitetsuddannelserne i højere og højere grad skal styre uddannelserne i retning af arbejdsmarkedsrelevans med særligt fokus på udvikling af kandidaternes arbejdsrelevante kompetencer (e.g. Udvalg for Kvalitet og Relevans i de Videregående Uddannelser, 2015). Desuden synes uddannelse at indgå som et centralt virkemiddel og parameter for konkurrencestatens succes (jf. Pedersen, 2014). I denne udvikling er spørgsmålet, om det ikke netop er gennem forskningsbaseret uddannelse, at universitetsuddannelserne opfylder regeringernes agenda for arbejdsmarkedsrelevant uddannelse; det vil sige, ved at udvikle de studerendes evne til at analysere og løse problemer som fagpersoner gennem involvering og aktiv deltagelse i forskning og forskningslignende aktiviteter? I den sammenhæng er det centrale spørgsmål, hvad de studerende selv oplever som relevansen af, at deres uddannelse er forskningsbaseret. 
På uddannelserne i Sociologi og Antropologi ved Københavns Universitet er størstedelen af undervisningen forskningsbaseret. Baseret på kvalitative interviews med sociologi- og antropologistuderende ved Københavns Universitet undersøger vi i denne artikel, hvad de studerende forstår ved relevans af deres uddannelse og desuden, hvordan de skaber sammenhæng mellem deres studier og forestillinger om det fremtidige arbejdsmarked.

\section{Teori}

Den britiske uddannelsesforsker Ronald Barnett rejser spørgsmålet om, hvad det vil sige at lære (2012), når læringen retter sig mod en fremtid, der - for studerende - er ukendt? Hvilken slags læring, spørger han, er den rette, når fremtiden netop ikke kendes (ibid)? Spørgsmålet er ikke bare generelt relevant i uddannelsesmæssig sammenhæng, men også specifikt med fokus på det politiske ønske om, at studerende skal udvikle arbejdsmarkedsrelevante kompetencer gennem deres universitetsstudier. Hvilke arbejdsmarkedsrelevante kompetencer skal studerende tilegne sig i forhold til det arbejdsmarked, de skal ud på efter fem års studier? Hvad ved vi egentlig om hvilke kompetencer, der til den tid vil blive efterspurgt? Og hvilke kompetencer kan siges at være arbejdsmarkedsrelevante? Det umiddelbare svar på disse spørgsmål synes at være 'generiske kompetencer', som kan anvendes i en mangfoldighed af situationer, selv i de situationer vi ikke på nuværende tidspunkt kan forudsige må opstå. Imidlertid er svaret ifølge Barnett ikke 'generiske kompetencer', men snarere at iværksætte en pædagogik for mennesket (Barnett, 2012:254). Herved foreslår han et skift for universitetslæring fra fokus på viden og kompetencer til en orientering mod de menneskelige kvaliteter og dispositioner som er en forudsætning for at skabe en positiv agenda i en grundlæggende usikker og superkompleks verden (Bamett, 2007:159). I nedenstående model ses Barnetts forslag til skitsering af pædagogiske muligheder for læring ved universitetet (figur 1):

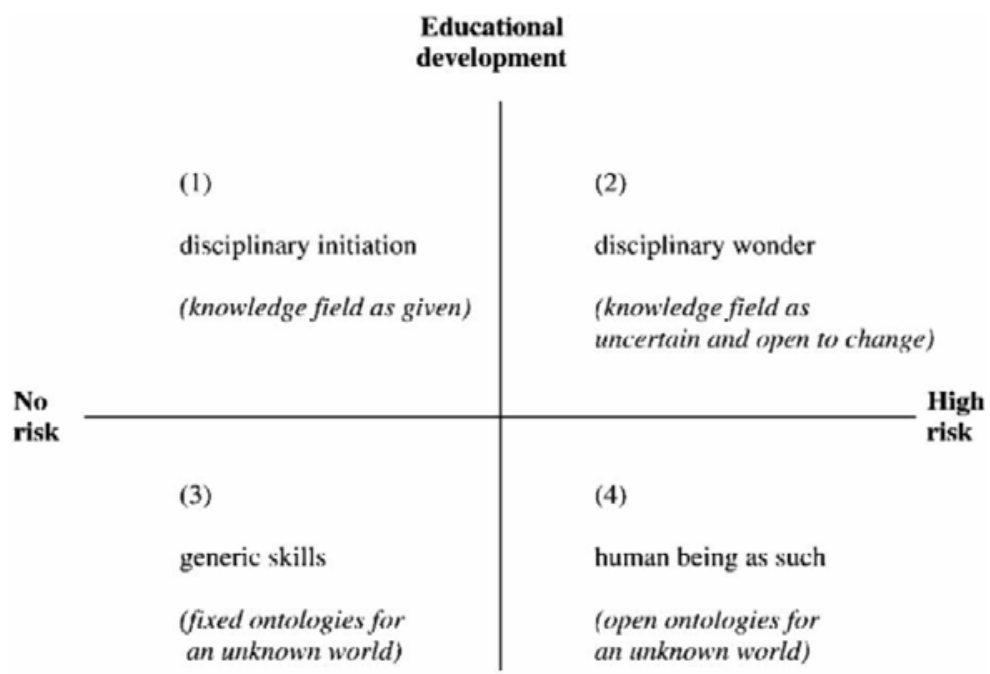

$$
\begin{gathered}
\text { Educational } \\
\text { transformation }
\end{gathered}
$$

Figure 1. Pedagogical options: a schema.

Figur 1: Læring på universitetet (Barnett, 2012: 72)

Modellen er bygget op af to akser, som tilsammen skaber fire felter for læringsmuligheder på universitetet. Modellens vertikale akse indikerer, hvorvidt fokus er på uddannelsesmæssig udvikling, der henviser til læring af forskellige kompetencer, eller uddannelsesmæssig transformation, som refererer til læring som menneskelig dannelse. Den horisontale akse viser graden af den studerendes oplevede risiko fra ingen risiko til høj risiko. 
Ud fra dette tegner de fire felter i modellen fire forskellige pædagogiske tilgange til læring ved universitetet, der har fokus på henholdsvis 1) 'faglig indvielse', 2) 'faglig undren', 3) 'almene færdigheder' og 4) 'eksistentiel dannelse'.

Med afsæt i disse fire beskrivelser af læringsmuligheder for studerende ved universitetet undersøger vi, hvorvidt og eventuelt hvordan disse opfattelser af læring forankrer sig blandt de studerende på uddannelserne i henholdsvis Sociologi og Antropologi. Vi retter særligt opmærksomheden imod, hvordan de studerende taler om relevans af deres studier i forhold til de opfattelser, de måtte have af den fremtid og det arbejdsmarked, som er dem både ukendt og usikkert. Ved at bruge Barnetts model som analytisk greb kan vi få blik for, hvordan de studerende etablerer forbindelser mellem på den ene side deres forestillinger om, hvad der for dem udgør relevante kompetencer i fremtiden, og på den anden side deres forståelser af, hvad de lærer og burde lære ved universitetet.

I feltet øverst til venstre bliver de studerendes læringsmuligheder konstitueret ved fokus på uddannelsesmæssig udvikling ved lav risiko. Dette indebærer, hvad Barnett kalder en 'faglig indvielse', hvor det vidensfelt, den studerende skal tilegne sig viden om, og som er nyt og ukendt for dem, er givet på forhånd. Læringsmålet er, at den studerende udvikler sin forståelse og sine kompetencer inden for den bestemte disciplin. Risikoen er lav, fordi det handler om, at den studerende tilegner sig den etablerede viden inden for faget.

I feltet øverst til højre er læringsmulighederne igen repræsenteret gennem uddannelsesmæssig udvikling, men ved høj risiko. Dette indebærer, at de studerende i højere grad bliver inviteret til at deltage aktivt i de undervisningsmæssige aktiviteter således, at de udvikler egne praksisser og tilgange til de læringsmæssige aspekter. Herved udgør læringsmålene i nogen grad et fokus på transformation af de studerendes kompetencer. Den læring, der her tilbydes, er udvikling af 'faglig undren', hvorved læringen synes at være en slags reproduktion af akademiske identiteter (ibid.:256). Dette er forbundet med en større risiko og usikkerhed, fordi der er mere fokus på den studerendes selvstændige deltagelse $\mathrm{i}$ at definere og producere ny faglig viden og mindre på tilegnelse af eksisterende viden inden for faget.

I feltet nederst til venstre bliver læringsmulighederne skabt gennem en tilgang, hvor transformation af de studerende er i fokus gennem lav risiko. Dette indebærer paradoksalt nok, at de studerende i nogen grad skal bringes ud af deres akademiske domæne med henblik på at danne sig således, at de kan begå sig i en tiltagende foranderlig verden. Undervisningen søger at danne de studerende ved tydeligt at definere, hvilke 'almene færdigheder' de skal udvikle.

Endelig tilbyder det sidste felt læring gennem uddannelsesmæssig transformation ved høj risiko. Læringsrummet skal kunne få de studerende til at danne sig gennem undervisningsformer, der hverken er etablerede eller sikre, men derimod udfordrende og eksperimenterende, og som ligeledes afslører, at viden, læring og dannelse er komplekse fænomener, der hele tiden udvider sig, snarere end bliver til begribelige fænomener. Gennem sådan 'eksistentiel dannelse' bliver læringsmulighederne til (ibid.:257).

\section{Metode}

Det empiriske materiale er tilvejebragt gennem 13 kvalitative interview med sociologi- og antropologistuderende ved Københavns Universitet i 2012. Interviewene varede ca. 1-2 timer. Der er en overvægt af sociologistuderende i materialet. De interviewede var på både kandidat- og bachelorniveau (5. eller 6 . semester), alle i 20'erne, og ligeligt fordelt mellem kønnene. Det empiriske materiale blev til i forbindelse med et kursusforløb ved Sociologisk Institut, hvor de tilmeldte studerende i samarbejde med kursets fagansvarlige (bl.a. denne artikels forfatter) skulle producere empiri med henblik på at undersøge studerendes forståelser og erfaringer med forskningsbaseret undervisning ved universitetet. 
I forbindelse med analysen af disse aspekter blev vi opmærksomme på, at det empiriske materiale rummer mange refleksioner om relevansen af de studerendes studier i forhold til anvendelsen af de lærte kompetencer på et fremtidigt arbejdsmarked, hvorfor vi har gjort dette til genstand for undersøgelse i nærværende artikel.

Idet vi således har genbesøgt det empiriske materiale med henblik på at identificere de studerendes forskellige forståelser af relevans i en kvalitativ tilgang inspireret af fænomenografisk metode (jf. Aswin, Abbas \& Mclean, 2014; Åkerlind, 2007). Med en empirisk sensitivitet over for interviewmaterialet samt empirisk kompleksitet har vi fokuseret vores blik på varianser i de studerendes relevansforståelser. Vi har i en iterativ metodisk proces kodet materialet på tværs af de interviewede studerende og har dermed ikke fokus på den enkelte studerendes meningsdannelse og livshistorie. Med denne metode har det været muligt at identificere tilstedeværelsen af multiple rationaler om værdien af det lærte og relevante kompetencer blandt de studerende.

Artiklen falder i tre dele. Efter denne indledning præsenteres analyseresultater i tre afsnit med tre forskellige relevansforståelser samt et afsnit med diskussion af disse fund. Artiklen afrundes med en konklusion, der opsummerer resultaterne.

\section{II . Variation i de studerendes forståelse af relevans i uddannelsen}

Samtalerne med de studerende reflekterer, at de skelner mellem uddannelsen på universitetet på den ene side og det, de kalder "virkeligheden derude", på den anden side. Denne adskillelse antyder, at de studerende opfatter læring under uddannelsen som adskilt fra anvendelse af deres læring i praksis. I nærværende artikel udfolder vi ikke dette skel yderligere, men noget tyder på, at de studerende kan opfatte universitetet og arbejdsmarkedet som to meget forskellige kontekster for anvendelse af deres læringsmæssige kompetencer således, at det lærte på universitetet ikke nødvendigvis slår til på arbejdsmarkedet eller korresponderer med arbejdsmarkedets praksis og behov.

\section{Relevans som teoretisk erkendelse der danner grundtilgangen til verden}

Spørgsmålet om, hvad de studerende kan bruge deres uddannelse til, når de er færdige, rejser de studerende bl.a. i forbindelse med deres overvejelser over, hvilken relevans det har, at de bliver undervist i teori:

\section{"[...] Og mange siger jo også, "hvad er det jeg skal bruge det her til, når jeg kommer ud i den virkelige verden, jeg skal jo ikke sidde og nørde teori". Men jeg mener stadig, at det ligger som en del af vores grundforståelse, at vi har væeret igennem det teori, vi har. Det kan godt væere, det ikke kommer direkte ud, når du sidder og skal lave en eller anden arbejdsopgave, men det ligger alligevel implicit i din tilgang til verden og en problematik og sådan noget."(Kandidatstuderende).}

Som den studerende udtrykker det, repræsenterer fagets teoretiske perspektiver en grundlæggende forandring i den studerendes færden i og møde med verden samt i måden, hvorpå den studerende beskæftiger sig med faglige spørgsmål. Derfor har teori relevans, selvom teori kan opleves, som den studerende antyder, som noget, der vanskeligt finder plads i en arbejdsmæssig sammenhæng ude i "den virkelige verden". Idet den studerende ikke alene anerkender, men også værdsætter, at der opdyrkes en implicit tilgang til verden i forbindelse med teoriundervisningen, formulerer den studerende en forståelse af læringens relevans, som placerer sig i Barnetts fjerde position (figur 1, felt 4). Læringsforståelsen repræsenterer ikke et fokus på udvikling af specifikke kompetencer eller avancement i den faglige viden, men netop på uddannelsesmæssig transformation sådan, at teoriundervisningen menes at styrke og skabe en kvalificeret forandring $\mathrm{i}$ selve den studerendes refleksive tilgang til egen og etableret viden om verden.

En anden studerende er også optaget af uddannelsens teori- og videnskabsteoriundervisnings relevans for arbejdsmarkedet: 
IP: "Ja helt sikkert. Jeg har en ide om, at vi har meget videnskabsteori i forhold til andre, og det, synes jeg, er en styrke på mange måder. Måske ikke på arbejdsmarkedet, men i hvert fald, når man studerer, synes jeg."

I:" Er det noget som du interesserer dig for - videnskabsteori?"

IP: "Ja, enormt meget, men jeg har også lidt en anelse om, at det er rigtig godt nu, mens man studerer, men jeg ved ikke, hvor meget man kan bruge det, hvis man skal have et rigtigt arbejde. Men jeg synes, at den der måde at kunne vurdere kvaliteten af den viden, man opnär og hvordan osv., er ret interessant. [....]. Altså, jeg tror, det er det, der er styrken ved det videnskabsteori, vi lærer. Og det hænger også lidt sammen med det, jeg sagde om sammenhæenge, at man har sådan en bagvedliggende teori, som gor en i stand til at se nogle storre sammenhæenge."(Bachelorstuderende).

Skønt den studerende ikke umiddelbart vurderer, at hun i læringen af videnskabsteori udvikler relevante arbejdsmarkedskompetencer, identificerer hun en anden slags relevans ved faget, der peger på, at videnskabsteoretisk viden gør den studerende i stand til at vurdere kvaliteten af anden viden, se sammenhænge og identificere bagvedliggende strukturerer for disse sammenhænge. Denne relevansforståelse refererer også til Barnett-modellens fjerde position (felt 4), hvor læringsmålene er, at studerende kan navigere i det, Barnett kalder åbne ontologier og i en kontinuerlig foranderlig væren som sådan (Bamett, 2012: 72). Skønt begge studerende ovenfor formulerer en forestillet afstand fra det, de lærer på universitetet, til det, der skal bruges på arbejdsmarkedet, italesætter ingen af dem dette som et problem. Tværtimod formulerer de deres identifikation af afstand mellem læring af teori og arbejdsmarkedsrelevante kompetencer til en for dem meningsfuld forståelse af, at faglig (teoretisk) viden udgør en selvstændig og væsentlig del af deres dannelse. Hermed bliver deres tolkning af relevansen af det lærte på uddannelsen sat i relation til deres forestillinger om, hvad de forventer, at det lærte kan bruges til i et "rigtig arbejde". I denne relevansforståelse bliver det at være universitetsstuderende, få teoretiske og metodologiske erkendelser samt at komme tæet på forskning tilskrevet mening og værdi i sig selv. Det drejer sig om en art eksistentiel dannelse, hvor undervisning og læring understøtter den studerende i at forandre sig og opdyrke en grundlæggende refleksiv tilgang til verden.

\section{Relevans som det at bruge faget til at gøre en forskel}

Foruden opdyrkelsen af en åben og refleksiv grundtilgang til (viden om) verden omtaler de studerende også relevans af deres uddannelser i forhold til at kunne gøre en forskel og ændre noget i samfundet eksempelvis i forhold til udsatte grupper:

"Det er jo fx når man undersøger eller beskæftiger sig med nogle emner hvor at - ja det handler måske om nogle udsatte grupper eller nogle menneskers liv som man - ikke sådan det enkelte individ eller de personlige historier, men mere sådan - når man laver en undersøgelse af nogles identitet. Et projekt jeg har lavet med [xx-]identitet, hvor man undersøger noget, som vedrører nogle mennesker, og som handler om deres liv, og hvor man kan bruge det, også i nogle storre samfundsperspektiver. Det bliver sådan utrolig omt, men det der med faktisk at kunne bruge viden til at gøre, måske gøre nogle menneskers liv bedre eller pàpege nogle problematikker i samfundet. Det er det, jeg gerne vil, og det er der, hvor jeg synes, det bliver rigtig fedt."(Bachelorstuderende).

Den studerende finder uddannelsen særlig relevant i de sammenhænge, hvor fagene involverer aktuelle samfundsmæssige emner, eller hvor hun i projektarbejde kommer i kontakt med menneskers levede liv. I disse sammenhænge bliver det særligt tydeligt for den studerende, at læringen under uddannelsen kan anvendes i praksis til forhåbentlig at 
gøre en mærkbar og positiv forskel for de involverede personer eller grupper. Det væsentlige i denne relevansforståelse er, at faget anvendes til at analysere nogle konkrete problemstillinger i samfundet, og at dette ændrer noget for nogle konkrete mennesker.

I Barnetts model placerer den studerendes relevansforståelse sig på den vertikale akse for uddannelsesmæssig udvikling i anden position (figur 1, felt 2), som omhandler "faglig undren" snarere end den horisontale akse for uddannelsesmæssig transformation. Fagets viden og begreber skal bruges til at gøre en forskel for andre mere eller mindre konkrete målgrupper i samfundet snarere end til den studerendes egen dannelse som en værdi i sig selv. Den skabte faglige viden bliver et udgangspunkt for handling. Således er den studerendes læring og vidensproduktion forbundet med en vis grad af risiko i den forstand, at den studerende selvstændigt definerer problemer og hermed producerer (potentielt) ny viden inden for faget. I dette ønskes den faglige viden omsat til at kunne gøre en forskel i verden uden for den faglige forskningsdisciplins grænser.

Pointen om at gå til grænserne for den eksisterende faglige viden i faget er også tydelig i det næste citat, hvor den studerende ikke kun er optaget af at skabe håndgribelig forandring i samfundet for konkrete mennesker men også er optaget af at gå til grænsen for den eksisterende viden:

\section{l: "Hvorfor er det spændende at se tingene på andre måder? Hvorfor er det en god ting?" \\ IP: "Hvorfor? Ja det er svært at sige hvorfor, jeg tror bare, at det virker inspire- rende, eller at det, ja det tror jeg, jeg tror ikke rigtig, jeg kan komme det nær- mere. Jeg tror også, jeg synes, at det er vigtigt, at man har sådan en fantasi, så- dan én, at man kan forestille sig, at tingene kunne være anderledes, end de er." I: "Okay, hvorfor?" \\ IP: "Jamen, fordi ellers så kan der jo ikke ske nogen forandring, hvis man bare tror, at verden er, som den er, og sådan er det, men jeg synes, det er vigtigt, at mennesker generelt kan forestille sig, at tingene kunne blive set på en anden måde, eller at samfundet kunne bygges op på en anden måde eller sådan. "(Ba- chelorstuderende).}

Den studerende refererer til nogle grundlæggende faglige kvalifikationer og færdigheder i relation til samfundsopbygning inden for såvel sociologien som antropologien, der vedrører kritisk refleksion og det at stille spørgsmålstegn ved fagets eksisterende selvfølgeligheder ved brug af det, den studerende omtaler som (faglig) "fantasi". Læring af en sådan faglig fantasi har for den studerende praksisrelevans i forhold til generelt at kunne skabe forandringer og udvikle samfund. Denne forståelse placerer sig som nævnt i Barnetts anden position (figur 1, felt 2) med vægt på uddannelsesmæssig udvikling og samtidig med vægt på, at udvikling kræver, at der tages en stor risiko ved at stille sig undrende og kritisk refleksiv over for fagets eksisterende forståelser og begreber. Mens de samfundsvidenskabelige studerendes første relevansforståelse kan siges at have stor vægt på eksistentiel dannelse i sig selv og mindre vægt på praksisrelevans, er relevansforståelsen her netop fokuseret på, hvad der kan blive relevant i praksis.

\section{Relevans som tilegnelse af redskaber og generalistkompetencer}

I de første to analytiske temaer vedrørende henholdsvis teori og at gøre en forskel indstiftede de studerende et skel mellem læring under uddannelse og anvendelse af denne i "virkeligheden derude" på arbejdsmarkedet. I det følgende analyseafsnit bliver adskillelsen mellem universitetet og "virkeligheden derude" mindre væesentlig, når de studerende taler om relevans som tilegnelse af redskaber og specifikke kompetencer. Et bud på opløsningen af dette skel kan være, at læring af specifikke kompetencer i de studerendes øjne har direkte overførbarhed mellem universitetet og arbejdsmarkedet, hvorved skellet opløses. 
IP: "[...]J eg kan bare rigtig godt lide at vide sådan "okay jamen, det er her jeg sidder og lærer nu, hvad vil jeg sådan faktisk kunne bruge det til?". Jeg klikker fra, hvis ikke jeg ved, hvad jeg kan bruge det til, hvis jeg synes, at en teori ikke er anvendelsesdygtig eller en metode, jeg lærer, ikke er sådan konkret nok til, at jeg kan sige, okay når jeg så skal søge et studiejob, så kan jeg sige til min arbejdsgiver: jeg har lært det her, og det kan du bruge, derfor kan du bruge mig til det og det", eller sådan. Det har jeg brug for på det her studie, som nogen gange godt kan blive sådan lidt oppe i skyerne. "(Bachelorstuderende).

Uddannelsens relevans knytter sig for den studerende direkte til, hvad hun konkret kan formidle til en potentiel arbejdsgiver om, hvad hun kan, og dermed hvad hun kan bruges til. Den studerende etablerer meget målrettet en lineær forbindelse mellem læring af teori og metode og konkret anvendelse af disse i praksis. I de tilfælde, hvor en sådan forbindelse ikke kan skabes, bliver uddannelsesindholdet for denne studerende irrelevant. En tilsvarende relevansforståelse er på spil for den studerende i nedenstående citat: IP: "[...] Og så har jeg jo en forestilling om, at det er det, jeg skal arbejde med, at det er den måde, jeg skal arbejde pà. Jeg har ikke en forestilling om, at jeg skal forske, men jeg har en forestilling om, at jeg skal arbejde i en virksomhed som skal lave denne her form for analyser. Og det har jeg jo lært i den opgave, jeg har i hvert fald fået et lille indblik i hvordan man kunne gøre det."(Bachelorstuderende).

I ovenstående knytter den studerende direkte forbindelser mellem brugen af en bestemt slags analyser, som hun vurderer er anvendelige i såvel den skriftlige universitetsopgave som i en forestillet opgave stillet af en bestemt analysevirksomhed. På uddannelsen kan hun øve sig i at gennemføre disse analyser og på den baggrund bruge dem på kompetent vis, sà snart hun sidder i en stilling, hvor hun skal udarbejde dem i en virksomhed. Den studerendes relevansforståelse er således stærkt optaget af, at der skal være direkte overensstemmelse mellem det, der læres på uddannelsen, og det, der kan bruges i arbejdslivet.

\section{De tre relevansforståelser og betydning for universitetspæedagogikken}

I Barnetts model placerer dette sig i tredje position (figur 1, felt 3), hvor læringen orienterer sig mod læring af almene færdigheder, der med relativ stor sikkerhed vil finde anvendelse i en endnu ukendt fremtid. Det er for eksempel specifikke metoder og analysetilgange samt almen analytisk kompetence, som tegner de studerendes opfattelse af, hvad der er relevant læring her, og der tages ingen risiko. På den vertikale akse placerer de studerendes relevansforståelse sig i positionen: uddannelsesmæssig transformation, fordi fokus ikke er på traditionel fagindviende universitetsuddannelse, hvor det handler om at avancere i den faglige forståelse som i Barnetts første position (figur 1, felt 1) og heller ikke om at udvide den faglige forståelse ved at gå til grænsen af det kendte som i den anden position (figur 1, felt 2). Relevansforståelsen handler her om at klæde den studerende på til at navigere på et fremtidigt og derfor ukendt arbejdsmarked ved at optræne akademiske generalistkvalifikationer og -færdigheder.

Mens den første relevansforståelse, som de studerende forankrede i læring af teori, kan beskrives som eksistentiel funderet og som tæt forbundet med Barnetts vision om en pædagogik for mennesket med primært fokus på de menneskelige kvaliteter og dispositioner, italesætter de studerende gennem den anden relevansforståelse et ideal for praksisrelevant læring, der udfordrer grænserne for den faglige disciplin gennem ønsket om at bruge sin faglighed til at gøre en samfundsmæssig forskel for særligt udsatte grupper af mennesker. Sidst, men ikke mindst, har de studerendes italesættelse af denne tredje relevansforståelse fokus på praktisk relevante færdigheder og kompetencer, der kan bruges en til en på arbejdsmarkedet. 
Til den politiske agendas fokus på uddannelsens arbejdsmarkedsrelevans tilføjer denne analyse således en kvalitativ indsigt i de studerendes egne forståelser af den forskningsbaserede uddannelses relevans. Analysen viser, at relevansen ikke er isoleret til erhvervsrettede generalistkompetencer men også indbefatter en oplevelse af at blive eksistentielt dannet som menneske og fagperson. Dette er ifølge Barnett netop det, der skal til, for at den studerende er klædt på til en ukendt fremtids problemer og udfordringer. Til udvikling af den forskningsbaserede uddannelse inden for universitetspædagogikken åbner dette op for mange udfordringer og muligheder, herunder ikke mindst spørgsmålet om og svaret på, hvordan undervisning og læring med høj risiko kan styrkes og få mere plads til udfoldelse inden for den eksisterende uddannelsesstruktur.

\section{I I. Konklusion}

De samfundsvidenskabelige studerende italesætter tre kvalitativt forskellige opfattelser af relevans af det, de lærer på uddannelsen. For det første beretter de studerende om værdien af eksistentiel dannelse som en udviklende del af teori under uddannelsen på universitetet. For det andet beretter de studerende om værdien af fagets viden og de faglige kvalifikationer og færdigheder, som gør den studerende i stand til at tænke nyt om og løse konkrete problemstillinger og dermed forhåbentligt gøre den studerende i stand til i et arbejdsliv at gøre en positiv forskel for konkrete grupper af mennesker i samfundet. For det tredje beretter de studerende om nødvendigheden af, at de tilegner sig generelle akademiske færdigheder og kompetencer, som de kan bruge direkte på arbejdsmarkedet. Ved brug af Barnetts teoretiske model som analyseramme får vi et unikt indblik i, hvordan en flerhed af diskursive rationaler er på spil i specifikke sociologiog antropologistuderendes forholden sig til relevansen af deres uddannelse.

Artiklen peger på, at de studerende er bemærkelsesværdigt nuancerede og dynamiske i deres forståelser af uddannelsens relevans i et spænd fra erhvervsrettede generalistkompetencer til teoretisk dannelse. Med afsæt i Barnetts vision kan ovenstående indsigt i de studerendes egne nuancerede forståelser tolkes som et konkret eksempel på, at de nødvendige menneskelige kvaliteter og dispositioner som et superkomplekst samfund behøver, kommer til udtryk blandt disse specifikke samfundsvidenskabelige studerende i denne specifikke kontekst.

Laura Pérez Skardhamar har siden marts 2013 væeret pæedagogisk specialkonsulent og projektleder i Pæedagogisk Center Samfundsvidenskab, Københavns Universitet. Hun arbejder med uddannelsesudvikling og samarbejde på tværs af universitetets fakulteter i projekter om forskningsbaseret uddannelse og internationalisering samt adjunktsupervision mv. Lauras forskningsinteresser centrerer sig om kulturanalytiske tilgange til undervisning, læering og praksisrelationer på videregående uddannelser.

Charlotte Baarts er lektor og studieleder ved Sociologisk Institut, Københavns Universitet, Hendes forskningsinteresser centrerer sig om undersøgelse af forskellige vidensformer, $f_{x}$ kropslig og sproglig viden, og hvordan disse praktiseres. Dette forhold mellem viden og kunnen har hun beskæftiget sig med inden for områder som arbejdsmiljø og sikkerhed, alternative behandlingsformer samt forskningsbaseret uddannelse. Sidstnæevnte er et igangværende forskningsprojekt blandt såvel forskere som studerende ved universitetet.

\section{Litteratur}

Aswin, P., Abbas, A. \& Mclean, M. (2014). How do students' accounts of sociology change over the course of their graduate degrees? Higher Education, 672), 219234.

Barnett, R. (2012). Learning for an unknown future. Higher Education Research and Development, 23(3), 247-260.

Barnett, R. (2007). The Will to Learn: Being a Student in an Age of Uncertainty. New York: Society of Research into Higher Education \& Open University Press. 
Brew, A. (2010). Imperatives and challenges in integrating teaching and research. Higher Education Research and Development, 29 (2) 139-150.

Healey, M. \& J enkins, A. (2009). Developing students as researchers. Proceedings of the Newport NEXUS conference. Centre for Excellence in Learning and Teaching, special publication, No. 1, 7-11.

Levy, B. L. M.; Thomas, E. E., Drago, K. \& Rex, L. A. (2013). Examining studies of inquiry-based learning in three fields of education: Sparking generative conversation. Journal of Teacher Education, 64(5), 387-408.

Pedersen, K. O. (2014). Konkurrencestaten. København: Hans Reitzels Forlag.

Robertson, J. \& Blackler, G. (2006). Students' experiences of learning in a research environment. Higher Education Research and Development, 25(3), 215-229.

Udvalg for Kvalitet og Relevans i de Videregående Uddannelser (2015). Nye veje og høje mål. Kvalitetsudvalgets forslag til reform af de videregående uddannelser. Downloaded den 15/8-2015: http://ufm.dk/publikationer/2015/nye-veje-og-hojemal.

Åkerlind, G. S. (2007). Variation and commonality in phenomenographic research methods. Higher Education research \& Development, 24(4), 321-334. 


\title{
Kvalitet i danske masteruddannelser - Et spørgsmål om kompetenceudvikling eller akademisk dannelse?
}

\author{
Nikolaj Stegeager, lektor, Institut for Læring og Filosofi, Aalborg Universitet
}

\section{Videnskabelig artikel (anonym peer-review)}

\begin{abstract}
Denne artikel beskæftiger sig med de danske masteruddannelser. Med udgangspunkt i en undersøgelse fortaget i forbindelse med forfatterens ph.d. - projekt (afsluttet i sommeren 2014) vil artiklen på baggrund af en verserende debat om masteruddannelsernes kvalitet og relevans diskutere kvalitet i dansk akademisk videreuddannelse. Den kvalitative undersøgelse, der ligger til grund for artiklen, anskueliggør, at selvom de studerende oplever, at de gennem deres toårige studie har tilegnet sig en række konkrete og brugbare kompetencer, peger de på andre og mere transformative læeringskvaliteter, når man beder dem om at beskrive det vigtigste udkomme af deres uddannelsesforløb. Artiklen argumenterer for, at denne læering, der i højere grad kan siges at knytte sig til personen i form af en etisk-eksistentiel dannelse frem for en specifik kunnen, har nær sammenhæeng med det at befinde sig i et akademisk, videnskabeligt miljø. På dette grundlag søger artiklen at problematisere aktuelle forslag om at slække på kravet til masteruddannelsernes videnskabelige fundament for i stedet at fokusere på mere instrumentelle, erhvervsrettede kompetencer og færdigheder.
\end{abstract}

De danske masteruddannelser har i deres nuværende form eksisteret i omtrent 15 år siden indførelsen af Videreuddannelsessystemet for voksne. ${ }^{1}$ På mange måder er der tale om en stor succeshistorie. Således fremgår det af Danmarks Statistik, at antallet af danske HD- og masterstuderende er vokset fra 9.000 i 1999 til 17.280 i $2014^{2}$, mens en opgørelse offentliggjort i Politiken den 15/11 2008 viser, at antallet af udbudte masteruddannelser er gået fra 13 i 1998 til 103 i 2008, og i dag er der mere end 125 forskellige masteruddannelser fordelt på Danmarks 8 universiteter. Tallene indikerer således, at der er et udtalt behov for længerevarende, akademiske videreuddannelser i Danmark. Et behov der blandt politikere og meningsdannere ofte beskrives som behovet for at opkvalificere den danske arbejdsstyrke og dermed sikre danske organisationers fortsatte konkurrencedygtighed på et stadig mere globalt marked (OECD, 2004; Undervisningsministeriet, 2007). Ganske interessant er vores viden om masteruddannelsernes evne til at imødekomme dette behov - altså deres evne til (som Masteruddannelsesbekendtgørelsen tilsiger) "på videnskabeligt grundlag at kvalificere medarbejdere til at varetage højt specialiserede funktioner i virksomheder" (Ministeriet for Forskning, 2009) - ganske underbelyst (Stegeager, 2014a). I det følgende opsummeres de væsentligste punkter fra de få undersøgelser, der trods alt forefindes på området.

\section{Effekt af akademisk videreuddannelse}

Fra Videreuddannelsesreformens indstiftelse i 2000 og ti år frem forefindes primært undersøgelser eller evalueringer af enkeltstående masteruddannelser (Ulveman, 2005; EVA, 2004; Krogh, 2003; Krogh \& J ensen, 2009; EVA, 2009). Disse undersøgelser har typisk et lokalt præg, der sigter mod optimering af det konkrete pædagogiske produkt frem for generel viden om akademisk videreuddannelse. Inden for de seneste 3-4 år, har vi dog

\footnotetext{
${ }^{1}$ Videreuddannelsessystemet for voksne var en væsentlig nyskabelse i Videreuddannelsesreformen fra 2000. Systemet fungerer som et parallelt system til det ordinære uddannelsessystem.

${ }^{2}$ http://pub.uvm.dk/2000/videre/4.htm og http://www.dst.dk/Site/Dst/Udgivelser/nyt/GetPdf.aspx?cid=20660.
} 
set flere undersøgelser, som beskæftiger sig med masteruddannelserne i mere almen og generel forstand (Kristensen \& Skipper, 2010; Lorentsen \& Niemann, 2010; EVA, 2013; Damvad, 2013).

Fælles for disse undersøgelser er, at alle finder, at uddannelserne bibringer de studerende ny viden og indsigt. Derimod er det væsentligt sværere at dokumentere uddannelsernes effekt på organisatorisk niveau. Lorentsen og Niemann (2010) finder, at mens 99,8 procent oplever at have fået ny viden og indsigt, er det kun omkring 60 procent, der har foretaget ændringer i deres daglige arbejde efter endt uddannelse. Kristensen og Skipper (2010) finder i deres omfattende undersøgelse af offentligt finansieret videreuddannelse generelt en insignifikant sammenhæng mellem virksomheders investering i offentlig videreuddannelse og organisatorisk output i forhold til tre parametre: Vækst i antallet af ansatte, omsætning pr. medarbejder samt overskud pr. medarbejder. Modsat denne undersøgelse finder Damvad (2013) en produktivitetsgevinst forbundet med at have flere ansatte med en master eller en HD. Undersøgelsen er imidlertid en korrelationsundersøgelse og rummer derfor visse svagheder i forhold til at sige noget om kausalitetsforholdet mellem akademisk videregående uddannelse og organisatorisk produktivitet. Alt i alt kan man konkludere, at de eksisterende undersøgelser peger på, at masteruddannelserne er velegnede til at bibringe studerende ny viden, mens det er mere usikkert, om de også gør en forskel i organisatorisk henseende.

\section{Hvad skal vi med de danske masteruddannelser?}

Ovenstående forhold har givetvis medvirket til at igangsætte en debat om masteruddannelsernes kvalitet. Debatten blev intensiveret med et notat udarbejdet af ACE Denmark i 2012, i hvilket organisationen blandt andet pointerer, at masteruddannelserne har problemer med at skabe tilstrækkelig sammenhæng mellem uddannelserne og de studerendes arbejdserfaringer (ACE Denmark, 2012).

Et af de centrale temaer i debatten om masteruddannelsernes kvalitet og relevans har derfor omhandlet spørgsmålet om, hvorvidt det er meningsfuldt - som angivet i Masterbekendtgørelsen - at insistere på en tydelige akademisering (undervisning på videnskabeligt grundlag), eller om uddannelserne i højere grad skal fokusere på praktiske, erhvervsrettede kompetencer, der lettere lader sig omsætte i de studerendes praksis. Således udtaler daværende formand for ACE Denmark Søren Barlebo i 2012 følgende:

Masteruddannelserne skal både være forskningsbaserede og praksisorienterede, men det kan være en svær kombination at opfylde. Spørgsmålet er derfor, om masteruddannelser behøver at være forskningsbaserede på samme måde, som de er i dag. Måske kan vi koble praksisorienteringen med et højt, forskningsbaseret fagligt niveau på andre og mere hensigtsmæssige måder? (Berlingske, 29/8 2012).

Det samme spor forfølger afdelingschef i politisk/økonomisk afdeling hos AC, Niels Lykke Jensen:

Hvornår har man senest defineret, hvad man vil med masteruddannelserne, og hvordan de skal tilrettelægges, så deltagerne får mest ud af dem? Det har man vel nærmest aldrig gjort... Der er masser af fremragende masteruddannelser, men hvis jeg selv skulle ud og betale for det, så ville jeg ikke føle mig sikker. Man kan risikere at købe katten i sækken (Altinget, 17/8 2012).

Begge udtalelser kan ses som et udtryk for en strømning, som man også ser i kvalitetsudvalgets nylige rapporter om kvalitet i de videregående uddannelser, hvor uddannelseskvalitet (sat lidt på spidsen) primært forstås som uddannelsernes anvendelighed i arbejdslivet (Kvalitetsudvalget, 2015). 
Denne forståelse kan i mine øjne medføre en opprioritering af et noget instrumentelt læringssyn, og samtidig risikerer man at overse centrale kvaliteter ved det nuværende system, hvilket uddybes nedenfor.

\section{Metode}

Undersøgelsen, som ligger til grund for denne artikel, er et kvalitativt studie, der beskæftiger sig med studerendes oplevelser på Master i Organisatorisk Coaching og Læring ved Aalborg Universitet, der er en deltidsuddannelse, som typisk læeses over to år. Uddannelsens primære målgruppe er ledere og konsulenter. Undersøgelsen følger to årgange (38 studerende) gennem en periode på tre år (fra tiden inden uddannelsesstart til et år efter færdiggørelse - 2009-2012) og tager udgangspunkt i følgende undersøgelsesspørgsmål: ${ }^{3}$

Hvad lærer de studerende på masteruddannelsen, og hvordan bruger de det, de har lært?

Følgende datakilder benyttes i undersøgelsen for at besvare undersøgelsesspørgsmålet:

- De studerendes ansøgningsskemaer med et dertil hørende kort notat om deres motivation for deres ansøgning til masteruddannelsen.

- Observationsnoter fra undervisningsseminarer.

- De studerendes masterprojekter.

- Evalueringer udfyldt en måned efter endt uddannelse.

- Semistrukturerede interviews foretaget et år efter endt uddannelse

Analysen af data tager udgangspunkt i Grounded Theory og særligt i Glaser og Strauss' (1967) 4-fase matrix-model:

1. Begrebsliggørelsen af det overordnede tema

2. Grovinddeling af data i almene kategorier

3. Inddeling i underkategorier

4. Yderligere inddeling i finere kategorier

Alle datakilder er analyseret ud fra denne matrix. Efter analysen af de forskellige datamaterialer er der foretaget en sammenligning for at identificere fælles temaer i materialerne. Disse fælles temaer danner udgangspunkt for besvarelsen af undersøgelsens forskningsspørgsmål.

\section{Metodekritik}

Undersøgelsen er et kvalitativt casestudie, hvorfor man naturligvis skal være varsom med at slutte fra fundene i undersøgelsen til de danske masteruddannelser i almindelighed. Casestudiet giver ikke mulighed for generalisering. En af casestudiets væsentligste styrker er derimod, at det giver mulighed for at sætte fokus på kompleksiteten i menneskelig aktivitet og dermed giver mere nuancerede fremstillinger af komplekse forhold og sammenhænge (Flyvbjerg, 2001). Casestudiets vigtigste opgave er således ikke at komme frem til et endegyldigt og uigenkaldeligt resultat. Derimod bør resultatet af et kvalitativt studie, som David Hildebrand (2003) påpeger, opfattes som invitation til videre fortolkning og fortsat konversation. Resultaternes værdi ligger i deres funktion ikke i deres forudsigelseskraft. Når dette er sagt, vil jeg dog samtidig påpege, at resultaterne, som gengives i denne artikel, har et klart sammenfald med andre lignende undersøgelser af akademisk videreuddannelse (Ulveman, 2005; EVA, 2012; EVA, 2013).

\footnotetext{
${ }^{3}$ Undersøgelsen indeholder endvidere en lang række underspørgsmål, som ikke har relevans i denne sammenhæng.
} 
Resultater - Hvad har de studerende lært ved at tage en masteruddannelse?

Af den afsluttende evaluering fremgår det, at de studerende oplever, at uddannelsen har bidraget til deres udvikling som ledere og konsulenter. I evalueringen svarer alle studerende, at de "i høj grad" eller "i meget høj grad" har forbedret deres kompetencer i forhold til at iværksætte individuelle såvel som organisatoriske forandringsprojekter. På samme vis oplever alle, at uddannelsen har medvirket til at nuancere deres forståelse af leder- eller konsulentpositionen som platform for forandringsprocesser. Når man beder de studerende om at beskrive, hvordan de har søgt at bringe det, de har lært på uddannelsen i spil i hverdagen, peger de på en række konkrete samt mere abstrakte forhold. Eksempelvis konkrete samtaleredskaber og -teknikker, samt forskellige metodiske arbejdsmåder (systematik, undersøgelsesmetoder m.m.) som de i dag bruger i andre, ikkeuddannelsesrelaterede sammenhænge. På mere overordnet plan fortæller de studerende, at deres professionelle fokus har forandret sig i løbet af deres uddannelse. Typisk er deres opgaver steget i kompleksitet. Mange af de studerende oplever, at de efter endt uddannelse får eller tager sig adgang til at arbejde i nye sammenhænge, hvor opgaverne i højere grad har et organisatorisk og strategisk udgangspunkt. Et eksempel på dette kan ses $\mathrm{i}$ interviewene, hvor stort set alle ledere fortæller, at uddannelsen har medført en ændring i deres ledelsesstil fra ledelse af opgaven til ledelse af personalet - som derefter løser opgaven. Et af de ord, der går igen, er uddelegering. De fortæller, hvordan de er blevet mere opmærksomme på, at ledelse ikke nødvendigvis består i at definere og stå i spidsen for én bestemt løsning men at sikre rammer, der gør det muligt for medarbejderen at definere egne løsninger. En leder beskriver det således:

Jeg er mindre struktureret og mindre styrende, selvom det se/vfølgelig på en eller anden måde også er at være struktureret. Jeg går mere ind i opgaverne med den tanke: "Gud ved hvad der mon sker?", og så lader jeg tingene komme. (Stegeager, 2014a:184).

\section{Fra kompetenceudvikling til personlig transformation}

Det er imidlertid ikke beskrivelser af praksisrelaterede kompetencer, som fylder mest i de studerendes læringsbeskrivelser. Langt oftere beskriver de deres læring på anden vis. Eksempelvis fortæller én, at hun "i højere grad hviler i sig selv", mens en anden fortæller, at han har "fundet en anden ro". Alle interviewene foretaget et år efter endt uddannelse kredser om disse mere flydende og svært definerbare læringseffekter. På baggrund af de studerendes udsagn har jeg identificeret tre specifikke læringsbeskrivelser, som går igen i stort set alle interviews: ${ }^{4}$

- Refleksion - en insisteren på at udsætte en naturlig handleimpuls til fordel for eftertænksomhed og overvejelse.

- Mod - en større tro på egne evner og beslutninger, en øget vilje til at igangsætte nye tiltag samt en øget fornemmelse af legitimitet i faglige sammenhænge.

- $\quad$ Nysgerrighed - en generel åbenhed over for det mulighedsfelt, som ethvert spørgsmål eller problemstilling åbner op til. Forbedret flertydighedstolerance.

Der er flere interessante forhold ved ovenstående tre punkter. For det første er der et stort sammenfald mellem disse beskrivelser og andre lignende undersøgelser (EVA, 2012; EVA, 2013). Dette indikerer, at disse læringsoplevelser ikke er noget, der knytter sig specifikt til den pågældende uddannelse. Endvidere finder jeg det interessant, at læ-

\footnotetext{
${ }^{4}$ De studeredne bruger ikke nødvendigvis ordret disse tre begreber, men deres fortællinger er overraskende enslydende. Alle centrerer sig om samme tematik, og jeg har på den baggrund valgt disse tre begreber, som i mine øjne indfanger fortællingernes primære budskab.
} 
ringsmålene i den pågældende masteruddannelses studieordning ikke specifikt nævner de ovenfor beskrevne kvaliteter, hvorfor man med en vis ret kan hævde, at disse centrale læringskvaliteter kan siges at være afledte effekter af undervisningen - ikke noget som uddannelsen specifikt og eksplicit søger at fremme. Man kan således spekulere i, at denne læring, som de studerende gentagne gange fremhæver som helt centralt for deres uddannelsesforløb, ikke nødvendigvis kan tilskrives det faglige indhold (pensum) i de fagspecifikke uddannelsesmoduler, men i højere grad centrerer sig om at være i en akademisk uddannelseskontekst. ${ }^{5}$

Man skal i denne sammenhæng dog være opmærksom på, at undersøgelser af læring i andre, ikke-akademiske uddannelsessammenhænge ${ }^{6}$ ligeledes finder forhold, som minder om de ovenfor beskrevne, hvorfor man med et vist belæg kan hævde, at disse forhold ikke nødvendigvis knytter sig til de akademiske uddannelsesinstitutioner, men måske i højere grad knytter sig til selve det at uddanne sig. Dog skal jeg senere i teksten argumentere for det særlige potentiale, der i mine øjne knytter sig til de akademiske uddannelser.

De ovenfor nævnte læringseffekter, beskrives af de studerende som forhold, der i dag gennemsyrer hele deres måde at være i verden på. Denne læring relaterer sig i mindre grad til specifikke færdigheder eller kompetencer (at kunne noget bestemt) men omhandler forandringer, man med udgangspunkt i Jack Mezirows (1991) arbejde kan beskrive som transformativ læring ${ }^{7}$ og dermed læring, der indebærer ændringer i de studerendes opfattelse af omverden og sig selv - kort sagt deres identitet (Illeris, 2014). De oplever således alle at have forandret sig undervejs i deres uddannelsesforløb - forandringer, der i mindre grad refererer til den kompetenceudviklende, kvalifikationsoptimering som masterbekendtgørelse og studieordning lægger op til, og i højere grad refererer til måden, de er i verden på. Nedenstående citater eksemplificerer de studerendes beskrivelser af disse transformative forandringer:

Det er fordi, at når jeg igen kigger fra et lidt højere abstraktionsniveau og ned på det, jeg foretager mig i min ledergerning og jo også som mennesket Arne, så har det på den gode måde inficeret hele mit daglige virke. Det er jo også i spil, når jeg sidder og forhandler med leverandører eller sidder og snakker økonomi. Hele min tilgang til det at være leder. Til det at få folk i spil og få fundet ind til, hvad folk tænker og mener og få overskuet kompleksiteten, det er med. Og det kan godt være, at det lyder sådan lidt stort, men det er faktisk med i min ledergerning. Det er blevet en integreret del af mig. Derfor tænker jeg også, at jeg bærer det med hele tiden. (Stegeager, 2014a: 193).

Der hvor jeg har uddannelsen med, tror jeg, man kan beskrive som sådan en klangbund, jeg har med mig. Det er mere sådan en anden opmæerksomhed på nogle ting. (Stegeager, 2014b: 146).

\section{Kompetencer eller dannelse?}

Når jeg i denne artikel fremhæver netop disse resultater fra min undersøgelse, skyldes det, at de i mine øjne leverer et væsentligt bidrag til den igangværende debat om kvalitet og relevans i danske masteruddannelser. Gennem de sidste 30 år har man kunnet registrere et markant skift i europæisk voksenuddannelsesdebat og -politik, fra en overvejende humanistisk, udviklingsorienteret til en økonomisk, vækstorienteret uddannelses-

\footnotetext{
${ }^{5}$ Hvilket kan medvirke til at forklare de enslydende resultater fra undersøgelser af forskellige uddannelser.

${ }^{6}$ Se eksempelvis J acobsen (1991).

${ }^{7}$ Mezirow definerer transformativ læring således: “Learning that transforms problematic frames of reference to make them more inclusive, discriminating, reflective, open, and emotionally able to change" (Mezirow, 2009:22).
} 
forståelse (Rubenson, 2005; Rubenson, 2006; Rasmussen, 2009; Bengtsson, 2013). Når topfolk i ACE Denmark og AC giver udtryk for et ønske om at forøge masteruddannelsernes erhvervsfokus gennem en øget instrumentalisering af undervisningen og en deraf følgende nedprioritering af uddannelsernes akademisk videnskabelige orientering, er det efter min opfattelse et udtryk for en videreførelse af denne tendens.

Jeg mener imidlertid, at det er væsentligt at gøre op med tanken om et klart modsætningsforhold mellem en humanistisk- og en samfundsøkonomisk uddannelsesforståelse mellem uddannelsers nytteværdi og deres akademisk, dannende kvalitet. ${ }^{8}$ Naturligvis skal akademiske videreuddannelsesaktiviteter interessere sig for de studerendes arbejdserfaringer og uddannelsens evne til at sikre, at de studerende kan bruge uddannelsen i arbejdssammenhænge. Samtidig mener jeg imidlertid, at der med udgangspunkt i min undersøgelse er grund til at overveje, om kritikerne af masteruddannelserne overser eller undervurderer potentialet i de eksisterende uddannelser, når de udtrykker deres ønske om i endnu højere grad at målrette masteruddannelserne mod arbejdsmarkedet gennem en ændring af uddannelsernes indhold. J eg mener således, at der er al mulig grund til at udvise en sund skepticisme overfor kravet om målbar nytteværdi som primær (eneste) målestok for universiteternes virke.

Min (samt adskillige andre) undersøgelse af akademisk videreuddannelse påviser, at studerende er vældig glade for måden, hvorpå langt de fleste uddannelser søger at sammenkoble undervisning og arbejdsliv. I midlertid er det også tydeligt, at deres optagetheder og læring i forbindelse med uddannelsen peger i mange forskellige retninger, og samlet set kan man konstatere, at meget af den læring, de selv fremhæver som vigtig for dem som fagpersoner, ikke har en direkte kobling til det tilegnede fagspecifikke indhold men i højere grad knytter sig til måden, hvorpå de opfatter sig selv som fag- og privatpersoner. Kvaliteter der i mine øjne kan tilskrives uddannelsernes akademisk videnskabelige fundament.

Som Taylor (2012) skriver, baserer transformativ uddannelse sig på, at den lærende udfordres til kritisk refleksion over egne forforståelser og værdier, hvilket potentielt kan medføre ændringer i måden at forstå sig selv og verden på. ${ }^{9}$ Når de studerende i undersøgelsen beretter om masteruddannelsens særlige, transformative læringskvalitet, er det imidlertid vigtigt at være opmærksom på, at undervisning på uddannelsen ikke sigter mod transformativ læring (identitetsudviklende undervisning). Uddannelsen indeholder ingen elementer, der har den studerendes personlige udvikling som fikspunkt. Det er derimod det konstante fokus på sagen - uddannelsens ambition (som fremhævet i studieordningen ${ }^{10}$ ) om, at de studerende skal opøve færdigheder i selvstændig, systematisk og kritisk refleksion over praksis, der tvinger dem til at stille spørgsmålstegn ved egne taget-for-givne-antagelser og dermed ved sig selv.

\footnotetext{
${ }^{8}$ Begrebet "akademisk dannelse" fremstilles her med inspiration fra Solberg (2010) og Hansen (2012). Solberg og Hansen skelner i deres arbejde mellem to forskellige former for akademisk dannelse. En traditionel dannelsesforståelse, hvor den studerende gør sig kendt med en bestemt lærdomstradition (pensum) og en etisk-eksistentiel dannelse. Med udgangspunkt i Kants dannelsesforståelse skriver Solberg, at en vigtig opgave for Akademia er at udvikle den studerendes indre blik på sig selv - en selvforståelse eller med Solbergs ord en "egenstemme", for, som hun skriver: "uten utvikling av en egen stemme vil en mangle den form for faglig basert originalitet og kreativitet som kjennetegner den gode forsker" (Solberg, 2010:56). Der er således en tydelig konneks mellem Mezirows begreb om transformativ læring og Solbergs og Hansens forståelse af etisk-eksistentiel dannelse.

${ }^{9}$ Det er dette forhold, der i mine øjne gør de akademiske uddannelser særlige i denne henseende (jæunfør den tidligere reference til Jacobsens (1991) fund af uddannelseseffekt i andre mere instrumentelle uddannelsessammenhæng), eftersom den akademiske disciplin i høj grad baserer sig på kritikken som udgangspunkt for udvikling af viden og forståelse (Willig, 2007). Af denne grund mener jeg, at man med en vis ret kan hævde, at de akademiske uddannelser qua deres kritisk, refleksive udgangspunkt rummer et stort potentiale for transformativ læring eller etisk-eksistentiel dannelse.

10 http://www.aau.dk/digitalAssets/90/90835_83724_studieordning_ma_organisatorisk_coaching_og_laering_2014_h um_aau.pdf
} 
Jeg blev udfordret i en grad, der i perioder gav mig søvnløse nætter og nærmest eksistentielle refleksioner. "Hold da op hvor er jeg dum! Jeg forstår simpelthen ikke". Mit møde med den stringente 'Hvordan-og-hvorfraved-du-det-du-ved? - og Hvad-ved-du/ser-du-samtidig-ikke?'-kultur på universitetet, har udfordret mine egne mere personligt erfarede antagelser. (Stegeager, 2014b:201).

Den eksisterende debat om universitetets rolle i videreuddannelsessystemet risikerer qua det udprægede fokus på produktions- og virksomhedsoptimering i mine øjne at underminere undervisning med udgangspunkt i den kritisk, refleksive forholdemåde, der er universitetets kendetegn og styrke og udgangspunkt for de centrale læringskvaliteter, jeg har fremhævet i denne artikel. J eg vil derfor hævde, at der i en tid, hvor universitetet oplever et stadig større pres for at efterkomme samfundets krav om anvendelsesorienteret modus 2 forskning ${ }^{11}$ (Gibbons, 1997) og ditto undervisning, er grund til, at vi som universitetsundervisere og fagspecialister inden for læring og uddannelse fortsat insisterer på, at den fagspecialiserede og kontekstuafhængige vidensproduktion ligeledes må og skal være en del af universitetets opgave - ikke kun i forskningssammenhænge, men ligeledes i måden, hvorpå universitetet lærer fra sig. Det er således, universitetet kan levere nytteværdi i en videreuddannelsessammenhæeng - vel at mærke en nytteværdi som er væsentligt mere nuanceret (og kvalificeret) end den snævre økonomiske forståelse, der ofte bruges som definerende pejlemærke.

Nikolaj Stegeager er cand.psych., ph.d. og lektor med fokus på laering i voksenlivet i et individ- og organisationsperspektiv ved Institut for Læring og Filosofi, Aalborg Universitet. Nikolaj underviser på en lang række masteruddannelser, ligesom han gennem mere end fem år har fungeret som koordinator og uddannelsesansvarlig på to forskellige masteruddannelser. Nikolajs forskning beskæftiger sig især med voksenpædagogik, uddannelsesplanlægning samt forholdet mellem uddannelse og organisatorisk praksis.

\section{Litteratur}

ACE Denmark (2012). Notat om masteruddannelser: niveau og vurdering i forbindelse med akkreditering. København: ACE Denmark.

Bengtsson, J. (2013). National strategies for implementing lifelong learning (LLL): an international perspective. International Review of Education, 59(3), 343-352.

Damvad (2013). Værdien af HD og masterprogrammer - For dimittenderne og for virksomhederne. København: Copenhagen Business School.

Europa-Kommissionen (2010). GRØNBOG. Frigørelse af de kulturelle og kreativetive industriers potentiale. https://publications. europa.eu/da/publication-detail//publication/1cb6f484-074b-4913-87b3-344ccf020eef/language-da (set 13.11.2015).

EVA (2004). Master of Public Health. København: Danmarks Evalueringsinstitut.

EVA (2009). Evaluering af master $i$ it. København: Danmarks Evalueringsinstitut.

EVA (2012). Lederuddannelsers betydning for ledelsespraksis. København: Danmarks Evalueringsinstitut.

EVA (2013). Undersøgelse af masteruddannelserne. København: Danmarks Evalueringsinstitut.

\footnotetext{
${ }^{11}$ Ifølge Gibbons (1997) repræsenterer Modus 2 forskning en ny måde at anskue videnskabeligt arbejde på. Mens traditionel (Modus 1) forskning ifølge Gibbons er karakteriseret ved at beskæftige sig med faglige problemer, der er knyttet til en fagdisciplin i et konkret akademisk miljø med en vis konserverende træghed til følge, repræsentere Modus 2 forskning en anvendelsesorienteret vidensproduktion. Denne forskning vurderes ud fra et relevanskriterium præget af samfundsmæssige og kommercielle interesser. God forskning i dette perspektiv kan således defineres som forskning, der skaber øget samfundsmæssig værdi.
} 
Flyvbjerg, B. (2001). Making Social Science Matter. Cambridge: Cambridge University Press.

Gibbons, M. (1997). What kind of university? Research and teaching in the 21st century. Beanland lecture. Melbourne: Victoria University of Technology.

Glaser, B. G. \& Strauss, A. L. (1967). The Discovery of Grounded Theory. Chicago: Aldine.

Hansen, F. T. (2012). Om akademisk dannelse i dag - med udgangspunkt i Gadamer's syn på sandhed og erfaring. Norsk filosofisk tidsskrift, 473), 208-220.

Hansen, S. L. (2014). Lego, Novo og Carlsberg på jagt efter humanister. Ugebrevet Mandag Morgen (30. juni 2014).

Hildebrand, D. L. (2003). Beyond Realism and Antirealism: John Dewey and the Neopragmatists. Nashville: Vanderbilt University Press.

Illeris, K. (2014). Transformativ læring \& identitet. København: Samfundslitteratur.

Jacobsen, B. (1991). Studier i dansk voksenundervisning og folkeoplysning. København: Akademisk Forlag.

Kristensen, N. \& Skipper, L. (2010). Effektanalyser af voksenefteruddannelse - Analyse af private virksomheders brug af offentlig medfinansieret voksenefteruddannelse og effekterne på virksomhedernes udvikling. København: AKF, Anvendt Kommunal Forskning.

Krogh, L. (2003). Det er faktisk morsomt at lære og fordybe sig - også selvom en travl hverdag tager sin tid. I: K. E. Andreasen, I. G. Bo \& H. D. Keller (red.): Perspektiver på rum og forandring, 178-204. Aalborg: Aalborg Universitetsforlag.

Krogh, L. \& Jensen, A. (2009). Lifelong learning: Master education - personal development or/and professional competence development? 17th Improving Student Learning Symposium. London: I mperial College.

Kvalitetsudvalget (2015). Nye veje og høje mål - Kvalitetsudvalgets samlede forslag til reform af de videregående uddannelser. København: Uddannelses- og Forskningsministeriet.

Lorentsen, A. \& Niemann, K. (2010). $150 \mathrm{~km} / \mathrm{t}$ på en grusvej. Om voksnes rammer for efter/videreuddannelse. Aalborg: Aalborg Universitetsforlag.

Mezirow, J. (1991). Transformative Dimensions of Adult Learning. San Francisco: JosseyBass.

Ministeriet for Forskning (2009). Masterbekendtgørelsen. Bekendtgørelse om masteruddannelser ved universiteterne.

OECD (2004). Lifelong Learning. OECD Observer.

Pedersen, M. F. (2014). Humanister er mere værd end du tror. Ugebrevet A4 (28. Oktober 2014).

Rasmussen, P. (2009). Lifelong learning as social need and as policy discourse. I: R. Dale $\&$ S. Robertson (red.): Globalisation and Europeanisation in Education, 85-100. Oxford: Symposium Books.

Rubenson, K. (2005). Livslang læring: en kritisk vurdering af det politiske projekt. I: K. Illeris \& S. Berri (red.): Tekster om voksenlæring, 253-266. Frederiksberg: Roskilde Universitetsforlag.

Rubenson, K. (2006). The Nordic model of lifelong learning. Compare, 363), 327-341.

Solberg, M. (2010). Akademisk dannelse - med utgangspunkt i Kants sensus communis og Hva er oplysning? I: L. Dybdal (red. ), Festskrift til Hjørdis Nerheim i anledning 70-årsdagen, 51-68. Tromsø: Tromsø Universitet.

Stegeager, N. (2014a). Viden i bevægelse - Et studie af masterstuderende i spændingsfeltet mellem uddannelse og arbejdsplads.Aalborg: Aalborg Universitet.

Stegeager, N. (2014b). Viden i bevægelse - Et studie af masterstuderende i spændingsfeltet mellem uddannelse og arbejdsplads (Bilagssamling). Aalborg: Aalborg Universitet. 
Taylor, E. W. (2012). Fostering transformative learning. I: J . Mezirow \& E. W. Taylor (red.): Transformative Learning in Practice: Insights from Community, Workplace, and Higher Education, 3-17. San Francisco: J ossey-Bass.

Ulveman (2005). En kvalitativ undersøgelse af langtidseffekter af Masteruddannelser. København: Københavns Universitet.

Undervisningsministeriet (2007). Danmarks strategi for livslang læring - Uddannelse og livslang opkvalificering for alle. Redegørelse til EU-kommissionen. København: Undervisningsministeriet.

Willig, R. (2007). Til forsvar for kritikken. København: Hans Reitzels Forlag. 


\title{
Fire trin mod udbytterige studenteroplæg - hvordan præsentationer i undervisningen høj- ner fagligheden og bliver en positiv oplevelse
}

\author{
Linda Greve, ph.d.-stipendiat, uddannelsesudvikler, Center for Undervisning og \\ Læring, Aarhus BSS, Aarhus Universitet
}

Faglig artikel (bedømt af redaktionen)

Studenteroplæg er en både meget anvendt og meget udskældt disciplin. I denne artikel foretages fire nedslag for at hjæe/pe undervisere med mere tydeligt at rammesætte studenteroplæg som læringsaktivitet. De fire nedslag er: 1) Længe for oplægget, hvor aktiviteten indlejres i faget; 2) lige for oplægget hvor underviseren låner lidt af sin troværdighed til den studerende, der skal holde oplæg; 3) under oplægget, hvor underviseren har fokus på aktiv lytning og 4) efter oplægget, hvor feedback på oplagget hjælper de studerende med at få et fagligt sprog. Artiklens fokus er at klæde undervisere på til at få en hensigtsmæessig praksis i forhold til studenteroplæg.

\section{Introduktion: Studenteroplæg i undervisningen}

Studenteroplæg er gavnlige på flere parametre. De studerende lærer mere ved selv at skulle formidle fagligt stof, de får erfaring med at præsentere foran et publikum, og de får mulighed for feedback på deres forståelsesniveau (MacAlpine, 1999). Alligevel ender studenteroplæg alt for ofte med, at de studerende står med ryggen til publikum og læser højt af slides, og at feedbacken bliver usammenhængende og ukonstruktiv. I denne artikel beskrives, hvordan undervisere kan arbejde med at højne niveauet af studenteroplæg i undervisningen gennem fire trin: længe før oplægget, lige før oplægget, under oplægget og efter oplægget. Formålet med at gribe studenteroplæg an på denne måde er at højne læringen hos både den studerende, der holder oplægget, og hos dem, der lytter og giver feedback.

Artiklens faglige ståsted er i retorikken. De metoder, der bliver præsenteret nedenfor, er således situeret i en metodisk tilgang til forberedelse (se fx Greve, 2011; McCroskey, 2001). Uden at gennemgå retorikkens fem forberedelsesfaser slavisk ${ }^{1}$ vil der dog i det følgende være referencer til, hvordan studerende hjælpes til både at lave bedre oplæg og at få gode oplevelser med at holde oplæg, som i høj grad er inspireret af de fem faser. Fokus i artiklen er ikke at beskrive, hvordan man laver gode oplæg, men hvordan man som underviser skaber de fornødne rammer for, at aktiviteten får et udbytte, der svarer til indsatsen både i form af tid i undervisningen og forberedelsestid hos den studerende samt i læringsudbytte.

Ud over funderingen i klassisk retorik er det også centralt at understrege artiklens fundering i en mundtlig tradition (Ong, 2013). Påstanden er, at idealet for et godt studenteroplæg ikke er, hvor tæt det er på skriftlighed, men hvor levende, engagerende og målgrupperettet det er. Det er således med fuldt overlæg, at der tales om oplæg og ikke om præsentationer. Ordet 'præsentationer' konnoterer nemt PowerPoint-præsentationer, og

\footnotetext{
${ }^{1}$ De fem forberedelsesfaser er (oversat til dansk): 1) idéudvikling, 2) disponering, 3) sprog og stil, 4) husketeknik og 5) fremførelse. Logikken i de fem faser er, at man starter med at udforske kommunikationssituationen og på den baggrund opbygger sit oplæg $\mathrm{i}$ indhold, stil, visualisering for sig selv og publikum og endelig selve oplægget.
} 
selvom der ikke er det mindste galt med at anvende teknologi til at visualisere sine pointer, bliver PowerPoint nemt til et manuskript i punktform, man deler med sit publikum. Det ideal, der søges fremelsket i denne artikel, er et relaterende og kommunikerende ideal snarere end et indstuderet og skriftligt ideal. Det handler om at give de studerende rum til frit at udfolde deres forståelse af et fagligt emne og uden den bedømmelse, der ligger til grund for eksamenspræstationer. Det er således vigtigt, at underviseren rammesætter studenteroplæg som en læringsaktivitet og ikke som en bedømmelsesaktivitet: Formålet med studenteroplæg er at styrke evnen til mundtlig argumentation og præsentation frem mod den afsluttende eksamen.

Artiklens klangbund er, ud over den teoretiske, forfatterens mangeårige erfaring med at undervise i præsentationsteknik både for studerende og undervisere samt anvendelse af studenteroplæg i egen undervisning.

Som undervisere har vi en meget stor indflydelse på, hvor vellykket et studenteroplæg bliver. Forståelsen af indholdet og evnen til at strukturere det kan vi i sagens natur ikke altid hjælpe med, men at skabe rammerne for en fagligt funderet kommunikation er underviserens ansvar. I det følgende vises, hvordan dette kan gøres ved brug af eksempler og teori samt forslag til øvelser.

\section{Længe før oplægget}

I planlægningen af undervisningen skal det indgå, om de studerende skal lave oplæg. Studenteroplæg passer godt băde til gennemgang af fagligt stof, til præsentation af gruppearbejde og til præsentation af produkter og af processer. De studerende lærer meget af at forberede et oplæg, og de lærer meget af at høre hinandens, hvis rammerne er klare og formålet tydeligt. Bhatti og Grøn (2014) påviser i deres undersøgelse af studerendes præferencer for undervisningsformer, at studerende foretrækker forelæsning frem for $\mathrm{fx}$ studenteroplæg. En del af forklaringen på dette kan meget vel findes i, at rammerne og formålet er uklart, samt at legitimiteten af en medstuderendes undervisning vurderes lavere. Dette uddybes nedenfor. Hvis studenteroplæg er en del af undervisningen, så er det en fordel at lade dem starte tideligt i forløbet, så det bliver en del af kulturen. Det kan overvejes at lade alle studerende holde først et kort oplæg af redegørende karakter og senere på semesteret et længere og mere selvstændigt. På den måde startes der med noget relativt harmløst og arbejdes der hen imod noget mere selvstændigt og taksonomisk mere komplekst samtidigt med, at der opbygges en god kultur omkring det at holde og lytte til studenteroplæg.

Det er således vigtigt at implementere studenteroplæg som en del af enten læringsmål eller aktivitetskrav for at legitimere aktiviteten og fjerne al tvivl hos de studerende om, hvorvidt det er nødvendigt. Læringsmål kan både være rettet mod, at alle skal holde et eller flere faglige oplæg i løbet af kurset, og mod at alle studerende skal træne evnen til at give feedback på og diskutere fagligt relevant stof. På denne måde rammer læringsmålet både den, der holder oplægget, og de, der er aktivt lyttende.

Næste led er at lave klare rammer for oplægget. Hvor lang tid må det vare, hvilke krav er der til form og vigtigst af alt: hvad er formålet med, at de studerende skal holde oplæg? Disse tre spørgsmål er der ikke ét oplagt og rigtigt svar på. Hvis formålet er at få de studerende til at forstå og formidle fagligt stof, er det en fordel også at give dem god tid til det. Hvis de derimod skal pitche en løsning eller en idé, de har fundet frem til, er fem minutter måske nok, og det centrale er diskussionen og feedbacken bagefter.

Nogle studerende vil se det som en kvalitetsforringelse at skulle undervises af hinanden frem for af underviseren (Bhatti \& Grøn, 2014). Dette sker typisk fordi de studerende er statussensitive over for hinanden - de er formelt på samme niveau - og både for at beskytte sig selv mod at skulle stå foran kammeraterne og for at hævde status over mindre 
dygtige studerende, kan denne form for modstand opstå. Det er i den forbindelse afgørende at hjælpe de studerende til at forstå, hvilket formål aktiviteten tjener.

Ud over situeringen i læringsmål er det også vigtigt at udstikke klare retningslinjer for tid og indhold. Jo mere præcis formen er, desto mere ro har de studerende til at fokusere på indholdet. Hvis det er en kortere præsentation, kan Pecha Kucha overvejes som ramme (Klentzin, Paladino, J ohnston, \& Devine, 2010). De studerende har 20 billeder i hver 20 sekunder til at præsentere deres stof. ${ }^{2}$ Denne form kan med fordel bruges til præsentationer af løsninger og processer, men formen kan også anvendes til forskningsformidling. Formen kommer fra Japan. Pecha Kucha betyder 'snik snak'. Egentlig har metoden sit udspring i designindustrien, men den kan problemfrit også anvendes til forskningsformidling og pitching. Klentzin et al. fremhæver denne metode til pensumgennemgang som særligt velegnet og viser, at studerende kan lære lige så meget af den korte Pecha Kucha som af en traditionel PowerPoint-forelæsning.

Det meget faste format og kravet om illustrationer gør, at de studerende skal tænke lidt anderledes om deres emne, hvilket kan være en passende udfordring både for dem og for tilhørerne. Ulempen ved dette format er, at deltagerne ikke kan improvisere ret meget fordi 20 sekunder er meget kort tid.

Et element, det er vigtigt at tage med sig fra Pecha Kucha, er visualiseringen. Lad de studerende tænke visuelt og ikke kun tekstuelt om deres oplæg. Dermed undgår du, at oplægsholderen står og læser højt af sine slides eller sin skærm frem for at lade ordene og ideerne stå frem.

Et andet element, det er værd at tage med fra Pecha Kucha, er tidsopdelingen. Det er en fordel for den studerende, at der er taget stilling til, hvilke elementer der skal være i oplægget, og hvordan de tidsmæssigt skal disponeres. Underviseren kan med fordel lave en tidsplan, som de studerende selv skal fylde indhold i. Det tager igen fokus væk fra formen og retter det mod indholdet, og så hjælper det den studerende med at disponere stoffet, uden at du behøver at undervise i disponering af stof.

En plan kunne se således ud:

\begin{tabular}{l|l|l} 
Tid (minutter) & Tema & Illustration \\
\hline 3 min. & $\begin{array}{l}\text { Indledning i emnet } \\
\text { Emnets relevans } \\
\text { Oplæggets struktur }\end{array}$ & \\
\hline 13 min. & $\begin{array}{l}\text { Emnets baggrund } \\
\text { Redegørelse for synspunkter } \\
\text { Diskussion af synspunkter }\end{array}$ & \\
\hline 2 min. & $\begin{array}{l}\text { Perspektivering af emnet til resten af } \\
\text { faget }\end{array}$ & \\
& Oplæg til diskussion & \\
\hline I alt 15 minutter & &
\end{tabular}

Figur 1: Skema der hjælper de studerende til at disponere deres indhold og tid samt indikerer et krav om at anvende illustrationer

\footnotetext{
${ }^{2}$ PowerPoint og lignende programmer kan kodes til selv at skifte hvert 20. sekund. Det er relativt nemt at finde en Pecha Kucha-skabelon på nettet.
} 
Et skema skal naturligvis tilpasses det enkelte fag og fagområde og kan udbygges og nuanceres meget mere end vist ovenfor. Men gennem de elementer, der sættes ind, kommunikeres en ramme og en forventning til indhold, som fjerner en del af frustrationen over at skulle finde en god form og et godt indhold.

Når formålet med at anvende studenteroplæg er klart, og formen er tydelig, er forberedelsen længe før oplægget gjort. Herfra foregår arbejdet med studenteroplæg i selve undervisningslokalet.

\section{Lige før oplægget}

Netop på grund af studenteroplæggets symmetriske karakter - der kommunikeres til medstuderende - er det særligt vigtigt, at underviseren sætter rammen for studenteroplæg i undervisningslokalet. At rammesætning er centralt står at læse allerede hos Carsten Raft i 1945. Det er således ikke en ny indsigt, men ikke desto mindre er det fortsat en overset faktor:

Det er Taleren, der holder Talen - og den maa han selv klare! Men Foreningen eller Arrangørerne har ogsaa et ansvar. Forbereder de Mødet omhyggeligt og godt og indleder Mødets Leder paa den psykologisk rigtige Maade, kan det hjælpe Taleren stærkt; men er der sjusket med Mødets Forberedelse og Start, er det uhyre svært for selv den bedste taler at stride sig op mod de Vanskeligheder som ganske urimeligt og unyttigt er lagt ham i vejen. (Raft, 1945: 16).

Det er således vigtigt, at underviseren legitimerer oplægsholderen, repeterer formålet og rammen og giver ordet videre. Derved låner oplæegsholderen lidt af underviserens troværdighed og starter et bedre sted, end hvis han eller hun selv skal legitimere sin position som oplægsholder. Lader underviseren oplægsholderen selv tage ordet, sætte rammen og forklare lytternes rolle, får oplægsholderen et ansvar for processen, som rettelig tilfalder underviseren. En måde at legitimere en oplægsholder på er at introducere oplægsholder, formål og emne. I akademiske sammenhænge opleves det ofte, at der læses højt af vedkommendes meritter, og det er selvfølgelig sjældent muligt om studerende. Men indled med: den studerendes navn, studieretning (med mindre alle har samme studieretning), emne for oplægget og den rolle, lytterne har under oplægget. Små kommentarer som "jeg ser meget frem til at diskutere denne tekst med jer" eller "dagens emne er centralt for faget fordi ..." er ligeledes med til at sætte oplægsholderen og emnet ind i en ramme, hvor det er indholdet mere end personen, der er det interessante.

En del studerende bliver nervøse, når de skal holde oplæg. Selvom det fra et underviserperspektiv kan forekomme underligt, når det bare er deres medstuderende, der lytter, er det netop vigtigt at være opmærksom på troværdighed. Etos eller troværdighed hos taleren er en vigtig parameter for, om et oplæg lykkes. Initialetos, eller den troværdighed, som oplægsholderen har hos sine lyttere indledningsvist, påvirkes markant af lytternes repræsentation af oplægsholderen (McCroskey, 2001:87). Det er således ikke nok, at det, man siger, er rigtigt. Lytterne skal også tillægge oplægsholderen en troværdighed. I en symmetrisk situation, hvor oplægsholderen er under uddannelse, er initialetos notorisk lavt. Det kan underviseren mindske ved at sætte scenen for oplægsholderen og derved at udvise tiltro til den studerendes evner. Samtidig skal underviseren naturligvis være opmærksom på, at selvom det ikke er en bedømmelsessituation, så er der elementer af noget asymmetrisk, fordi underviseren skal eksaminere på et tidspunkt og i øvrigt er bedre inde i emnet end oplægsholderen.

Nervøsitet viser sig på mange måder. Enten som rysten på hænderne, røde pletter på halsen, udsving på stemmen, flakkende blik eller hektisk bevægelse. Det er meget naturligt og er et udslag af, at oplægsholderen er fysisk opmærksom på, at der skal præsteres. Lidt adrenalin er udmærket, men for meget kan naturligvis være forstyrrende. Me- 
gen nervøsitet kan overkommes i løbet af de første to minutter af oplægget. Så hvis en studerende på forhånd giver udtryk for nervøsitet, er det en fordel at indstudere de første minutter af oplægget ret nøje, for når de går godt, slapper kroppen mere af. Ligeledes er det indsatsen værd at lave en sikker afslutning. Det er med til at holde den etos, der er opbygget gennem oplægget. Hvis oplægget ender sikkert og troværdigt, er det både med til at styrke etos og med til at give oplevelsen af, at oplægget gik godt.

Gode indledninger består af:

- Relevansen for lytterne - en case, et eksempel eller konkrete anvendelsesmuligheder.

- Budskabet eller essensen af det, der kommer - det giver lytterne et pejlemærke at lytte med og viser en vinkel på det, der skal gennemgås.

- Et overblik over oplæggets elementer.

Ligeledes har gode afslutninger nogle karakteristika:

- Vend tilbage til indledningens case, eksempel eller anvendelsesmuligheder.

- Opsummer det mest centrale.

- Vis tydeligt med tale og kropssprog, at oplægget er slut. Fx "Det var, hvad jeg havde valgt at tage med i mit oplæg" eller "Tak fordi i lyttede, nu ser jeg frem til at diskutere det med jer" eller simpelthen "Tak for jeres opmærksomhed".

Hvis oplægget afsluttes tydeligt, er lytterne trygge. En oplægsholder, der afslutter med "Det var det, nu har jeg ikke mere" eller "Nå! Det var sidste slide ...", mister troværdighed.

En ting er naturligvis oplægsholderens etos og velbefindende. En anden ting er lytternes. Også lytterne har ekstra behov for faste rammer i en symmetrisk kommunikationssituation. Så hvis der skal gives feedback, eller lytterne skal have et særligt fokus undervejs i oplægget, er det vigtigt at få det på plads i god tid, før oplægget påbegyndes. I en symmetrisk kommunikationssituation er det en fordel at trække relationen mellem de studerende ud af det rent sociale rum. Derfor er det ofte en fordel at give tilhørerne en funktion også. Det kan være et fokusområde til feedback eller at være i stand til at stille tre spørgsmål til oplægsholderen bagefter. Dette behandles nærmere nedenfor i afsnittet "Efter oplægget".

Nu er scenen overgivet til oplægsholderen, og tilhørerne kender deres funktion. Det er tid til selve oplægget.

\section{Under oplægget}

Mennesker (og andre primater) spejler hinanden (Ferrari, Gallese, Rizzolatti \& Fogassi, 2003; Hickok, 2014). Det er fundamentalt for vores måde at kommunikere på, at vi afkoder hinandens intentioner og sindstilstande ved at se, høre og mærke (og til dels også lugte) hinanden. ${ }^{3}$ Det er relevant for studenteroplæg, fordi denne forståelse af hinanden påvirker kommunikationen.

Tilhørerne og underviseren kan på ganske kort tid ødelægge et ellers udmærket tilrette-

\footnotetext{
${ }^{3}$ Teorien om spejIneuroner har lidt en omtumlet tilværelse. Hickok betegner den som en teori, der har fået en tilværelse uden for laboratoriet, som der ikke er forskningsmæssig evidens for. Den grundlæggende teori var, at nogle af de neuroner. der er aktive. når vi selv udfører en handling. også er aktive. når vi ser andre af samme art udføre en handling (Ferrari, Gallese, Rizzolatti, \& Fogassi, 2003). En afledt konklusion af dette blev, at alt fra kommunikation til empati kan tilskrives spejlneuroner. Dette tilbageviser Hickok (2014). Men effekten af, at vi forstår hinanden ved at sanse hinanden, tilbageviser han ikke. Han tilskriver det blot ikke neuroner men derimod det, at hjerne og krop er tæt forbundne, og at vi lærer og forstår ved at imitere hinanden.
} 
lagt studenteroplæg ved at fremstå ligeglade, skeptiske eller engagerede i noget andet og mere spændende. Under oplægget er det således vigtigt, at underviseren er engageret i det, der foregår. Ligeledes har de øvrige studerende en rolle at spille. At gøre dem opmærksomme på dette ansvar - at man populært sagt ikke får bedre oplæg, end man har fortjent som lytter - er et underviseransvar. Om der skal opstilles regler for brug af IT under studenteroplæg, om bordene skal flyttes eller, hvordan det håndteres, er en smagssag. Men det er vigtigt at være opmærksom på, at markører som øjenkontakt, små nik og en venlig attitude er en væsentlig hjælp for oplægsholderen. For at illustrere dette kan følgende lille øvelse gennemføres:

- Bed de studerende fortælle sidemanden om et eller andet dagligdags ( $f x$ hvad de har lavet i morges eller, hvad de synes, var det mest interessante i dagens tekst).

- I plenum: lad dem redegøre for hvordan den lyttende part agerede.

- Bed dem nu gentage øvelsen, men hvor den, der lytter, gør det modsatte af, hvad en lytter normalt vil gøre

- I plenum: lad dem redegøre for hvordan det oplevedes både for taler og lytter.

Resultatet af øvelsen er typisk, at det er svært at holde tråden, når man modspejles. Det er svært at huske, fokusere og færdiggøre sætninger for taleren. For lytteren kan det ligeledes være grænseoverskridende at være "uhøflig". Lad de studerende overføre den gode lyttepraksis til situationer, hvor de hører oplæg fra hinanden, og undgå den modspejlende attitude.

Ved at have fokus på at trække oplægget ud af den sociale relation mellem studerende og ved at have fokus på troværdighed i en symmetrisk kommunikationssituation, hjælpes den studerende godt på vej til at få en positiv oplevelse med at holde oplæg. Når oplægget er slut, er det vigtigt ikke at lade det stå for sig selv men at give feedback eller lægge op til diskussion.

\section{Efter oplægget}

Når oplægget er afsluttet, er det underviserens rolle at agere moderator. Jo mere de studerende selv arbejder sammen om at højne forståelse og diskutere forskellige positioner desto bedre. Underviserens funktion er at sikre, at samtalen følger reglerne, og at de studerende ikke arbejder videre med en forståelse, der er forkert.

Der kan vælges flere feedback-strategier. Her vil jeg præsentere tre forskellige vel vidende, at det langt fra er en udtømmende liste. Feedback defineres i denne sammenhæng som kommunikationsprocesser, der lader studerende fokusere på præstation og indhold gennem dialog (Liu \& Carless, 2006). De skal ikke vurdere eller bedømme hinanden, men indgå i dialog for at udvikle faglig argumentation og hjælpe hinanden til at styrke forståelse.

I feedbacken er det igen centralt at være opmærksom på den symmetriske relation. Lige som den er grunden til, at studerende hellere vil høre underviseren end en medstuderende holde oplæg, er den også med til at besværliggøre både at give og modtage feedback. Det skal tages med i overvejelserne, når der vælges feedback-metode. Gives ordet helt frit risikerer debatten at flytte sig fra det faglige til det personlige, hvilket ikke er hensigtsmæssigt. De tre metoder, der her skal præsenteres, er: (1) gruppediskussion, (2) udfyldelse af skema og (3) fokuspunkter.

Den første metode til feedback er gruppediskussion. Efter oplægget opdeles de studerende i et antal grupper, som hver får et fokusområde. Det kan være spørgsmål stillet af den studerende, der holdt oplægget, eller af underviseren. Efter at have diskuteret i den afsatte tid samles der op i plenum. Fordelen ved denne form er, at det er en mindre konfrontatorisk dialog mellem den, der holdt oplægget, og resten af gruppen. Formen lader 
de studerende diskutere et emne inden for oplæggets rammer og giver dem derfor mulighed for at sætte egne ord på emnet.

Den anden feedbackmetode er at arbejde med et skema. Der er udviklet flere skemaer til feedback, men det er vigtigt at anvende et, der er anvendeligt i den givne faglige kontekst. Skemaet udleveres før oplægget, og efterfølgende kan tilhørerne enten selv eller i mindre grupper udfylde det, hvorefter det gennemgås i plenum. Elementer i et sådant skema kunne være:

- Hvad var påstanden i oplægget?

- Hvordan blev påstanden underbygget?

- Hvilket teoretisk fundament bygger påstanden på?

- Hvilke andre fundamenter kunne have været anvendt?

- Hvilke indvendinger blev fremført mod påstanden?

- Hvilke indvendinger kunne der i øvrigt være?

- Hvilke eksempler blev fremført?

- Hvilke andre eksempler kunne have været anvendt?

Disse spørgsmål har deres fundament i Toulmins argumentationsmodel (Toulmin, 2003). Formålet er både at lade tilhørerne afkode argumenterne i oplægget og at tænke videre selv og anvende $\mathrm{fx}$ anden teori eller andre eksempler. Fordelen ved denne form er, at den både regulerer tilhørerne og den, der holder oplægget, til at holde sig til faglig argumentation og til at være opmærksom på, hvordan forskellige metoder og teorier forholder sig til hinanden.

Den sidste form for feedback er at give grupper af tilhørere forskellige fokuspunkter at lytte med. Det kunne være de samme punkter som i skemaet eller nogle helt andre. Den helt enkle måde at bruge fokuspunkter på er at dele tilhørerne op i et grønt og et rødt hold og lade det grønne hold give feedback på alt det, der fungerer godt, og som er tydeligt i oplægget. Det røde hold skal omvendt fokusere på det, der kunne være mere præcist eller bedre i oplægget. Det er vigtigt at bede de studerende være meget konkrete i deres feedback, så det ikke alene bliver "det var fint nok" eller "det brød jeg mig bare ikke så meget om".

Gennem en eller flere feedbackmetoder øves hele holdets evne til at anvende fagets sprog, og det trænes i at lytte efter argumenter og forskelle i disse.

\section{Studenteroplæg som læringsaktivitet}

Som fremført ovenfor så er en struktureret tilgang til studenteroplæg med til at øge legitimiteten og udkommet af selv samme.

Selvom de studerende måtte have modstand mod at deltage i og holde oplæg for hinanden, er det en god måde at lade studerende arbejde med faget på uden at være under direkte bedømmelse. De elementer, man som underviser skal være opmærksom på, er:

- at legitimere aktiviteten som en del af faget

- $\quad$ at give den studerende, der holder oplæg, den bedste etosplatform

- $\quad$ at hjælpe oplægsholderen ved at være nærværende under oplægget

- at styre feedbacken, så den ikke bliver personlig men faglig.

Overholdes disse simple regler, trænes de studerende i at stå foran hinanden, i at tilrettelægge et oplæg og i at tale fagligt om deres stofområde. Fokus i denne tilgang er på at tale frit og at finde ind til hvordan et stofområde skal forstås og fortolkes. Som nævnt indledningsvist er det altså ikke afgørende, at oplægget er sprogligt perfekt, men at det er indholdsmæssigt interessant, og at de studerende sammen når en dybere forståelse af 
et emne, både som oplægsholdere og tilhørere. Men rammesætningen og ansvaret for et højt fagligt niveau er og bliver underviserens.

Linda Greve er forfatter til bøgerne Den gode præsentation (Samfundslitteratur 2010) samt Forandrende ledelseskommunikation (Samfundslitteratur 2012) sammen med Steen Hildebrandt. Desuden er hun medredaktør på antologien Entreprenørskabsundervisning (Aarhus Universitetsforlag 2011) sammen med Anne Kirketerp Linstad. Linda er en erfaren underviser og oplægsholder på kurser på både bachelor-, kandidat og ph.d.-niveau i præsentationsteknik og undervisningsmetode.

\section{Litteratur}

Bhatti, Y. \& Grøn, C. H. (2014). Det er det, de unge vil have. En analyse af studerendes præferencer i relation til undervisning. Dansk Universitetspæedagogisk Tidsskrift, 9(16), 96-112.

Ferrari, P. F., Gallese, V., Rizzolatti, G. \& Fogassi, L. (2003). Mirror neurons responding to the observation of ingestive and communicative mouth actions in the monkey ventral premotor cortex. European Journal of Neuroscience, 178),1703-1714.

Greve, L. (2011). Den gode præesentation: akademisk mundtlig fremstilling og personlig kommunikation. Frederiksberg: Samfundslitteratur.

Hickok, G. (2014). The Myth of Mirror Neurons: The Real Neuroscience of Communication and Cognition. New York: W. W. Norton \& Company.

Klentzin, J. C., Paladino, E. B., J ohnston, B \& Devine, C (2010). Pecha Kucha: using "lightning talk" in university instruction. Reference Services Review, 38(1), 158167. http://doi.org/10.1108/00907321011020798

Liu, N.-F. \& Carless, D. (2006). Peer feedback: the learning element of peer assessment. Teaching in Higher Education, 11(3), 279-290. http://doi.org/10.1080/13562510600680582

MacAlpine, J. M. K. (1999). I mproving and encouraging peer assessment of student presentations. Assessment \& Evaluation in Higher Education, 24(1), 15-25. http://doi.org/10.1080/0260293990240102

McCroskey, J. C. (2001). An Introduction to Rhetorical Communication. Boston: Allyn and Bacon.

Ong, W. J. (2013). Orality and Literacy: 30th Anniversary Edition. London: Routledge.

Raft, C. (1945). Taler-Teknik - Haandbog for Talere (3. ed.). København: C. A. Reitzels Forlag.

Toulmin, S. E. (2003). The Uses of Argument. Cambridge: Cambridge University Press. 


\section{Testbaseret optag til videregående uddannelser}

Maria Cecilie Vonsild, specialkonsulent, Syddansk Universitet

Agner Holmberg Schibler, AC-fuldmæegtig, Syddansk Universitet

Birgitta Wallstedt, leder af SDU Universitetspæadagogik, Syddansk Universitet

\section{Faglig artikel (bedømt af redaktionen)}

På Syddansk Universitet vil der som led i et nyt projekt blive indfort nye optagelsesprocedurer i forbindelse med bacheloroptaget i 2017. Allerede nu er over 50 bacheloruddannelser på tværs af fakulteterne i færd med at ændre deres nuværende optagelsesprocedurer til i højere grad at anvende tests og samtaler, enten i form af optagelsesprover i kvote 2 eller som adgangsprover, der kan sidestilles med et karakterkrav.

I artiklen beskrives anvendeligheden af skriftlige/mundtlige tests og motiverede ansøgninger samt de lovgivningsmæssige muligheder for indførelse af optagelses- og adgangsprover på de danske universiteter. Der gives eksempler på typer af optagelsestests, der anvendes på universiteter i udlandet, ligesom der præsenteres konkrete eksempler på testindhold og resultater fra den særlige optagelsesprocedure i kvote 2 på Det Sundhedsvidenskabelige Fakultet på SDU. Erfaringer fra andre uddannelsesinstitutioner inddrages også, danske såvel som internationale.

\section{Indledning}

På Syddansk Universitet (SDU) vil der som led i et nyt optagelsesprojekt blive indført optagelses-og adgangsprøver med anvendelse af forskellige typer tests i forbindelse med bacheloroptaget fra 2017. Målet er, at mindst $25 \%$ af de studerende på hvert fakultet skal optages enten på baggrund af adgangsprøver som en del af adgangskravene, eller i form af optagelsesprøver i kvote 2.

Projektet skal udvikle en fælles model - SDU-modellen - for organiseringen af optagelsesog adgangsprøverne. Her har bacheloruddannelserne mulighed for at vælge mellem følgende:

1) fagspecifik test eller 2) både uniTEST og fagspecifik test:

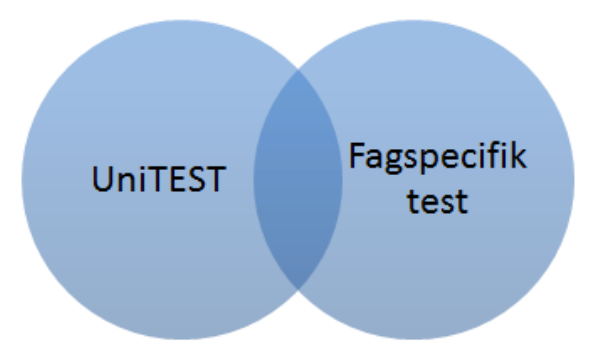


SDU modellen skal leve op til fire grundlæggende kvalitetskriterier. Testene skal være:

1. Valide - Testene skal måle det, som vi ønsker at måle (viden, færdigheder, kompetencer).

2. Pålidelige - Testene skal være retfærdige og konsistente.

3. Acceptable - Testene skal både for ansøgerne og omgivelserne opleves som acceptable.

4. Gennemførlige - Testene skal være praktisk gennemførlige, administrativt effektive og baseret på overvejelser over ressourceanvendelse og økonomi.

Baggrunden for denne artikel er, at der i forbindelse med SDU's nye optagelsesprojekt er opstået et behov for at få præciseret rammerne for de eksisterende muligheder i optagelsessystemet og for hvilke overvejelser, der skal gøres, forud for planlægningen af nye optagelsesprocedurer: Hvad skal testene indeholde, hvilke kompetencer ønsker man at måle, og hvilke tests er bedst egnede til hvilke fagområder?

Udover at efterkomme et lokalt behov for en fælles forståelse for rammer, terminologi og indhold modtager SDU i stigende grad henvendelser fra andre uddannelsesinstitutioner, som ønsker at videreudvikle deres nuværende optagelsessystemer til også at se på andre parametre end kun det adgangsgivende karaktergennemsnit.

Formålet er derfor indledningsvist at beskrive, hvilke muligheder de danske universiteter har for at indføre adgangs- og optagelsesprøver inden for gældende lovgivning, samt præsentere eksempler på forskellige testtyper og på, hvordan de anvendes til optagelse af studerende til videregående uddannelser rundt om i verden. På baggrund heraf vil vi beskæftige os med indholdet af forskellige testtyper (skriftlige og mundtlige tests, motiverede ansøgninger), samt præsentere eksempler på SDU's resultater med anvendelse af særlige optagelsesprocedurer på de sundhedsvidenskabelige uddannelser. Desuden vil erfaringer fra den danske læreruddannelse samt internationale erfaringer blive inddraget.

\section{Eksisterende muligheder i det danske optagelsessystem}

I den gældende bacheloradgangsbekendtgørelse (BEK nr. 257 af 18/3/2015) ${ }^{1}$, beskrives de muligheder, der findes i dag for at indføre testbaseret optag:

1. Karakterkrav samt anvendelse af adgangsprøver, der kan sidestilles med karakterkrav (§5).

2. Kvotefordeling samt anvendelse af samtaler og optagelsesprøver i kvote 2 (§ 23).

${ }^{1}$ https://www.retsinformation.dk/forms/R0710.aspx?id=168839 


\section{Ad. 1.: Karakterkrav}

Efter $\S 5$ kan et universitet kræve, at den adgangsgivende eksamen er gennemført med et bestemt eksamensgennemsnit som minimum, eller at enkelte fag er bestået med en bestemt minimumskarakter højere end 02. Fastsættelse af karakterkrav skal varsles med mindst 2 år, før de får virkning.

Indføres der karakterkrav, vil karakterkravet være en del af adgangskravet. Det er derfor ikke muligt at fastsætte et karakterkrav for kvote 1 ansøgere, som ikke skal gælde for kvote 2 ansøgere. Karakterkravet gælder altså for både kvote 1 og kvote 2 ansøgere.

Ved indførelsen af stk. 2. får universiteterne nu mulighed for at indføre en adgangsprøve som dokumenterer tilsvarende kvalifikationer. Dette er nyt i bacheloradgangsbekendtgørelsen fra marts 2015. Ligesom karakterkravet er en del af adgangskravene, vil adgangsprøven også være en del af adgangskravene. Ansøgere, der ikke opfylder karakterkravet, kan hermed stadig komme i betragtning til en studieplads, hvis de består adgangsprøven på et niveau, som universitetet skønner kan sidestilles med det fastsatte karakterkrav. Adgangsprøven skal opfattes som en erstatning for manglende opfyldelse af et karakterkrav.

\section{Ad. 2.: Kvote 2}

Er der flere ansøgere end studiepladser på bacheloruddannelser med adgangsbegrænsning, opdeles pladserne i kvote 1 og 2. Styrelsen fastsætter hvert år kvoternes størrelse efter indstilling fra universiteterne. Et universitets ønske imødekommes almindeligvis, hvis det ikke strider imod visse rammer herfor ( $\mathrm{fx}$ må studiepladserne ikke fordeles med $100 \%$ i kvote 1 og 0\% i kvote 2). Det er således muligt at introducere en større kvote 2 og/eller øge anvendelsen af optagelsesprøver på en række bacheloruddannelser.

Studiepladserne i kvote 2 tildeles efter en konkret vurdering af ansøgerne på baggrund af objektive, faglige kriterier fastsat af det enkelte universitet. I vurderingen kan der indgå optagelsesprøver, samtaler m.v.

Der kan desuden indgå bestemte fagsnit (karakterer i udvalgte fag) i kvote 2: man kan godt lægge vægt på et bestemt fag, men fagsnittet må ikke stå alene - det skal anvendes i kombination med andre kriterier for at sikre, at der foretages en konkret vurdering af hver enkelt ansøger.

Endelig kan Styrelsen for Videregående Uddannelser godkende, at universitetet på visse bacheloruddannelser anvender et andet optagelsessystem end kvotesystemet (§13, stk. 3). Dette er fx tilfældet på bacheloruddannelserne i J ournalistik.

\section{Særligt for Sundhedsvidenskab:}

På Det Sundhedsvidenskabelige Fakultet har man siden 2008 haft særlig tilladelse til at indføre et karakterkrav som en del af optagelsesproceduren i kvote 2.

Følgende bliver inviteret til test:

Alle ansøgere med et gennemsnit på 6,0 eller derover efter 7-trins skalaen.

Årets dimittender, hvis de opfylder de specifikke adgangskrav for den pågældende bacheloruddannelse. 
Tilbud om studieplads vil dog være betinget af, at ansøgeren opfylder de specifikke adgangskrav til den ansøgte uddannelse senest $d$. 5. juli i optagelsesåret, og at årets dimittender har opnået et gennemsnit fra den adgangsgivende eksamen på mindst 6,0 efter 7-trins skalaen

Hvis andre bacheloruddannelser ønsker at gøre det samme, nemlig sortere ansøgere fra på baggrund af et karakterkrav gældende for kvote 2 alene, skal der indhentes særlig tilladelse hos Styrelsen for Videregående Uddannelser.

\section{Adgangsprøver versus optagelsesprøver}

Det er vigtigt at skelne mellem, om en optagelsesprocedure anvender en adgangsprøve eller en optagelsesprøve, idet der juridisk set er forskel herpå: En optagelsesprøve har til formål at udvælge studerende blandt ansøgere, der alle opfylder adgangskravene. En adgangsprøve derimod er en del af adgangskravene til uddannelsen, idet prøven skal sidestilles med og dermed erstatter karakterkravet til uddannelsen.

\section{Typer af optagelsestests der anvendes på universiteter i udlandet - et over- blik:}

Optagelsestests anvendes i udbredt grad på universiteter verden over, enten som det eneste adgangskrav, eller som supplement til karakterer opnået i en gymnasial uddannelse.

Tests kan være enten generelle eller fagspecifikke og kan anvendes som det eneste adgangsgrundlag eller i kombinationer med hinanden eller med eksamensresultater fra den adgangsgivende eksamen.

Det svenske optagelsessystem har således forskellige veje ind til en videregående uddannelse. Enten vurderes ansøgerne på baggrund af deres karaktergennemsnit fra den adgangsgivende eksamen, eller de vurderes på baggrund af deres resultat fra Högskoleprovet $^{2}$ - en generel adgangstest i MCQ-format. Som en tredje mulighed kan universiteterne anvende andre, selvvalgte optagelsesprocedurer, som fx samtaler eller andre testtyper.

I visse lande, fx i USA og Kina, indgår en fælles, generel adgangstest som et overordnet adgangskrav, hvor ansøgerne skal gennemføre en adgangsprøve som forudsætning for at komme i betragtning til en studieplads. I USA anvendes $\mathrm{fx}$ en generel test for vurdering af akademiske kompetencer (Scholastic Aptitude Test SAT ${ }^{3}$ ) som adgangsprøve til mange forskellige uddannelsesområder.

Tests kan også være fagspecifikke. Særligt inden for det sundhedsvidenskabelige område er det almindeligt at anvende tests til at vurdere kompetencer og/eller personlige egenskaber, der matcher en specifik uddannelse, fx dyrlæge eller læge.

Nedenstående tabeller viser eksempler på henholdsvis generelle tests (tabel 1) og fagspecifikke tests (tabel 2):

\footnotetext{
${ }^{2}$ http://studera.nu/hogskoleprov/det-viktigaste-om-hogskoleprovet/

${ }^{3}$ https://sat.collegeboard.org/home
} 
Tabel 1: Eksempler på generelle tests

\begin{tabular}{|c|c|c|c|c|}
\hline Testtype & I ndhold & Land & Optagelsessystem & \\
\hline \multirow[t]{3}{*}{ uniTEST (ACER) } & \multirow[t]{3}{*}{$\begin{array}{l}\text { Kritisk, kvantitativt og sprog- } \\
\text { ligt ræsonnement }\end{array}$} & Australien & \multirow[t]{3}{*}{$\begin{array}{l}\text { Supplement til formelle ad- } \\
\text { gangskrav }\end{array}$} & Udvalgte universiteter \\
\hline & & DK & & Udvalgte universiteter \\
\hline & & UK & & Udvalgte universiteter \\
\hline $\begin{array}{l}\text { Högskoleprovet } \\
\text { (MCQ) }\end{array}$ & $\begin{array}{l}\text { Kvantitativt ræsonnement og } \\
\text { matematisk problemløsning } \\
\text { Verbal del - ord og læsefor- } \\
\text { ståelse (svensk og engelsk) }\end{array}$ & Sverige & $\begin{array}{l}\text { Mindst } 1 / 3 \text { af alle studerende } \\
\text { på alle universiteter i Sverige } \\
\text { optages på baggrund af } \\
\text { Högskoleprovet }\end{array}$ & Nationalt optagelsessystem \\
\hline \multirow[t]{2}{*}{$\begin{array}{l}\text { Thinking Skills } \text { Asses- } \\
\text { sment (MCQ) }\end{array}$} & \multirow[t]{2}{*}{$\begin{array}{l}\text { Kritisk tænkning og problem- } \\
\text { løsning }\end{array}$} & UK & \multirow[t]{2}{*}{$\begin{array}{l}\text { Supplement til fagspecifikke } \\
\text { testformer }\end{array}$} & \multirow[t]{2}{*}{ Udvalgte universiteter } \\
\hline & & Holland & & \\
\hline $\begin{array}{l}\text { Scholastic Aptitude Test } \\
\text { (MCQ) }\end{array}$ & $\begin{array}{l}\text { Kritisk tænkning og problem- } \\
\text { løsning } \\
\text { Baseret på High School Curri- } \\
\text { culum }\end{array}$ & USA & $\begin{array}{l}\text { Anvendes også i kombination } \\
\text { med SAT Subject Tests }\end{array}$ & $\begin{array}{l}\text { Udvalgte universiteter, men } \\
\text { anvendes bredt på tværs af USA's } \\
\text { stater }\end{array}$ \\
\hline Gaokao (Essay) & $\begin{array}{l}\text { Baseret på High School Cur- } \\
\text { riculum }\end{array}$ & Kina & $\begin{array}{l}\text { Anvendes som en universel } \\
\text { adgangstest }\end{array}$ & Nationalt optagelsessystem \\
\hline
\end{tabular}


Tabel 2: Eksempler på fagspecifikke tests

\begin{tabular}{|c|c|c|c|c|}
\hline Fagspecifik tests indenfor & Testtype & Land & Optagelsessystem & \\
\hline \multirow[t]{9}{*}{ Sundhedsvidenskab } & \multirow[t]{3}{*}{$\begin{array}{l}\text { Medical College Admission test } \\
\text { (MCAT) }\end{array}$} & USA & $\begin{array}{l}\text { Anvendes som en universel } \\
\text { adgangstest }\end{array}$ & Alle medicinuddannelser \\
\hline & & Canada & $\begin{array}{l}\text { Supplement til karaktergen- } \\
\text { nemsnit og andre testformer }\end{array}$ & Udvalgte universiteter \\
\hline & & Australien & $\begin{array}{l}\text { Supplement til karaktergen- } \\
\text { nemsnit og andre testformer }\end{array}$ & Udvalgte universiteter \\
\hline & $\begin{array}{l}\text { Undergraduate Medical Admis- } \\
\text { sions test (UMAT) }\end{array}$ & Australien & $\begin{array}{l}\text { Anvendes som en universel } \\
\text { adgangstest }\end{array}$ & Alle medicinuddannelser \\
\hline & \multirow[t]{4}{*}{ Multiple Mini Interview (MMI) } & Canada & $\begin{array}{l}\text { Supplement til karaktergen- } \\
\text { nemsnit og andre testformer }\end{array}$ & Udvalgte universiteter \\
\hline & & $\overline{U K}$ & $\begin{array}{l}\text { Supplement til karaktergen- } \\
\text { nemsnit og andre testformer }\end{array}$ & Udvalgte universiteter \\
\hline & & DK & $\begin{array}{l}\text { Supplement til adgangsgiven- } \\
\text { de karaktergennemsnit og } \\
\text { uniTEST }\end{array}$ & $\begin{array}{l}\text { Syddansk Universitet siden } 2008 \\
\text { Århus Universitet fra } 2016\end{array}$ \\
\hline & & Australien & $\begin{array}{l}\text { Supplement til karaktergen- } \\
\text { nemsnit og andre testformer }\end{array}$ & Udvalgte universiteter \\
\hline & $\begin{array}{lcc}\text { United } & \text { Kingdom } & \text { Clinical } \\
\text { Aptitude test (UKCAT) } & \end{array}$ & UK & $\begin{array}{l}\text { Supplement til karaktergen- } \\
\text { nemsnit og andre testformer }\end{array}$ & Udvalgte universiteter \\
\hline \multirow[t]{3}{*}{ Jura } & $\begin{array}{l}\text { Law School Admission Test } \\
\text { (LSAT) }\end{array}$ & USA & $\begin{array}{l}\text { Supplement til formelle ad- } \\
\text { gangskrav }\end{array}$ & Udvalgte universiteter \\
\hline & $\begin{array}{l}\text { Law School Admission Test } \\
\text { (LSAT) }\end{array}$ & Canada & $\begin{array}{l}\text { Supplement til formelle ad- } \\
\text { gangskrav }\end{array}$ & Udvalgte universiteter \\
\hline & $\begin{array}{l}\text { National Admissions Test for } \\
\text { Law (LNAT) }\end{array}$ & UK & $\begin{array}{l}\text { Anvendes som en universel } \\
\text { adgangstest }\end{array}$ & Udvalgte universiteter \\
\hline Historie & History Aptitude Test (HAP) & UK & $\begin{array}{l}\text { Supplement til formelle ad- } \\
\text { gangskrav }\end{array}$ & Oxford University \\
\hline Ingeniør & ATN Engineering Test (ACER) & $\begin{array}{l}\text { Australien } \\
\text { (ATNEST) }\end{array}$ & $\begin{array}{l}\text { Anvendes til internationale } \\
\text { ansøgere, æeldre ansøgere, } \\
\text { ansøgere som ikke opfylder de } \\
\text { formelle adgangskrav }\end{array}$ & University og South Australia \\
\hline Matematik & Sixth Term Examination paper & UK & $\begin{array}{l}\text { Supplement til formelle ad- } \\
\text { gangskrav }\end{array}$ & Udvalgte universiteter \\
\hline
\end{tabular}


Fælles for mange af de testtyper som er angivet i tabellerne er, at de er designet til at vurdere ansøgemes evner og studieegnethed. I de fagspecifikke tests er indholdet kontekstvalideret $\mathrm{i}$ forhold til fagområdet. Testene måler $\mathrm{i}$ overvejende grad potentiale og evner (aptitude) for at tilegne sig viden og færdigheder, men de kan også teste færdigheder og viden, som allerede er tilegnet (achievement).

Et eksempel på en achievement test er den kinesiske Gaokao. ${ }^{4}$ UniTEST ${ }^{5}$ er et eksempel på en aptitude test (for at kunne ræsonnere sig frem til det rigtige svar kræves dog allerede tilegnet viden $\mathrm{fx}$ at kunne læse og forstå et koordinatsystem), mens det svenske Högskoleprov indeholder elementer af begge dele. Det er således vanskeligt at opdele de anvendte tests i enten rene aptitude eller rene achievement tests.
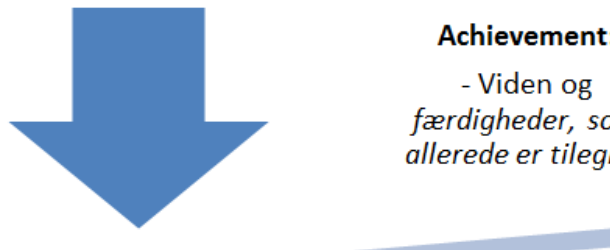

- Viden og færdigheder, som allerede er tilegnet

\section{Optagelsesprocedurers indhold:}

I de følgende afsnit beskrives udvalgte erfaringer og resultater med anvendelse af optagelsesprocedurer, hvori der indgår skriftlige og mundtlige tests samt motiverede ansøgninger:

\section{Skriftlige tests}

En uniTEST har været anvendt siden 2008 på Det Sundhedsvidenskabelige Fakultet, SDU som præselektionstest til udvælgelse af de ansøgere, der går videre til den sidste del af optagelsesproceduren (Multiple Mini Interviews).

UniTEST er udviklet i samarbejde mellem the Australian Council for Educational Research (ACER) og Cambridge Assessment. ACER har over 80 års erfaring i udvikling af adgangsprøver. Testen er en multiple choice questionnaire (MCQ) test der består af 90 spørgsmål og skal gennemføres på 2,5 time. Den er designet til at måle generel studieegnethed inden for 3 udvalgte domæner: Kritisk, kvantitativt og sprogligt ræsonnement.

\section{SDU's erfaringer:}

UniTEST har fungeret med høj grad af reliabilitet (intern konsistens) med en Cronbachs Alpha koefficient på gennemsnitligt 0,86 i de år, den har været anvendt på Sundhedsvidenskab (2008-14). Af graferne nedenfor ses, at uniTEST'en ikke korrelerer med den adgangsgivende kvotient. Disse resultater har været konsistente henover årerne og på tværs af studieretningerne.

\footnotetext{
${ }^{4}$ http://www.slate.com/articles/news and politics/dispatches/2008/06/chinas sat.html

${ }^{5}$ http://unitest.acer.edu.au/
} 

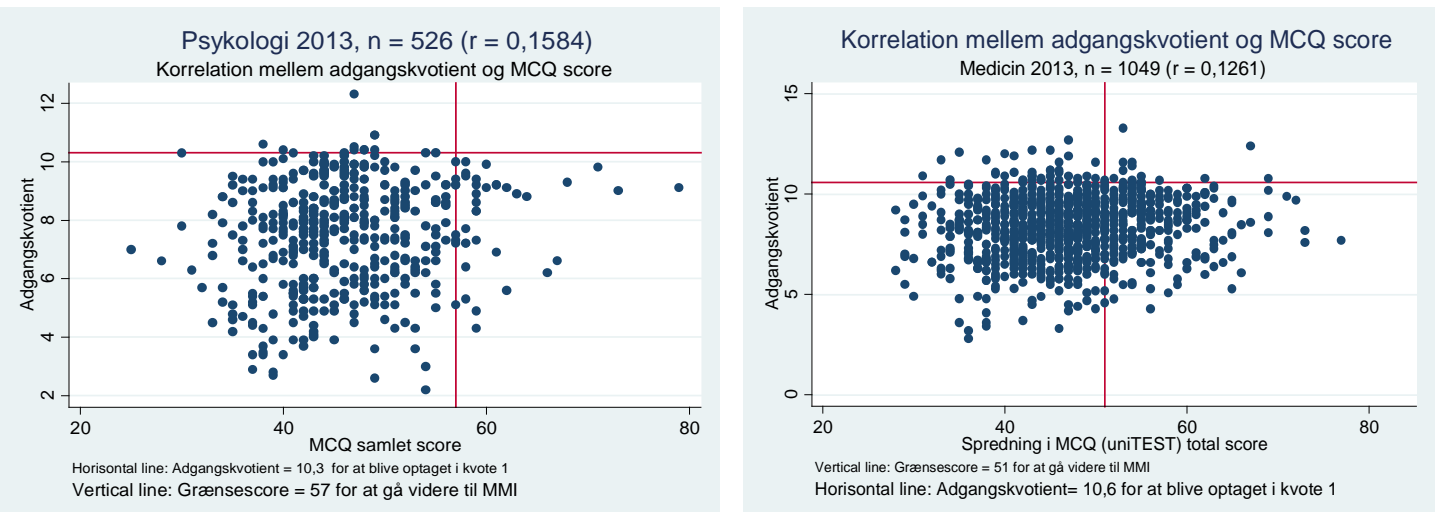

Figur 1: Sammenhængen mellem den adgangsgivende kvotient for ansøgere til henholdsvis medicin- og psykologistudiet og opnået resultat til uniTEST

\section{Effekten af at være udvalgt i kvote 2 kontra optaget i kvote 1}

Der er endnu ikke foretaget separate analyser af uniTESTens prædiktive validitet i forhold til frafald eller andre parametre for akademisk præstation, som fx beståelsesprocent ved førsteårsprøven. Derimod har SDU igennem de sidste 4 år fortaget systematiske evalueringer af sammenhængen mellem at være optaget i kvote 1 eller udvalgt i kvote 2. Evalueringen for perioden 2008-13 viser, at det at være udvalgt i kvote 2 medfører et signifikant mindre frafald efter første og andet studieår og en signifikant højere beståelsesprocent ved førsteårsprøven sammenlignet med de kvote 1 optagne (StudieserviceAnalyse, 2015).

Konklusionen på disse resultater er, at uniTEST bidrager til at måle studieegnethed på en anden måde, end karaktergennemsnittet gør. Dels er der ingen sammenhæng mellem karaktergennemsnittet fra den adgangsgivende eksamen og det opnåede resultat til uniTEST (figur 1); dels klarer de studerende, der er udvalgt i kvote 2, sig mindst lige så godt, eller endnu bedre, end de studerende, der er optaget i kvote 1.

\section{En second chance}

Erfaringerne fra SDU viser også, at anvendelsen af uniTEST har betydning for hvilke ansøgere, der bliver optaget. Af grafen for Psykologi (figur 1) ses, at grænsekvotienten for optagelse i kvote 1 i 2013 var på 10,3 (den vandrette, røde linje), mens grænsescoren for at gå videre til Multiple Mini Interviews var 57 (den lodrette, røde linje). Alle de ansøgere, der befinder sig under den vandrette og til højre for den lodrette linje, ville slet ikke være kommet i betragtning til en studieplads, hvis karaktergennemsnittet fra den adgangsgivende eksamen havde været det eneste adgangskrav. Godt halvdelen af ansøgerne (25) i denne gruppe endte med at få tilbudt en studieplads i kvote 2. Samme billede tegner sig for Medicin, hvor der blev optaget ca. 150 studerende i kvote 2 ud af de ca. 300 der gik videre efter uniTEST. Man kan altså med god ret tale om, at denne testform giver en second chance til de ansøgere, som ikke har tilstrækkeligt høje gennemsnit til at komme ind via kvote 1.

\section{Flere mænd bliver optaget på Medicin}

I nedenstående figur 2 illustreres udvælgelsesproceduren i kvote 2 optagelsen til Medicinstudiet for 2015. Processen består af to runder, hvor første runde er deltagelse i MCQ testen (uniTEST) og anden runde er MMl (Multiple Mini Interview). Ca. 1400 ansøgere deltog i 1 . runde og ca. 300 gik videre til 2 . runde, hvorefter halvdelen fik tilbudt en stu- 
dieplads. De blå og røde søjler viser, at der var væsentligt flere kvindelige end mandlige deltagere i 1. runde (MCQ testen), men fordi mændene klarede sig bedre, betød dette en næsten ligelig kønsfordeling i 2. runde, hvor begge køn klarede sig lige godt.

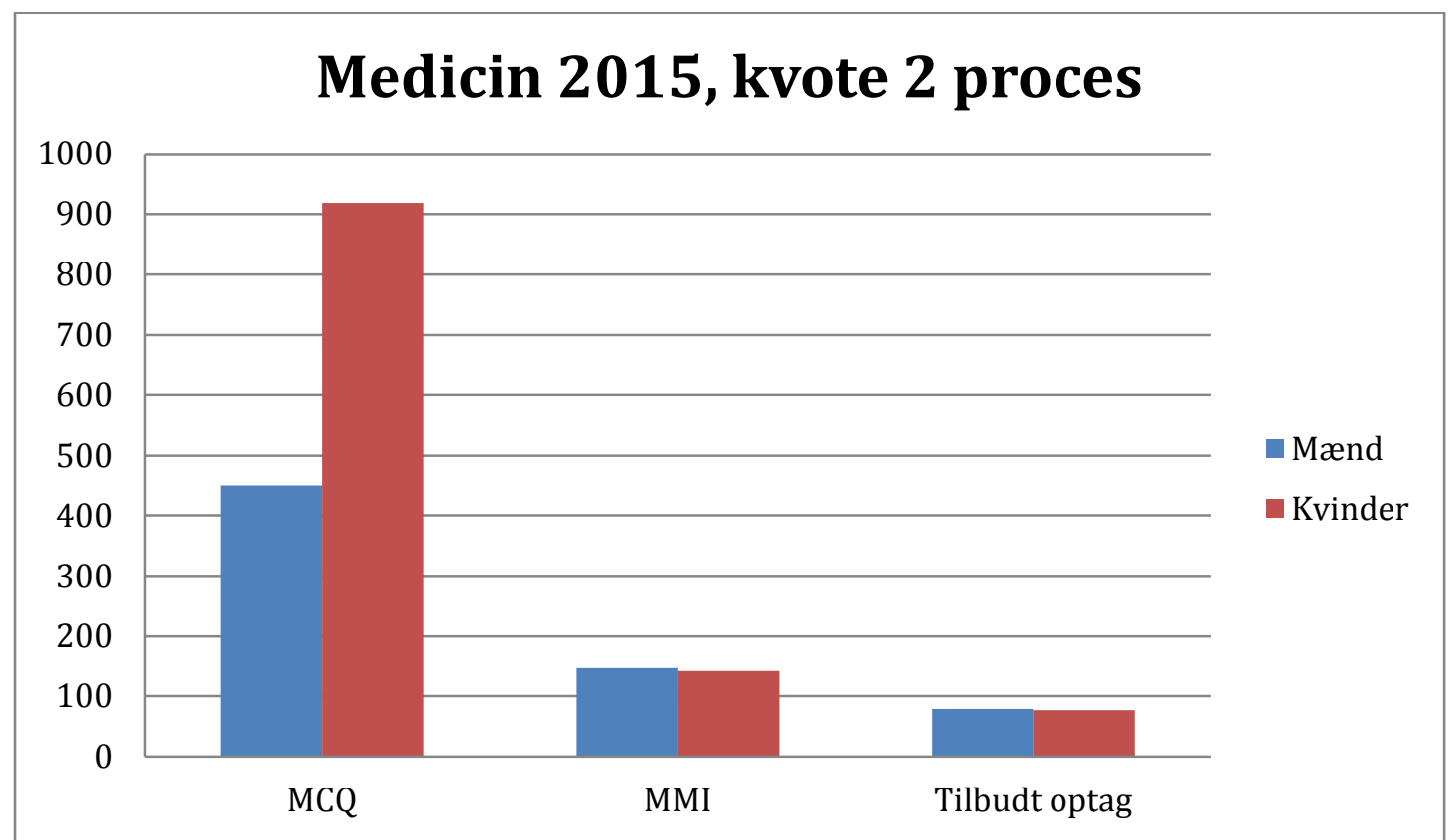

Figur 2: Optagelsesproceduren i kvote 2 til medicinstudiet på Syddansk Universitet i 2015

\section{Selektionseffekt}

Til MCQ testen i år havde i alt 2918 ansøgere til Psykologi, Folkesundhedsvidenskab, Medicin og Klinisk Biomekanik tilmeldt sig via SDU's digitale system. Men på dagen for testens afholdelse mødte kun 2230 op, altså en udeblivelsesprocent på 23,6\%.

En mulig forklaring på udeblivelse, som vi har undersøgt, er prioritet af uddannelse. For en ansøger, der har en uddannelse som 1. prioritet, viser fig. 3, at sandsynligheden for at vedkommende møder op til test er $>80 \%(0,8)$. Har ansøgeren derimod uddannelsen som 4. prioritet, er sandsynligheden for fremmøde $60 \%$ (figur 3 ).

Der synes altså at være en direkte sammenhæng mellem sandsynligheden for fremmøde og ansøgernes prioritet. 


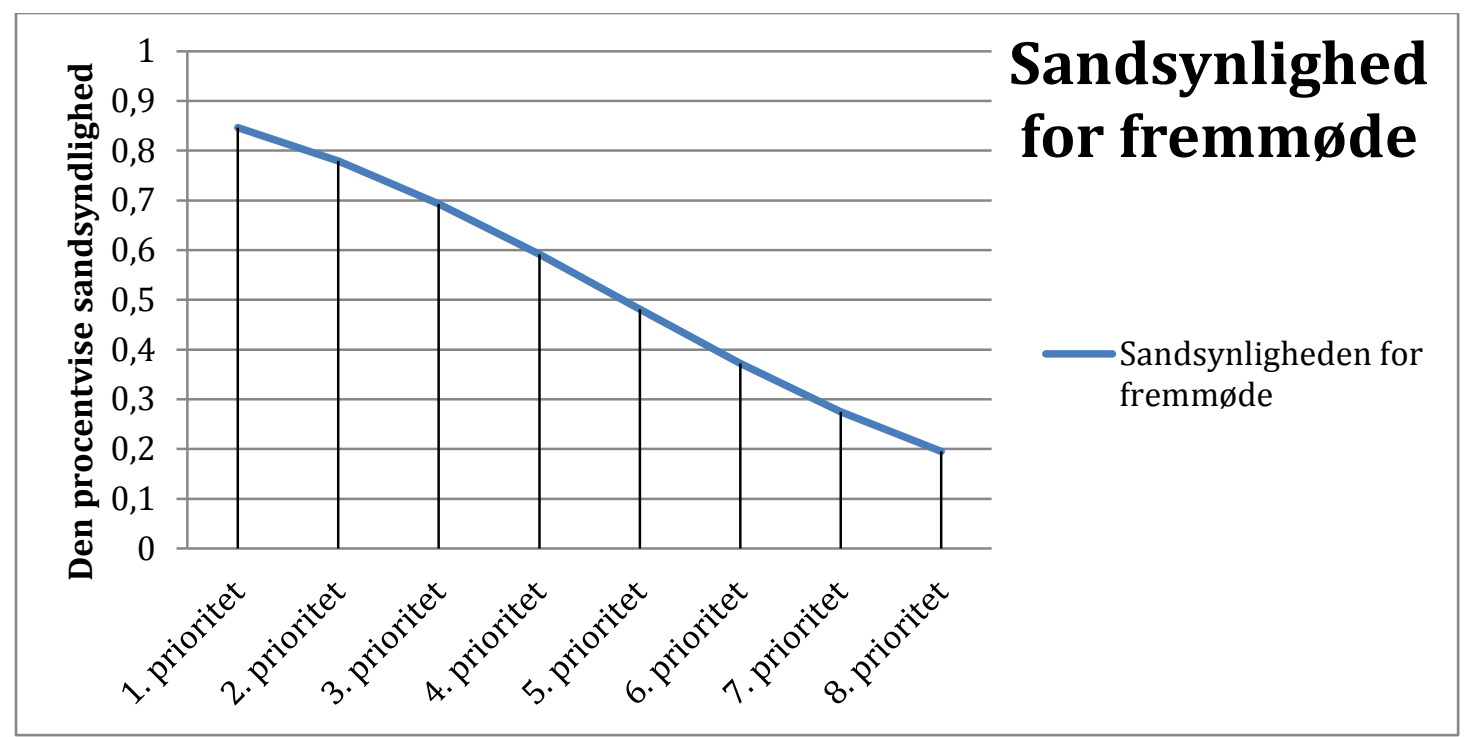

Figur 3: Sandsynligheden for at møde op til test vs. prioritet af uddannelse

På Læreruddannelsen, hvor man i 2013 indførte testbaseret optag, skal ansøgerne selv tilmelde sig optagelsesprøven. Op til 22\% tilmelder sig ikke, hvilket indebærer en markant selvselektion forud for selve optagelsesprøven (Styrelsen for Videregående Uddannelser, 2015). Det at skulle booke et møde, eller møde op til en test, er altså i sig selv en måde at sortere blandt ansøgere, som måske ikke er tilstrækkeligt motiverede for den uddannelse, de har søgt ind på.

\section{Internationale erfaringer}

UniTEST er valideret på australske studerende på seks forskellige universiteter. I en evaluering af testens prædiktive validitet i forhold til studiesucces fandt man, at resultat opnået ved uniTEST forklarede mere variation i opnåede karakterer på universitetet efter et års studietid end karaktergennemsnit fra det, der svarer til en gymnasial eksamen ( 12. års karaktergennemsnit). Yderligere fandt man, at kombinationen af 12. års karaktergennemsnit og UniTEST resultatscore, viste en stærkere sammenhæng med opnåede karakterer på universitetet end 12. års karaktergennemsnit eller uniTEST resultat alene (Coates et al., 2010).

\section{Mundtlige tests}

Et eksempel på en evidensbaseret mundtlig testtype er de såkaldte Multiple Mini Interviews (MMI), som er udviklet på Michael DeGroote School of Medicin på McMaster University i Canada (Eva et al., 2004) og sidenhen anvendt som optagelsesprocedure på en lang række medicinuddannelser (Brownell et al., 2007; Harris \& Owen, 2007; Hecker et al., 2009). Et MMI-forløb består typisk af 6 - 8 stationer, hvor hver ansøger starter samtidig med de andre ansøgere, men ved hver deres station. Interviewet varer 8-10 minutter, og når interviewet er slut ved én station, roterer ansøgerne videre til den næste station. Der er én interviewer ved hver station. Styrken ved anvendelse af denne type af strukturerede optagelsessamtaler er kontekstuafhængighed, fordi bedømmelsen af én færdighed ved én MMI-station ikke påvirker den næste MMI-station, og at der er mange bedømmere, hvilket øger reliabiliteten (Eva et al., 2004).

Indholdsvalideringen af MMl foretages ved hjælp af et uddannelsesspecifikt blueprint, hvor der genereres en matrix for de kriterier, ansøgerne skal bedømmes på ved de en- 
kelte samtalestationer. Blueprintet er udarbejdet af et fagligt ekspertpanel med det primære formål at sikre det optimale match mellem den studerende og uddannelsen.

\section{Internationale erfaringer}

Forskningen viser, at MMI-testen har en høj reliabilitet og er prædiktiv i forhold til kliniske færdigheder og præstation ved den afsluttende embedseksamen, hvor kliniske og kommunikative færdigheder testes (Eva et al., 2009; LeMay et al., 2007; Reiter et al., 2007; Roberts et al., 2009).

\section{Motiverede ansøgninger}

En anden måde at udvælge ansøgere på er brugen af motiverede ansøgninger i kvote 2 . Denne metode er temmelig udbredt, både udenlands og herhjemme.

Måden, hvorpå motiverede ansøgninger indgår i optagelsesproceduren, er meget forskellig. Typisk anvendes de som en del af en kvote 2 procedure som supplement til karakterkrav i særligt relevante fagkombinationer. På nogle uddannelser er den motiverede ansøgning et formelt krav i ansøgningen og anvendes som præselektion til at udvælge de ansøgere, der skal gå videre til det næste led i optagelsesproceduren.

Nogle uddannelser, fx J ournalistuddannelsen i Århus, anvender den motiverede ansøgning i en udvælgelsessamtale med de ansøgere, der har deltaget i den første del af optagelsesprøven, men som ikke fik point nok til at blive optaget direkte.

\section{SDU's erfaringer}

På Det Sundhedsvidenskabelige Fakultet anvendte man i årerne 2002-07 motiverede ansøgninger som præselektion til Klinisk Biomekanik, Medicin og Idræt \& Sundhed. Den motiverede ansøgning blev indsendt sammen med den formelle kvote 2 ansøgning og vurderet af to bedømmere. Det viste sig dog, at der var væsentlige problemer ved anvendelse af denne metode: I forhold til validitet har brugen af motiverede ansøgninger grundlæggende det problem, at der ingen sikkerhed er for, at ansøgningen er skrevet af ansøgeren selv. Den kunne lige så vel være skrevet/redigeret af andre, eller direkte fabrikeret af en spøgelsesskribent. Så længe en motiveret ansøgning ikke skrives under kontrollerede forhold, har bedømmerne ingen garanti for, at ansøgningen er skrevet af rette vedkommende, og dermed er validiteten særdeles tvivlsom.

Reproducerbarheden af bedømmelsen af de motiverede ansøgninger blev undersøgt i en ph.d.-afhandling om optagelsesproceduren på Sundhedsvidenskab i 2007. Resultatet viste så høj grad af uoverensstemmelse i bedømmelsen af ansøgningerne (foretaget af to bedømmere), at resultatet for generaliserbarhed $(G=0,10)$ lå væsentligt under den acceptable grænse. Til sammenligning blev der fundet god generaliserbarhed ved anvendelsen af strukturerede samtaler og for kombinationen af vurdering af kvalifikationer, samtale og paratvidentest ( $G=0,82$ ) (O'Neill et al., 2009).

Derudover kan det være en særdeles administrativ tung og ressourcekrævende opgave at læse motiverede ansøgninger igennem, især hvis der skal være mindst to bedømmere per ansøgning.

Til trods for den meget udbredte anvendelse af motiverede ansøgninger, findes der kun ganske sparsom forskning i brugen af samme, der understøtter, at dette er en pålidelig og valid måde at udvælge og frasortere kommende studerende på (Ferguson et. al., 2000; Salvatori et al., 2001; Oosterveld \& ten Cate, 2004; Wouters et. al., 2014). 


\section{Konklusion}

Inden for rammerne af gæeldende lovgivning har universiteterne følgende muligheder for at indføre optagelsesprocedurer, hvor ansøgere kan blive vurderet på andre parametre end karakterer:

- $\quad$ Adgangsprøver, som en del af adgangskravene, hvor resultatet af prøven erstatter et givent minimumskarakterkrav.

- $\quad$ Optagelsesprøver i kvote 2, hvor formålet er at udvælge blandt ansøgere, der alle opfylder de formelle adgangskrav.

- $\quad$ Vælge et andet optagelsessystem end kvotesystemet (kræver dog særlig tilladelse fra Styrelsen for Videregående Uddannelser).

Anvendelsen af testbaseret optag er særdeles udbredt rundt om i verden. Her er tests typisk generelle eller fagspecifikke, og de anvendes til at vurdere studieegnethed. Indholdet kan enten være baseret på vurdering af generelle eller specifikke færdigheder, der allerede er indlært (achievement), eller de kan være designet til at vurdere potentiale og evner til at kunne tilegne sig generelle eller specifikke faglige færdigheder (aptitude).

Når en testtype skal vælges, er det derfor vigtigt at gøre sig overvejelser omkring, hvad det er, testen skal kunne måle:

- $\quad$ Er det generelle/specifikke kompetencer uddannelsen kræver - eller en kombination af begge dele?

- $\quad$ Er det vigtigt, at ansøgeren allerede har en tilegnet færdighed, eller er det evnerne til at kunne tilegne sig de kompetencer som uddannelsen kræver?

Når disse tanker er gjort, skal der vælges en eller flere tests, der måler det (viden, færdigheder, kompetencer), som uddannelsen ønsker at måle. I denne artikel er vi gået særligt i dybden med indholdet og anvendeligheden af følgende testtyper:

1) Skriftlig test: uniTEST, en aptitude test, kan anvendes til at vurdere generel studieegnethed indenfor tre overordnede domæner: kritisk, kvantitativt og sprogligt ræsonnement. Testen fungerer med høj grad af reliabilitet og er på SDU blevet anvendt til at teste op til 3000 ansøgere på én og samme dag.

2) Mundtlig test: Multiple Mini Interview, kan anvendes som en fagspecifik test til at matche kompetencer, motivation, og personlige egenskaber specifikt til en uddannelses kompetenceprofil. Interviewformatet fungerer med rimelig grad af pålidelighed, og internationale studier har dokumenteret, at denne testform prædikterer senere studiesucces.

3) Motiverede ansøgninger: Tvivlsom validitet, reproducerbarhed og gennemførlighed medfører oftest manglende acceptabilitet blandt bedømmere, ledere og andre primære interessenter. Hvordan motiverede ansøgninger anvendes i en optagelsesprocedure bør derfor overvejes nøje. Motiverede ansøgninger kan vise sig anvendelige og informative, hvis de anvendes som udgangspunkt for en optagelsessamtale, mens metoden er kontroversiel, hvis den anvendes som det eneste parameter til at sortere ansøgere fra. 
I denne artikel har vi valgt at beskæftige os med de lovgivningsmæssige rammer, samt indhold og anvendelsesmuligheder af forskellige typer af tests til vurdering af ansøgeres kognitive evner og faglige potentiale for at kunne gennemføre og fuldføre en videregående uddannelse.

Vi vil afslutningsvis understrege, at udfoldelsen af de nye optagelsesprocedurer på Syddansk Universitet har et særligt fokus på at finde det rette match mellem den specifikke uddannelse og den studerende igennem tests og samtaler, der vurderer både evner og vilje for det specifikke studievalg. SDU-modellen har i denne kontekst en central funktion i forhold til at sikre, at de ansøgere, der vurderes, også besidder en indre drivkraft og motivation, der kan bære dem igennem et videregående uddannelsesforløb. Ansøgernes vilje til at møde op til en krævende test, samt deltagelse i fagspecifikke tests og samtaler, hvor deres personlige overvejelser og viden om uddannelsens relaterede indhold bringes i spil, vil således kunne afspejle såvel indre som ydre motivation for at vælge en specifik uddannelse.

Maria Cecilie Vonsild er uddannet cand. scient. og ansat som specialkonsulent i StudieserviceSekretariat. Maria er projektleder for implementering af de nye optagelsesprocedurer på Syddansk Universitet.

Agner Holmberg Schibler er uddannet cand.scient.pol og ansat som AC-fuldmægtig i Studieservice-Analyse på Syddansk Universitet.

Birgitta Wallstedt er uddannet cand.scient. og er ansat som kontorchef og leder af SDU Universitetspæedagogik på Syddansk Universitet.

\section{Litteratur}

Brownell, K., Lockyer, J., Collin, T. \& Lemay, J. F. (2007). Introduction to the multiple mini interview into the admissions process at the University of Calgary: Acceptability and feasibility. Medical Teacher, 29, 394-396.

Coates, H., Edwards, D. \& Friedman, T. (2010). Student aptitude test for tertiary admission (SATTA) pilot program. Evaluation report for the Department of Education, Employment and Workplace Relations (DEEWR). Australian Council for Educational Research.

Emery, J. L. \& Shannon, M. D. (2007). The predictive validity of the Thinking Skills Assessment: A combined analysis of the three cohorts. Admission Testing Service.

Eva, K. W., Rosenfeld, J., Reiter, I.H. \& Norman, G. R. (2004). An admissions OSCE: The multiple mini interview. Medical Education, 38, 314-326.

Eva, K. W., Reiter, I.H., Trinh, K., Wasi, P., Rosenfeld. J. \& Norman, G. R. (2009). Predictive validity of the multiple mini interview for selecting medical trainees. Medical Education, 43(8), 767-775.

Ferguson, E., Sanders, A., O'Hehir, F. \& James, D. (2000). Predictive validity of personal statements and the role of the five-factor model of personality in relation to medical training. Journal of Occupational and Organizational Psychology, 73(3), 321-344.

Harris, S. \& Owen, C. (2007). Discerning quality: Using the multiple mini interview in student selection for the Australian National University Medical School. Medical Education, 41(3), 234-241. 
Hecker , K., Donnon, T., Fuentealba, C., Hall, D., Illanes, O., Morck, D. W. \& Muelling, C. (2009). Assessment of applicants to the veterinary curriculum using a multiple mini-interview method. Journal of Veterinary Medical Education, 362), 166-173.

LeMay, J. F., Lockyer, J. M., Collin, V. T. \& Brownell, A. K. (2007). Assessment of noncognitive traits through the admissions multiple mini-interview. Medical Education, 41(6), 573-579.

O’Neill, L., Korsholm, L., Wallstedt, B., Eika, B. \& Hartvigsen, J. (2009). Generalizability of a composite student selection program. Medical Education, 43, 58-65.

Oosterveld, P. \& ten Cate, O. (2004). Generalizability of a study sample assessment procedure for entrance selection for medical school. Medical Teacher, 267), 635639.

Reiter, H. J., Eva, K.W., Rosenfeld, J. \& Norman, G. R. (2007). Multiple Mini Interview predict clerkship and licensing examination performance. Medical Education, 41(4), 378-384.

Roberts, C., Zoenetti, N. \& Rothnie, J. (2009). Validating a multiple mini-interview question bank assessing entry-level reasoning skills in candidates for graduateentry medicine and dentistry programmes. Medical Education, 43(4), 350-359.

Salvatori, P. (2001). Reliability and validity of admission tools used to select students for the health professions. Advances in Health Science Education: Theory and Practice, 62), 159-75.

Studieservice-Analyse, Syddansk Universitet. (2015). Dokumentation til evaluering af kvote 2 - proces. Intern rapport.

Styrelsen for Videregående Uddannelser (2015). Evaluering af optagelsessamtalerne på læreruddannelsen - optaget 2014. København: Styrelsen for Videregående Uddannelser, Uddannelses- og Forskningsministeriet.

Wouters, A., Bakker, A. H., van Wijk, I. J., Croiset, G. \& Kusurkar, R. A. (2014). A qualitative analysis of statements on motivation of applicants for medical school. BMC Medical Education,14, 1-11. 


\title{
Opgave- og skrivevejledning i klynger
}

\author{
Helle Merete Nordentoft, lektor ved Danmarks institut for Pæedagogik og \\ Uddannelse, Aarhus Universitet.
}

Hanne Nexø J ensen

Samfundslitteratur, 2015

128 sider

\section{ISBN 9788759319833}

Opgave- og skrivevejledning i klynger er en særdeles velkommen bog, da den griber ind i hjertet af de udfordringer, som kan udspille sig, når man vejleder kollektivt, og kommer med klare bud på, hvordan man kan vejlede i en klynge. Forskningen underbygger netop, at vejledning $\mathrm{i}$ et kollektivt forum er en udfordring for mange vejledere. En udfordring, som kan betyde to ting: 1) at de ikke påtager sig at vejlede i et kollektivt forum, og 2) når de gør det, udvikler "vejledningen" sig til mere at være en undervisningssituation end en vejledningssituation. Formålet med bogen er at konkretisere, hvordan undervisere og vejledere kan facilitere studerendes opgaveskriveproces i en klynge. Bogen er skrevet i et let tilgængeligt og flydende sprog og inddelt i 15 kapitler. Kapitel 1 er en introduktion til bogens indhold. Kapitel 2-4 uddyber de strukturelle og vejledningsmæssige rammer for skriveprocessen. Kapitel 5-12 følger på kronologisk vis skriveprocessen fra start til slut ift. de afsnit, som et eksamensprojekt bør indeholde. Endelig sammenfatter forfatteren de feedbackformer, som er beskrevet i bogens kapitler i kapitel 15.

Bogen spiller godt sammen med to andre centrale udgivelser ift. universitetspædagogik: Den gode opgave og den nyligt udkomne: Universitetspædagogik som en forenklet udgave af disse. Bogens styrke er klart, at den bevæger sig helt ind i skriveprocessens maskinrum og udfolder, hvad der er på spil. Fx illustrerer forfatteren, hvordan vejlederen kan vise de studerende, hvordan de kan arbejde med at undgå plagiat gennem den måde de citerer deres kilder på (s. 74). Forfatteren konkretiserer desuden et utal af måder, feedbackprocesser kan udfoldes på ift. den kontekst, vejlederen ønsker at bruge dem i.

Bogen er således relevant, men den er også udtryk for et ambitiøst projekt. Ifølge forfatteren skal den kunne fungere som en opslags-/håndbog, hvor kapitlerne kan læses hver for sig. I den forbindelse er det tanken, at de forskellige skematiske opsummeringer skal give vejlederen en oversigt, der er hurtig at gå til og at bruge, når han/hun skal vejlede den studerende igennem hele opgaveprocessen. Det er forfatterens tese, at undervisere og vejledere kan bidrage til at sikre en "effektiv" vejledning ved at "imødekomme studerendes vejledningsbehov gennem hele uddannelsen" (s. 10). Klyngevejledning kan desuden lære de studerende en processuel tænkning og gøre det muligt for dem "at skyde genvej til bedre opgaver" (s. 11).

Det er et dilemma på den ene side at skulle levere "effektiv undervisning" - hvad det så end betyder - og på den anden side at skulle være nuanceret pædagogisk og fagligt i de overvejelser, man gør sig som underviser og vejleder. I denne sammenhæng ser jeg, at bogens styrke samtidigt er dens svaghed: At væsentlige begrebsafklaringer og diskussioner er udeladt til fordel for en skematisering og forenkling af den kollektive vejlednings- 
og undervisningsproces. Fx uddybes det ikke særligt meget, hvordan ulemperne ved klyngevejledning, som skitseres på side 17, konkret kan spille ind og håndteres ift. de cases, som bogen præsenterer. Bogens læringsteoretiske afsæt understreger $\mathrm{fx}$, at deltagelse er en forudsætning for læring. Derfor ville det have været frugtbart med overvejelser ift., hvordan vejledere kan håndtere pædagogiske udfordringer ift. denne præmis, fx udfordringer med studerende, der stiller konfronterende spørgsmål, tavse studerende - eller studerende, som ikke bidrager aktivt til klyngens arbejde. Kapitlerne i bogen har karakter af at være opremsende gennem brugen af skemaer og kassemodeller ift., hvordan vejlederen/underviseren kan agere og facilitere læringsprocesser i en klynge. Et forhold, som forfatteren selv er opmærksom på og skriver, kan virke overvældende for nogle (s. 16).

Bogen rummer nogle begrebsmæssige uklarheder, som kan forvirre læseren ift. formålet med bogen. Fx er det ikke klart, hvad der karakteriserer en klynge til forskel fra fx en gruppe - og hvilken pædagogisk betydning det kan få. Desuden står der i kapitel 1 til forskel fra det, som bogens titel angiver, at bogen ikke kun tematiserer vejlednings- men også undervisningsforløb - uden dog at beskrive hvad forskellen er på undervisning og vejledning til trods for, at disse betegnelser bruges parallelt igennem hele bogen. Et introducerende kapitel kunne med fordel foretage disse begrebsmæssige afklaringer.

Der er eksempler på vejledning- og undervisning i klynger fra både humanistiske og naturvidenskabelig undervisningsområder. Disse eksempler forekommer rundt omkring $\mathrm{i}$ bogen uden, at der er en rød tråd i, hvornår hvilke eksempler bruges. Forfatteren har givetvis ønsket at vise, hvordan klyngeformen er en principiel undervisnings- og vejledningsform, som kan gå på tværs af fagfelter. Øvelsen er således at balancere det at få det principielle frem i klynge-vejledningsformen med det at vise, hvordan den konkret bruges i forskellige fagfelter. Sidstnæunte kan godt forvirre fokus ift. førstnæunte, da der er mange beskrivelser i en forholdsvis kort bog. Man kunne derfor have ønsket sig, at bogen havde benyttet to eksemplariske cases (en fra hvert hovedområde) ift., hvordan progressionen i klyngevejledningen kan udfoldes.

Når ovenstående er sagt, så har jeg allerede taget hul på flere af de anvisninger, som bogen giver ift. fx feedback i min egen undervisning og vejledning, og det har været meget givtigt. 


\title{
Dealing with emotions. A Pedagogical Chal- lenge to Innovative Learning
}

\author{
Camilla Schmidt, lektor, Institut for Mennesker og Teknologi, Roskilde \\ Universitet
}

Birthe Lund og Tatiana Chemi (Eds.)

Sense Publishers, 2015

136 sider

ISBN 978-94-6300-064-2

Bogen består af kapitler (eller separate artikler) med en indledning og afsluttende konklusion forfattet af redaktørerne, samt et såkaldt 'afterword' af en syvende forfatter. Bogen er skrevet på engelsk. Det erklærede formål med bogen er at adressere et tabu omkring at beskæftige sig med 'emotions' (følelser) i uddannelsessammenhænge. Forfatterne mener, at der i uddannelsessammenhæng er en manglende bevidsthed om, hvordan følelser integreres som en del af undervisningen i praksis, og hvordan følelser er på spil i uddannelse i bredere forstand. Gennem belysning af en række forskellige uddannelsesog undervisningsmæssige sammenhænge i grundskole, ungdomsuddannelse, videregående uddannelse og voksenuddannelse, nationalt og internationalt, diskuteres forståelser af følelser i uddannelse og læring.

Kapitlerne i bogen er alle forfattet af medlemmer af en forskningsgruppe ved Ålborg Universitet, som arbejder med at udvikle og udbrede viden om eksisterende læringskulturer og nye tendenser inden for uddannelse. Gruppen beskæftiger sig især med innovativ læring, kreativ læring, brugen af kunst i undervisningen, formelle og uformelle læringskulturer, evaluering og bedømmelse i grundskolen, problembaseret læring og projektarbejde i ungdomsuddannelser og udvikling af læringskulturer i videregående uddannelse og voksenuddannelse. Det er også inden for disse områder, kapitlerne i bogen tager deres afsæt i arbejdet med følelser i uddannelse, idet der argumenteres for, at sådanne læringskulturer i særlig grad gør det muligt at få øje på og arbejde med følelser.

Det er ikke klart, hvem målgruppen for bogen er. Forfatterne giver ikke selv noget bud på, hvem målgruppen kan være. Der lægges i stedet vægt på, at bogen har som mål at reflektere over, hvordan følelser viser sig, og hvilken betydning de kan have i uddannelse ud fra såvel teoretiske refleksioner som empiriske nedslag. Bogen henvender sig således nok bredt til undervisere og uddannelsesforskere med et budskab om at reflektere følelsesmæssige aspekter af undervisningen samt om at forholde sig til, hvordan der kan arbejdes med teoretiske perspektiver på følelser i uddannelser.

Alle kapitlerne i bogen er hver i sær interessante og leverer nogle tankevækkende analyser, som alle har at gøre med, hvordan følelser er på spil i uddannelsessammenhæenge. Det bliver dog aldrig helt klart, hvordan kapitlerne hænger sammen, og hvordan de refererer til hinanden. De har tydeligt afsæt i en interesse i læringskulturer, som også er forskningsgruppens erklærede interessefelt.

Som uddannelsesforsker læser jeg bogen som et forsøg på at stille skarpt på et aspekt af uddannelsesforskningen, som ellers ikke levnes megen plads - som forfatterne selv pointerer. En insisteren på, at uddannelsessammenhænge kan og skal belyses med blik for, hvad der følelsesmæssigt er på spil, finder jeg både spændende og vigtig. Bidragene $\mathrm{i}$ bogen handler om og diskuterer tilstedeværelsen af følelser på en ret forskellig og ikke 
alle steder lige vellykket måde. De empiriske nedslag synes velvalgte og relevante, og bliver bærende for diskussionerne (eller refleksionerne, som de selv siger).

Som underviser og uddannelsesansvarlig synes jeg bogen fremstår som et noget abstrakt bidrag til undervisningspraksis. Her får man ikke tilstrækkelig indsigt i de læringsmiljøer, som analyserne trækker på. Som praktiker er der derfor ikke så meget at hente til inspiration.

Konkluderende mener jeg, at indsatsen med at arbejde analytisk med tilstedeværelsen af følelser i læring, undervisning og uddannelsen er prisværdig. Som forfatterne selv siger, er dette arbejde et forsøg på at sætte sådant arbejde på dagsordenen og danne afsæt til at lave mere uddybende studier og analyser. Det er velkomment.

Bogen indeholder følgende kapitler:

The Notion of Emotion in Educational Settings When Learning to Become Innovative and Creative (Birthe Lund). I dette kapitel analyseres en gruppe gymnasieelevers følelses- og adfærdsmæssige reaktioner i forhold til den pædagogiske praksis i relation til rollespil med henblik på at udvikle innovative og kreative medborgere i Nordjylland. I kapitlet konkluderes det, at eleverne både oplever usikkerhed og stort engagement, når de mødes med det uforudsigelige i sådanne kreative og innovative processer. Det problematiseres at undervisning ofte tilrettelægges med henblik på at undgå sådanne usikkerheder og derfor også risikerer at forhindre udviklingen af engagement og kreativitet.

Emotions and Learning in Arts-Based Practices of Emotional I nnovation (Tatiana Chemi and J ulie Borup J ensen). Dette kapitel følger et forløb, hvor en gruppe undervisere på en professionshøjskole arbejder med at implementere kunst og æstetik som en del af deres undervisningspraksis. I analysen af denne proces skelnes der mellem negative og positive responser på arbejdet hos både undervisere og studerende. Kapitlet konkluderer, at kunst og æstetisk baseret undervisning gør det muligt at få øje på ellers skjulte lære- og erfaringsprocesser, både for studerende og undervisere. Undervisere synes i særlig grad at være sensitive i forhold til de studerendes (især) positive responser på undervisningen. Analysen peger fremad mod behovet for yderligere forskning i, hvordan følelser udtrykkes og modtages i læringsrum, hvor der arbejdes med kunstbaseret og æstetisk undervisningspraksis.

Gross National Happiness in Bhutanese Education (Lone Krogh and Krishna Prassad Giri). Dette kapitel diskuterer, hvordan man i Bhutan implementerer 'happiness' som et parameter for politisk og social vækst og dermed som et overordnet mål for landets uddannelsespolitik og praksis. Kapitlet rejser spørgsmålene, hvorvidt indførelse af 'Gross National Happiness' i sig selv skaber glæde, og om det i virkeligheden er for stor en udfordring for uddannelserne at implementere dette overordnede mål i alle fag. I kapitlet diskuteres det, hvordan man som uddannelser balancerer mellem kravet om at udvikle denne særlige nationale identitet baseret på harmoni og 'happiness', og kravet om at udvikle uddannelserne, så de lever op til globale mål og krav, som baseres på andre parametre og forståelser af vækst. Konklusionen er, at man med tilstrækkelig opmærksomhed på behovet for kontinuerligt at uddanne lærerne til at klare opgaven, godt kan opnå både 'happiness' og global vækst.

\footnotetext{
How Does It Feel to Become a Master's Student? Boundary Crossing and Emotions Related to Understanding a New Educational Context (Annie Aarup Jensen). I dette kapitel analyseres modne studerendes møde med en akademisk uddannelses- og læringskultur, når de påbegynder kandidatuddannelse efter endt professionsbacheloruddannelse og nogle års erhvervsaktivitet. Analysen af disse studerendes følelsesmæssige reaktioner på mødet med en akademisk læringskultur bygger på den obligatori-
} 
ske 'studieudviklingsplan', som dels består af en skriftlig rapport og dels af en dialog med en anden studerende. De skriftlige produkter viser, at de modne studerende er på hårdt følelsesmæssigt arbejde i mødet med den akademiske læringskultur. I kapitlet konkluderes det, at de ofte oplever det som om, de overlades til selv at skabe mening i overgangen, hvilket betyder, at de oplever det som et individuelt problem. Det skaber oplevelser af ensomhed og angst for at fejle. Det anbefales at der fokuseres på den institutionelle logik, som skaber denne oplevelse, og at der sættes ind med understøttelse af disse studerendes overgange i forhold til det institutionelle problem.

Emotions in the Classroom: The Powerful Role of Classroom Relationships (Sarah L. Grams and Roman J urowetzki). I dette kapitel præsenteres et surveybaseret studie af sammenhængen mellem læringsglæden og elev-lærerrelationen hos tyske elever i alderen 10-13 år. Hypotesen bag undersøgelsen er, at der er en sammenhæng mellem elevernes oplevede glæde ved læring og deres oplevelse af en positiv elev-lærerrelation. Denne hypotese bekræftes i undersøgelsen, idet det slås fast, at læreren har en signifikant betydning for etableringen af et gunstigt læringsmiljø og for elevernes læringsudbytte. Det slås fast, at det er ønskeligt, at der rettes større opmærksomhed mod etableringen af socialt og følelsesmæssigt understøttende læringsmiljøer.

A Comparative Study of Students' Perceptions of Humor in Learning Creative Design between China and Denmark (Chunfang Zhou, Tatiana Chemi and Birthe Lund). Studiet, som præsenteres i dette kapitel, er et komparativt studie af studerendes brug og opfattelse af humor i gruppearbejde på uddannelser i industrielt design i henholdsvis Kina og Danmark. Studiet baserer sig på kvalitative interviews med studerende, som er involveret i gruppearbejde omkring deres uddannelse - i Danmark er det gruppearbejde, som er en del af den pædagogiske metode, i Kina er gruppearbejdet især relateret til samarbejder med eksterne virksomheder og organisationer. Studiet konkluderer, at når studerende i begge lande er positivt stemte i forhold til deres kreative arbejde, kommer det til udtryk i form af humor. Dog er der den forskel, at når danske studerende benytter humor, ser de det som en væsentlig del af den kreative proces, mens de kinesiske studerende opfatter humor som et redskab til at skabe gode individuelle relationer ind i gruppen. Analysen peger på, at vejledere generelt set skal være mere opmærksomme på brugen af humor i gruppearbejde. I Kina bør vejledere være mere understøttende i forhold til at etablere en humoristisk atmosfære i grupperne, da humoren betragtes som en grundpille i designeres sociale identitet og i udviklingen af en kreativ industri. 


\title{
Eksamensangst. Et problem vi skal løse i fæl- lesskab
}

\author{
Jens Tofteskov, chefkonsulent, CBS Teaching and Learning, Copenhagen \\ Business School
}

Helle Hvass (red.)

Samfundslitteratur, 2015

179 sider

\section{ISBN 9788759319284}

Et af de hyppigst forekommende spørgsmål på vores eksamenskurser for undervisere på CBS er: Hvad gør vi, når en studerende ikke kan sige noget, fordi han/hun græder eller har åndenød? Med andre ord hvad gør man her og nu i en situation, hvor eksamensangst optræder med en styrke, der meget klart er voldsomt hæmmende for den studerendes præstation? Her ved vintereksamen har jeg som intern censor ved en mundtlig eksamen i Videnskabsteori oplevet eksamensangst i voldsommere udgaver og i flere tilfælde, end jeg har gjort før. Til gengæld synes jeg ikke, jeg har rigtig gode svar til kursister eller sikre handlemåder, der kan håndtere studerende, der er plaget af angst. Der er derfor for mig ingen tvivl om, at en bog om eksamensangst kan falde på et meget tørt sted.

I bogen får jeg i flere kapitler svar på hvordan eksamensangst kan forebygges i rammesætningen af undervisningen og i selve undervisningen. Jeg får nogle svar på, hvorfor eksamensangst opstår både som et samfundsmæssigt eksploderende fænomen og som et fænomen, der optræder hos den enkelte, og jeg får at vide, hvordan angsten hænger sammen med, hvordan vores hjerne fungerer. J eg får svar på hvordan bestemte eksamensformer producerer særlige angstformer, og jeg får viden om, hvordan angsten ytrer sig på forskellige tidspunkter i en eksamensproces. J eg får også nogle svar på, hvordan man ud fra forskellige terapeutiske tiltag kan behandle eksamensangst. Men jeg får ikke svaret på vores eksamenskursisters spørgsmål: Hvad gør jeg, når den studerende begynder at græde?

Det kapitel, der kommer tættest på denne problematik, er J ette Barnholdt Hansens: "Eksaminator ved mundtlig eksamen". I mplicit indeholder kapitlet en tro på en spejlingseffekt. Altså, når jeg som eksaminator udviser ro i min krop, i min stemme, i min mimik m.m., så forplanter det sig til den studerende. Når jeg skriver, at kapitlet implicit indeholder denne forestilling, er det fordi, der er en del råd til, hvordan man som eksaminator kan arbejde med disse ting. Gennem erfaring er jeg bestemt blevet overbevist om, at denne spejlingseffekt virker $i$ langt de fleste tilfælde. Som underviser er det $i$ det hele taget godt at arbejde med krop, bevægelser, tale og stemme, og de kompetencer, der her udvikles, kan i den grad bruges ved mundtlig eksamen. Der er også en række råd til, hvordan man som eksaminator kan arbejde med studerende, der udviser en angst, som hæmmer deres eksamenspræstation ved fx at tale for hurtigt. 
En del af kapitlerne indeholder fine betragtninger over, hvordan man som underviser kan forebygge eksamensangst. Her vil jeg mene, at Berit Lassesens kapitel er meget vigtigt: "Hvordan kan eksaminatorer modvirke eksamensangst gennem deres måde at undervise på?" Det er dybest set en opfordring til at tage såvel alignment som dybdelæring alvorligt. Alignment handler om at skabe overensstemmelse mellem undervisning og eksamen, således at undervisningen fungerer som en træning til at gennemføre eksamen. Dybdelæring handler om at skabe indsigt i faget på højere kognitive niveauer. Kombinationen alignment og dybdelæring kan sikre, at eksamen netop ikke bliver den tilfældige test af overfladeviden, der kan bidrage til at udvikle og forstærke eksamensangst. Det handler om at skabe en forståelse blandt de studerende for, hvorfor undervisningens indhold og form bidrager til, at de studerende bliver i stand til at håndtere eksamenskravene. Derved skabes en tryghed, der kan hæmme udviklingen af eksamensangst.

I bogen behandles både sociologiske og psykologiske/biologiske forklaringer på opståen af eksamensangst. Med udgangspunkt i 'konkurrencestaten' har Camilla Hutters og Niels Ulrik Sørensen skrevet kapitlet "Eksamensangst - et voksende problem i konkurrencesamfundet". Her er fortællingen om alle ulykkerne, der lige nu strammer til: perfektionismen, selvfremstillingen, forventningspresset og det globale uddannelseskapløb, der ødelægger barndom og ungdom. Det er næsten uudholdeligt at læse sig igennem, og jeg, som er årgang 52, kommer midt i al elendigheden til at tænke på, at den skole jeg gik på, var en tæskefabrik, så mon det hele er værre i dag? Ja, det er i hvert fald anderledes, og jeg ville nødig bytte min barndoms/ungdoms smældende skolelussinger ud med konkurrencen om Facebook-likes, testhelvedet, heldagsskole, tolvtalsambitioner og fremdriftsreform. Så på trods af, at det langt fra er underholdende at gennemtygge den type læsning, synes jeg, at det både er prisværdigt og nødvendigt at forklare, at den stigende eksamensangst har særdeles gode vækstbetingelser i konkurrencesamfundet.

I Raben Rosenbergs kapitel - "Hvad sker der i hjernen ved eksamensangst" - er der forklaringer af angsten som fænomen, af forskellige angstformer, at angst er nødvendig for vores overlevelse, og at angsten først bliver et problem, når den bliver sygelig. Raben Rosenberg skriver, at eksamensangst er en normal reaktion hos det moderne menneske, men hos nogle mennesker kommer angsten til at fylde så meget, at det bliver en psykisk lidelse og nedsætter dette menneskes livskvalitet. En god eksamenspræstation er nærmest betinget af en mindre portion angst. Dette kapitel forøger dermed relevansen af nogle af bogens andre kapitler, der handler om, at eksaminator og censor i eksamenssituationen gennem deres adfærd bør optræde angstdæmpende, så den moderate og konstruktive angst, det store flertal af eksaminander bærer med sig til det grønne bord, ikke undervejs udvikler sig til noget, der er destruerende.

Den terapeutiske behandling af (permanent, sygelig) eksamensangst tages bl.a. op i Tine og Poul Baiers kapitel: "Eksamensangst som personlig krise - hvorfor virker coaching". Coachingteknikken går ud på at flytte fokus fra den præstationsangst, der er forbundet med eksamen til personens styrker og ressourcer. Der er en række gode eksempler på hvilke spørgsmål, der kan bidrage til at flytte dette fokus.

Jeg har ikke taget alle bogens temaer og alle bogens kapitler op i denne anmeldelse. Som helhed er bogen velskrevet og velredigeret. Det betyder først og fremmest, at når et tema berøres, som behandles dybere $\mathrm{i}$ et andet kapitel, er bogen rigt forsynet med 
krydshenvisninger. Det er en meget bredtfavnende bog. Af bagsideteksten fremgår det: Målgruppen er undervisere, studievejledere, studenterrådgivere, mentorer, eksaminatorer, opgavevejledere, censorer og andre på mellemlange og lange videregående uddannelser, som skal hjælpe studerende, der har eksamensangst. Dette er selvsagt en meget omfattende målgruppe, og bogens indhold bærer præg af denne bredde. Derfor kommen bogen heller ikke for alvor i dybden, og det har næppe heller været hensigten. Der er tale om en bog der skaber overblik over et aktuelt og påtrængende tema. 


\section{DANSK UNIVERSITETSPAEDAGOGISK TIDSSKRIFT}

\section{Årgang 11 Nummer 20/2016}

Titel: Kvalitet i universitetsundervisningen - forskningsbasering, praksisrelevans og strategisk indsats

Sponsoreres af Dansk Universitetspædagogisk Netværk

REDAKTION

Kim J esper Herrmann, Center for Undervisning og Læring (AU) (ansvarshavende)

Bo Skøtt, Institut for Design og Kommunikation (SDU)

J ulie Borup J ensen, Institut for Læring og Filosofi (AAU)

Lotte Rienecker, Institut for Naturfagenes Didaktik (KU)

Michael Pedersen, Institut for Psykologi og Uddannelsesforskning (RUC)

Sofie Kobayashi, Institut for Naturfagenes Didaktik (KU) 